\title{
UTMARK
}

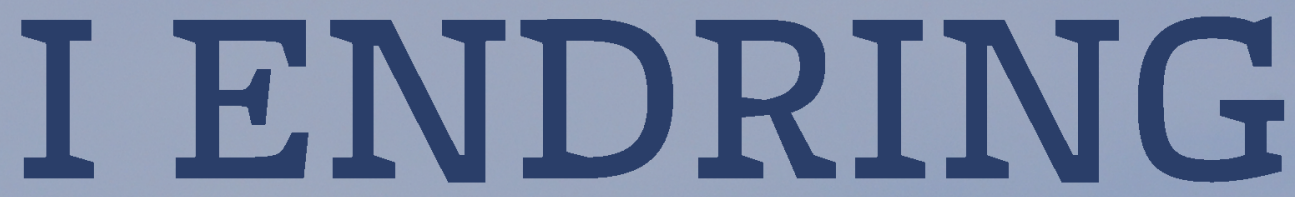

Frode Flemsæter og Bjørn Egil Flø (red.)

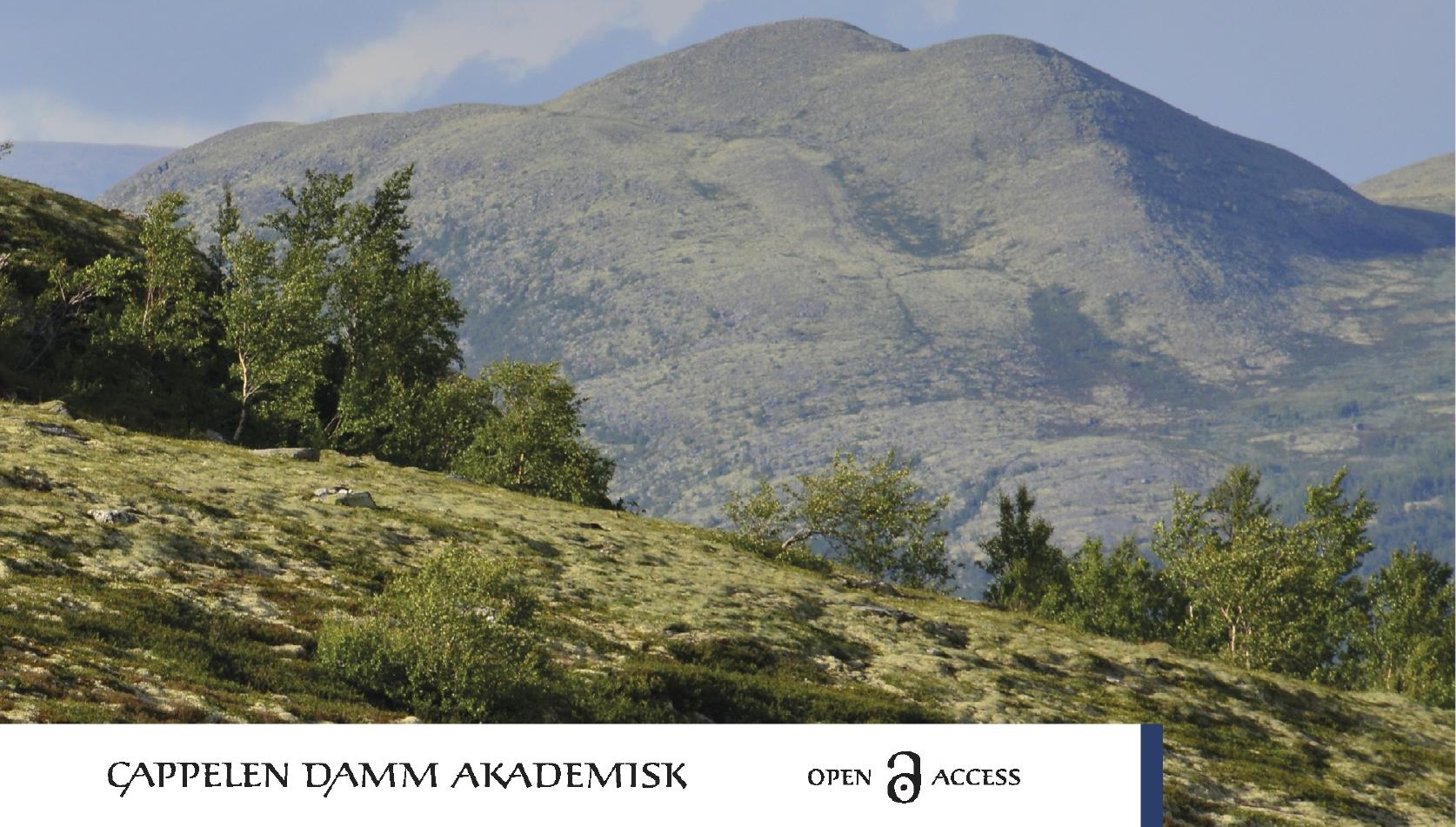


Utmark i endring 

Frode Flemsæter og Bjørn Egil Flø (red.)

\section{Utmark i endring}

CAPPELEN DAMM AKADEMISK 
(C) 2021 Tor Arnesen, Katrina Myrvang Brown, Svein Morten Eilertsen, Knut Fageraas, Frode Flemsæter, Bjørn Egil Flø, Katrine Broch Hauge, Bernt Johansen, Stine Kvamme, Jan Åge Riseth, May Thorseth, Odd Inge Vistad og Jørund Aasetre.

Dette verket omfattes av bestemmelsene i Lov om opphavsretten til åndsverk m.v. av 1961. Verket utgis Open Access under betingelsene i Creative Commons-lisensen CC BY-NC-ND 4.o. Denne lisensen lar andre kopiere, distribuere og spre verket i hvilket som helst medium eller format, under forutsetning av at det oppgis korrekt kreditering og lenke til lisens. Dette kan gjøres på enhver rimelig måte, men uten at det kan forstås slik at lisensgiver bifaller deg eller din bruk av verket. Materialet kan ikke benyttes til kommersielle formål. Dersom du remixer, bearbeider eller bygger på materialet, kan du ikke distribuere det endrede materialet.

Lisensvilkår: https://creativecommons.org/licenses/by-nc-nd/4.o/deed.no

Boka er utgitt med støtte fra Norges forskningsråd, Nibio - Norsk institutt for bio$ø$ konomi og Ruralis - Institutt for rural- og regionalforskning.

ISBN trykt bok: 978-82-02-74936-1

ISBN PDF: 978-82-02-66963-8

ISBN EPUB: 978-82-02-74933-O

ISBN HTML: 978-82-02-74934-7

ISBN XML: 978-82-02-74935-4

DOI: https://doi.org/10.23865/noasp.151

Dette er en fagfellevurdert antologi.

Omslagsdesign: Cappelen Damm AS

Omslagsfoto: Anders Bryn

Cappelen Damm Akademisk/NOASP

noasp@cappelendamm.no 


\section{Innhold}

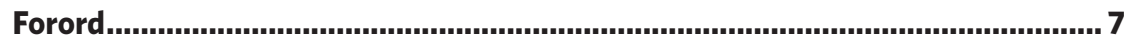

Kapittel 1 Utmark i endring - når nye tider gir andre tilhøve......................... 9 Bjørn Egil Flø og Frode Flemsæter

Kapittel 2 Reindriftas sårbarhet og Norges ansvar. 29

Jan Åge Riseth, Svein Morten Eilertsen og Bernt Johansen

Kapittel 3 Mot ei framtid for utmarksbeite - om beiting, sjølvkjensle og forståing mellom folk

Bjørn Egil Flø

Kapittel 4 Kampen om utmarka: Hytter, beitemark eller urørt natur?

Jørund Aasetre

Kapittel 5 Fritidsbygg i fjellområdet - en egen boligstruktur? 123

Tor Arnesen og Stine Kvamme

Kapittel 6 Rettslege rammer for klimavenleg energiproduksjon i utmarka: Utfordrar klimaomsynet legitimiteten til konsesjonsregelverket? 151

Katrine Broch Hauge

Kapittel 7 Menneske og dyr i grenseland - om rettar, rettferd og rett ferd $\mathrm{i}$ utmarka. 191

Frode Flemsæter og Katrina M. Brown

Kapittel 8 Rovviltforvaltning og reindriftsnæringen: Hvordan kan en todelt målsetting praktiseres i samsvar med internasjonale konvensjoner? 213

Svein Morten Eilertsen og Jan Åge Riseth

Kapittel 9 Stien i endring? Om det godes paradoks 239

Odd Inge Vistad 
Kapittel 10 Har utmarka blitt historie? ..........................................................265

Knut Fageraas

Kapittel 11 Utmarksetikk i endring? ..................................................................285

May Thorseth

Bidragsytarar...........................................................................................................307 


\section{Forord}

Utmarka er eit sær-skandinavisk omgrep, som vitnar om stadeigne kjenneteikn ved det fysiske så vel som det mentale landskapet. I tusenvis av år har utmarka vorte sett på som ein utvida del av gardsbruka, og den har inngått som ein viktig del av bondehushaldet sin økonomi. Men «tida og tilhøva» - som det står i fjellova - endrar seg. Bondefamiliane er færre, og landbruket, så vel som andre brukarar, ser på utmarka med andre auge, noko som skaper nye utfordringar som verken dei kulturelle eller institusjonelle omgjevnadane nødvendigvis er skodd for å handtere.

Dette var bakgrunnen for at Ruralis - Institutt for rural- og regionalforsking og Nibio - Norsk institutt for bioøkonomi samla ei rekkje sentrale norske utmarksforskarar i eit nettverksprosjekt, der ei uttalt målsetting var «å føre forsking, forvaltning, industri og brukarar tett saman for bærekraftig innovasjon i utmarka». Dette vart gjort gjennom å arrangere ein serie med opne fagseminar i ulike delar av landet, der vi inviterte til samtalar om tida og tilhøva i utmarka. Brukarar, forvaltarar, forskarar og folk flest møttest for å drøfte aktuelle og sentrale tema som beiteproblematikk, industriutbygging, natur- og kulturmangfald og rekreasjon.

Som ein del av dette nettverksarbeidet, og ikkje minst inspirert av desse fagseminara, sette vi oss eit mål om å lage ei bok om tida og tilhøva i utmarka, der det skulle bli lagt vekt på eit lett og tilgjengeleg språk samstundes som akademiske krav vart oppfylt. Her er resultatet.

Utvalet av tema i denne boka representerer forfattarane sine forskingsinteresser og forskingsprosjekt. Det er relevante tema, og det er interessante tema. Samstundes representerer dei ikkje alt som går føre seg og set sitt preg på tida og tilhøva i utmarka. Men mange av kapitla diskuterer prinsipielle og overordna spørsmål som har relevans langt ut over den konkrete tematikken som kapitla tek utgangspunkt i. 
Vi håpar og trur at boka vil vere interessant lesing for alle med interesse for bruk og forvaltning av utmarka. Dette kan vere studentar, forskarar, næringsaktørar eller forvaltarar av utmarka, men ikkje minst håpar vi at boka òg vil ha eit innhald og eit språk som gjer den interessant og leseverdig for den jamne samfunnsengasjerte ålmenta.

Vi vil rette ein takk til Noregs forskingsråd, som har finansiert arbeidet, til deltakarane i nettverket, og dermed forfattarane av kapitla i boka, til Cappelen Damm Akademisk som har teke på seg arbeidet med å gi ut boka, til dei anonyme fagfellane som har sikra den vitskaplege kvaliteten på bidraga, og til Ruralis og Nibio, som har gitt oss redaktørane rom til å gjennomføre arbeidet med å sette saman boka.

Trondheim, 15. oktober 2021

Bjørn Egil Flø (Nibio) og Frode Flemsæter (Ruralis) 


\section{Utmark i endring - når nye tider gir andre tilhøve}

\section{Bjørn Egil Flø}

Norsk institutt for bioøkonomi (NIBIO)

Frode Flemsæter

Ruralis - Institutt for rural og regionalforsking

«Du les deg heimatt» er eit uttrykk ein typisk kan høyre eit stykke nord på Vestlandet. Og me gjer nok det, begge oss to. Alt med etternamna våre - Flø og Flemsæter - fortel me kvar me har opphavet vårt. Og kanskje liknar me begge også litt på fedrane eller mødrene våre, i ganglaget, humoren eller i lynnet og måtar å vere på, slik at folk som kjenner opphavet vårt, ser att trekk i oss som dei kjenner frå dei før oss. Me ser det nok ikkje like godt sjølve som andre, men det har sett seg i oss som eit prent frå barne- og ungdomsåra som ingen av oss har ønskt å viske ut. Det er restar frå eit liv på ein stad som me enno kallar heime, ein stad me no vitjar fysisk berre i feriar og nokre langhelger innimellom, men som me ofte dett innom i tankar utan heilt å vite om det.

Kvifor startar me slik i eit introduksjonskapittel til ei bok om Utmark $i$ endring? Jau, me gjer det for å peike i retning av at våre små biografiske forteljingar på mange måtar reflekterer mykje av grunnlaget for dei endringane som me ser skjer i utmarka. Jamt fleire av oss flyttar ut frå der me vaks opp, me reiser frå ein stad til ein annan, og somtid reiser 
nokre også attende til der dei kom ifrå. Men dei fleste av oss reiser frå små lokalsamfunn til større samfunn - frå bygder til byar - me utvidar vårt sosiale nettverk og klatrar i sosiale klassestigar. Det gjer me på bygdene, like som i byane. Me går frå det David Goodhart (2017) kallar somewheres til anywheres, frå det Tomas Hylland Eriksen (2004) så elegant formulerer som det å ha røtter til det å ha føtter. Me går frå å orientere oss lokalt til å orientere oss globalt, me går frå det provinsielle til det kosmopolitiske. Me går frå det tradisjonelle via det moderne til det individualiserte post-moderne samfunnet (Beck \& Beck-Gernsheim, 2002; Beck et al., 1994; Benjaminsen \& Svarstad, 2008). Kanskje er me her heime omlag der britane var på 1990-talet, kanskje er me der at me er i ferd med å skape det post-rurale samfunnet (Murdoch \& Pratt, 1993). Eit samfunn der det rurale - rural kultur, tradisjonar og verdiar - taper posisjon i det offentlege ordskiftet om samfunnsutviklinga til fordel for dei urbane og meir individualistisk orienterte verdiane. Om det var moderniseringa som skapte individualiseringa, eller om individualiseringa var ein føresetnad for moderniseringa, er vanskeleg å seie, men det kan uansett sjå ut som det følgjast åt. Og saman går me frå det kollektivistiske til det individualistiske.

Flø og Flemma er begge jordbruksbygder, som i kombinasjon med fiske har merkt oss med meir enn einast etternamna, dei har også merkt oss med sosiale og kulturelle koder for korleis me ter oss i høve til kvarandre, og dei har merkt oss med ei rytme. Ei rytme knytt til årstider og gjeremål, ei sosial rytme av kulturelle normer tett knytt opp til ein stadeigen tradisjon for kva som er brukeleg - altså for korleis me brukar gjere ting her. I minna våre set opplevingane knytt til småbrukarens gjentekne årlege aktivitetar, arbeidsoppgåver som sette seg som kroppsleggjorde kollektive ritar i oss. Når torsken på ny seig ut att i havet, var det tid for lamminga og vårarbeidet på markane. Gjerder og utgardar trong vøling etter vinterens herjingar, ${ }^{1}$ og ofte var det kjærkome arbeid framfor å måtte stå bøygd over steinplukkinga på eit fornya attlegg.

$1 \quad$ Utgard har mange ulike dialektale nemningar kring om i landet og referer til gjerdet som skil utmark frå innmark. I dei fleste bygdelaga var det frå gamalt av vanleg at vølinga - altså vedlikehaldet - av utgarden var organisert som ein dugnad der dei fleste gardsbruka stilte med folk. 
Alt dette utgjorde den stadeigne kulturen i praksis og danna rammene for ei felles og til dels kroppsleggjort forståing av kven me var. Her lærte me kodene og veremåten som danna grunnlaget for lokalsamfunnet som eit sosialt system.

\section{Frå lokalsamfunnsgode til kollektiv identitet}

Men lokalsamfunnet, så vel som samfunnet elles, har endra seg mykje sidan me begge vaks opp høvesvis på Flø og i Flemma. Då var det stort sett lokalsamfunnet som var både brukarane så vel som forvaltarane av utmarkas herlegdomar, eller lunnende, som dei heiter så vakkert i fjellova. Og slik hadde det vore i fleire tusen år - så lenge me har hatt landbruk og bufaste bønder i dette landet. Utmarka var ein utvida del av gardsbruka, den var ei forlenging av innmarka. Og den var fyrst og fremst mark og ikkje fjell, for fjellet ... kven hadde då der noko å gjere? Fjellet var for mange bygdefolk - ikkje for alle, men for mange - som for «Kona frå Stavsbuøy», som Aasmund Olavson Vinje skildrar i sine ferdaminne frå 1860. "Du seier Ronden er fager du, [...] nei, stygg er han som den vonde sjølv [...] her (er) mest ikkje verande til for folk men troll» (Vinje, 1861). Utmarka var dei agrare grendenes gratis fellesressurs. Og folk samarbeidde, det beste dei kunne, om bruken og forvaltinga av den. Det har nok neppe vore berre harmonisk, dette samarbeidet. Les me dei gamle lovtekstene våre - som mellom anna Magnus Lagabøters landslov frå 1274 og Christian IVs Norske Lov av 1604 - så finn me at utmarka har vore vigd betydeleg merksemd. Her er rettar og plikter knytt til utmarksbruken detaljert skildra, noko som vitnar om at den ikkje berre har vore viktig for folk, men også at den har vore opphavet til mykje konflikt.

Samstundes ser me også at utmarka har spelt ei viktig rolle i forminga av kven me er og kven me meiner å vere (Daugstad et al., 2006). Då me nordmenn skulle finne oss sjølv, etter at både danskar og svenskar hadde herja med oss ei tid, vart utmarka viktig. Utmarka og fjellandbruket vart viktige symbol i bygginga av norskdomen. Då gjekk dei så langt dei orka, ut av Christiania på leit etter det norske. Dei måla og dikta om det dei såg, og skapte ideen om den staute nordmannen, sterkt 
prega av naturens brutalitet og estetikk. Nordmannen fanst der mellom bakkar og berg, han var om lag like fóret og vêrbiten som landet, og han drøymde seg attende til fjella og dalane han mintest frå ungdomen.

I utlandet Tyskland vart norske kunstnarar lagt merke til. Deira nasjonalromantiske skildringar fortalte om noko dei meinte å ha mista på kontinentet (Vinge \& Flø, 2012, 2015). Og landet vaks fram som noko unikt i europeisk forstand. Her oppe var folk enno jorda, dei levde tett på og i naturen. Me var mesta som naturmenneske å rekne, sett frå kontinentet. Og me trudde på det sjølve òg. Me meinte at naturen gjorde oss godt, for ikkje å seie gode.

\section{Moderniteten og den nye hamen}

Men med moderniteten kom vegane, bilane og fritida til Noreg. Fleire av våre tidlegare jordbruksgrender fekk industri, den festa seg under fossane og ved elvefara som gav folket og grendene grunnressursen dei trong. Vasskrafta og den vassborne råvara danna grunnlaget for ein industrivekst me lenge ikkje ante omfanget av. Bygdefolket kunne no sparke av seg fjøsstøvlane og ta på seg dongerikjeledressane og stille seg ved sagene og ved smelteomnane til faste tider.

Den Oppdal-baserte forfattaren og historikaren Inge Krokann (1942/1982) nytta omgrepet «det store hamskiftet» for å skildre dei omfattande økonomiske og kulturelle omveltingane det norske bondesamfunnet gjekk igjennom rundt midten på 180o-talet. Dei nye vegane hjelpte ikkje einast industrien, også bøndene fekk lettare og raskare tilgang til den jamt veksande marknaden. Det marknadsdrivne salsjordbruket og den teknologidrivne effektiviseringa (fyrst og fremst representert med hesten), mogleggjort gjennom utskiftinga og om-arrondering av jordbruksarealet til å passe betre den nye teknologien, var viktige faktorar som dreiv fram omveltingane (Nerbøvik, 1999). Også fiskeriet fekk sitt «hamskifte» denne tida. Frå fyrst på 190o-talet vaks storleiken på båtane langs vestlandskysten. Frå Nordmøre og sørover, der dei sjølveigande fiskarane lenge hadde vore fri frå væreigaråket, gjekk småbåteigarane saman og bygde seg felles båtar med eksplosjonsmotorar (Fulsås, 1996). Slik kunne dei nå lenger med mindre mannskap. Og på land «beita» motor- og 
reparasjonsverkstadane på den blomstrande fiskerinæringa, og slik feste den mekaniske industrien seg på øyar og nes langs norskekysten.

Industristadane vart viktige nodar i den nye pengebaserte varemarknaden, men industriarbeidarane skulle ikkje berre ha varer, dei hadde også behov for tenester og sørvis. Private så vel som offentlege tenestetilbydarar vaks fram, og gradvis vart kommunesentera til tettstadar med tydeleg småbypreg der bygdefolket frå grendene kring også kunne nå tak i gode som følgde med moderniseringa.

Mot slutten på 1950-talet og fyrst på 1960-talet tok altså landet for alvor steget inn i ein forbruksdriven økonomi. Me fekk det andre hamskiftet (Almås, 1977) då traktoren skifta ut hesten på gardane og folk flest fekk fleire timar i døgnet som dei kunne fylle med andre aktivitetar. Aktivitetar som før einast var for adel og fritenkjarar på kunstnarstipend, vart no gradvis folkeaktivitetar.

Sentrale arbeidarpartiprofilar gjorde det til ein dyd å gå i fotspora åt kultureliten som hadde måla og dikta så levande under nasjonsbygginga. Tydeleg fronta av landsfader Gerhardsen vart den nye eliten aktive brukarar av utmarka og det landlege for rekreasjon. Men enno var det det såkalla enkle friluftslivet som talde. Med beksaumstøvlar og Bergans-meis gjekk arbeidarklassa inn i nikkersen og let seg portrettere med tilsynelatande matnyttige reiskapar som bærplukkarar, markstong og ei og anna enkelløpa sovjetisk hagle frå Star Baikal i nevane.

Mange fekk etter kvart også ei jamt større interesse for å finne sin eigen stad. Dei ville ha sin plass i fjellet og ved fjordane, der dei kunne dyrke sin kjærleik til naturen og det landlege. Framover på 1970-talet kunne me sjå at naust, sjøbuer og stølshus fekk gardiner i vindauga, noko som vitna om ny bruk. Å setre gjaldt då ikkje lenger likevel, for no skulle dyra stå på bås heile året, og den som enno dreiv og sleppte storfe i utmarka, var mesta som reaksjonære å rekne, sett frå landbruksdepartementets korridorar.

\section{Den moderne utmarka}

Det var i dette tidsbiletet me begge vaks opp, på 1970- og 1980-talets rurale Nordvestland, og kvar på vårt heimlege småbruk. I vår tid var 
ikkje bygdefolk sitt forhold til fjellet lenger berre slik Vinje skildrar det gjennom forteljinga om «Kona frå Stavsbuøy». Nei, i vår tid hadde samfunnet gått igjennom moderniseringa. Tida og tilhøva, som det heiter i fjellova, var endra. No gjekk sjølv bygdefolk på fjellet berre for å gå. Dei gjekk ikkje til Skinnalidvatnet for å drage matfisk eller på Søkkjemyra for å hente heim moltebær, anna enn dei gjekk dit også for turen sin del aleine. Dei gjekk på toppane - på Skolma og Skorvå - einast for å nyte utsikta og for å la tankane fare. Men ingen av dei, og heller ikkje me, var meir framande for utmarkas agrare bruk enn at me visste at me ikkje skulle gå med bikkja ved foten mellom ku og kalv, i alle fall visste me kva risiko det kunne innebere. Me visste kva «kvast» i fôret var, at det var eit uttrykk for små kvasse gjenstandar - typisk av ein blikkboks som hadde vorte finkutta i fôrhaustaren - som husdyra kunne risikere å ete i seg og ende opp med store smerter og rift i matrøyret og nettmagen slik at nødslakt var einaste løysing. Me visste å late att leda etter oss når me gjekk gjennom utgardane. Og skulle det slumpe til at me gløymde oss ein gong og nokre sauer slapp igjennom utgarden, ja då fekk me høyre det på bygda, der alle undra seg på kva for «rakkar» som kunne vere så «likesæl». For sjølv om me vaks opp midt i ei endringstid for utmarka, sjølv om me vaks opp i ei tid då utmarka ikkje lenger berre var ein utvida del av jordbruket, men like mykje ein utvida del av livet åt oss alle i Flemma så vel som på Flø, så kjente me dei stadeigne reglane og kodane for korleis me skulle te oss.

Likevel, så gjorde også me oss gjeldande for den nye utmarka, både gjennom vår eigen bruk og gjennom våre eigne interesser. For gjennom heile etterkrigstida har det vore ein jamn vekst i det me kan kalle diversifiseringa av bruken av utmarka og dei rurale grendene. Ikkje berre har brukarane blitt meir ulike kvarandre, med vidare interesser og idear om kva utmarka er og kva den skal vere, men bruken har også teke fleire og andre former (Flø, 2012, 2013b, 2018). For det var ikkje berre beiting, hausting og anna nyttebruk som stod i fokus aleine lenger, ein jamt større del av brukarane - frå bygdene så vel som frå byane - søkte seg no til utmarka for rein rekreasjon og oppleving aleine.

Reiser du til Flemma i dag og ønskjer å kome i kontakt med folk, så finn du dei ikkje på den lokale butikken, den er uansett nedlagt for fleire 
år sidan. Derimot skal du ta deg ein tur til Flemsetervatnet. Gå ein tur rundt vatnet, her har lokalbefolkninga utbetra stien og gjort den farbar også for folk som kanskje ikkje er like gode til beins som dei ein gong var. Du kan raste på ein av dei mange rasteplassane og snakke med folk som kjem forbi, for det er her bygdefolket møtast no. Her finn dei det dei har mista oppgjennom åra, her pleier dei det same samhaldet som dei før pleidde då dei stod skulder ved skulder og vølte utgard. No er det stien og rasteplassane dei vøler, og når vølinga er gjort, går dei sine turar og treffer kvarandre for ein prat om laust og fast. I heile landet kan me sjå at den nære utmarka er i ferd med å bli dei nye lokale møteplassane. Like eins er det om du kjem til Flø. Der kan du gå utover Gotane og sjå dei gamle sumarføøsane på rekkje langsetter det forsølte ${ }^{2}$ landskapet mellom storhavet og fjellfoten. Dei er tomme no, sumarføsane, og det som før var viktige sumarbeiteområde for mjølkekyr, er no blitt den nye møteplassen for lokalsamfunnet. Men til forskjell frå området kring Flemsetervatnet ser me at på Flø oppstår det utfordringar når rekreasjonsbruken møter det moderne landbruket. Traktorane åt bøndene så vel som bilane åt dei rekreerande gjestane er større, farten har auka, og graslassa er tyngre. Somtid skjer det at gjestane har parkert slik at bonden ikkje kjem forbi med traktor og reiskap. Samstundes har kanskje heller ikkje landbruket lenger den same posisjonen hjå folket som går langs driftsvegen utover Gotane, som det ein gong hadde. Det kan synast som ikkje alle lenger har den same omsuta og forståinga for korleis ein som fritidsbrukar skal te seg overfor yrkesbrukarane.

\section{Kommodifisering}

Det har skjedd det samfunnsforskarane kallar ei kommodifisering av det agrare landskapet og kanskje særleg av utmarka. Med det meiner ein at jordbrukslandskapet så vel som utmarka har blitt gjort om til ei vare

2 For den som ikkje kjenner ordet «forsølt», kan me fortelje at det er eit uttrykk som skildrar område som ligg slik til at det får mindre sol enn andre områder. Typisk tronge fjordar eller dalar som ligg slik at fjella skuggar for sola i mange timar om dagen. 
i seg sjølv og ikkje berre eit landskap der ein produserer varer. Denne kommodifiseringa skaut fart då Lars Sponheim sette seg i sjefsstolen for Landbruks- og matdepartementet i oktober 2001. Han arva ei landbruksmelding ${ }^{3}$ som neppe kunne ha vore betre tilpassa ein landbruksøkonomiutdanna Venstre-statsråd som Sponheim. Formuleringa «For å styrke inntektsgrunnlaget for landbruket, mener Regjeringen det er nødvendig at landbruksnoringen sikres muligheter til økt noringsmessig utnyttelse av utmarka» (St. meld. nr 19, 1999-2000, s. 18) var fundamentet til landbruksministerens gjentekne mantra om å «ta heile gardens ressursar $i$ bruk» (Sponheim, 2003). Grunneigarane i grendene skulle gjere seg til entreprenørar og starte tene pengar på utmarka. Dei skulle utnytte hugen dei nye utmarksbrukarane hadde for opplevingar. Jakt og fiske skulle ikkje lenger prisast etter kilo kjøt eller fisk, men etter verdien av opplevingane brukarane hadde når dei jakta og fiska. Der strategien for næringsutvikling knytt til vilt- og fiskeressursane på 1980- og 1990-talet hadde handla om utvikling av kommersielt innlandsfiske (Flø, 1998; Sandlund et al., 2004) og betre logistikk for mottak og distribusjon av viltkjøt frå jakta, handla det frå sist på 1990- og fyrst på 2000-talet om å lage «pakkar» for jaktande og fiskande gjestar som fyrst og fremst fiska for opplevinga og ikkje einast for matauk (Flø, 2015).

Gjennom den såkalla Fjellteksta i det reviderte nasjonalbudsjettet for 2003 (St. prp. nr. 65, 2002-2003) vart nasjonalparkar og verdsarvområde gjort til innsatsfaktorar for ny næringsutvikling i utmarka (Flø, 2013a). Utmarka og utmarkskulturen må kommodifiserast, sa ekspertane, og meinte at den skulle gjerast om til ei vare i seg sjølv og ikkje einast ei kjelde for å produsere mat og fiber (Flø, 2009, 2015). Alt dette endra utmarka, det endra lokalsamfunnet så vel som forholdet mellom menneske. Utmarka gjekk frå å vere beitemark, via ei utmark jamt meir nytta til det nære friluftslivet i kombinasjon med rekreasjonsprega hausting av bær, fisk og kjøt, til gradvis å bli eit middel for å lokke kundane til reiselivsoperatørane. Tanken var nok ikkje å redusere verdien av utmarka som 
beitemark, men snarare å auke den lokale verdiskapinga. Meir av verdiskapinga skulle skje lokalt, det skulle vere ein måte «å føre verdiskapinga attende til grendene», sa Sponheim og hans like (Flø, 2001). Slik skulle sysselsettinga og busetnaden i dei agrare grendene sikrast.

Og for all del, dette fungerte somme stadar, me såg at nokre fekk det til, men me såg òg at det ikkje var like lett alle stadar (Fedreheim, 2013; Flø, 2021). Men dette vart den nye økonomien. Me har gått frå ei utmark prega av å fyrst og fremst vere ein produksjonsressurs for gardbrukarane i bygdene, i tillegg til ein viktig del av ein haustingsbasert hushaldsøkonomi for bygdefolket, via ei utmark jamt meir nytta til det nære friluftslivet i kombinasjon med rekreativ hausting av bær, fisk og kjøt, til ei utmark som har vorte eit landskap for dyrking av identitetar gjennom opplevingar og sosialt samvær (Flø, 2010).

Kanskje vert dei tilfeldige og flyktige identitetane drivne fram av eit moderne statusjag, men kanskje er det like ofte det sterke bandet mellom folk og landskap, og då kanskje særleg utmarka, som berre har fått nye eller snarare fornya - utslag etter kvart som tida og tilhøva har endra seg, i byen så vel som på bygda. Uansett så vart dette den nye økonomien.

\section{Den nye økonomien}

Lat oss få utdjupe denne nye økonomien ved å presentere lesaren for den amerikanske filosofen og aktivisten Steven Best. Best er ny-marxist og sterkt inspirert av to eksentriske franske filosofar, Guy-Ernest Debord og Jean Baudrillard. Best (1989) skildrar framveksten av den nye økonomien gjennom nettopp å studere forbruket, og hevdar me går frå varesamfunnet, via skodespelsamfunnet til simuleringssamfunnet. Rett nok presenterer Best desse stadia, eller «samfunna», som at det eine avløyser det andre, og rett nok er han også nokså kategorisk i sin framstilling av dei. Likevel meiner me hans skildring er relevant, men då fyrst og fremst som at det eine stadiet bygger på det neste, og at me i dag er der at alle desse «samfunna» sameksisterer i den nye utmarka.

Det fyrste av desse «samfunna», altså varesamfunnet, kom med pengeøkonomien, seier Best. Og hans skildring av varesamfunnet er tungt forankra i Marx si forståing av kapitalismen. I varesamfunnet gjekk sauen 
frå å vere maten åt bonden til å verte vara som skaffa bonden maten. Det skjedde altså ein transformasjon frå mat til matvare. Og typisk her var at sjølve forbruket av vara skjedde utanfor bygda. Dette er mykje godt det samfunnet me vaks opp i. På 1970- og fyrst på 1980-talet var pengeøkonomien godt etablert i landbruket. Mjølka vart henta av tankbilen, og med jamne mellomrom kom dyretransporten, slik vart mjølk og livdyr henta for foredling i byen og derifrå distribuert til daglegvareforretningane der husstandane i både by og land henta sine daglege forråd.

I skodespelsamfunnet, som då er inspirert av Debord (1977), gjekk sauen igjennom enno ein transformasjon. No var vara opplevinga av å sjå bonden springe støvlane av seg under sankinga. Bonden er skodespelaren og sauen kulissene i det me opplever som eit autentisk teater om bygdekultur. Skodespelsamfunnet utgjer på mange måtar grunnlaget for satsinga på det nye rurale reiselivet som har vore så tydeleg vektlagt $\mathrm{i}$ både Stortingsmelding nummer 19 (1999- 2000) «Om norsk landbruksog matproduksjon» og i Skogmeldinga (St. meld. nr 17, 1998-1999). Same tenking finn me også att i fleire liknande offentlege dokument frå denne tida - regionale så vel som nasjonale - og ikkje minst i nyare meldingar, som til dømes «Opplev Norge - unikt og eventyrleg» (St. meld. nr 19, 2016-2017). Samstundes er det få eller ingen refleksjonar i desse meldingane om kva konsekvensar desse endringane vil kunne få for dei rurale samfunna eller utmarka.

I det siste stadiet - simuleringssamfunnet, som særleg er inspirert av Baudrillard (1983) - startar det heile å verte mesta abstrakt. For i simuleringssamfunnet deltek me sjølve i sauesankinga og simulerer at me er bønder. Og så tek me bilete av oss sjølve og postar det på Facebook, saman med ein fyndig tweet på 140 teikn. Alt for å projisere oss sjølve, alt for å syne oss fram, for å skape eit inntrykk av kven me sjølve meiner å vere, for å vise fram den versjonen av oss sjølve som me vil andre skal sjå oss som.

I sine skildringar av desse «samfunna» legg ikkje Best skjul på sin delvis moralske indignasjon for korleis samfunnet utviklar seg. Han kan lesast til å meine at moderniseringa har gjort samfunnet vårt meir overflatisk og fjerna oss jamt lenger vekk frå det «ekte» i tilværet. Også den norske antropologen Tord Larsen kan sjå ut til å dele Best sin moralske indignasjon. I sitt siste kapittel i boka Den globale samtalen (Larsen, 
2009) presenterer han si forståing av «Tingdannelsens ${ }^{4}$ former i vår tid» (s. 342-377) og hevdar at med tingdanninga - eller altså med kommodifiseringa - oppstår det også ei kategorisering av identitetar. Overført til utmarka kan ein seie at det vert kategoriar av utmarksbrukarar; me får hyttefolk, fjellvandrarar, klatrarar, padlarar og liknande, som alle definerer brukarane i grupper knytt til korleis dei brukar «tingen», altså utmarka. Med denne kategoriseringa vert det også lagt eit fundament for framveksten av ein særskild «identitet», ein identitet som i sin tur også utgjer grunnlaget for organisering innan særskilde og meir spesialiserte grupper av utmarksbrukarar, og i neste omgang også grunnlaget for kollektiv handling innan kvar av gruppene.

\section{Sterke interessegrupper}

Sjølv om organiserte interessegrupper for brukarar av utmarka ikkje er noko nytt, sjølv om me har hatt store og sterke organisasjonar for grunneigarinteressene så vel som for friluftslivsinteressene i lang tid, så vaks organisasjonsfloraen så vel som medlemstala for friluftslivsorganisasjonane raskt og mykje framover frå sist på 1960- og utover heile 1970-talet og langt inn på 1980-talet. Ikkje berre vart både Den Norske Turistforening (DNT) og Norges Jeger- og Fiskerforbund (NJFF) store og betydelege aktørar i utmarka så vel som i utmarkspolitikken, men jamt oftare såg me også at meir spesifikke utmarksbrukarar starta markere seg i debatten om kva utmarka er og kva den skal vere. Etter kvart fekk me eigne organisasjonar for padlarar så vel som for fjellklatrarar og for folk som likte å sykle i utmarka. Me fekk hytteeigarforeiningar og foreiningar for folk som sanka sopp og nyttevekstar, og ikkje minst fekk me ein jamt rikare tidsskriftsflora som også sikta seg inn mot dei smale segmenta av kategoriar av utmarksbrukarane.

Sist på 1980-talet - samstundes med den sterke veksten i medlemstala for dei store friluftsorganisasjonane våre - gjekk fleire saman i paraplyorganisasjonen Friluftslivets fellesorganisasjon (FRIFO), som seinare tok

4 Larsen brukar omgrepet tingdannelse på det Best omtalar som kommodifisering (commodification). 
namnet Norsk Friluftsliv. Slik vart friluftsinteressene samla under ein organisasjon, og på den måten vart friluftslivsinteressene også ei tydelegare politisk stemme i utforminga av utmarkspolitikken. Organisasjonen har jobba målmedvite for å fremje eit aktivt friluftsliv tufta på ein sterk og endåtil styrkt allemannsrett. ${ }^{5}$ Og nettopp allemannsretten kan fort kome i spel når interesser kjempar om posisjonar i utmarka. Auka rekreasjonsbruk og nye og meir «forstyrrande» aktivitetar går ikkje nødvendigvis like godt saman med ein tradisjonell og varare bruk. Derfor har me dei seinare åra sett at Norsk Friluftsliv så vel som medlemsorganisasjonane har stressa det som gjerne vert kalla allemanns-pliktene som følger retten. Som eit døme på det kan ein sjå til Norsk friluftsliv sin kampanje lansert i 2021, ${ }^{6}$ der skodespelar Bjørn Sundquist opererer som ein norsk Jack (Nicholson) Torrance for å fremje allemannspliktene i utmarka. Mindre påkosta appellar for skikk og bruk i utmarka finn ein jamt oftare også i den etter kvart så rike tidsskriftfloraen for ulike friluftslivsinteresser. Ryttarar, scooterkøyrarar, syklistar, jegerar, padlarar og andre vert heile tida minte på pliktene dei har som utmarksbrukarar gjennom redaksjonelle reportasjar og leiarar skrivne for nettopp å sikre allemannsretten. Slik kan kultur skapast, det kan skapast gjennom strukturar der aktørane sjølve deltek i danninga av seg sjølv og sine like. Men der det finst kultur, vil det alltid også vere ukultur, utfordringa vil alltid vere å stimulere kulturen til å vekse framfor ukulturen.

\section{Re-industrialisering, fornying av den gamle økonomien}

Fyrste nyttårsdag 2001 kunne dåverande statsminister Jens Stoltenberg fortelje at det no var slutt på norsk vasskraftutbygging i urøyvd natur. Dette førte til stopp i den planlagde utbygginga i Beiarn, Bjøllåga og Melfjord i Nordland, og mange vona truleg at dette også var inngangen til ein ny æra for industrialiseringa av utmarka. Samstundes, oppgjennom

\footnotetext{
5 https://norskfriluftsliv.no/om-oss/vart-oppdrag/

6 https://norskfriluftsliv.no/temaer/allemannsretten/allemannspliktene/
} 
heile 1980- og 1990-åra og godt inn på 2000-talet, hadde me vore vitne til ei jamn avvikling av mykje av gruvedrifta kringom i landet, og skogindustrien sleit med låge råvareprisar og dertil redusert hogst. Var no industrialiseringa av utmarka kome til endes?

Nei da. For det fyrste hadde nyleg ein ny industri vakse fram nett i denne perioden der den gamle såg ut til å bli svekt. For reise- og friluftslivet hadde gradvis utvikla seg til nettopp å bli ein industri, regionale destinasjonsselskap og jamt større reiselivsoperatørar hadde reidd grunnen for gode marknadstilpassa produkt som kunne «fly-in-fly-out» kundar i raskt tempo. I 2011 tok selskapet Fjord Tours imot «eksportprisen» av Innovasjon Norge for produktet «Norway in a nutshell», som tilbyr tettpakka høgdepunkt på kort tid. Sameleis hadde også jamt fleire kommunar i fjellet og langs fjordane lagt til rette for hyttebygging i von om at andreheimsbebuarane skulle halde liv i dei døyande grendene ein ordførarperiode eller to. For det andre såg dei som skjøna seg på dei store linene for dei internasjonale energi- og råvareprisane, at det neppe var enden på den gamle industrien dei såg då Stoltenberg tala, snarare såg dei berre ein sving på den same vegen. For i løpet av 2007 og ved inngangen til 2008 teikna grafane på råvarebørsane ei umiskjenneleg veksande kurve. På nytt vart gruvedrift interessant, sjølv i høgkostlandet Noreg, og saman med klimadebatten bles energikrisa vind i segla for kraftselskapa som ville produsere vindkraft langs kysten. Fleire stadar i landet kunne ein ane at me nærma oss ei ny-industrialisering av den norske utmarka, og dei tradisjonelle utmarksbrukarane - særleg reindriftsnæringa og andre beitebrukarar - såg med uro på framveksten av den nye utmarka.

\section{Bidraga i boka}

Denne boka har kome i stand som følgje av eit nettverksprosjekt finansiert av Norges forskingsråd, der eit knippe forskarar som er engasjert i temaet utmark, har møttest for å drøfte statusen og utfordringane me står overfor i høve bruk og forvalting av utmarka. Som ein freistnad på å nå eit større publikum enn einast oss sjølve bestemte me oss for å sette saman ei bok som syner nokre av dei temaa som var opp til drøfting i gruppa. Det er ikkje meint å vere uttømande eller på nokon måte å skulle dekke 
alle dei utfordringane me står overfor, men mest berre å gi eit innblikk i nokre av dei temaa som me har vore innom i nettverket.

Kapitla er skrivne av nokre av dei fremste samfunnsforskarane våre innanfor feltet utmark, og kvar for seg gir kapitla innsikter på spesielle tematiske område innanfor forskinga.

I kapittel 2 «Reindriftas sårbarhet og Norges ansvar» drøftar Jan Åge Riseth, Svein Morten Eilertsen og Bernt Johansen ei av dei største utfordringane den samiske reindrifta står overfor om dagen, nemleg tap av areal. Korkje politikarar eller folk flest ser ut til å vere klar over kor sårbar reindrifta er for utbygging av infrastruktur og menneskeleg aktivitet, hevdar dei. Derfor har me heller ikkje vektlagt å bygge institusjonar som i stor nok grad tek vare på arealet reindriftsnæringa treng for å oppretthalde drifta. Forfattarane dokumenterer påstandane sine gjennom ein analyse av arealbruksutfordringane i to reinbeitedistrikt og syner at dei akkumulerte effektane av tidlegare arealtap er tap av fleksibilitet. Nett det tapet gjer også tilpassing til nye utfordringar endå vanskelegare for reindrifta. Kapittelet kjem også med forslag til korleis forvaltinga og me som samfunn kan møte desse utfordringane.

I kapittel 3 «Mot ei framtid for utmarksbeite - om beiting, sjølvkjensle og forståing mellom folk» tek Bjørn Egil Flø oss med på vitjing hjå sauebønder kringom i landet. Kapittelet drøftar framveksten av «den nye utmarka» og korleis den har påverka utmarksbeitet. Basert på samtalar med beitebrukarar i ulike delar av landet drøftar Flø framtida for utmarksbeite opp mot dei store, så vel som dei små, politiske og sosiale spørsmåla både beitebrukarane og me som samfunn står overfor. For dei strir med mange spørsmål om dagen, beitebrukarane. Er det ikkje lenger økologisk berekraftig å nytte utmarksressursane til matproduksjon? Skal ikkje utmarka vere ein ressurs for produksjon av mat og fiber i framtida? Dette og meir er spørsmål beitebrukarane spør seg i dag. Dei kjenner seg degradert og uthengt i det offentlege ordskiftet, og kjensla riv i sjølvbiletet deira og gjer kvardagen mindre kjekk, og det vert vanskelegare å finne motivasjon for kvar dag som går. Essayet dreg opp ei rekke viktige spørsmål som me som samfunn treng å ta inn over oss i debatten om kva utmarka er og kva den skal vere. 
I kapittel 4 «Kampen om utmarka: Hytter, beitemark eller urørt natur?» ser Jørund Aasetre på interessemotsetningane mellom tradisjonelle utmarksnæringar, naturvern og turisme og hytteutbygging. Utgangspunktet for kapittelet er Oppdal, og Aasetre kviler på fleire kjelder når han identifiserer fire ulike diskursar knytt til utmarksforvaltinga på Oppdal. Avslutningsvis drøftar forfattaren særleg den siste av dei fire diskursane - vinn-vinn-diskursen - og meiner det er eit ope spørsmål om den diskursen representerer ei tilstrekkeleg omlegging av arealbruken, eller om det einast representerer ei «grønvasking» av hyttenæringa.

I kapittel 5 «Fritidsbygg i fjellområdet - en egen boligstruktur?» er det utviklinga av dei mange fritidsbustadfelta i utmarka som er temaet. Tor Arnesen og Stine Kvamme tek utgangspunkt i 104 kommunar i Sør-Noreg der det på 200o-talet har vorte bygd tre fritidsbustader for kvar einebustad. Forfattarane spør om fritidsbustadane har vakse fram etter ein overordna plan, eller om det er eit samla resultat av ei rekkje individuelle handlingar. Arnesen og Kvamme samanliknar den raude (ordinære bustader) og den grøne (fritidsbustader), og finn at medan den raude bustadstrukturen er ein del av eit offentlegrettsleg rom, så er den grøne bustadstrukturen gjennomgåande privatrettsleg regulert. Det er stor ulikskap mellom korleis desse bustadstrukturane er handsama i plansystemet. Forfattarane konkluderer med at det er eit stykke fram til at den grøne bustadstrukturen blir oppfatta som nettopp ein bustadstruktur, og sender med dette ut ei etterlysing etter ein klarare fritidsbustadpolitikk.

\section{I kapittel 6 «Rettslege rammer for klimavenleg energiproduksjon i} utmarka: Utfordrar klimaomsynet legitimiteten til konsesjonsregelverket?» tek Katrine Broch Hauge utgangspunkt i klimautfordringane som stadig aktualiserer utbygging av fornybar energi i utmarka. Samstundes som ei slik utbygging skal bidra til ein meir klimavenleg energiproduksjon, kan den også føre til tap av naturmangfald, som er ei av dei andre store utfordringane verda står overfor. Broch Hauge brukar det juridiske blikket når ho ser på kva som gir ein rettsregel legitimitet når slike kryssande omsyn skal vegast opp mot kvarandre. Nøkkelen ligg 
ifølgje Broch Hauge i å synleggjere betre dei avvegingane som må gjerast innanfor dei rettslege rammene. Då må ein utvikle styringsverktøya slik at arbeidsdelinga mellom planlegging på regionalt og lokalt nivå fungerer betre, og at ein dermed styrkjer det lokaldemokratiske fundamentet.

\section{I kapittel 7 «Menneske og dyr i grenseland - om rettar, rettferd og rett} ferd i utmarka» er det grenser og grensedragningar som blir diskutert. Frode Flemsæter og Katrina M. Brown presenterer funn frå eit forskingsprosjekt om endringar og interessekonfliktar i den midt-norske utmarka, mellom anna den tradisjonelle sør-samiske reindrifta sitt møte med stadig nye utmarksbrukarar. Forfattarane tek for seg utfordringane det fører med seg når ulike aktørar har eit grunnleggjande ulikt syn på kva ei grense i utmarka er. Grensene som den sør-samiske reindrifta held seg til, er fleksible og flytande, og skiftar i takt med dyra si åtferd og naturens sesongvariasjonar. Planforvaltinga tenkjer annleis, og har dei statiske grensene på kartet som eit viktig verktøy i utmarksforvaltinga. Implikasjonane av dette er ifølgje Flemsæter og Brown at ulike grupper sitt høve til å respondere på endra verdsetting av utmarksressursar og tilhøyrande forvaltingspraksisar er ulikt. Dermed meiner dei at grenser og grensedragningar i utmarka ikkje berre handlar om rettar, men òg om rettferd.

\section{I kapittel 8 «Rovviltforvaltning og reindriftsnæringen: Hvordan kan} en todelt målsetting praktiseres i samsvar med internasjonale konvensjoner?» tek Svein Morten Eilertsen og Jan Åge Riseth tak i den tydelege auka i tapet av reinskalvar som reindriftsnæringa har opplevd på 200o-talet. Eilertsen og Riseth peikar på at reindriftsnæringa har utfordringar med å dokumentere kven som er skadegjerar, medan ein slik dokumentasjon er avgjerande for ei eventuell felling av rovdyr. Analysane koplar dei til samfunnsendringar elles, og peikar på at beitenæringane sin posisjon i utmarka er stadig meir utsett. I likskap med kapittel 6 meiner forfattarane at mykje av løysinga ligg i å sjå på ansvarsfordelinga mellom forvaltingsnivåa. Eilertsen og Riseth argumenterer for at rovviltforvaltinga bør delegerast til regionalt nivå, og at då beitebrukarar sin lokale og tradisjonelle kunnskap i større grad enn no bør leggast til grunn for avgjersler. 
I kapittel 9 «Stien i endring? Om det godes paradoks» skriv Odd Inge Vistad om stien. Vistad har eit langt liv som friluftslivsforskar, men han har også eit langt liv som brukar av stiar. Begge desse erfaringane brukar Vistad når han tek lesaren med på ei forteljing om kva stien er, korleis stien sitt særpreg har utvikla seg over tid, korleis stien etter kvart har fått ei offentleg forvalting og kommersiell betyding, og kva funksjon stien har og har hatt til ulike tider. På vegen kastar forfattaren òg eit blikk mot den svenske stien. Vistad viser til det aukande omfanget av opparbeidde, merka og tilrettelagte stiar som infrastruktur i det norske friluftslivet. Han meiner det er grunn til å reflektere over om «det beste er det godes fiende» òg i friluftslivet - altså om me i søking etter å lage den «beste» stien gjer det «gode» friluftslivet mindre godt.

I kapittel 10 "Har utmarka blitt historie?» skriv Knut Fageraas om alle kulturspora som me finn i utmarka. Kapittelet handlar altså om utmarkas kulturarv. Folk har bruka utmarka og utmarksressursane på mange måtar over lang tid. Og i utmarkslandskapet finn me spor etter denne bruken slik at me kan lese kulturhistoria gjennom landskapet. Fageraas peikar på at det er ei stor merksemd rundt utmarkas kulturarv, men at for å få ei forståing av denne kulturhistoriske interessa for kulturminne i utmarka, må ein sjå dette i lys av miljøforvaltinga sitt fokus på verdiskaping og bærekraft for å skape utvikling. Med endra og utvida utmarksbruk kan kulturminna i utmarka lesast som meir enn ei historiebok - dei har både kunnskaps-, opplevings- og bruksverdi, som mange forskjellige slags aktørar engasjerer seg i. Kulturmiljøa i utmarka er mangfaldige og rike, knytt til både fortid og framtid, men dette kan ifølgje forfattaren òg auke potensialet for at kulturarvens dissonans kan provosere fram meir konflikt mellom aktørar med ulik verdsetting av utmarksressursane.

I kapittel 11 «Utmarksetikk i endring?» viser May Thorseth korleis endringar i bruken av utmarka utfordrar etablerte etiske standardar for bruken. Thorseth peikar på at etiske standardar tidlegare har vore nedfelt gjennom kulturen, medan ny og utvida bruk av utmarka har skapt 
eit større behov for å formelt regulere dei etiske standardane. Kapittelet har som mål å diskutere og utdjupe forståinga av nokre etiske dilemma som knapt kan løysast gjennom juridiske reguleringar åleine. Gjennom ei drøfting av ulike etiske prinsipp stiller Thorseth viktige spørsmål om korleis me skal navigere i utmarksforvaltinga i spennet mellom individa sine interesser og behov og fellesskapets beste.

\section{Litteratur}

Almås, R. (1977). Norsk jordbruk - det nye hamskiftet. Gyldendal.

Baudrillard, J. (1983). Simulations. Semiotext(e).

Beck, U. \& Beck-Gernsheim, E. (2002). Individualization. Sage Publications.

Beck, U., Giddens, A. \& Lash, S. (1994). Reflexive modernization: Politics, tradition and aesthetics in the modern social order. Polity Press in associaton with Blackwell Publishers.

Benjaminsen, T. A. \& Svarstad, H. (2008). Understanding traditionalist opposition to modernization: Narrative production in a Norwegian mountain conflict. Geografiska Annaler: Series B, Human Geography, 9o(1), 49-62.

Best, S. (1989). The commodification of reality and the reality of commodification: Jean Baudrillard and post-modernism. Current Perspectives in Social Theory, 19, 23-51.

Daugstad, K., Rønningen, K. \& Skar, B. (2006). Agriculture as an upholder of cultural heritage? Conceptualizations and value judgements - a Norwegian perspective in international context. Journal of Rural Studies, 22(1), 67-81.

Debord, G. (1977). Society of the spectacle. Black \& Red.

Eriksen, T. H. (2004). Røtter og føtter - identitet i en omskiftelig tid. Aschehoug.

Fedreheim, G. E. (2013). Value creation on Norway's green gold: An analysis of policy formulation and implementation in the field of nature conservation. [Doktorgradsavhandling]. Universitetet i Nordland.

Flø, B. E. (1998). Institusjonelle ordningar rette mot forvalting av rurale ressursar Sikfisket i Femund (R 4/98). Senter for bygdeforskning.

Flø, B. E. (2001). Organic farming in margenalized areas: A study from Norway.

I R. A. Caufield \& M. Kojima (Red.), Northern communities and the global economy. Department of Alaska Native \& Rural Development.

Flø, B. E. (2009). Vondtet i norsk bygdeutvikling. Syn og Segn, (3), 76-80.

Flø, B. E. (2010). Bygda - forståing og implikasjonar. PLAN, (5), 20-25.

Flø, B. E. (2012). Arealpress i utmark. PLAN, (3-4/2012), 76-79.

Flø, B. E. (2013a). Kulturarv og verdiskaping i eit kyst-innlandsperspektiv (Rapport 2/2013). Norsk senter for bygdeforskning. 
Flø, B. E. (2013b). Me og dei andre. Om lindukar, Framstegspartiet og bygda som sosial konstruksjon. Sosiologisk tidsskrift, 21(2), 152-168.

Flø, B. E. (2015). Bygda som vare - om bygda, elgen og folkeskikken

[Doktorgradsavhandling]. Noregs teknisk- naturvitskaplege universitet.

Flø, B. E. (2018). Av svik kom mistru sigande. Samtiden, (1), 54-61.

Flø, B. E. (2021). Bygda som vare. Arr Idéhistorisk tidsskrift, 33(1), 16-31.

Fulsås, N. (1996). Kvifor fekk ikkje industrikapitalismen fotfeste i Nord-Norge?

I E. O. Eriksen (Red.), Det nye Nord-Norge (s. 39-70). Fagbokforlaget.

Goodhart, D. (2017). The road to somewhere: The populist revolt and the future of politics. Hurst.

Krokann, I. (1982). Det store hamskiftet i bondesamfunnet (3. utg.). Det norske samlaget. (Opprinneleg gjeven ut 1942)

Larsen, T. (2009). Den globale samtalen. Om dialogens muligheter. Scandinavian Academic Press.

Murdoch, J. \& Pratt, A. C. (1993). Rural studies: Modernism, postmodernism and the 'post-rural. Journal of Rural Studies, 9(4), 411-427.

Nerbøvik, J. (1999). 1860-1914: Eit bondesamfunn i oppbrot (Bd. 5). Det Norske Samlaget.

Sandlund, O. T., Berge, E., Flø, B. E., Saksgård, R. \& Ugedal, O. (2004). Whitefish fisheries in mountainous southeastern Norway - abundant resources, but scarce fishermen. Mountain Research and Development, 24(1), 67-74.

Sponheim, L. (2003). Tale for Den nasjonale kongress for økologisk landbruk. 5. 11. Hamar.

St. meld. nr 17. (1998-1999). Verdiskaping og miljø - muligheter i skogsektoren. Landbruksdepartementet.

St. meld. nr 19. (1999-2000). Om norsk landbruk og matproduksjon. Landbruksdepartementet.

St. meld. nr 19. (2016-2017). Opplev Norge - unik og eventyrlig. Nærings- og fiskeridepartementet.

St. prp. nr. 65. (2002-2003). Tilleggsbevilgninger og omprioriteringer i statsbudsjettet medregnet folketrygden 2003. Finansdepartementet.

Vinge, H. \& Flø, B. E. (2012). På gjengrodde stier. I M. Rønningen \& T. Slåtten (Red.), Innovasjon og noringsutviklng i en reiselivskontekst (s. 279-296). Fagbokforlaget.

Vinge, H. \& Flø, B. E. (2015). Landscapes lost? Tourist understandings of changing Norwegian rural landscapes. Scandinavian Journal of Hospitality and Tourism, 15(1-2), 29-47.

Vinje, A. O. (1861). Ferdaminni fraa sumaren 1860. Bergh \& Ellessen. 



\title{
KAPITTEL 2
}

\section{Reindriftas sårbarhet og Norges ansvar}

\author{
Jan Åge Riseth
}

NORCE Norwegian Research Centre

Svein Morten Eilertsen

Norsk institutt for bioøkonomi (NIBIO)

\section{Bernt Johansen}

\section{NORCE Norwegian Research Centre}

\begin{abstract}
In Norway, the reindeer exists as both a wild and semi-domesticated species. The latter forms the basis of a livelihood and industry that is the clearest characteristic of Sámi culture, and it is protected by international law and the Norwegian Constitution. Nevertheless, reindeer herding is threatened by loss of land used for infrastructure and recreation facilities development, as well as human activities in the outfields (utmark). Reindeer are physically vulnerable, and society's institutions do not provide sufficient protection of land for grazing and herding of reindeer. Politicians and the general public are largely unaware of this. The chapter documents this by analyzing land-use challenges in two reindeer-herding districts. Besides loss of pastureland, the accumulated effect of former losses is a loss of flexibility, which makes adaptation to new challenges increasingly difficult. The authors suggest several practical measures (e.g. plans, maps, etc.), but also point to the need for general education in Sámi culture and affairs, for politicians as well as the public. This should be a part of necessary reconciliation processes in the context of historical assimilation policies. Furthermore, the Norwegian government should strengthen its efforts to realize the intentions of plan and building laws by strengthening local and regional government obligations.
\end{abstract}

Keywords: encroachments, natural foundation for Sámi culture, political perspectives, reindeer, reindeer herding, vulnerability 


\section{Introduksjon}

Reinsdyret i Norge og Fennoskandia, nærmere bestemt underarten eurasiatisk tundrarein ${ }^{1}$ (Rangifer tarandus tarandus), er en av de siste overleverne fra den store boreale megafaunaen fra siste istid (Kurtén, 1969). Dette tyder på at nettopp reinen er spesielt tilpasningsdyktig overfor endringer i livsmiljøet. Som figur 1 viser, er den fortsatt utbredt over det meste av Fennoskandia. ${ }^{2}$ Selv om underarten klarer seg relativt godt, kom villreinen inn på rødlista for truede arter i 2016, med status som sårbar (Gunn, 2016). Tamreinen er også utsatt, og reinen har derfor myndighetenes oppmerksomhet både som natur- og kulturelement. Slik har den en unik dobbeltposisjon i norsk utmarksforvaltning. Som villrein i det sentrale Sør-Norge er den en europeisk ansvarsart. Det er etablert nasjonale villreinområder og europeiske villreinregioner forvaltet gjennom regionale villreinplaner (Kjørstad et al., 2017). Som tamrein i Midt- og Nord-Norge utgjør reindrifta det mest særegne grunnlaget for samisk kultur. Naturgrunnlaget for samisk kultur har beskyttelse i folkeretten og Grunnloven og søkes ivaretatt gjennom egne bestemmelser i relevante lover som reindriftsloven, plan- og bygningsloven og naturmangfoldloven (Ravna, 2019).

I dag er den langsiktige bærekraften til både villrein og tamrein truet av innskrenkning og fragmentering av leve- og driftsområder som følge av tap av areal til ulike utbyggingsformål. I tillegg unnviker dyrene beiter og bruksareal på grunn av forstyrrelser fra fysiske installasjoner og mange former for menneskelige aktiviteter. Omfattende infrastrukturutbygging, nye typer energianlegg - både vindturbinparker og kraftoverføringslinjer, ekspansjon i hyttebygging, rekreasjonsanlegg og -aktiviteter er noen eksempler på at tidligere relativt uforstyrrede fjell- og utmarksområder gjennom flere tiår har blitt gjenstand for et stadig sterkere arealpress (Riseth \& Johansen, 2019). Utover dette er reinen truet av ulike klimaendringseffekter (Riseth \& Tømmervik, 2017) og også av en

\footnotetext{
1 Også tallrik og utbredt i hele det nordlige Sibir.

2 I tillegg til tundrareinen finnes to andre underarter i Norden: Svalbardrein (Rangifer tarandus platyrhynchus) og finsk skogsrein (Rangifer tarandus fennicus) i sørøstlige Finland.
} 
rovdyrforvaltning som i stor grad overfører kostnadene ved rovdyrholdet til beitenæringene (Danell, 2010; Risvoll et al., under utgivelse; se også kap. 8). Villreinen har betydelige utfordringer (Nilsen \& Strand, 2017), men vi skal her konsentrere oss om tamreindriftas situasjon.

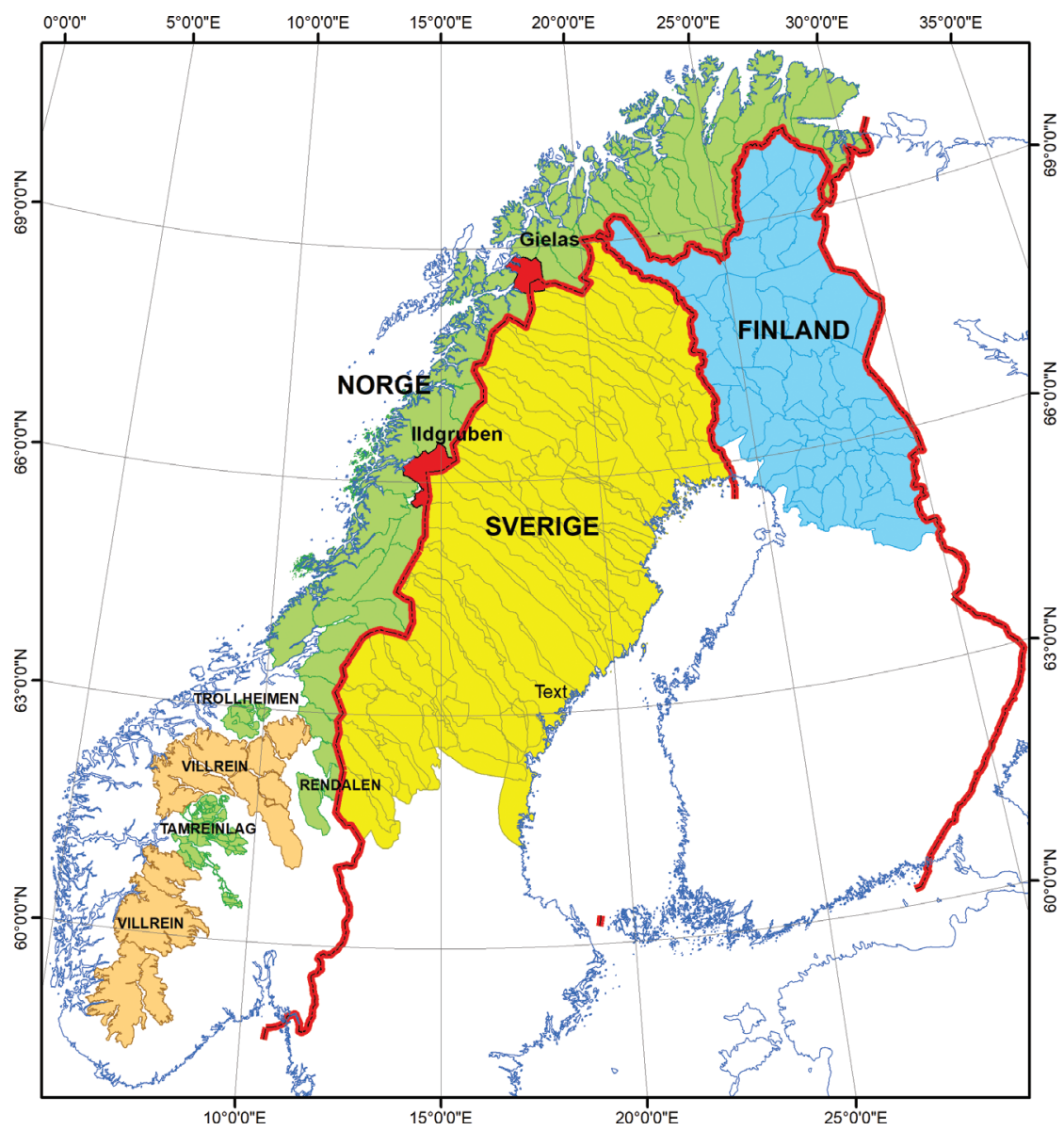

Figur 1. Reindrift og villrein i Fennoskandia. (Kilder: landbruksdirektoratet.no, miljodirektoratet. no, sametinget.se, paliskunnnat.fi).

De siste tiårene har det blitt iverksatt reformer som forutsetningsvis er forventet å lette presset på arealene og bidra til økt stabilitet. Likevel står reindrifta i en kompleks pressituasjon både økologisk og samfunnsmessig. I dette kapittelet tar vi sikte på å undersøke reindriftas inngrepssituasjon nærmere for å forstå hvilke prosesser i natur og samfunn som 
er avgjørende for at reindrifta skal kunne vedlikeholde sin arealbruk og kunne drives videre på en kulturelt akseptabel og økonomisk regningssvarende måte. På bakgrunn av litt teori skal vi ta utgangspunkt i utfordringene for to reinbeitedistrikter (jf. figur 1) og den samlede virkningen av ulike typer inngrep.

\section{Resiliens og sårbarhet}

Økosystemers evne til å gjenvinne ny balanse etter en forstyrrelse kalles resiliens (Holling, 1973) og kan forstås som tilpasningsevne. Resiliens er beslektet med sårbarhet. Svekket resiliens innebærer økt sårbarhet (Watson et al., 1996). Innsikter fra økologien koplet med økonomi og sosiologi gir grunnlag for teorier om resiliens og sårbarhet i sosial$ø$ kologiske systemer (Gunderson \& Holling, 2002). Dette gir utgangspunkt for å vurdere alle typer negative påvirkninger og deres effekter i sammenheng. Vi skal ta utgangspunkt i sårbarhet og skille mellom fysisk og institusjonell sårbarhet.

\section{Fysisk sårbarhet}

For å forstå den fysiske sårbarheten trenger vi innsikt i reinens bruk av landskapet og reinens og reindriftas årssyklus (Svonni, 1983). Reinen er avhengig av ulike plantesamfunn til forskjellige tider av året, og den er derfor i stadig bevegelse på ulike skalanivå; daglig i helt lokalt nærings$s ø k$, innen større områder som dekker et årstidsbeite eller funksjonsområder som brunst- eller kalvingsland, og på trekk eller flytting mellom sesongbeiteområder. Bevegelsene skjer også opp og ned i terrenget, raskt som følge av værforhold og insektplage eller sesongmessig som følge av tilgjengelig beite (Skarin \& Åhman, 2014).

Forskninga omkring rein, reindrift, arealinngrep og forstyrrelseseffekter har utviklet seg mye de siste tiårene. Dagens forskning legger til grunn at inngreps- og forstyrrelseseffekter må vurderes på flere skalanivå, fra det helt lokale til hele reinbeitedistrikter eller driftssystemer. En oppsummeringsartikkel av de siste årtienes forskning på feltet (Skarin \& Åhman, 2014) påpeker: 
- Rein vil ha en tendens til å unnvike permanente inngrep eller kontinuerlig forstyrrelser med alt fra få hundre meter opp til $15 \mathrm{~km}$.

- $\quad$ Det er en tendens til lengre unnvikelsesavstander når menneskelig aktivitet inngår i forstyrrelsen, også for tamrein.

- Unnvikelsesatferd fra gode beiteområder vil åpenbart medføre økt tetthet av rein på alternative områder. Dette vil, avhengig av kvaliteten på og utnyttelsen av disse, kunne påvirke både ernæring, overlevelse og reproduksjon for berørt rein.

- Generelt er rein mest sensitive for forstyrrelser på seinvinteren, mens simler er mest sensitive i kalvingsperioden. Voksne simler er også generelt de mest sensitive dyra i flokken. ${ }^{3}$ Dette samtidig som de også er den dominerende dyrekategorien hos tamrein.

- Det er vanskelig å påvise at tamrein over tid venner seg til inngrep og forstyrrelser, mens begrensing av forstyrrelsen har påviselig effekter (Skarin \& Åhman, 2014).

Det er vanlig å dele inngrepseffekter i (1) direkte lokale effekter, (2) indirekte regionale effekter og (3) kumulative effekter (Tsunokawa \& Hoban, 1997). De direkte effektene omfatter bl.a. fysisk tap av beite og forstyrrelse av enkeltdyr, mens indirekte regionale effekter angår hele flokken i det aktuelle området, bl.a. unnvikelses- og barriereeffekter (Vistnes et al., 2004). Kumulative effekter er de samlede langvarige effektene av en utbygging. Nærmere bestemt defineres det som «sumeffektene av tidligere, nåværende og planlagte inngrep og forstyrrelser» (Nilsson et al., 2015). Samme forståelse er også lagt til grunn i konsekvensutredningsforskriften (Forskrift om konsekvensutredninger, 2017) med hjemmel i plan- og bygningsloven.

Infrastrukturtiltak som hver for seg kan ha begrenset effekt, vil til sammen kunne medføre store akkumulerte effekter (Larsen et al., 2016). Det betyr at under uheldige omstendigheter kan et tilsynelatende begrenset inngrep få uforholdsmessig store effekter - som dråpen som får begeret til å flyte over. Effekten av et nytt inngrep eller en ny forstyrrelse vil 
derfor i stor grad være betinget av hvordan inngrepseffektene samvirker med effekter av tidligere inngrep/forstyrrelser. Dette betyr at man ikke kan vurdere hvert inngrep isolert. De må sees i en sammenheng (Norges Høyesterett, 2021). Over tid har det skjedd en omfattende nedbygging og fragmentering av naturlige beitelandskaper. Dette har ikke bare redusert tilgjengelig beiteareal. Det har også redusert potensialet for fleksibel bruk av landskapet (Löf, 2014).

Fleksibilitet er grunnleggende nødvendig for reinens tilpasning til variasjon i naturforholdene mellom år; temperatur og snøforhold, tidlig og sein vår osv. Når inngrep og forstyrrelser danner barrierer som hindrer optimal beitebruk, er det en grunnleggende reindriftssamisk strategi, i den grad det er mulig, å omorganisere beitebruken (Rørholt, 2009, s. 28), f.eks. å bruke høstvinterbeitet (dvs. seinhøstes) på vårvinteren (dvs. seinvinteren). Muligheten til omorganisering gir resiliens, men omorganisering kan samtidig øke sårbarheten, da den nye beitebruken ofte er mindre gunstig enn den opprinnelige. Selv om alle effekter ikke er like synlige, innebærer all omorganisering merkostnader i form av ekstra arbeid, redusert beitero/opptak, direkte utlegg til transport eller tilleggsfôring m.m. Dersom de samlede inngrepseffektene blir for omfattende, kan resiliensen bli liten og sårbarheten stor. I ytterste konsekvens kan det bli ulønnsomt eller meningsløst å fortsette som reineier (Fjellheim, 2020) - dvs. det finnes økonomiske og kulturelle tålegrenser for inngrep. Norge kan da komme i konflikt med folkerettens kulturvernbestemmelser i FNs konvensjon om sivile og politiske rettigheter (SP) art. 27 (Internasjonal konvensjon om sivile og politiske rettigheter, 1966; Norges Høyesterett, 2021; Olje- og energidepartementet [OED], 2016).

\section{Institusjonell sårbarhet}

Institusjonell sårbarhet (Selznik, 1951) kan forstås som begrensningene i kapasiteten samfunnets institusjoner har til å gjennomføre tiltak som beskytter, i vårt tilfelle reindrifta, mot inngrep og forstyrrelser. For å forstå den institusjonelle sårbarheten omkring samisk reindrift må man ha kunnskap om det særegne ved reindrift og samiske forhold 
både i historie og samtid. Samene, og enda mer reindriftssamene, ${ }^{4}$ særlig utenfor indre Finnmark, er en liten minoritet. De er samtidig tradisjonelle og i stor grad historisk dominerende brukere av utmarka i deler av Sør-Norge og nesten hele Midt- og Nord-Norge. Som en del av den norske nasjonsbygginga ble samene fra midten av 18oo-tallet marginalisert, og reindrifta ble stigmatisert som en utdøende næring. En politikk hvor reindrifta kunne tolereres, men måtte vike for andre interesser, spesielt ekspanderende norsk jordbruk, var rådende fram til 1960-tallet (Pedersen, 2015). En hardhendt fornorskningspolitikk omfattet både undergraving av rettigheter og livsgrunnlag (Fjellheim, 2012; Ravna, 2019) og regelrett fordriving av reindriftssamer, det siste særlig i Troms (Labba, 2020).

Denne politikken har langsomt snudd fra og med 1960-tallet. Den samiske etnopolitiske bevegelsen, i allianse med den internasjonale urfolksbevegelsen og miljøbevegelsen, la særlig fra 1970- og 80-tallet og gjennom Alta-aksjonen grunnlag for omfattende endringer i både internasjonal og nasjonal politikk. I Norge fikk Grunnloven en egen sameparagraf (1988), Sametinget ble etablert (1989), og Norge har også ratifisert flere viktige internasjonale konvensjoner. ${ }^{5}$ At samene er anerkjent som urfolk innebærer at myndighetene plikter å ta særlige hensyn for å identifisere, inkludere og legge vekt på samiske interesser i samfunnsplanleggingen.

Hovedbestemmelsen i plan- og bygningsloven slår fast at loven skal «sikre naturgrunnlaget for samisk kultur, næringsgrunnlag og samfunnsliv» (2008, \$ 3-1c). ${ }^{6}$ Norge står i dag offisielt for en progressiv urfolkspolitikk, men ettervirkninger og konflikter etter den gamle politikken er fortsatt høyst levende (Sannhets- og forsoningskommisjonen, u.å.).

4 Samisk reindrift i Norge har registrert 3329 personer i 535 siidaandeler (formelle familieenheter) (Landbruksdirektoratet, 2020).

5 Bl.a. den europeiske menneskerettskonvensjonen (1953), FNs konvensjon om sivile og politiske rettigheter (1972) og ILO-konvensjonen om urfolksrettigheter (1990). Norge har også styrket samenes stilling i norsk rett gjennom menneskerettsloven (1999).

6 Virkeområdet tilsvarer omtrent det samiske reindriftsområdet (se figur 1). 
Samtidig har også omfanget av naturinngrep og fragmentering av sammenhengende naturområder økt til alarmerende nivåer ${ }^{7}$ (Riseth \& Johansen, 2019). Det er grunn til å spørre om hvor langt urfolkspolitikken virker i praksis, og hva det i så fall er som skaper begrensningene. Er det institusjonell treghet (stiavhengighet), reelle interessemotsetninger, gamle fordommer eller mangel på kunnskap om samiske forhold? Bildet er sammensatt, men før vi diskuterer det nærmere, skal vi gi et bilde av inngrepssituasjonen i to utvalgte reinbeitedistrikter: Ildgruben $i$ Nordland og Gielas i Troms.

\section{Reindrifta i Norge}

Figur 1 viser utbredelsen av både villrein og tamreindrift i Norge sett sammen med nabolandene. Nesten hele Nord-Norge og Trøndelag fra innland til kyst sørover til og med Fosen, og i innlandet sør til Femunden dekkes av reinbeitedistrikter. Dette utgjør det samiske reindriftsområdet i Norge; omtrent 40 prosent av Fastlands-Norges areal. Her har reindriftssamene driftsrettigheter uavhengig av grunneierforhold (Reindriftsloven, 2007). Sør og vest for reindriftsområdet har vi såkalte konsesjonsområder, dvs. drifta er avhengig av grunneiertillatelse og konsesjon fra Staten. Med to unntak er dette tamreinlag (andelslag) med ikke-samisk reindrift i fjellbygder, de fleste i Jotunheimen. Det ene unntaket er Trollheimen, som bortsett fra rettsforholdene drives som et vanlig reinbeitedistrikt (Danielsen \& Riseth, 2010), mens det andre er Rendal renselskap (www.rendal-renselskap.no) som er en slags privat villreinforvaltning. Det er villreinområder både nord og sør for tamreinlagene og relativt nært den samiske reindrifta i Sør-Trøndelag/ Hedmark. ${ }^{8}$ En del villrein er tidligere forvillet tamrein (Kjørstad et al., 2017; Røed, 2014).

7 Jf. også Det internasjonale Naturpanelet, IPBES (Miljødirektoratet, u.å.).

8 DNA-analyser viser at det er genetisk forskjell på reinen i (1) Rondane/Dovre-regionen, (2) Langfjellaregionen og (3) bestander av primært tamrein, samt villrein med tamreinopprinnelse (Røed, 2014). Artsdatabanken.no angir at villreinen i 16 av 23 forvaltningsområder er basert på tamrein. 
Reindrifta i Norge omfattet pr. 31. mars 2020 omtrent 214000 rein i vårflokk (før kalving). Av disse beiter nesten 150 ooo i Finnmark og 12 ooo-14 ooo i hvert av reinbeiteområdene Troms, Nord-Trøndelag, Sør-Trøndelag/Hedmark og tamreinlagene (i sentrale Sør-Norge). Villreinen i Sør-Norge utgjør omtrent 25 ooo rein. Reindrifta i Finnmark er dominerende med om lag 70 prosent av tamreinen. Dette skyldes store og naturlig gode vinterbeiter ${ }^{9}$ på Finnmarksvidda. Vi har gjennomført en casestudie og valgt ut to reinbeitedistrikter som er ansett som veldrevne distrikter, men som også er sterkt berørt av inngrepseffekter. Distriktene ligger i Nordland og Troms og dermed utenfor det samiske majoritetsområdet (Indre Finnmark). Utfordringene de har forutsettes rimelig typiske for store deler av reindriftsområdet ellers.

Tabell 1. De to reinbeitedistriktene (Landbruksdirektoratet, 2020)

\begin{tabular}{lccccccc}
\hline Distrikt & Siidaandeler & Personer & $\begin{array}{c}\text { \# Estimerte } \\
\text { tap }\end{array}$ & $\begin{array}{c}\text { Øvre } \\
\text { reintall }\end{array}$ & $\begin{array}{c}\text { Reintall } \\
\mathbf{3 1 . 0 3 . 2 0 2 0}\end{array}$ & \# slakt & Slakt kg \\
\hline Ildgruben & 2 & 10 & 344 & 900 & 883 & 168 & 6688 \\
\hline Gielas & 4 & 34 & 705 & 2400 & 1641 & 516 & 12228 \\
\hline
\end{tabular}

\section{Ildgruben reinbeitedistrikt}

Distriktet er det nordligste reinbeitedistriktet i sørsamisk område. Det ligger i indre Rana og omfatter deler av kommunene Rana, Hemnes og Hattfjelldal, se figur 2. Distriktet har to 2 siidaandeler, og øvre reintall er 900 rein i vårflokk. Distriktet står for en betydelig verdiskaping, både direkte gjennom omsetning av reinkjøtt, men også gjennom tilleggsnæringer i tilknytning til reindrifta.

\section{Beitebruk og inngrep}

Vi skal følge beitebruken gjennom årets gang og kommentere inngrep underveis. Distriktet brukes som helårsdistrikt, og det vil derfor framgå at det ikke er markerte grenser mellom de ulike årstidsbeiter. Vi starter med våren (se figur 2), som er sesongen da kalvene fødes.

9 Lavbeiter på fattig berggrunn og kalde tørre vintre med relativt lite snø. 


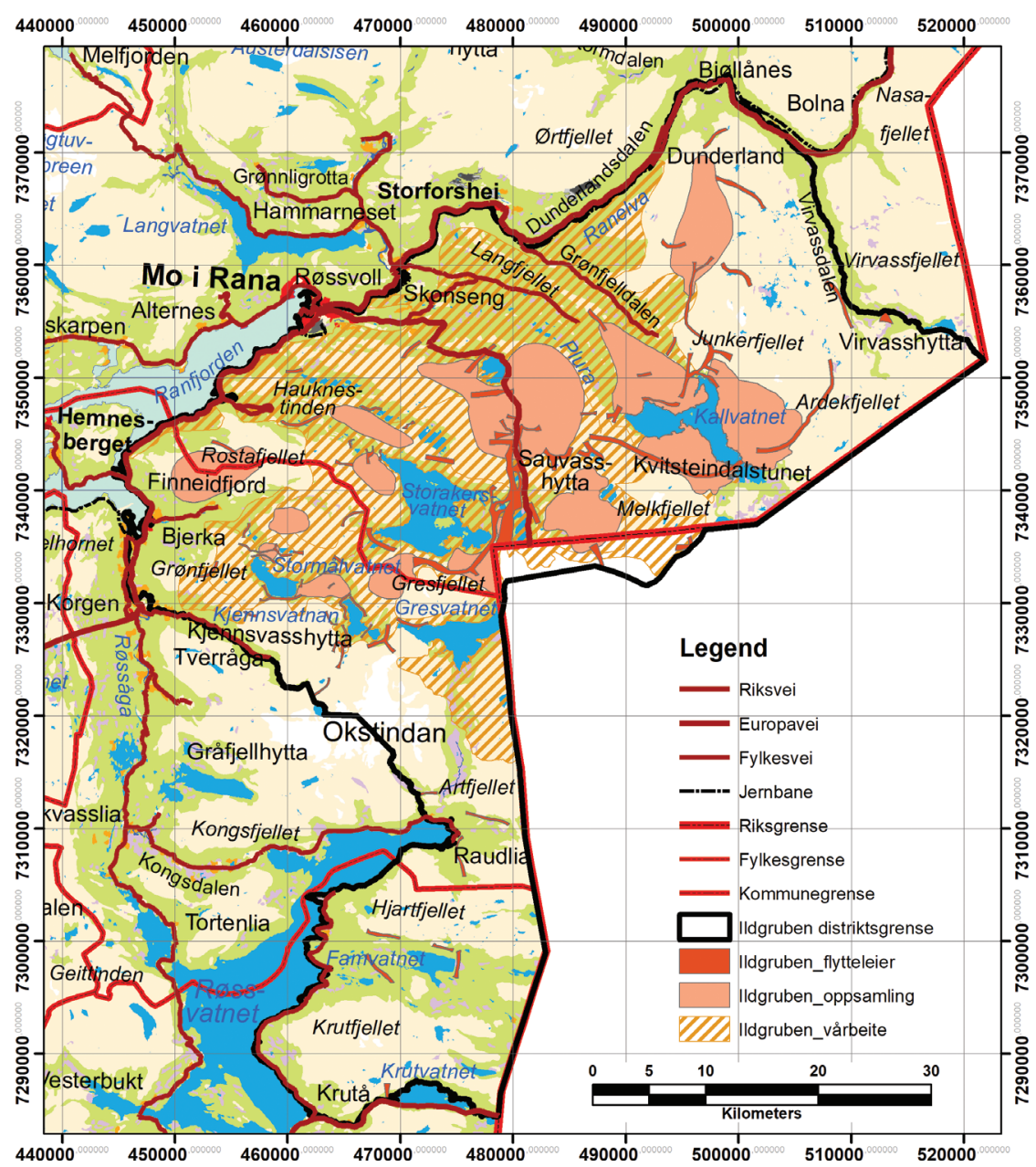

Figur 2. Ildgruben reinbeitedistrikt: Vårbeiter, oppsamlingsområder og flytteleier. (Data fra nibio. kilden.no).

Vår: Som det går fram av figuren dekker vårbeitene med kalvingslandet store deler av de sentrale delene av distriktet. I tillegg til beiteland er flytteleier og oppsamlingsområder viktig naturgitt infrastruktur i reindrifta. Oppsamlingsområdene er landskapsstrukturer som bidrar til å samle reinen i samlet flokk før organisert flytting til et annet område.

Vi kan merke oss at vårbeiteområdene omkranser store innsjøer. I dag er de fleste av disse regulert ved vannkraftutbygging. Ildgruben mistet i perioden 1950-1980 rundt $60 \mathrm{~km}^{2}$ av det viktigste beitelandet sitt i forbindelse med oppdemming av flere innsjøer. Dette var bl.a. store gressmyrer 
i de lavereliggende områdene rundt disse vannene. Som en følge av disse utbyggingene og dette arealtapet har fjellbjørkeskogen (350-60o moh.) fătt en økende betydning for Ildgruben reinbeitedistrikt. Reinen har etter disse utbyggingene måttet trekke høyere til fjells for å kalve. Flokken blir da mer spredt under kalving og blir mer utsatt for rovviltskader.

Sommer: Man bruker de samme områdene som under kalving til sommerbeiter, men også noen områder lenger sør (Ildgruben, 2017), se figur 3 . Det er da viktig å være oppmerksom på at reinen fra vår til sommer følger «våren i beitet», og at den på høgsommeren gjerne står på snøfonner og breer i høgfjellet om dagen for å unngå insekter, men trekker ned i frodige fjelldaler for å beite om natta.

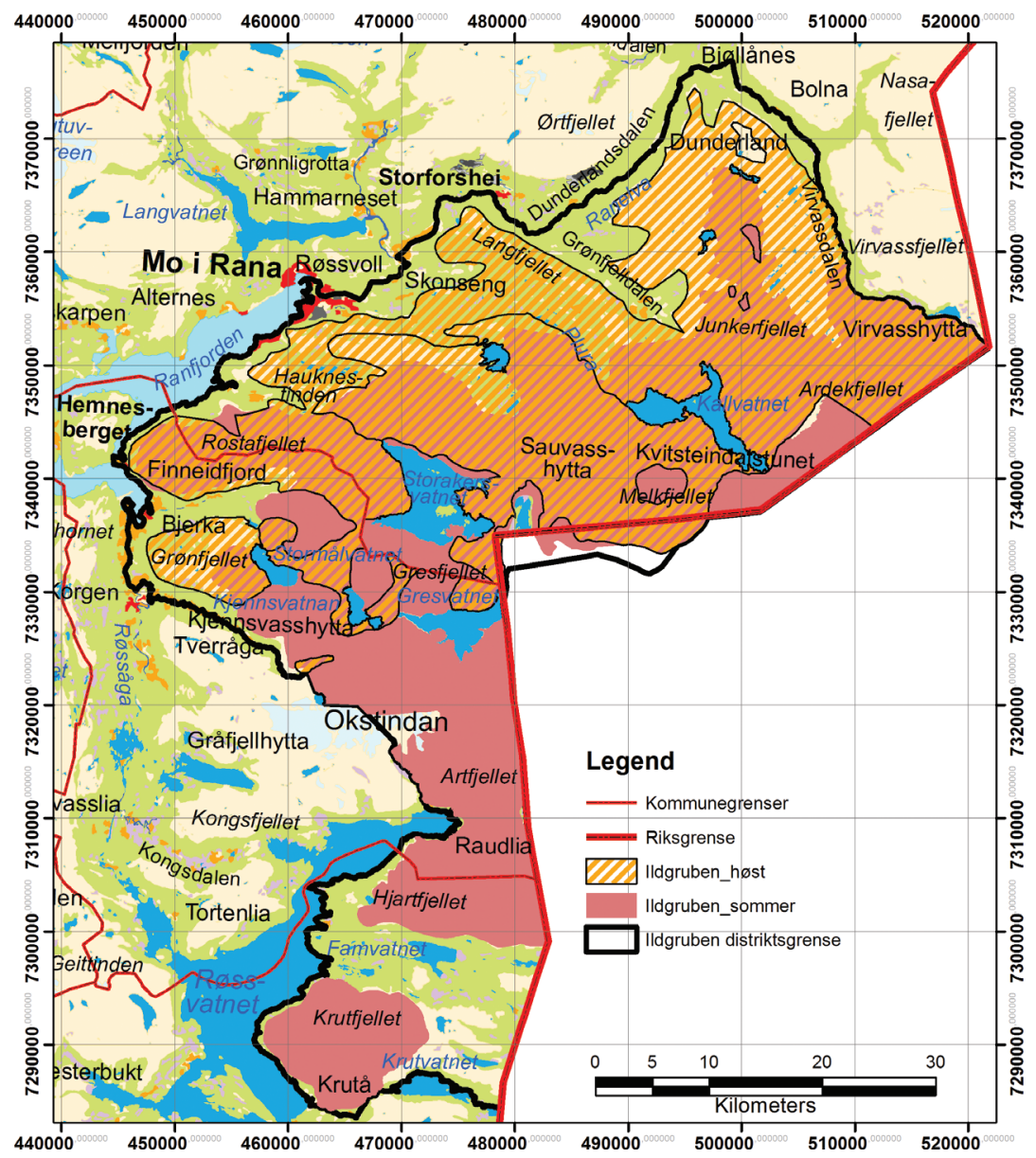

Figur 3. Ildgruben reinbeitedistrikt: Sommer- og høstbeiter. (Data fra nibio.kilden.no). 
Høst: I tillegg til vårbeiter gjorde også de store vannkraftutbyggingene viktige høst- og tidlige vinterbeiter utilgjengelige. De sentrale høstbeiteområdene finnes omkring slakteanlegget i Tverrvatnet, jf. også figur 5 (øverst i figuren). Slaktesesongen begynner med førbrunstslakt i perioden 1.-20. september. Dette anlegget fungerer som «navet» i arealbruken, da all rein er innom anlegget på høsten.

Vinter: I perioden 1985-2005 hadde distriktet vinterbeiter i Sverige i samsvar med den norsk-svenske reinbeitekonvensjon. ${ }^{10}$ På grunn av ufullførte forhandlinger om ny konvensjon har rettstilstanden for grenseoverskridende reindrift vært uavklart siden 2005, da den gjeldende konvensjonen utløp (Ravna, 2010). For Ildgruben har dette ført til at distriktet ikke lenger har beiterett i Sverige. Beitene i Sverige var svært viktige for distriktet. De mest brukte vinterbeitene nå er i nordre del av distriktet. I forhold til tap av rein til fredet rovvilt prøvde distriktet tidligere å forebygge tapene ved gjeting og flytting av reinflokken. Denne flyttingen har nå blitt umulig pga. de stengte grensene mot Sverige. Med dagens situasjon og rovdyrpress er det begrenset $\mathrm{i}$ hvilken grad tapene kan forebygges når reinen beiter på fritt land.

\section{Kumulative effekter av inngrep}

For Ildgruben er det spesielt to typer naturinngrep som over tid har medført omfattende kumulative effekter: vassdragsreguleringer og veiutbygging. De store vassdragsreguleringene på 1960-tallet var begrunnet i den lokale industriens behov for sikker kraftforsyning og er siden fulgt opp av tilleggsreguleringer. I tillegg til det direkte fysiske tapet av beiteland har vassdragsreguleringene ført til en serie indirekte og kumulative effekter: Disse omfatter både forandringer i driftsmønsteret, økt press på andre beiteområder og vanskeliggjort flytting mellom de ulike beiteområder. Det er også bygd $100 \mathrm{~km}$ anleggsveier. Disse er åpne for allmenn ferdsel og bidrar til omfattende press på distriktet ved å åpne områder som tidligere var lite tilgjengelige for folk flest, noe som har medført sterkt økende hyttebygging og rekreasjonsbruk.

Reinbeitekonvensjonen av 1972 ga Ildgruben reinbeitedistrikt rett til reinbeite i Sverige. Dette var områdene i Vindeln kommun, Ramsele og Granö i Västerbottens län, samt et område i Storuman kommun i Västerbottens län mellom riksgrensen, Överuman og Mjölkbacken. 


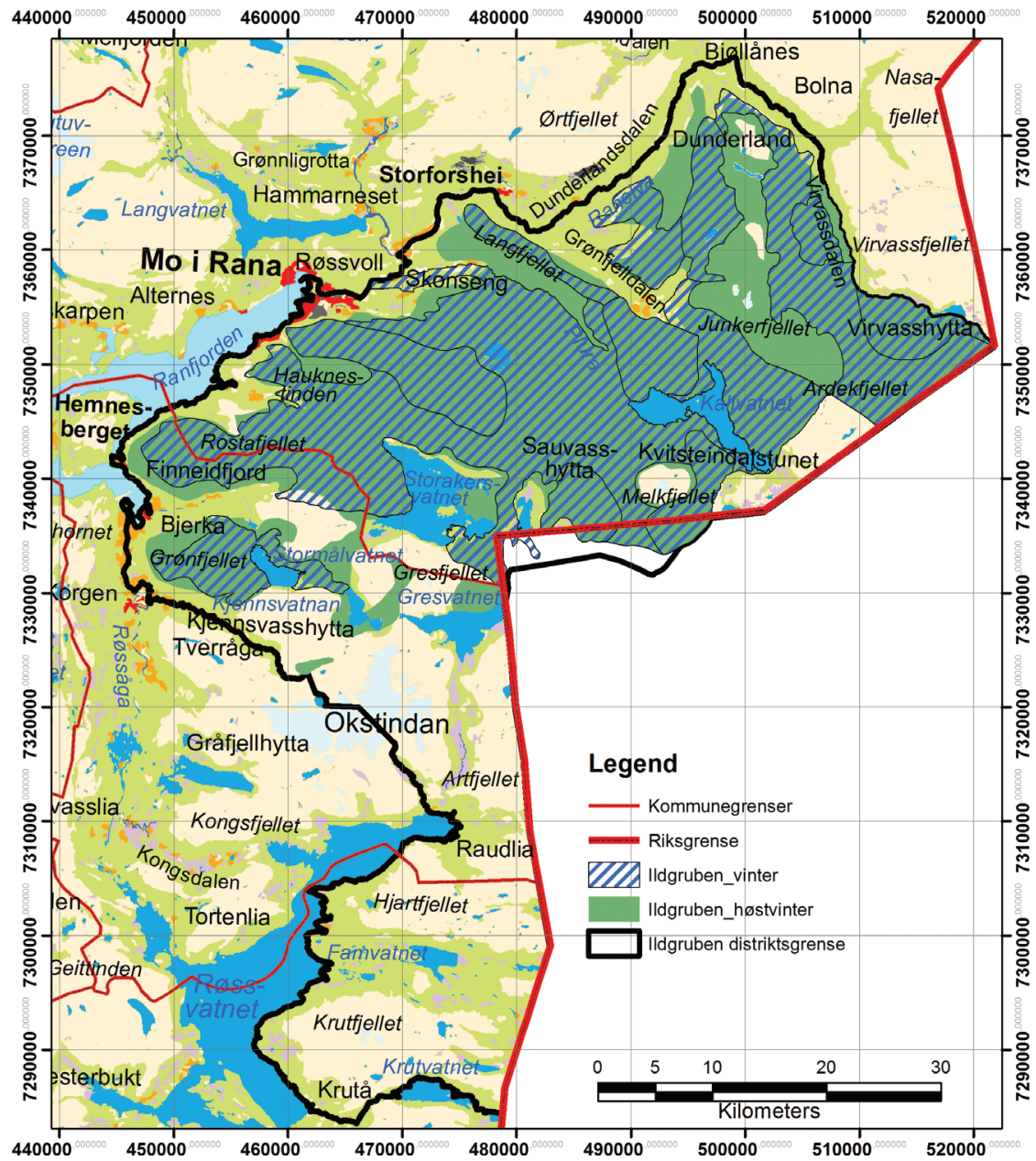

Figur 4. Ildgruben reinbeitedistrikt: Høstvinter- og vinterbeiter. (Data fra nibio.kilden.no).

Annen veiutbygging har også bidratt sterkt til å åpne fjellet for allmennheten. Det er i alt 109,3 km fylkesvei og europavei innenfor distriktet (Rasch, 2017, s. 25). E12 fra Mo i Rana til Sverige deler distriktet omtrent i to. Veien ble oppgradert og asfaltert på 1970-tallet, fornyet på 1990-tallet, og i 2006 sto den nesten fire km lange Umskardtunnelen ferdig (Rasch, 2017, s. 24). Det går svært viktige trekk- og flyttleier fra sørøst (nord og sør for Stor-Akersvatnet), over Umskardet og mot fjellryggen over Tverrvatnet. Det er viktige oppsamlingsområder nord for Umbukta og på begge sider av Tverr- og Rauvatnet. Flytt-, trekkleier og oppsamlingsområder er markert på arealbrukskartet, se figur 5 . 


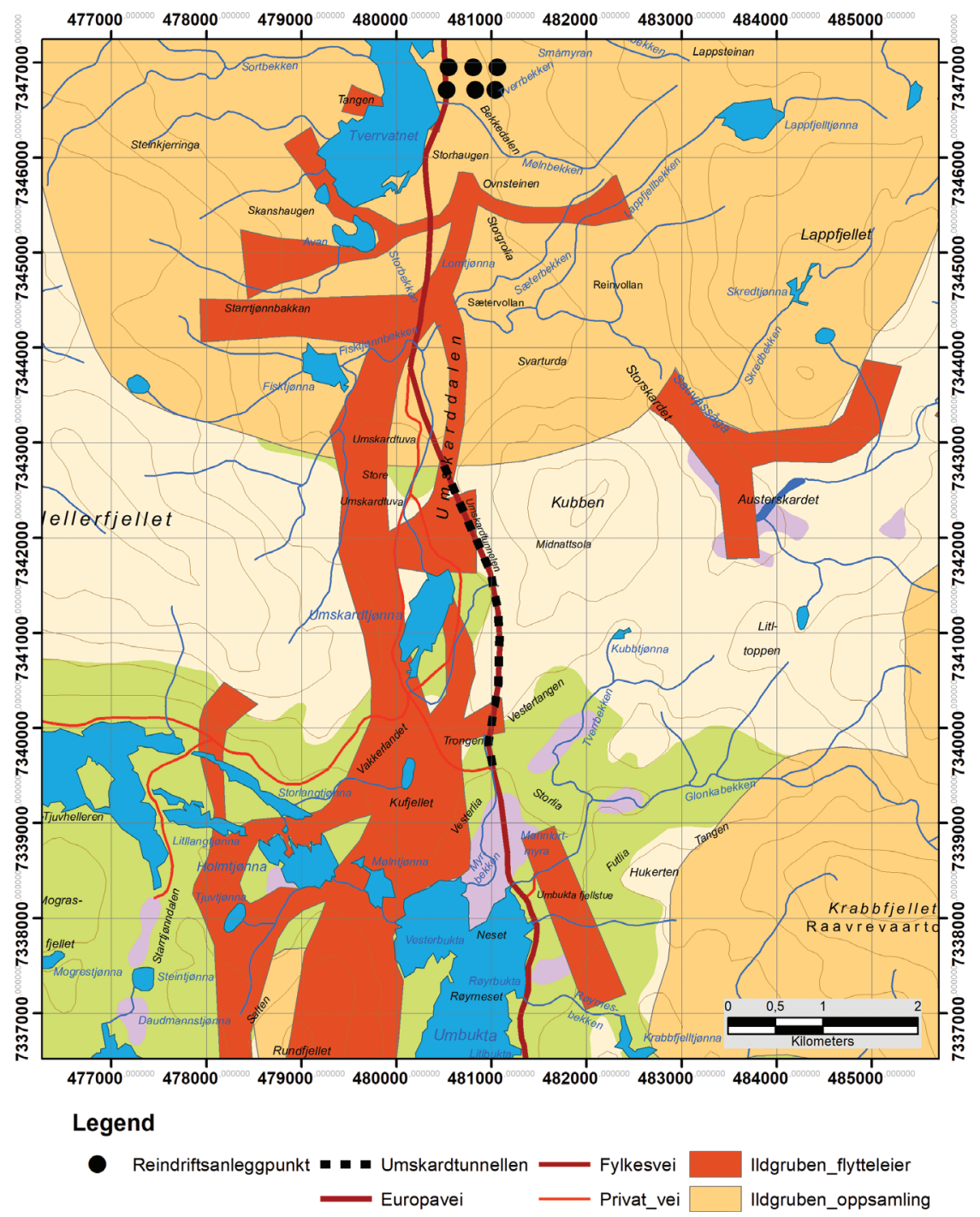

Figur 5. Området Raudvatn-Tverrvatn-Umskardet-Umbukta. Trekk- og flyttleier samt oppsamlingsområder. (Data fra nibio.kilden.no).

Tuneller kan være fordelaktige for reindrifta hvis reinen kan passere over «tunelltaket» (Riseth et al., 2016). På figuren ser vi to flyttleier som passerer slik. Umskardtunellen har likevel blitt en ulempe. Da den ble bygd, var avtalen med reinbeitedistriktet at gammelveien over Umskardet skulle tilbakeføres til naturen. Kommunen har imidlertid trenert dette tiltaket da de ser nytten av gammelveien som beredskapsvei dersom 
tunellen må stenge (vedlikehold/ulykker o.l.). Dermed ligger den asfalterte veien over Umskardet der fortsatt. Den brukes i stor grad til friluftsliv, noe som medfører store forstyrrelser på reinen.

Det ligger et dobbelt dilemma i dette. For det første er det samfunnsmessig viktig med beredskap for situasjoner der tunellen blir stengt. For det andre er friluftslivsaktiviteter viktige i et folkehelseperspektiv. Begge disse forholdene kan skape store omdømmeproblemer for reindrifta når de ønsker veien tilbakeført til naturen. Det er en betydelig pedagogisk utfordring å få allmennheten til å forstå at forstyrrelser fra friluftslivsaktiviteter over Umskardet kan ha svært skadelig virkning på reinens arealbruk i perioden oktober-februar.

Hyttebygging: Rasch (2017) har gitt en oversikt over samlet inngrepsbelastning på reindrifta i Ildgruben. En hel serie hyttefelt er direkte knyttet til anleggsveier og hovedveien E12. I alt 12 hyttefelter ble etablert fra 1960- og 70-årene fram til årtusenskiftet. De rommer 763 hyttetomter og dekker i alt $25 \mathrm{~km}^{2}$ (Rasch, 2017, s. 21). Det har dessuten vært en kontinuerlig oppgradering av standarden av de 1700 hyttene innenfor distriktet de siste årene. Hyttene er blitt fullisolert, fått innlagt strøm, innlagt vann og internett. Dette har ført til endring i bruken fra noen få dager på høsten og i påskeferien til helårsbruk. Dermed oppstår det kontinuerlige forstyrrelser på reinen gjennom hele driftsåret. Spesielt småviltjakt med hund er problematisk; den starter samtidig som distriktet skal samle til slakt, og fører også til at brunsten blir forstyrret.

Det største feltet er Mogressfjellet med 233 hytter i tillegg til at det ligger enkelthytter langs E12 på hele strekningen Mo i Rana-Umbukta. Det ligger et nyetablert hyttefelt med 112 hytter ved E12 i Umbukta. Det er også aktivitet rundt Umbukta fjellstue, som er et vertshus med overnattingstilbud. Her er det stadig økende tungtrafikk og mye helgeutfart. På barmark er det trafikk Umbukta-Umskardet-Mogressfjellet langs en anleggsvei. På vinterføre er det snøskutertrafikk fra et stort skutergarasjeanlegg i Umbukta til Mogressfjellet.

Friluftsliv: I tillegg er det et populært område for småviltjakt og toppturer på ski gjennom store deler av vinteren. Til sammen bidrar dette til å skape unnvikelsessoner langs inngrepene. Disse er anslått til å være i størrelsesorden 250 meter, på hver side utover selve inngrepet. I tillegg til dette går Nord- 
Norges største turrenn på ski rett igjennom reinbeitedistriktet fra Umbukta til Mo i Rana, vanligvis på lørdag før palmesøndag. Tidligere ble løypetraséen tråkket opp av kommunen når «sola begynte å varme» fra slutten av februar og utover. Dette var avtalt med reinbeitedistriktet. I 2016 solgte imidlertid Rana kommune en gammel tråkkemaskin billig til driver av Umbukta fjellstue. Han ønsket å preparere løyper over Umskardet fra snøen kommer om høsten og hele vinteren. Dette uten å konferere med reindrifta.

Denne aktiviteten ville ført til svært skadelige forstyrrelser på reinens arealbruk og reindrifta. På grunn av medieoppslag i lokalavisa, fikk reindrifta dårlig rykte/omdømme i lokalsamfunnet da de setter foten ned for løypekjøring fram til reinen har passert gjennom området (slutten av januar). Dette medieoppslaget førte videre til et betydelig antall innlegg i sosiale medier. De fleste av disse innleggene var negative til reindriftsnæringa.

\section{Klimaendring}

De pågående klimaendringene, kombinert med reinbeitedistriktets nærhet til kysten, har de siste vintrene ført til hyppige vekslinger mellom snøvær og perioder med plussgrader og regn. Dette fører til dyp tung snø og/eller islag som reinen ikke klarer å grave seg igjennom. Klimaendringene, kombinert med betydelige tap av rein til rovvilt i noen av de sørlige delene av distriktet, har ført til at distriktet har måtte praktisere fôring av reinen gjennom vinteren. Både for å sikre overlevelse av reinen samt for å forsøke å redusere de store tapene av rein til rovvilt.

Et eksempel på utfordringene til distriktet kan være vinteren 2017/18. På grunn av vanskelige snøforhold måtte distriktet starte med tilleggsfôring av reinflokken tidlig i januar 2018. I begynnelsen av mars var det tilfredsstillende beiteforhold i sørvestlige deler av distriktet, og de flyttet deler av reinflokken til dette området. Da flere reinsimler ble funnet drept av jerv, valgte reineierne å flytte reinflokken bort fra disse beitene etter bare en uke, og tilleggsfôring av reinen ble gjenopptatt. Vinteren 2020 ble både Ildgruben, distrikter i Troms og det meste av reindrifta i Finnmark rammet av ekstraordinært store snømengder som ville førte til massedød av rein hvis ikke spesielle katastrofetiltak med statsfinansiert støtte til foring av rein var blitt iverksatt. 


\section{Oppsummering}

På grunn av faktorene vi har gjennomgått, har Ildgruben reinbeitedistrikt mistet muligheten (fleksibiliteten) til å variere bruken av beitene. Viktige beiter er neddemmet og nedbygd (anleggsveier og hytter), de er ikke tilgjengelige på grunn av manglende avtale med Sverige og på grunn av rovdyrtrykket. I andre områder vil ikke reinen oppholde seg pga. forstyrrelser fra menneskelig aktivitet. På toppen av dette blir vinterbeitene med økt hyppighet utilgjengelige på grunn av ustabilt klima. Reinbeitedistriktet har derfor svært utfordrende driftsforhold og usikker framtid dersom ikke tilleggsfôring av reinen vinterstid skal blir en permanent del av drifta.

\section{Gielas reinbeitedistrikt}

Distriktet ligger i indre Sør-Troms og nordre Nordland med vinterbeiter i Sverige; mellom Ofotfjorden og Ofotbanen i sør, E6 og Astafjorden i vest, Sjøvegan og Sætermoen i nord, Sørdalen, svenskegrensen og Torneträsk ${ }^{11}$ i øst, se figur 6.

\section{Beitebruk og inngrep}

Vår: Figur 6 angir vårbeiter i daler og lavereliggende områder over store deler av distriktet, men distriktet framhever selv de nordre delene av distriktet som viktigst (Riseth \& Johansen, 2019). Setermoen skyte- og øvingsfelt utgjør en betydelig del av det beste kalvingslandet, og man kalver fortsatt i skytefeltet. Forsvaret er ved dom pålagt en måneds aktivitetsforbud. Faste datoer er imidlertid meget krevende for reindrifta, spesielt i dagens klima. Distriktet har derfor også måttet ta i bruk kalvingsland på de to halvøyene vest for E6. Foruten høye tinder som er viktig sommerland, har begge halvøyene lavereliggende fjellområder med lite snø. Disse er attraktive kalvingsområder og er særlig viktige i seine vårer. Disse lave fjellområdene er også

$11 \quad$ Ikke med på kartet. 


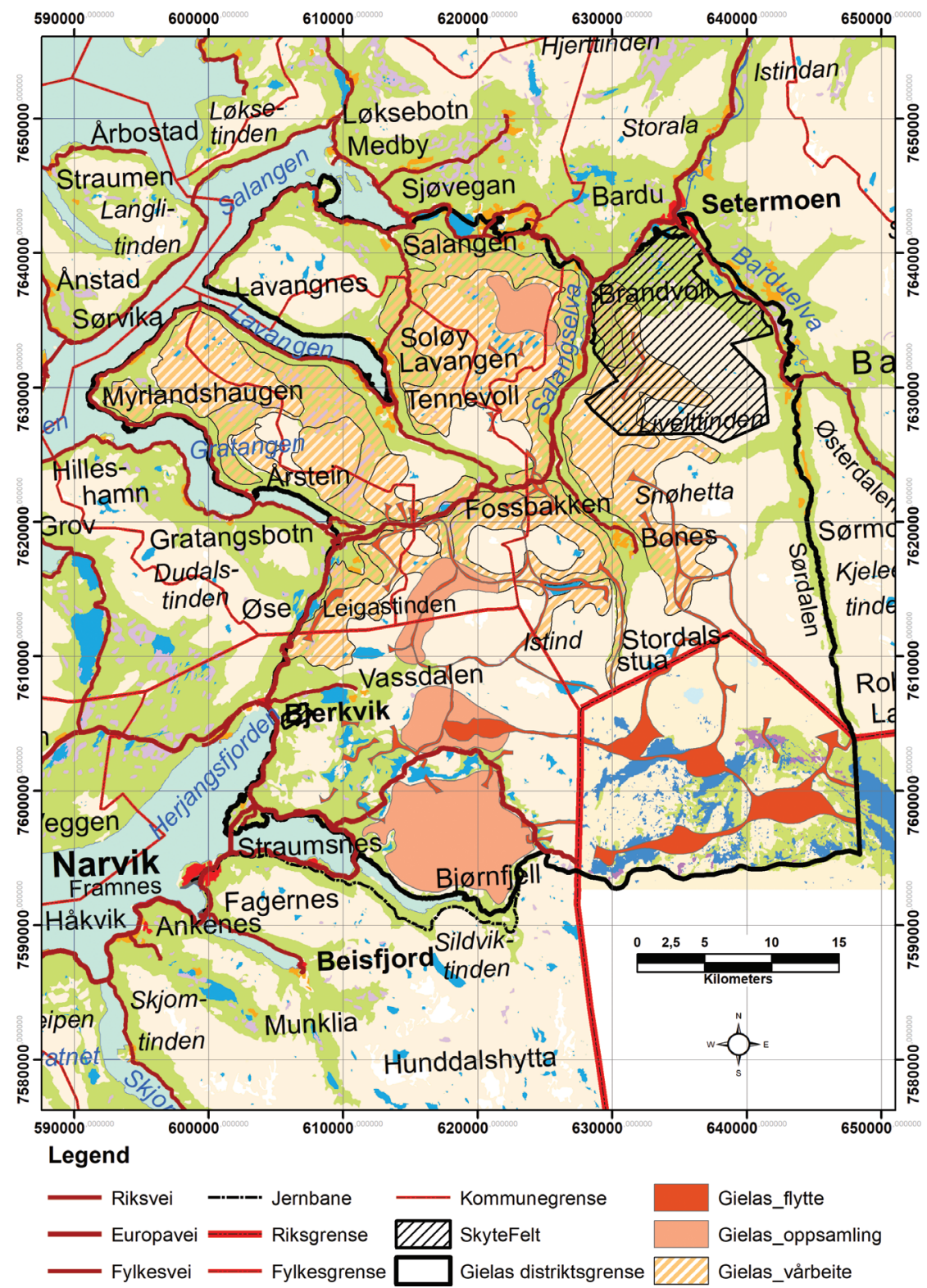

Figur 6. Gielas reinbeitedistrikt: Vårbeiter, oppsamlingsområder og flytteleier. (Data fra nibio. kilden.no). 
attraktive hytte- og utfartsområder. På grunn av omfanget av menneskelig aktivitet i utfartstida om våren, trekker reinen i helgene ut av området. Den må føres tilbake på ukedagene når det er liten aktivitet knytta til hyttene. Reinen kan trekke helt over Salangsdalen og E6. Østsida har høyere fjell og dermed seinere vår, og er dermed mindre gunstige kalvingsområder. Dette gjør også reinen mer sårbar under kalvinga da simlene blir mer stressa. Dersom simler blir forstyrret like etter kalving, f.eks. av skigåere/hunder, kan det føre til at simla forlater kalven. Når reinen er mer i bevegelse, blir den også mer utsatt for rovdyr, spesielt ørn.

Sommer: Hyttefeltene har gjort det nødvendig å flytte østover tidligere enn ønskelig. Hovedsommerlandet er på østsida av E6, dvs. fjellområdene innover mot svenskegrensa, men det blir igjen en del rein igjen på vestsida. På sommeren er reinen mye forstyrra av fotturisme og turer til fiskevann. Den nyetablerte $420 \mathrm{kV}$-kraftlinja (med «monstermaster») går mer eller mindre parallelt med E6, men utgjør likevel en barriere. Ved kryssing av E6 må flokken drives aktivt av reindriftsutøverne. En del rein snur tilbake når de møter kraftlinja og kommer feil i forhold til trekkretninga. Det kreves ekstraarbeid å hjelpe disse dyrene på rett kurs.

Høst: Figur 7 viser at det er høstbeiter over store deler av distriktet, men hovedtrekket om høsten er først sørover, så østover. Reinen forholder seg ulikt til inngrep/forstyrrelser som kraftlinjer om den er $p a ̊$ trekk, under beiting eller når den drives. Når reinen er på trekk, som til sommerlandet etter kalving, kan den passere tilsynelatende uanfektet under ei kraftlinje. Den vil vanligvis ikke gå under ved beiting - når den er på vakt, blir den lett skremt. Vind, regn og dårlig vær fører til sterkere støy fra kraftledningene, og reinen blir mer stressa. Driving av rein under aktiv flytting er en stressituasjon for reinen, og den er da ekstra sårbar for ytre påvirkning. Driving er også vanskeligere på barmark enn på snø. Dette er ekstra vanskelig når to barrierer skal forseres etter hverandre. E6 og kraftlinja ligger som nevnt slik til. Under inndriving til førbrunstslakt i gjerdeanlegget 


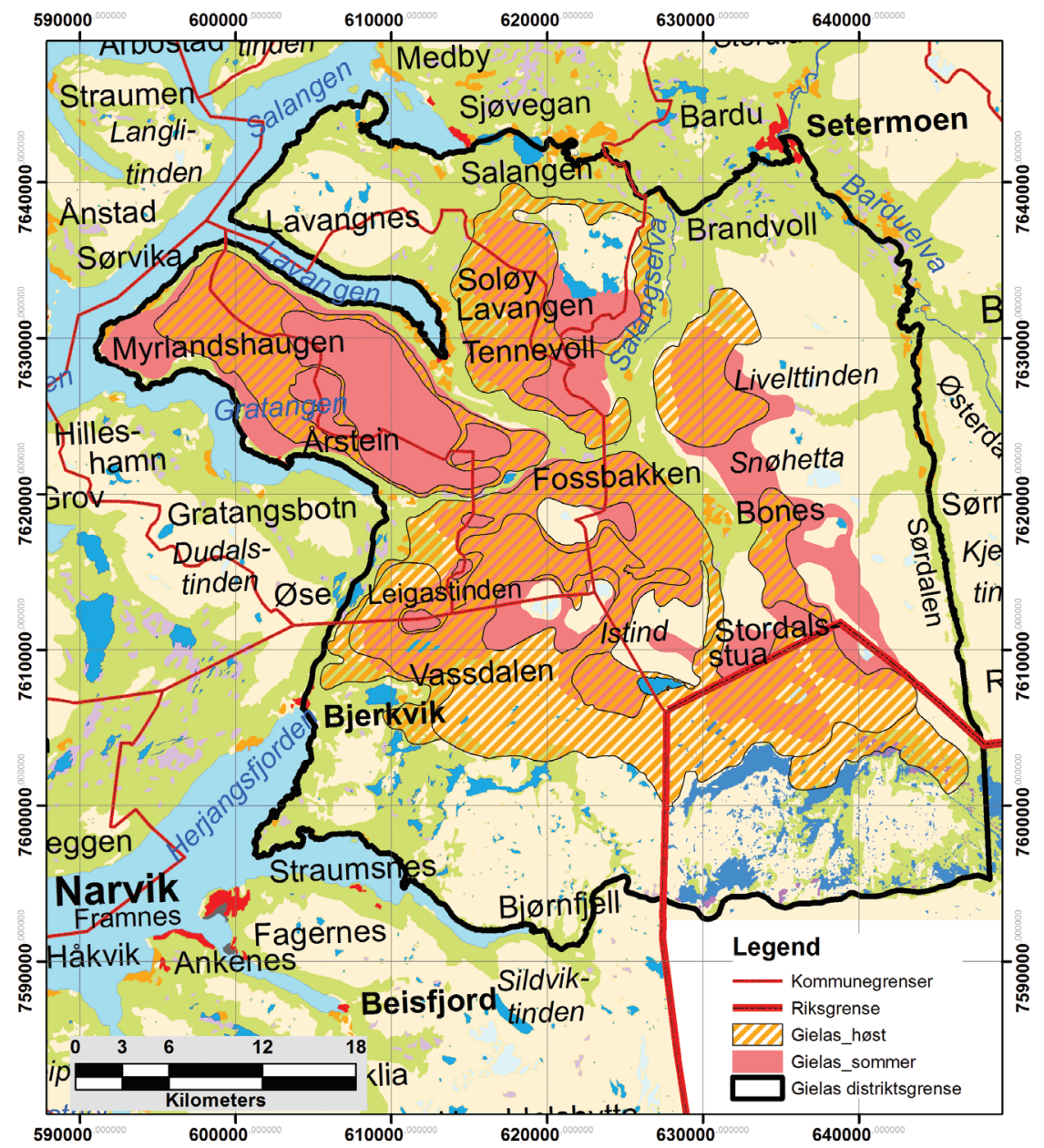

Figur 7. Gielas reinbeitedistrikt: Sommer- og høstbeiter. (Data fra nibio.kilden.no).

på Bukkemyra ${ }^{12}$ i september 2016 mista distriktet delvis kontrollen over reinen. Dette betød både ekstrabelastning på dyra og omfattende merarbeid for reineierne. Konsekvensen er at dette anlegget ikke har vært brukt til uttak av slaktedyr siden 2016 (Riseth \& Johansen, 2019).

12 Ved E6 på Gratangsfjellet. 


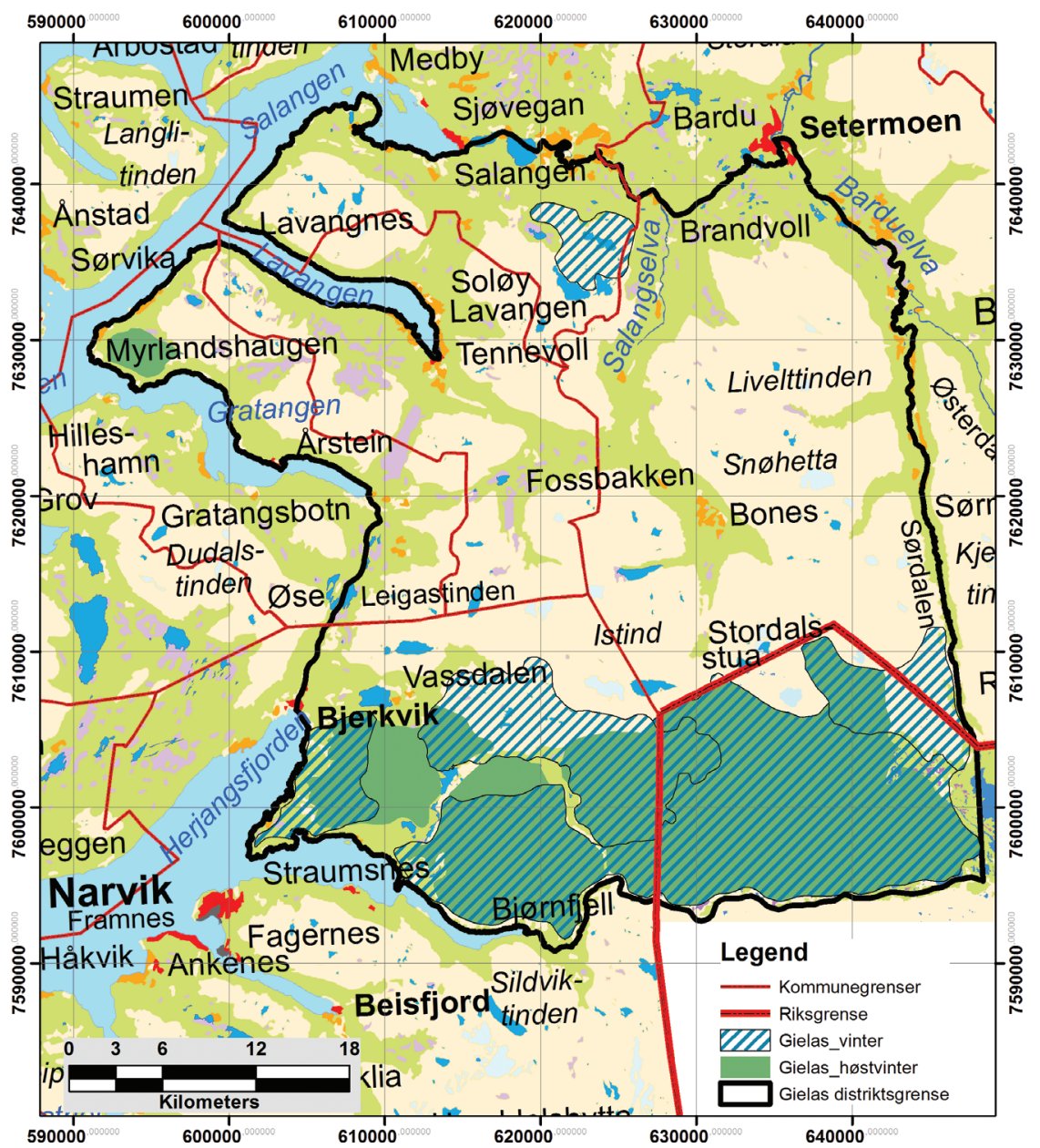

Figur 8. Gielas reinbeitedistrikt: Høst-vinter- og vinterbeiter. (Data fra nibio.kilden.no).

Lengst sør i distriktet, i Narvik kommune, ble ei rekke større vann regulert allerede $\mathrm{i}$ mellomkrigstida ${ }^{13}$ for å sikre kraftforsyninga til Narvik by og Ofotbanen ${ }^{14}$ som transporter jernmalm fra Sverige til utskiping i Narvik, se figur 8. De regulerte vannene danner en barriere som på 1980-tallet ble forsterket av ny mellomriksvei (nå E1o) ${ }^{15}$ og etter

\footnotetext{
13 Nygård kraftverk åpnet 1932.

14 Åpnet i 1902.

15 Åpnet 1984.
} 
årtusenskiftet av Nygårdsfjellet vindpark. ${ }^{16}$ Både Ofotbanen og E1o har dessuten lagt grunnlaget for omfattende hyttebygging. Et betydelig antall bygninger fra Ofotbanen ble tidlig på 1900-tallet tatt i bruk til fritidsformål, og Bjørnfjellplatået ${ }^{17}$ nær jernbanen har siden utviklet seg til et sammenhengende hyttelandskap, se figur 9.

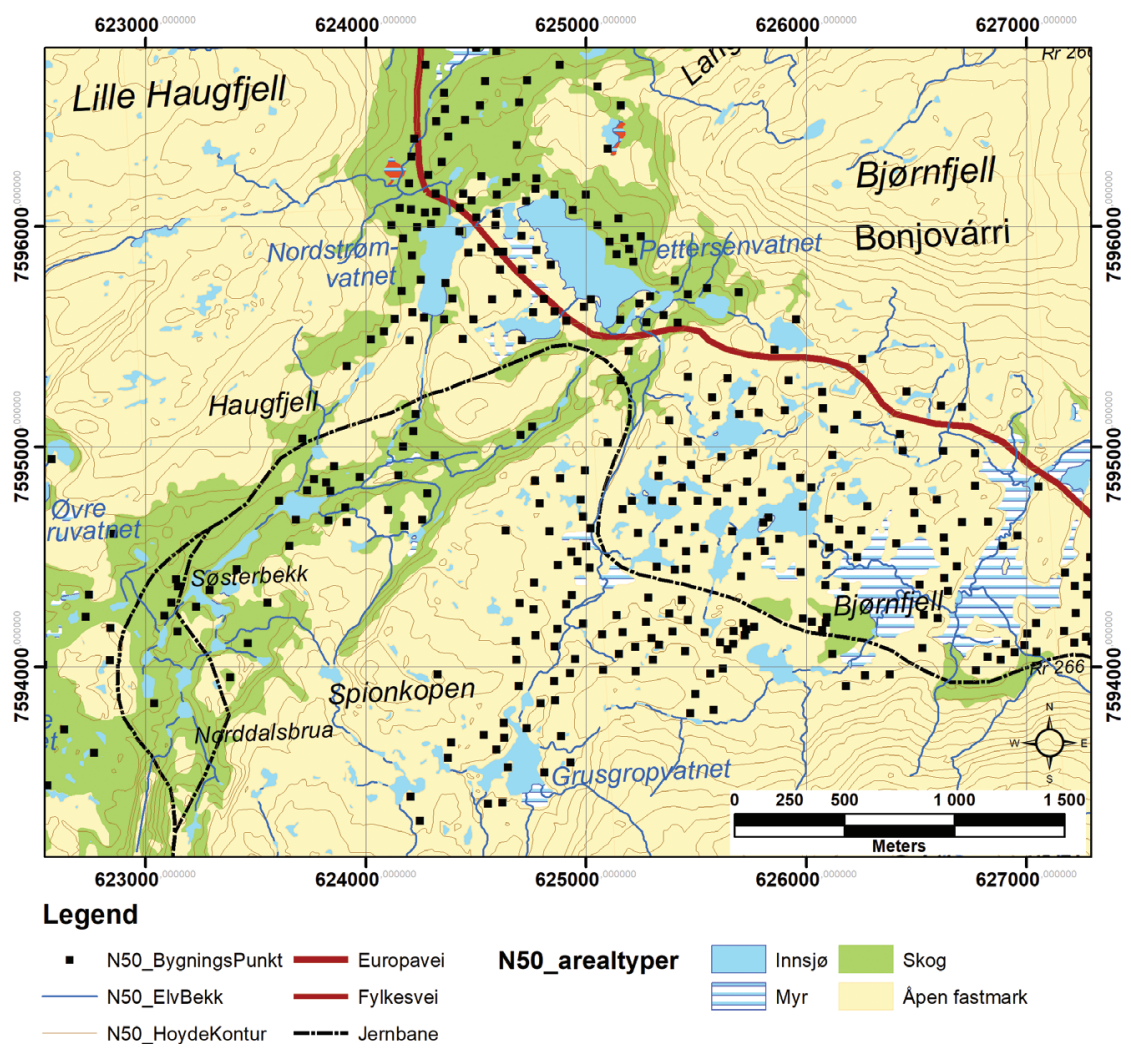

Figur 9. Hyttelandskapet på Bjørnfjellplatået er høstvinter og vinter-beite, jf. figur 8. (Bearbeidet fra Norgeskart.no).

E1o har ført til nye hyttefelter langs veien, på begge sider av det oppdemte Jernvannet. Nygårdsfjellet vindpark har i ettertid kommet midt imellom disse hyttefeltene, se figur 10. Om høsten beveger reinen seg lavt i terrenget. Den samlede barrierevirkningen av de regulerte vannene og

\footnotetext{
16 Nygårdsfjellet vindpark ble satt i drift 2006 og utvidet i 2011 (3+11 vindturbiner). https://www. nordkraft.no/kraftverk/nygardsfellet-vindpark

17 Bjørnfjellområdet har en betydelig del av (gamle) Narvik kommunes over 2000 fritidsboliger.
} 
hyttefeltene betyr at passasjen til Haugfjell er svært vanskelig. Tidligere har distriktet benyttet slaktegjerde (på Skitdalshøgda) like ved flyttleia over Nedre Jernvatnet til venstre på kartet i figur 10. ${ }^{18}$

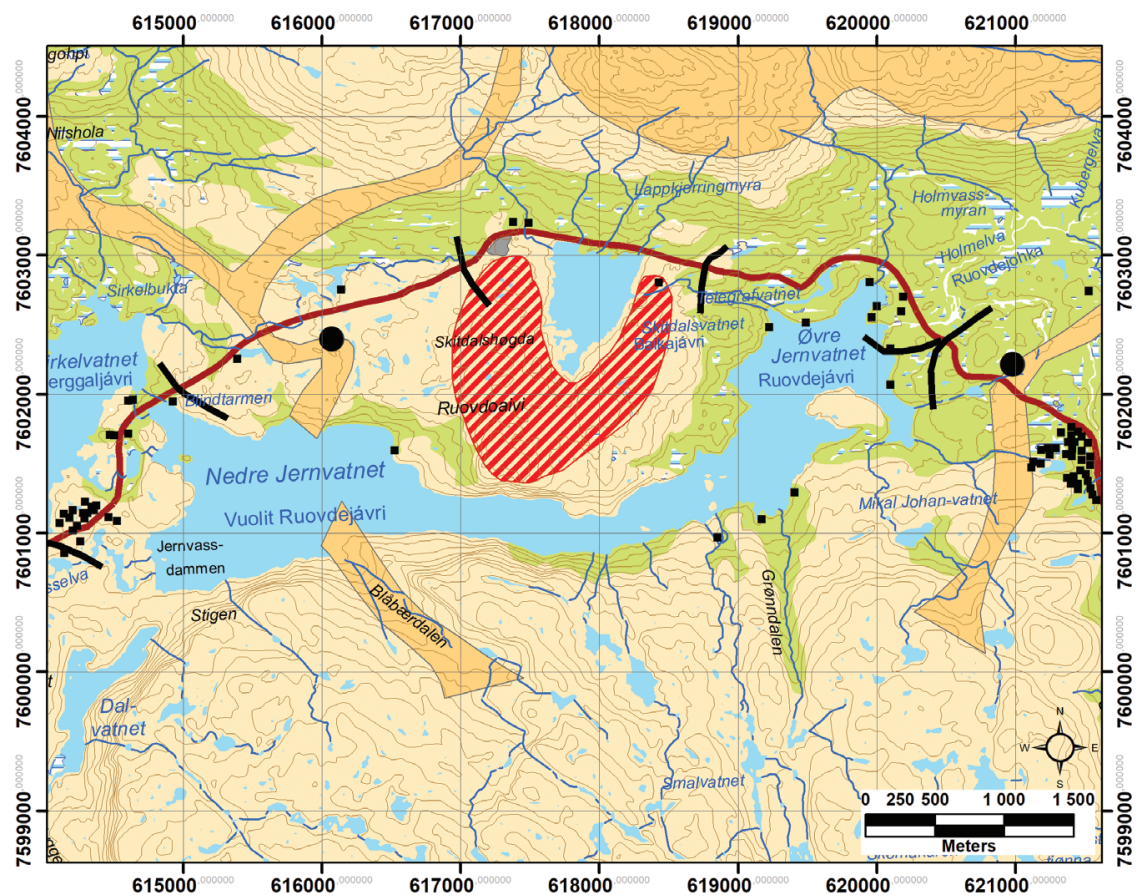

Legend

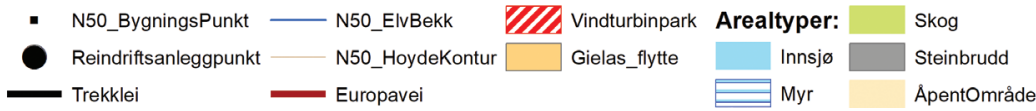

Figur 10. Nyere hyttefelt (både til venstre og høyre i bildet), Nygårdsfjellet vindpark like nord for det regulerte Jernvannet. (Data fra nibio.kilden.no).

På et offentlig seminar på Framsenteret i Tromsø i oktober 2019 bekreftet nåværende distriktsleder at den første høsten vindturbinene var kommet opp, ble reinflokken skremt og brøt ut av slaktegjerdet slik at de seinere ikke har kunnet bruke det. Den praktiske effekten av vindturbinene er at trekket stopper opp fordi reinen blir skremt, og den prøver derfor å bevege seg i andre retninger enn dit reineierne vil ha dem. For

18 Symbol for reindriftsanlegg til høyre i kartet gjelder et anlegg som er fjernet, men fortsatt ligger inne i kartet (O. J., Eira, personlig kommunikasjon, 13. april 2021). 
distriktet gir dette omfattende konsekvenser. Som nevnt kan ikke slaktegjerdet på Skitdalshøgda brukes lenger. Det kan heller ikke trekkleia til Haugfjell. På grunn av inngrepene og forstyrrelsene er det er nå gunstigst å bruke Bjørnfjell om høsten. Da er det ikke så mye folk på Bjørnfjellplatået som på våren - da er det folk overalt, både på hyttene og $\mathrm{i}$ terrenget. Dette er konsekvenser som tydeligvis «gikk under radaren» for kommunale myndigheter, i hvert fall i første omgang, se tekstboks 1.

\section{Tekstboks 1}

I forbindelse med NVEs forslag om nasjonal ramme for vindkraft ga Fellesnemda for nye Narvik kommune en egen uttalelse om at man var positiv til mer vindkraft $\mathrm{i}$ kommunen om dette kan kobles mot industri og næringsliv lokalt. Et forslag om at det i særlig grad skal tas hensyn til urbefolkningens interesser fikk kun forslagsstillers stemme (Næsje, 2019). I innspill til kommunens arealplan ble det i tillegg bl.a. foreslått nye vindturbiner både på Haugfjell (Nygårdsfjellet) og på andre kritiske lokaliteter i distriktet (Riseth, 2021a-c). Dette førte til en hissig debatt i lokale og sosiale medier med svært mange kritiske stemmer mot kommunens måte å håndtere dette på. På forsommeren 2021 organiserte en lokal gruppe av «Motvind» et innbyggerinitiativ som foreslo at man skulle si nei til vindkraft i Narvik og ikke avsette områder til vindkraft i kommuneplanen. Det ble på kort tid samlet nær 1000 underskrifter og avholdt flere offentlige markeringer (Nybakken, 2021). I september snudde ordførerens parti (Hansen, 2021), og kommunestyret sa nei til vindkraft med stort flertall (Næsje, 2021).

Vinter: På 1980-tallet og fram mot årtusenskiftet framsto Gielas som et norsk distrikt som hadde en vellykket beitetilpasning basert på den norsk-svenske reinbeitekonvensjonen av 1972 (se foran). Man kommer nå raskere inn til Sverige enn man burde. Gielas får fortsatt brukt de tidlige vinterbeitene (nærmest riksgrensen), mens man ikke har tilgang til seinvinterbeitene (lenger øst). Også i relativt gode år må det tilleggsfôres på friland. Når det er ising og vanskelige vintre, fôrer distriktet i gjerde. 
Sammen med andre inngrep har dette omfattende påvirkning på distriktets beitebruk. Det har bl.a. ført til at man har tatt i bruk Haugfjell som seinvinter- / tidlig vårbeite.

\section{Kumulative effekter av inngrep}

Det store bildet for Gielas er at inngrep og forstyrrelser fører til at reinen ikke får ro i noen av årstidene, slik at oppholdet innenfor hvert av årstidsbeitene blir forkortet. Beitebruken blir forskjøvet og kommer i ufase med både beiteutviklingen og reinens behov. Klimaendringer og økt eksponering for rovdyr forsterker de negative effektene av dette. Samlet sett fører dette til både dårlig ressursutnyttelse og merarbeid så vel som økte kostnader og reduserte inntekter.

Når det gjelder klimaendringseffekter oppsummerer distriktet at både seine vårer og tidlige høster er forbundet med betydelige ulemper. Sein vår betyr at det er gunstig å være lenger i kalvingslandet. Dette er umulig i Sætermoen skytefelt og problematisk pga. hyttefelt i resten av kalvingslandet. Jo tidligere snø om høsten, jo lenger ned i terrenget vil reinen trekke, og desto mer konflikt med regulerte vann, hyttefelt og vindturbinparken.

Med hensyn til rovdyrtap oppsummerer distriktet at pga. inngrepene er reinen mer i bevegelse og dermed mer eksponert for rovdyr, spesielt ørn. Dette bidrar til å øke tidlige kalvetap. E6 danner grensen mellom rovdyrsone (østsida) og rovdyrfri sone (vestsida). På grunn av hyttefeltene og aktiviteten i og omkring dem, trekker reinen tidligere over på østsida; det betyr større tap. Om høsten kommer man tidligere inn til Sverige, som har enda mer rovdyr - det betyr ytterlig økte tap. Sein slakting på grunn av driftssituasjonen fører til økte seine kalvetap. Alt i alt har distriktet stadige forskyvninger inn i områder med mer rovdyr gjennom halve årssyklusen.

\section{Sammenlikning og diskusjon}

Det er både likheter og forskjeller mellom de to distriktene. Vi skal ta det punktvis. 
1. Begge distriktene strekker seg over flere kommuner, men beitebruken er noe ulik.

2. For begge distriktene har utbygging av energianlegg (vassdragsreguleringer, vindkraftanlegg og kraftlinjer) ført til omfattende tap av beiteland eller blokkert flyttleier og bruk av viktige reindriftsanlegg.

3. For begge distriktene har utbygging/oppgradering av kommunikasjonsårer, i tillegg til selve inngrepene, åpnet for omfattende hyttebygging med friluftsliv som skaper betydelige forstyrrelser i sårbare perioder for reindrifta.

4. Begge distriktene har vært utestengt fra vinterbeiter i Sverige siden 2005. Mens Ildgruben har mistet disse helt, har Gielas fortsatt tilgang til tidlige vinterbeiter i Sverige. For begge distriktene har dette gjort reindrifta avhengig av mindre gode vinterbeiter og tilleggsfôring. Det har dessuten ført til alvorlige forstyrrelser i årssyklusen.

5. For begge distriktene forsterker både klimaendring og tap forårsaket av fredet rovvilt effektene av andre problemer.

Vi har også summert opp noen sentrale næringsøkonomiske data slik de kommer fram i Reindriftsforvaltningens/Landbruksdirektoratets ressursregnskap de siste 26 år, se figurene 11 og 12 . Reintallet er antallet rein før kalving, dvs. de som har overlevd vinteren. Det utgjør åpningsstatus ved starten av reindriftsåret. Utviklinga i reintallet (dersom det ikke blir alt for høyt) kan sees som en indikasjon på hvor godt man utnytter det tilgjengelige beitepotensialet. Slakteantall er den tilveksten som reineierne tar ut og skal leve av. Tapsantall er det antall rein som tapes av ulike årsaker. Tapet som oppgis av hver enkelt siidaandelsleder er et estimat basert på reineierens egne vurderinger. Den overlegent største tapsposten er rein som tas av fredet rovvilt. Det utgjør vanligvis over 90 prosent av tapene, men er ofte vanskelig å dokumentere. ${ }^{19}$ Andre årsaker er sykdom og ulykker (påkjørsler). Forholdet mellom slakting og tap er viktig. Blir tapene for høye blir det for lite å slakte av 
og leve av, og det blir også vanskelig å bygge opp flokken slik man ønsker (se for øvrig kapittel 8).

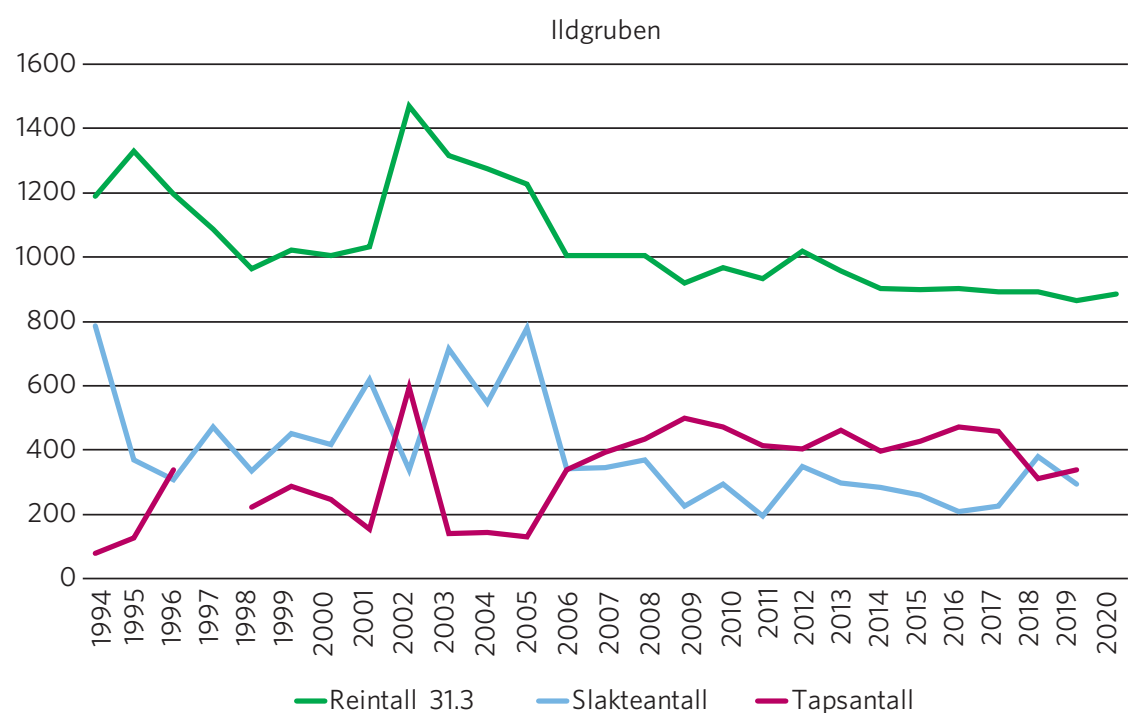

Figur 11. Ildgruben. Reintall (i vårflokk), slakteantall og tapstall 1994-2020. (Landbruksdirektoratet, 2015-2020; Reindriftsforvaltningen, 1995-2014).

Ildgruben har ligget over øvre reintall på 900 rein i første del av perioden. Slakteantallene er høye fram til midt på 20oo-tallet, mens tapstallene er relativt lave i denne perioden. Det er tydelig at noe skjer midt på 200o-tallet med halvering av slakteantallene i forhold til nivået før 2006 og mer enn dobling av tapsnivået. Dette har holdt seg siden. Rasch (2017) har analysert næringsøkonomiske data og kommet til at de samlede effektene av inngrepene ikke kan være så store siden slaktevekter osv. ikke tyder på at distriktets bæreevne er redusert. Vi anser at forfatteren gjør en alvorlig feil med å overse at distriktet i halvannet tiår har vært avhengig av tilleggsfôring til en kostnad av flere hundre tusen kroner årlig. Selv om en betydelig av dette dekkes av staten, ${ }^{20}$ er distriktet utvilsomt utsatt for omfattende tap av resiliens og økende sårbarhet. Dette må sees i sammenheng med utviklinga i tiårene før.

\footnotetext{
20 Distriktene får etter nærmere regler dekt nødvendige forings- og transportkostnader av staten (se Forskrift for Reindriftas Utviklingsfond, 2019; Sluttprotokoll fra reindriftsavtaleforhandlingene, 2019).
} 


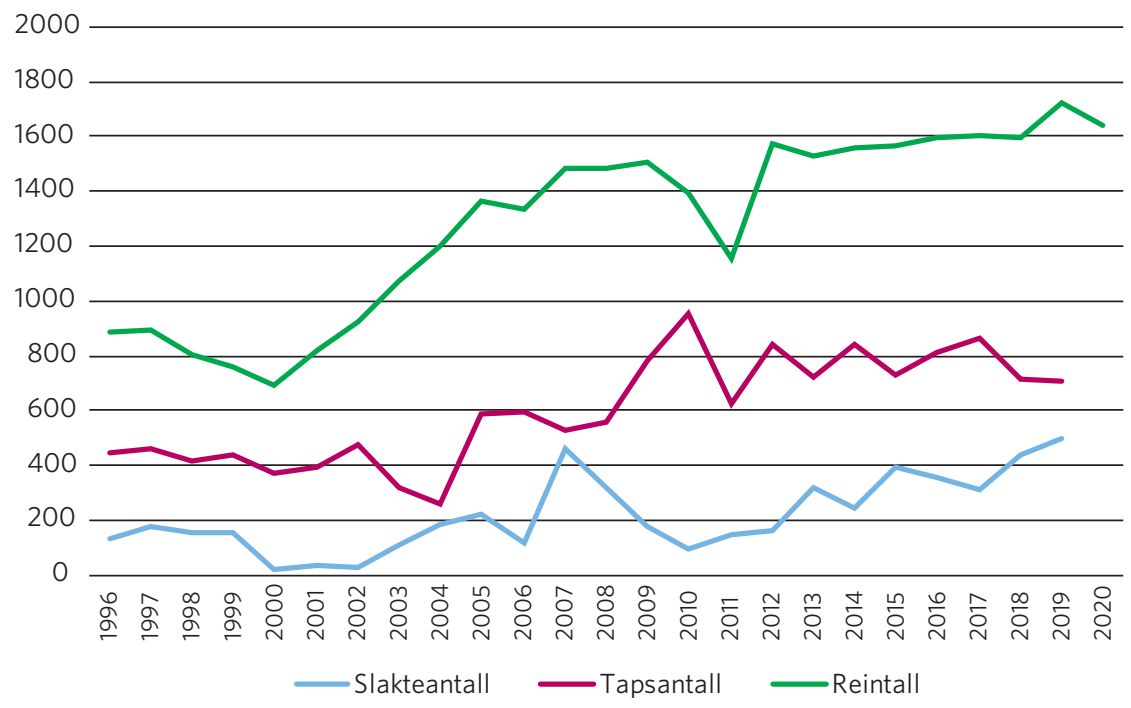

Figur 12. Gielas. Reintall (i vårflokk), slakteantall og tapstall 1994-2020 (Landbruksdirektoratet, 2015-2020; Reindriftsforvaltningen, 1995-2014).

Gielas har hatt et reintall betydelig lavere enn fastsatt øvre reintall (2250 rein) gjennom første halvdel av perioden, men har økt siden årtusenskiftet og er nå ganske stabilt på relativt høyt nivå. Tapene har imidlertid vært meget høye i hele perioden, og er gjerne dobbelt så høye som slaktetallene. Når reintallet likevel øker, blir det totalt blir mer å slakte og leve av.

I direkte sammenlikning mellom de to distriktene er det interessant å vurdere effekten av problemene som følger av manglende reinbeitekonvensjon siden 2005. For Ildgruben synes det som det fullstendige tapet av vinterbeitene i Sverige har fătt dramatiske utslag og snudd forholdet mellom tapsantall og slakteantall. For Gielas, som enda har en del vinterbeiter i Sverige, har ikke situasjonen skiftet like dramatisk, da tapene har vært meget høye hele perioden. Sannsynligvis kan dette skyldes høyere rovdyrpress i Troms enn i Nordland.

Når vi ser på sumeffektene av inngrep, er det betegnende at begge distriktene har en utvikling der en serie inngrep over en rekke tiår gradvis, men langsomt endrer tilpasningssituasjonen for reindrifta. For Ildgruben er sammenhengen mellom vassdragsutbygging, vegbygging 
og hyttefeltutbygging godt dokumentert av Rasch (2017). For Gielas har man et liknende utviklingsforløp på Bjørnfjell og Nygårdsfjellet over en enda lengre tidsperiode. Her er utviklinga delt mellom Bjørnfjell og Nygårdsfjellet. På Bjørnfjell er hyttefeltene en direkte følge av Ofotbanen. NSB hadde egne skitog til Bjørnfjell allerede på 1920-tallet, mens det var mellomriksvegen (nå E10) midt på 1980-tallet som åpnet Nygårdsfjellet.

Som påpekt av Rørholt (2009, s. 28) har reindrifta en betydelig evne til å omorganisere beite- og områdebruken og dermed ivareta fleksibilitet og resiliens. Hun omtaler det i forhold til endringer i arealbruk. og sier bl.a.: «reineierne fokuserer [...] mulighetene for å bruke området uten å miste nødvendig fleksibilitet og resiliens for å kunne manøvrere i forhold til stadig skiftende forhold» (vår oversettelse).

De virkelig store problemene oppstår når fleksibiliteten blir utilstrekkelig og ikke lenger gir rom for videre omorganisering. Som nevnt foran er da resiliensen lav og sårbarheten høy. Da er man sannsynligvis ikke langt fra et vippepunkt - et punkt hvor en liten forstyrrelse kan føre til store kvalitative, og også irreversible, endringer (Lenton, 2013, s. 2). ${ }^{21}$ Dersom inngrep tvinger samiske reindriftsutøvere ut av næringa, kan inngrepet være i strid med folkeretten (Norges Høyesterett, 2021; OED, 2016; Ravna, 2019). For begge distriktene ser vi eksempler på at selv om store inngrep over lang tid tilsynelatende ikke har så store effekter, kan nye tiltak/inngrep raskt gi store utslag. Vindturbiner får høsttrekket i Gielas til å stoppe opp, og distriktet får problemer med å gjennomføre årssyklusen sin. I Ildgruben ser vi både at manglende fjerning av gammel vei og preparering av en skiløype også kan medføre betydelige problemer.

Utfordringene for de to undersøkte reinbeitedistriktene er ikke særtilfeller. En inngrepsanalyse som er et grunnlagsdokument for den regionale planen for reindrift i Troms, påviser at reindrifta er utsatt for sammensatte og omfattende inngrep og forstyrrelser i forskjellige typer landskap. Dette gjelder mange typer inngrep, og ofte de typene som vi

21 Betingelsen for at et system skal nå et vippepunkt er at feedbackeffekten (tilbakekoplingseffekten) internt i systemet er større enn den opprinnelige forstyrrelsen 
har gjennomgått her. I tillegg kommer både problemer med rovdyr og klimaendringer. Flere større distrikter vurderes å være i eller nær en tålegrensesituasjon (Riseth \& Johansen, 2019).

Norske Reindriftsamers Landsforbund (NRL) har adressert problemer med samlet belastning over lang tid, og til dels nådd fram. Konsekvensutredningsforskriften krever at det legges vekt på samlede effekter, og at reinbeitedistrikter ses under ett (Forskrift om konsekvensutredninger, 2017), nå også bekreftet av Høyesterett (Norges Høyesterett, 2021). I en spørreundersøkelse svarer imidlertid de fleste distriktslederne at effektene av tidligere inngrep blir for lite tatt hensyn til (Riseth \& Winge, 2015). Dette resultatet bekreftes også av forespørsler fra Landbruks- og matdepartementet (LMD) til de aktuelle statsforvalterembetene (Riseth, 2020; Riseth \& Nygaard, 2018).

\section{Oppsummering og utfordringer}

Gjennomgangen av de to distriktene påviser at inngreps- og forstyrrelsesnivået er foruroligende høyt, og at det er åpenbare behov for å redusere belastningene som reindrifta utsettes for. Som det framgår, er dagens situasjon i stor grad resultatet av at tekniske framskritt over flere tiår som har åpnet nye muligheter for storsamfunnet. Medaljens bakside er tap av natur og habitater for mange arter (IPBES, 2019), men også nødvendig reindriftsareal (Hansen et al., 2018). Begge casene viser at en serie av påfølgende tekniske inngrep har lagt grunnlaget for at rekreasjonssamfunnet i løpet av noen tiår langt på vei er blitt dominant bruker av store reindriftsarealer.

Sannsynligvis vet hverken folk eller politikere flest hvor alvorlig dette er for reindrifta. Generelt er langsom og gradvis utvikling vanskelig å legge merke til. Manns minne strekker seg ikke så langt tilbake i tid, og de endringene vi diskuterer omfatter inntil to og tre generasjoner. Internasjonalt er dette kjent som shifting baseline syndrome (Soga \& Gaston, 2018). Når det i tillegg rammer en fåtallig minoritet og ei utkantnæring de fleste i Norge har lite kunnskap om og mangler relasjoner til, er det krevende å etablere institusjoner som kan bidra til å motvirke slike effekter. 
De ulike inngrepene er resultater av beslutninger fattet på ulike skalanivå, alt fra internasjonalt og mellomstatlig og helt ned til lokale saker på kommunalt og personlig nivå. Vi vil imidlertid anføre at nøkkelen til handling ligger i dynamikken mellom sentrale og lokale myndigheter. I regjeringsdokumentet Nasjonale forventninger til regional og kommunal planlegging 2019-2023 sies det bl.a. at «Ved endringer i arealbruk, er det viktig at reindriftas interesser veies opp mot andre samfunnsinteresser og at man søker å komme fram til løsninger som begrenser varig reduksjon av arealer og økte forstyrrelser for reindrifta» (KMD, 2019, s. 18). I en forskningsmessig evaluering av plan- og bygningslovens plandel oppsummeres som et av hovedfunnene at pbl $\$ 3-1 \mathrm{c}$ synes lite kjent i de fleste kommunene i paragrafens virkeområde, og at hovedbildet er at det kommunale selvstyret sørger for at samiske hensyn trumfes av ulike flertallsinteresser. Til tross for bedre regelverk sitter det nok langt inne for lokalpolitikere å anerkjenne at urfolkshensyn skal kunne gis forrang for det et lokalt flertall ønsker å prioritere (Hansen et al., 2018).

Det er nok grunnlag for å hevde at reindrifta over det meste av landet i praksis ikke oppnår tilstrekkelig forståelse og støtte; hverken fra allmennheten eller lokale og sentrale myndigheter til at lovverket kan fungere i samsvar med intensjonene. En fersk høyesterettsdom om to vindkraftverk på Fosen (Norges Høyesterett, 2021) illustrerer dette, se tekstboks 2.

\section{Tekstboks 2}

Saken gjelder to vindkraftverk på Fosen med i alt 151 vindturbiner. Sammen med andre vindkraftprosjekter utgjør de Europas største vindkraftverk på land. NVE vedtok konsesjonene og ekspropriasjon av grunn og rettigheter i 2010. Reindrifta gjorde gjeldende at utbyggingen krenker deres rettigheter til kulturutøvelse, men fikk ikke medhold i OEDs klagevedtak fra 2013. Saken ble så brakt inn for domstolene. Fosen Vind DA fikk likevel tillatelse fra OED til å starte byggingen, og vindkraftverkene sto ferdig i henholdsvis 2019 og 2020. Saken er behandlet av både tingrett og lagmannsrett. 
Høyesterett kjente 11. oktober 2021 konsesjonene for to vindkraftverkene på Fosen ugyldige fordi utbyggingen krenker reindriftssamenes rett til kulturutøvelse. Domstolen bygger på at ut fra FNs konvensjon om sivile og politiske rettigheter (SP), artikkel 27, er samisk reindrift en form for vernet kulturutøvelse (vår kursivering). Det foreligger en krenkelse av rettighetene etter SP artikkel 27 fordi inngrepet fører til vesentlige negative konsekvenser for muligheten til kulturutøvelse. Inngrepet må også ses i sammenheng med andre tiltak, både tidligere og planlagte. Den samlede effekten av tiltakene er avgjørende for om det foreligger krenkelse.

Denne dommen gir grunn til mange refleksjoner, både om hvordan dette kunne skje, og om konsekvensene (Fjeldavli, 2021). Vi vil spesielt fremheve at saken illustrerer at sentralmyndighetene til tross for protester, også fra FNs komité for eliminering av rasediskriminering (Sámiráđđi, 2018), har misbrukt sin makt til å ignorere alle argumenter fra samisk side og til og med lot Regjeringsadvokaten gå inn som partshjelp for utbygger. Her har samenes tilsvarende erfaringer med andre urfolk (Riseth, 2021d). Den påtroppende regjeringa har mildt sagt mange muligheter til forbedring. Generelt er det behov for administrative ordninger som bidrar til å sørge for at samlede effekter av inngrep og forstyrrelser virkelig vektlegges og stopper nye inngrep. Kort sagt er det behov for en grunnleggende anerkjennelse av at reindrifta i gitte tilfelle må være premissleverandør for hva som kan skje hvor og når i utmarka, og en vilje til å se inngrep og forstyrrelser i en større sammenheng. Vi vil antyde en serie tiltak som bedre kan inkludere reindriftas kunnskap i kommunale plan- og utbyggingsprosesser:

- Reindriftas distriktsplaner kan utnyttes bedre (Reindriftsloven, 2007, \$62)

- Det kan utvikles bedre og mer oppdaterte reindriftskart.

- Kommunene kan pålegges å føre arealregnskap for tapt reindriftsareal.

- Det kan stilles større krav til konsekvensutredninger (KU), både med hensyn til innhold og slik at reindrifta får godkjenningsrett for utredere. 
- NRL har i flere år etterlyst statlige planretningslinjer for planer som angår reindrift.

- Interkommunale ${ }^{22}$ og regionale planer bør også stimuleres.

- Ikke minst er det behov for både politikeropplæring og generell folkeopplysning om samiske forhold, særlig i skoleverket.

Særlig det siste punktet bør sees i forhold til behovet for et sluttoppgjør med den historiske fornorskingspolitikken og en nasjonal forsoning (Sannhets- og forsoningskommisjonen, 2020). Med henvisning til Nasjonale forventninger (KMD, 2019) vil vi peke på det åpenbare misforholdet mellom offisielle målsettinger og den faktiske situasjoner reindrifta står i. Det vil være meget krevende å snu dette til en reell offensiv for å bevare reindriftslandet, og det vil kreve bred og koordinert offentlig innsats. Statlige planretningslinjer og regionale reindriftsplaner har en naturlig plass her.

På tampen skal vi nevne ei ny lovendring som skal styrke reindriftas posisjon. Stortinget vedtok 3. juni 2021 endringer i sameloven. ${ }^{23}$ Kommuner og fylkeskommuner har nå plikt til å «konsultere representanter for berørte samiske interesser i saker om lokale forskrifter og andre beslutninger eller tiltak som vil kunne påvirke samiske interesser direkte» (Sameloven, 2021, $\$ 4-4$ ). I praksis betyr at det at bl.a. reinbeitedistrikter, skal involveres tidlig i beslutningsprosessen i saker som angår dem. Det vil innbefatte planer og utbyggingsprosjekter.

\section{Referanser}

Danell, Ö. (2010). Renskötseln och rovdjuren. Rangifer report, 14, 78-79.

Danielsen, I. E. \& Riseth, J. Å. (2010). Sikring av en boerekraftig reindrift $i$

Trollheimen. Gjennomgang og vurdering av den driftsmessige situasjonen.

Utredningsoppdrag for Landbruks- og Matdepartementet (Norut rapport 11/2010).

Norut Tromsø. https://hdl.handle.net/11250/2727746

\footnotetext{
22 Typisk vil hver av kommunene behandle sine planer uten sideblikk til inngrep som rammer reindrifta i andre kommuner. Det tilsier behovet for interkommunale eller regionale planer. 
Fjeldavli, C. (2021, 13. oktober). Når rives Fosen-turbinene? [Leserinnlegg]. Klassekampen, s. 20.

Fjellheim, E. M. (2020, 5. februar). Ærede Lagmannsrett. Harvest. https://www. harvestmagazine.no/pan/aerede-lagmannsrett

Fjellheim, S. (2012). Gåebrien sijte - en sameby i Rørostraktene. Røros.

Forskrift om konsekvensutredninger. (2017). Forskrift om konsekvensutredninger (FOR-2017-06-21-854). Lovdata. https://lovdata.no/forskrift/2017-06-21-854

Forskrift for Reindriftas Utviklingsfond. (2019). Forskrift for Reindriftas Utviklingsfond (FOR-2019-06-20-864). Lovdata. https://lovdata.no/forskrift/ 2019-06-20-864

Gunderson, L. H. \& Holling, C. S. (2002). Panarchy. Understanding transformations in human and natural systems. Island Press.

Gunn, A. (2016). Rangifer tarandus. The IUCN red list of threatened species 2016. International Union for Conservation of Nature. https://dx.doi.org/10.2305/ IUCN.UK.2016-1.RLTS.T29742A22167140.en

Hansen, F. (2021, 24. september). Støtter aksjonistene - sier nei til vindturbiner. Fremover. https://www.fremover.no/stotter-aksjonistene-sier-nei-tilvindturbiner/s/5-17-900072

Hanssen, G. S., Aarsæther, N., Hofstad, H., Anker, H. T., Kalbro, T., Buanes, A., Børrud, E., Grønning, M., Holth, F., Higdem, U., Kvalvik, K. J., Nordahl, B. I., Nyseth, T., Ringholm, T., Riseth, J. Å., Strand, A. \& Winge, N. K. (2018). En operativ lov? Spenningen mellom lovens intensjoner og planpraksis - behov for forbedring? I G. S. Hanssen \& N. Aarsæther (Red.), Plan- og bygningsloven 2008: En lov for vår tid? (s. 481-521). Universitetsforlaget.

Holling, C. S. (1973). Resilience and stability of ecological systems. Annual Review of Ecology and Systematics, 4, 1-23. https://doi.org/10.1146/annurev. es.04.110173.000245

Ildgruben. (2017). Distriktsplan Ildgruben reinbeitedistrikt. Tverrvatnet oktober 2017. Internasjonal konvensjon om sivile og politiske rettigheter. (1966). Internasjonal konvensjon om sivile og politiske rettigheter. Lovdata. https://lovdata.no/lov/199905-21-30

IPBES. (2019). Global assessment report on biodiversity and ecosystem services (Rapport). The Intergovernmental Science-Policy Platform on Biodiversity and Ecosystem Services. https://www.ipbes.net/global-assessment

Kjørstad, M., Bøthun, S. W., Gundersen, V., Holand, Ø., Madslien, K., Mysterud, A., Myren, I. N., Punsvik, T., Røed, K. H., Strand, O., Tveraa, T., Tømmervik, H., Ytrehus, B. \& Veiberg, V. (Red.). (2017). Miljøkvalitetsnorm for villrein. Forslag fra en ekspertgruppe (NINA rapport 1400). Norsk institutt for naturforskning. http:// hdl.handle.net/11250/2471598 
Kommunal- og moderniseringsdepartementet. (2019). Nasjonale forventninger til regional og kommunal planlegging 2019-2023. https://www.regjeringen. no/no/dokumenter/nasjonale-forventninger-til-regional-og-kommunalplanlegging-20192023/id264509o/

Kurtén, B. (1969). Istiden. International Book Production.

Labba, E. A. (2020). Herrarna satte oss hit: Om tvångsförflyttningarna i Sverige. Nordstedts.

Landbruksdirektoratet. (2019). Totalregnskap for reindriftsnoeringen. Regnskap 2018 og budsjett 2019. (Rapport nr. 31/2019). Landbruksdirektoratet.

Landbruksdirektoratet. (2015-2020). Ressursregnskap for reindriftsnoringen. Landbruksdirektoratet.

Larsen, R. K., Raitio, K., Sandström, P., Skarin, A., Stinnerbom, M., Wik-Karlsson, J., Sandström, S., Österlin, C. \& Buhot, Y. (2016). Kumulativa effekter av exploateringar på renskötseln. Vad behöver göras inom tillståndsprocesser? (VINDVAL rapport 6722). Naturvårdsverket. http://www.naturvardsverket.se/ Documents/publikationer640o/978-91-620-6722-9.pdf?pid=19076

Lenton, T. M. (2013). Environmental tipping points. Annual Review of Environment and Resources, 38, 1-29. https://doi.org/10.1146/annurev-environ-102511-084654

Löf, A. (2014). Challenging adaptability. Analysing the governance in reindeer husbandry in Sweden [Doktoravhandling, Umeå Universitet]. DiVA. http://urn. kb.se/resolve?urn=urn:nbn:se:umu:diva- 87976

Miljødirektoratet. (u.å.). Tilstandsrapport for naturen på jorda [Faktaark om IPBES]. Miljødirektoratet \& NINA. https://www.miljodirektoratet.no/globalassets/bilder/ nyhetsdokumenter-old/nyheter-vedlegg/faktaark-versjon-10.pdf

Nilsen, E. B. \& Strand, O. (2017). Populasjonsdynamiske utfordringer knyttet til fragmentering av villreinfjellet (NINA Temahefte 70 ). Norsk institutt for naturforskning. http://hdl.handle.net/11250/2430979

Nilsson, R., Lauritz, L. \& Blom, A. (2015). Kumulativa konsekvenser för rennäringen (Protect Sapmi). LKAB Gabna och Laeveas samebyar. https://www.lkab.com/sv/ SysSiteAssets/documents/blandat/metodhandbok_kumulativa-konsekvenser-forrennaringen.pdf

Norges Høyesterett. (2021). Høyesteretts dom 11. oktober 2021, HR-2021-1975-S (sak nr. 20-143891SIV-HRET, sak nr. 20-143892-SIV-HRET og sak nr. 20-143893SIVHRET). https://www.domstol.no/enkelt-domstol/hoyesterett/avgjorelser/2021/ hoyesterett-sivil/hr-2021-1975-s/

Nybakken, V. Ø. (2021, 26. september). Markerte motstand til vindkraft - og rettet oppmerksomheten mot samiske interessert. Fremover. https://www.fremover. no/markerte-motstand-til-vindkraft-og-rettet-oppmerksomheten-mot-samiskeinteresser/s/5-17-900491 
Næsje, T. (2019, 25. oktober). Nye Narvik kommune: Krever at det åpnes for mer vindkraft. Fremover. https://www.fremover.no/nye-narvik-kommune-krever-atdet-apnes-for-mer-vindkraft/s/5-17-611587

Næsje, T. (2021, 4. oktober). Nei til vindturbiner i Narvik. Fremover. https://www. fremover.no/nei-til-vindturbiner-i-narvik/s/5-17-903561

Olje- og energidepartementet. (2016). Fred. Olsen Renewables AS - Kalvvatnan vindkraftverk i Bindal og Namsskogan kommuner - klagesak. Ref. o8/3602 [Brev av 11.11.2016]. https://www.regjeringen.no/contentassets/ 2cb371d9a0204b19a8a914ae830a62ee/vedtak-kalvvatnan.pdf

Pedersen, S. (2015). Samenes historie: Fra undertrykking til kulturelt likeverd. I A. Holt-Jensen \& A. Dyrvik. Likeverd. Grunnlaget for demokrati (s. 173-192). Res Publica.

Plan- og bygningsloven. (2008). Lov om planlegging og byggesaksbehandling (LOV2008-06-27-71). Lovdata. https://lovdata.no/lov/2008-06-27-71

Rasch, C. A. (2017). Samlet belastning og Reindrift - En studie av effekter av utbygging i Ildgruben reinbeitedistrikt [Masteroppgave, Norges miljø- og biovitenskapelige universitet]. Unit. http://hdl.handle.net/11250/2468079

Ravna, Ø. (2010). Lappekodisillen av 1751 og dens rettslige betydning i dag. Lov og rett, 49(7), 392-406.

Ravna, Ø. (2019). Same- og reindriftsrett. Gyldendal.

Reindriftsforvaltningen. (1995-2014). Ressursregnskap for reindriftsnoeringen.

Reindriftsloven. (2007). Lov om reindrift (LOV-2007-06-15-40). Lovdata. https:// lovdata.no/lov/2007-06-15-40

Riseth, J. Å. (2020). Hvilken status har reindriftssamisk kunnskap? Hvordan kan samfunnet anvende den bedre? I B. Fossum (Red.), Åarjel-saemieh. Samer i sør (Årbok nr. 13, s. 95-109). Saemien Sijte,

Riseth, J. Å. (2021a, 1. februar). Vindkraftanlegg, rein og urfolk - et varsku til Narvik kommune [Leserinnlegg]. Fremover. https://www.fremover.no/vindkraftanleggrein-og-urfolk-et-varsku-til-narvik-kommune/o/5-17-814920

Riseth, J. Å. (2021b, 9. februar). Vindturbiner og «ulv, ulv»-rop? [Leserinnlegg]. Fremover. https://www.fremover.no/vindturbiner-og-ulv-ulv-rop/o/5-17-817767

Riseth, J. Å. (2021C, 19. februar). Hvilken virkelighet? Reindrift og kraftanlegg [Leserinnlegg]. Fremover. https://www.fremover.no/hvilken-virkelighet-reindriftog-kraftanlegg/o/5-17-821245

Riseth, J. Å. (2021d). Disappearing flexibility. The story of Gielas reindeer herding district. I R. Sørly, T. Ghaye \& B. Kårtveit (Red.), Stories of change and sustainability in the Arctic regions: The interdependence of local and global (Kap. 2). Routledge. https://doi.org/10.4324/9781003118633

Riseth, J. Å., Danielsen, I. E. \& Johansen, B. (2016). Trasévalg for framtidig E6 over Kvoenangsfjellet. Konsekvensanalyse for reindrift (Norut rapport 18/2016). https:// www.nyeveier.no/media/m14c4qte/vo9-konsekvensutredning-reindrift.pdf 
Riseth, J. Å. \& Johansen, B. (2019). Inngrepsanalyse for reindrifta $i$ Troms (Norut rapport 23/2018). https://www.tffk.no/_f/p1/ib5af7653-5341-4032-bco7o78f719dc5e5/inngrepsanalyse.pdf

Riseth, J. Å. \& Nygaard, V. (2018). Samiske hensyn i planleggingen. I G. S. Hanssen \& N. Aarsæther (Red.), Plan-og bygningsloven 2008: En lov for vår tid? (s. 307-324). Universitetsforlaget.

Riseth, J. Å. \& Tømmervik, H. (2017). Klimautfordringer og arealforvaltning for reindrifta i Norge. Kunnskapsstatus og forslag til tiltak - eksempler fra Troms (Norut rapport 6/2017). https://norceresearch.brage.unit.no/ norceresearch-xmlui/bitstream/handle/11250/2659191/Norut_rapport_6-2017. pdf? sequence $=1$ \&isAllowed $=y$

Riseth, J. Å. \& Winge, N. K. (2015). Reindrift, arealinngrep og utbygging: Blir reindrifta hørt i utbyggingssaker? Reindriftsnytt, 2, 4-5.

Risvoll, C., Pavall, M., Lifjell, T., Eilertsen, S. M., Lundberg, A. K. \& Veland, S. (2019). Synliggjøring av flaskehalser - et steg i retning av mer representative kart. Reindriftsnytt, 2, 10-16.

Risvoll, C., Haavelsrud, G. \& Riseth, J. Å. (under utgivelse). Falling between the cracks of the governing systems: Present realities of risk and uncertainty in pastoralism in northern Norway. Under utarbeidelse til spesialnummer av Weather, Climate and Society.

Røed, K. (2014). Genetisk variasjon hos rein som indikator for opprinnelse og innvandringshistorie. Norsk veterinortidsskrift, 126(2), 72-78.

Rørholt, A. C. (2009). Encroachments as a problem for Sami reindeer husbandry [Masteroppgave, Universitetet i Tromsø]. UiT Munin. https://hdl.handle. net/10037/2078

Sameloven. (2021). Lov om Sametinget og andre samiske rettforhold (LOV-2021-0611-76). Lovdata. https://lovdata.no/lov/1987-06-12-56

Sámiráđđi. (2018, 28. desember). Confound by Norway's disrespect of CERD's request in the Fosen case. https://www.saamicouncil.net/news-archive/confoundby-norways-disrespect-of-cerds-request-in-the-fosen-case

Sannhets- og forsoningskommisjonen. (u.å.). Mandat. https://uit.no/kommisjonen/ mandat

Sannhets- og forsoningskommisjonen (Norge). (2020, 7. september). I Wikipedia. https://no.wikipedia.org/wiki/Sannhets-_og_forsoningskommisjonen_(Norge)

Selznick, P. (1951). Institutional vulnerability in mass society. American Journal of Sociology, 56(4), 320-331. https://doi.org/10.1086/220756

Skarin, A. \& Åhman, B. (2014). Do human activity and infrastructure disturb domesticated reindeer? The need for the reindeer's perspective. Polar Biology, 37, 1041-1054. https://doi.org/10.1007/soo30o-014-1499-5 
Sluttprotokoll fra reindriftsavtaleforhandlingene. (2019). Landbruks- og matdepartementet \& Norske Reindriftsamers Landsforbund. https://www. regjeringen.no/contentassets/a33c2d5804524d75886bbbo6f985f16e/protokoll.pdf Soga, M. \& Gaston, K. J. (2018). Shifting baseline syndrome: Causes, consequences, and implications. Frontiers in Ecology and the Environment, 16(4), 222-230. https://doi.org/10.1002/fee.1794

Svonni, L. (1983). Fjällrenskötselns årscykel sett ur en helhetsbedömning av markebehovet og hur ulika orsakskedjor styr detta behov (Vedlegg 1 i SOU 1983: 67, Rennäringens ekonomi. Betänkande av rennäringskomittén, s. 251-266).

Tsunokawa, K. \& Hoban, C. (1997). Roads and the environment (World Bank technical paper nr. 376). World Bank. https://doi.org/10.1596/o-8213-4031-X

Vistnes, I., Nellemann, C. \& Bull, K. S. (2004). Inngrep i reinbeiteland. Biologi, jus og strategier i utbyggingssaker (NINA temahefte 26). Norsk institutt for naturforskning. https://www.nina.no/archive/nina/PppBasePdf/temahefte/ $26 \% 20 . p d f$

Watson, R. T., Zinyowera, M. C. \& Moss, R. H. (Red.). (1996). Book climate change 1995. Impacts, adaptations and mitigation of climate change: Scientific-technical analyses. Cambridge University Press. 


\title{
Mot ei framtid for utmarksbeite - om beiting, sjølvkjensle og forståing mellom folk
}

\author{
Bjørn Egil Flø
}

Norsk institutt for bioøkonomi (NIBIO)

\begin{abstract}
The once-proud graziers have begun to have doubts. They have begun to doubt whether everything they used to believe, everything that gave meaning to what they have been doing, still makes sense.

This essay takes the reader home to the graziers and out into the Norwegian countryside: the mountains, forests and deep fertile valleys, the terrain the Norwegians call outfields (utmark). Based on conversations with graziers in different parts of Norway, this essay discusses the future of grazing in the outfields against the backdrop of the big, as well as the small, political and social issues that both the graziers and we as a society are facing.

For the graziers are struggling with many questions today. Is it no longer ecologically sustainable to use the outfields resources for food production? Shouldn't the outfields be a resource for the production of food and fibre anymore? Is there no place for grazing animals in the Norwegian mountains in the future? Grazing farmers are currently asking themselves these questions and more. They feel degraded and exposed in the public debate, and the feeling tears at their self-image and makes every day grey; it becomes increasingly difficult to find motivation for each day that passes.

But what can be done to reverse this trend? What can the grazing farmers do themselves, and what do we others need to do for them, politically as well as socially? This chapter discusses the emergence of a new concept of outfields and how it has affected grazing in the outfields. The essay raises a number of important questions that we as a society need to address in the debate about the future role of traditional upland grazing areas in our landscape.
\end{abstract}

Keywords: sheep farming, grazing, outfields, commodification, middle class, elite

Sitering: Flø, B. E. (2021). Mot ei framtid for utmarksbeite - om beiting, sjølvkjensle og forståing mellom folk. I F. Flemsæter \& B. E. Flø (Red.), Utmark i endring (Kap. 3, s. 67-92). Cappelen Damm Akademisk. https://doi.org/10.23865/noasp.151.ch3

Lisens: CC BY-NC-ND 4.0 
Vestlandsvêret set vindaugsviskarane på prøve, men likevel er det lett å sjå at mange av gardane langs vegen har lege brakk ei tid. Små bruk som ikkje lenger evna å gi nok kapital til å rettferdiggjere framleis drift, er no nedlagde. Men det ser ut som dei fleste markene er i bra stand, så jorda vert nok driven her. Nett det gjeld dessverre ikkje overalt lenger, særleg ikkje på Vestlandet.

Eg er på veg innover til ei lita fjordbygd. Der skal eg møte med seks bønder i eit sauebeitelag. Eg møtte den eine av dei i fjellet nokre månader før, han var og såg etter sau og kom over meg då eg sat og rasta ved ei lita elvesikle som kryssa stien eg gjekk etter.

- Me har eit godt produsentmiljø her, sjølv om me har blitt forre med åra, så er det likevel eit godt miljø ... både aktive eldre bønder og ikkje minst fleire unge som ser ut til å ville satse, fortalde han meg.

Det er ikkje uvanleg at bønder snakkar om produsentmiljøet når eg spør om korleis det er med landbruket på staden. Me veit at eit godt produsentmiljø er viktig for at bøndene skal ha drivkraft nok til å halde fram (Flaten, 2017). Einsemda kan bli tung å bere i landbruket (Bjørkhaug, 200o). Det er lenge sidan det sokalla familiebruket var eit bruk der familiemedlemmane arbeidde saman på markene. Den draumen kvarv gradvis frå sist på 70-talet og framover på 8o-talet, her heime likesom i heile vestverda. Draumen var, som Almås (2002) skriv, på ingen måte særnorsk. «Han vart [også] drøymd på Jyllands heder, mellom åsane i Bayern og på den amerikanske prorien» (s. 243). Familiebruket var sjølve grunnsteinen i det landbrukspolitiske byggverket i etterkrigstida, det skulle sikre sosial fred og økonomisk vekst i dei vestlege industrilanda (Friedmann, 1982). Men familiebruket i draumen var noko anna enn det me såg i røyndomen. For i røynda er det i beste fall eit bruk der ein person går aleine i kvardagen. Aleine står bonden i stigane, aleine sit ho på traktoren og aleine går ho i fjøset. I denne kvardagen vert det om mogleg viktigare enn nokon gong før å ha fagfellar i nærleiken som ein kan drøfte det praktiske så vel som det upraktiske med. 


\section{Den nye uroa}

- Det er då grunn for å starte undre seg. Den unge bonden som kom litt seinare enn dei andre til møtet, hadde så vidt sett seg før han braut inn $\mathrm{i}$ samtala. Det verka som han hadde tenkt at dette var noko han berre måtte få seie, som om det var dette som var hans viktigaste bodskap. Enda me snakka om kvaliteten på beitet deira og om kor mange sau og lam dei kunne sleppe i beiteområdet, så pensa han oss lett inn på eit anna spor.

- I heile mitt liv har eg trudd på det eg har heldt på med. Eg har trudd at det å sleppe sau i utmarka har vore bra for alt.

Dei andre nikka seg samd med han, det verka som dei forstod kva han snakka om. Men sjølv var eg ikkje heilt med.

- Men no er me stempla som klimaverstingar, medan dei som stenger inne gris og kylling som ligg på seg betente svisår i store fjøs, vert hylla som miljøvenlege heidersmenn. Det er som om alt har blitt snudd opp ned.

Ja, eg greidde å kople meg på no. Drøvtyggarar, dei med det raude kjøtet, er også dei som slepp ut den potente klimagassen metan der dei ligg og jortar i ettermiddagssola. Det har dei rekna seg fram til no, dei som reknar på utslepp av klimagassar frå landbruket. Og sjølv om det er usemje mellom forskarane om reknemetoden, er det likevel desse reknestykka som er grunnlaget for klimaråda til politikarane så vel som til forbrukarane; et helst det kvite kjøtet, om du i det heile skal ete kjøt då.

- Det er klart at dette toerer på motivasjonen, eg er sant å seie ikkje sikker på om eg orkar så mykje lenger.

Så no sit han her, den unge vestlandsbonden som så langt i livet har tenkt at det han gjer, er bra for miljøet så vel som for samfunnet, og fortel at den nye klimadebatten tærer på motivasjonen. Heile røyndomsbiletet som han har tufta meiningsinnhaldet for si eiga drift på, er i ferd med å rase saman. Han har gått frå å vere ein stolt produsent av framifrå lammekjøt til å bli ein klimaversting i løpet av berre kort tid. 
- Er dette ei uro dokke deler? Spør eg dei andre, men eg kjenner at eg veit svaret. For når eg ser på dei fem andre bøndene kring bordet, kan eg sjå semja i andletet åt dei alle. Jau då, dei deler absolutt denne nye uroa.

Den nye uroa legg seg som ei ny utfordring oppå fleire lag med gamle og meir velkjende utfordringar. Den legg seg oppå den jamt dårlegare økonomien, økonomien som på mange måtar har skapt bondeeinsemda og kravt at bøndene lyt vekse i storleik for kvart einaste år. Den legg seg oppå dei sosialt belastande usemjene med grannar som ikkje held utgarden sin ved like, den legg seg oppå ulempene som følgjer med turgåarar som ikkje let att grindene etter seg. Den legg seg oppå alle lausbikkjene åt eigarar som ikkje forstår at kjæledyret deira eigentleg er eit rovdyr, og alle bilane som parkerer slik at det er vanskeleg å kome forbi med krøter utan at ei kyr bryt sund ein sladrespegel. Men viktigast er det at det også legg seg oppå eit jamt meir einsamt strev i ei næring med svekka sosial og politisk posisjon lokalt så vel som nasjonalt.

\section{Samtalane - metode og material}

Dei seks vestlandske beitebrukarane som denne kvelden sat samla kring eit bord, ei kanne kaffi og ei skål søte kjeks innkjøpt på det lokale samyrkelaget, var den eine av til saman fire grupper av beitebrukarar, eller meir presist beitelag, som eg har snakka med i tilknyting til forskingsprosjektet «Mot ei framtid for utmarksbeite». ${ }^{1}$

Tanken var at utfordringane som beitebrukarane står overfor kring om i landet, skil seg frå region til region, dei skil seg frå kvarandre i høve til kva eigedoms- eller bruksrettsforhold dei har til beiteområdet, og dei skil seg frå kvarandre i høve til kor mykje trykk dei opplever frå andre typar utmarksbruk som til dømes rekreasjon, reiselivs-, gruve- eller kraftindustri. Og ikkje minst skil dei seg frå kvarandre i høve til relasjonane mellom beitebrukarane sjølve så vel som relasjonane mellom beitebrukarane og andre lokale utmarksbrukarar. Relasjonar som fort kan vere definert av gamle saker som knapt ingen lenger hugsar opphavet til, så

1 Prosjektet med den engelske tittelen «Towards a future for common grazing», og kortnamnet FUTGRAZE, er finansiert av Forskningsmidlene for jordbruk og matindustri (matfondet). 
vel som nye og konkrete saker som følgjer i kjølvatnet av dei generelle utviklingstrekka både innan næringa og i samfunnet elles.

Derfor valde prosjektet å studere beitelag i ulike delar av landet. Regionane eg har vore i, kan summerast opp som Vest-, Aust-, Nord- og Midt-Noreg. Der har eg reist til grender og bygdesamfunn og invitert medlemmar av det lokale beitelaget til ein samtale om korleis dei driv, og kva utfordringar dei står overfor, og ikkje minst kva tiltak dei gjer for å freiste å møte utfordringane på best mogleg måte. I kvart av lokalsamfunna har eg innleia studien med eit lengre gruppeintervju med eit utval på mellom 6 og 8 medlemmar i det lokale beitelaget. I kvart av studieområda har eg bedd leiaren av beitelaget om å invitere med seg eit utval av andre medlemmar i laget som hadde tid og høve til å stille til gruppesamtalen. I tillegg til desse gruppesamtalane har eg også følgt opp med nokre individuelle intervju, ofte basert på ei interesse for å få litt meir detaljar om saker og ting som vart nemnt i gruppesamtalane. Det kan vere for å følgje opp personlege saker som ikkje eigna seg for ein gruppesamtale, eller saker som involverer andre enn dei som var til stades under gruppesamtalen. I tillegg til intervjua og samtalane med beitebrukarane har eg også følgt spora i forteljingane deira og snakka med personar involvert i saker som beitebrukarane tok opp, ikkje for å faktasjekke forteljingane deira, men for å også få den andre versjonen. For me er slik laga me menneske at me opplever ulikt, og i mi verd er ei oppleving like gyldig som ei anna.

Totalt er det gjennomført fire gruppesamtalar på om lag 3 timar for kvart intervju, med like mange beitelag. Det er gjort 23 individuelle djupneintervju av ulik lengde, ni av desse var beitebrukarar anten knytt til dei beitelaga eg hadde gruppesamtalar med, eller knytt til tilgrensande beitelag. I tillegg har eg gjort 14 intervju med grunneigarar eller andre utmarksbrukarar i dei ulike områda. Samstundes har eg også snakka med folk som eg berre har møtt på ute i grendene. Det er samtalar gjort utan nokon intervjuguide slik som for dei meir formelle intervjua, men berre vanlege samtalar med folk eg har møtt på i fjellet eller langs vegane gjennom bygdene. Ofte har eg ikkje kjent bakgrunnen deira eller den tilknytinga dei har til fjellet eller bygda på førehand, anna enn eg har lytta til det dei har fortalt meg. Forteljingane deira har lagt seg til alle dei andre 
forteljingane og vore med på å danne det biletet eg etter kvart har sett vekse fram frå dette arbeidet.

I dette essayet vil eg nytte denne eine vestlandske casen for å fortelje ei historie som like gjerne kunne vore fortalt ut frå kvar av dei tre andre casane i studien. Rett nok ville dei konkrete historiene vorte annleis, men det generelle fenomenet ville vore det same og utfallet av analysen sameleis.

Så nett no set eg altså på ein sjukeheimskafé i ein liten tettstad ein dryg times køyretur frå ein vestlandsby. Her er beitelaget representert med seks av dei til saman 16 medlemmane i laget. Alle har dei sett av kvelden til dette møtet med ein forskar dei ikkje kjenner, men som har sagt at han ville høyre korleis dei driv beitelaget og kva dei tenkjer om framtida for utmarksbeite.

\section{Utfordringane}

Mykje av det dei fortel, ber i seg tydelege likskapar med utfordringane eg også har høyrt frå andre beitelag kring om i landet. Mange av dei kan relaterast til endringane sjølve næringa har vore utsett for dei siste 40-50 åra. Dei kan relaterast til endringane knytt til moderniseringa og spesialiseringa av landbruket.

For det har skjedd noko med beitenæringane våre dei siste 40-50 åra. Frå ei tid då mesta alle i grendene hadde husdyr på beite - ikkje nødvendigvis mange, men nok til at dei deltok i felles arbeid med utgardar og anna, og ikkje minst nok til å forstå kva det innebar å ha dyr i utmarka så er det no stadig lengre mellom både husdyrbrukarane og ikkje minst mellom dei som slepp husdyr på utmarksbeite. For i kjølvatnet av opptrappingsvedtaket på 1970-talet endra norsk landbruk seg. Optimismen auka, bøndene bygde nye føøs med lyse og lettstelte husdyrrom, og dei drenerte myrane og dyrka nytt jordbruksland som dei sådde til med timotei, raigras og anna som eigna seg godt til ensilering i dei nye tårnsiloane som trona så vakkert i tverrendane åt dei nye fjøsa. Og med alle desse endringane, med dei nye fjøsa og all den nye teknologien kom også dei nye ekspertråda. No skulle ikkje lenger mjølkekyr ut på beite om somrane, no skulle dei stå på bås heile året. Bøndene vart råda til å 
spesialisere seg, dei skulle satse på ein type produksjon. Dei skulle ikkje ha poteter, gulrot og kålrabi samstundes som dei også hadde mjølkekyr, sau og gris. Nei, dei skulle ha ein, eller i meste fall to produksjonar.

Trass vedtak om opptrapping, trass optimismen og trass investeringsiver og nydyrking, gjekk likevel talet på bruk ned. Bøndene åt kvarandre, vart det sagt. Grannar «kannibaliserte» på grannar, og slik vaks storleiken på bruka i takt med at talet på bruk minka. Framover på 70-, 80- og 90-talet endra grendene seg dramatisk. Det mangfaldige jordbrukslandskapet med ei blanding av åker, eng og beitemarker forsvann meir og meir av syne til fordel for einfaldet. Sjølv om den totale jordbruksproduksjonen auka ei tid, kom dei aktive bøndene i sterkt mindretal kring om i dei norske bygdene. Gradvis vart også utmarka mindre viktig for bøndene som var att.

Typisk for Vestlandet var det mjølkeproduksjon dei satsa på, dei satsingsvillige bøndene. Då la dei gjerne ned sauedrifta samstundes.

- Me hadde høge tapstal her samanlikna med innlandet, fortalde Arne. Han var leiaren av beitelaget og den som også snakka mest i denne gruppa.

- Me var ikkje plaga av rovdyr, men det var ein ikkje elles i landet heller den tida. Til gjengjeld har me mange flog og skar som dyra kan gå seg fast $i$, og ikkje minst har me mykje romegras.

Så alveld ${ }^{2}$ var tydelegvis eit problem.

- I tillegg vart nok også det å fortsatt skulle drive med sau sett på som litt lågare status, for det var mjølk som var ordentleg jordbruk her på Vestlandet, sau var for hobbybønder.

- Men viktigast var nok økonomien. For beita våre her heime var ikkje gode nok for sau lenger, slakta vart for små rett og slett.

Og det var på den tida at dei som framleis dreiv med sau i området her, fann seg eit ledig beite i fjella langt lenger inne i landet. Over 20 mil

2 Alveld er ein sjukdom hjå sau som gir leverskade, oppsvulma andlet og overfølsemd for lys. Ein har antatt at sjukdomen heng saman med inntak av romeplanta, men sopp eller algar er også ei moglegheit, kanskje i kombinasjon med rome. 
heimanfrå fann dei eit beite høgt til fjells, her var det fritt for både romegras og farlege flog, og i tillegg var det godt beite. Ja, svært godt, samanlikna med utmarksbeitet heime. Dei fortalde meg at nett det at dei fann dette beiteområdet, gjorde at fleire som elles ville ha slutta med sau, likevel valde å halde fram ei stund til.

- Alternativet for far ville vore rein mjølkeproduksjon, sa den unge bonden som nett hadde avslørt sitt klimamismot. Far hans var på ingen måte aleine om det, dei andre kunne stadfeste at utan eit ordentleg fjellbeite ville det vere vanskeleg å rettferdiggjere framleis sauedrift for bøndene her. Dermed vart det heimlege beitet liggande ubrukt, og sauen forsvann også ut av medvitet for lokalbefolkninga her.

- Sauen vart berre synleg for folk når han var på vårbeite på bøane og når me henta den heim frå fjella. Elles såg ikkje folk den her i bygda.

- Hadde det noko å seie då? spurde eg.

- Ja, det er då mykje sau i denne vesle bygda her, men det er vel ingen som vil kalle det ei sauebygd med mindre dei kjenner landbruket her nokså godt, sa Arne i eit forsøk på å forklare denne tungnæme forskaren korleis eit samfunn verkar.

Jau då, eg kan forstå kva han siktar til. Særleg etter å ha snakka med beitebrukarar frå andre delar av landet, veit eg kva som skjer når sauen forsvinn ut av medvitet åt bygdebefolkninga. Men det er ikkje nødvendigvis ein direkte samanheng med at bøndene leiger beite i andre fjell enn heimefjella, det skjer også der den går rett utom utgarden. Beitebrukarane i Nordland til dømes - der sauen beitar i fjella rett bak gardane - fortalde meg mykje den same forteljinga. Også der snakka ein om at beitebruken forsvann ut av medvitet åt resten av lokalbefolkninga. Sameleis snakka beitebrukarane i Trøndelag om at bygdefolk flest ikkje lenger er like «medvitne» beitebrukarane sine behov for at dei skal kunne halde fram beitebruken i utmarka. I innlandet har forholdet mellom rettshavarane i allmenningen skapt motsetningar mellom dei som enno beitar der og dei som ser skogen berre som skog og fjellet som ein arealressurs for hyttebygging eller anna reiselivsrelatert utvikling. For det som har slått meg 
tydelegast gjennom desse samtalane med beitebrukarar kring om i landet - ikkje berre på denne turen til denne vestlandsgrenda, men også i dei tre andre grendene som har vore med i dette arbeidet - er forteljinga om den aukande avstanden mellom beitebrukarane i bygdene og resten av bygdebefolkninga. Folk i bygdene har gradvis vorte meir fråkopla landbruket og då særleg beitebruken. Men lat oss kome tilbake til det om litt, lat oss fyrst vitje leigebeitet åt vestlendingane.

\section{Leigebeitet}

Turen frå Vestlandet og inn i fjella tek tid. Den våte vegen og det kontinuerlege regnvêret et mesta opp lyset frå bilen, og køyreforholda understrekar lengda på «fjellvegen» åt vestlendingane.

Heile leigebeitet er privat eigedom. Og eigarane er dei som har dei opphavlege gardsbruka som ligg langs hovudvegen som går gjennom denne i dag så gentrifiserte vintersportsbygda. Utmarka der beiteområdet ligg, er delt opp i tre om lag jamstore gardar som det heiter. Og sjølv om innmarka og litt av det heimenære skogs- og utmarksbeitet er delt opp i bruk, ${ }^{3}$ er likevel mesteparten av utmarka sameige mellom bruka som høyrer til kvar av dei tre gardane. Totalt består dei tre gardane av mellom 12 og 14 bruk i dag. Berre eit lite fåtal, fire eller fem, av bruka er aktive gardsbruk drivne av dei som bur på bruka. Og alle driv dei med mjølk- eller ammekyr i dag, og det er lenge sidan dei slutta med sau her.

Morgonen etter tenkjer eg å sjå litt nærare på beiteområdet. I det eg svingar inn stølsvegen i retning der vestlendingane slepp sauen sin på beite, står sola i ryggen og syner meg eit vakkert beitelandskap. Her har det vore aktiv beiting i generasjonar, fyrst av dei lokale bøndene, men sidan sist på 6o- og fyrst på 70-talet har altså desse vestlendingane beita her.

- Det hadde ikkje sett slik ut $i$ dag om det ikkje var for leigebeitarane, hadde ein av grunneigarane fortalt meg på telefon dagen før. Og med det

3 Denne måten å dele inn eigedom på, altså i gards- og bruksnummer, er ein del av matrikkelen og er typisk for dei fleste land som me kan samanlikne oss med. 
understreka han det min kollega Yngve Rekdal har fortalt meg gong på gong, nemleg at eit beite lyt beitast om kvaliteten skal vare (Jf. Rekdal, 2011).

- For det er reiseliv som tel her oppe i dag, sa bonden på telefon og sikta med det til den rivande utviklinga tettstaden litt lenger sør for heimegarden hans har hatt dei siste par-tre tiåra. Med eit topp moderne skianlegg og tilhøyrande hyttebyar har dette vesle bygdesamfunnet blitt transformert til ein pulserande «resort», fyrst som ein vinter-resort, men etter kvart også meir og meir som ein sumardestinasjon. Og møtet med reiselivet skulle også endre kvardagen åt leigebeitarane berre få år etter at dei tok i bruk beitet.

- Dei fyrste åra gjekk alt veldig greitt. [...], men sist på 9o-talet, ja kanskje litt før det også, så kom det mykje hytter. [...] Samstundes var det som hyttefolket starta irritere seg meir over sauen, fortalde leiaren i beitelaget meg.

- Ja, hugsa du jordborplanta? skaut den eine av beitelagsmedlemmane inn, og innskotet sette karane på ein latter. For då var det ein av hytteeigarane som hadde hatt to jordbærplanter i eit bildekk på tomta, og sjølvsagt hadde ein sau funne delikatessa og forsynt seg av den.

- Han var så sint at eg trudde han skulle eksplodere. Hytteeigaren hadde truga med saksøking om ikkje beitelaget erstatta jordbærplantene.

- Me fekk fleire brev frå ein advokat ... (namn på advokatkontoret) ..., brev skrive slik berre advokatbrev er skrivne.

Det er klart slikt kan vere vanskeleg å følgje opp. Og for beitebrukarane var dette ein uforholdsmessig sterk reaksjon for to jordbærplanter i eit bildekk, men samstundes var det ei sterk påminning om kor store ressursar enkelte kunne vere villige til å mobilisere for å forsvare det beitebrukarane såg på som små tap.

- Men var det ikkje inngjerda då?, spurde eg i min naivitet.

- På eit vis, sa ein annan, men det gjerdet kunne ein toåring sett opp betre. 
For sjølv om det skal vere inngjerda rundt hyttene, så er det berre eit fåtal som evnar å sette opp eit gjerde som faktisk held ein sau ute, fortalde beitebrukarane. Dei har opplevd store utfordringar med gjerding kring hyttene. Enkelte gjerde kunne også vere direkte farlege for sauen, fortalde dei. Og sjølv der det var gode gjerde, vart ofte portar ståande opne, og somme av portane slår innover slik at dyr som rotar seg inn på ei tomt, kan risikere å tørste ihel om porten legg seg att bak dei. I tillegg vart det også meir vanleg at laushundar jaga sau.

- Du veit, desse folka tenkjer ikkje på at hundane deira eigentleg er rovdyr, for dei er då så søte og snille med ungane.

Så etter kvart som problema synte seg, vart det naudsynt for beitebrukaren som hadde heftet ${ }^{4}$ sitt nærast hytteområdet, å flytte flokkane sine lenger inne i terrenget. Det var eigentleg ganske vanskeleg, men då ein av dei andre brukarane likevel skulle legge ned drifta si, så kjøpte han livdyr frå han og blanda saman nokre av sine gamle dyr for å prøve å hefte dei til hans heft.

- Men det var alltids enkeltdyr som trekte ned att mot der dei var vant å vere, så me vart plaga lenge med etterverknadane. I tillegg går det ein DNT-sti rett igjennom, og sarleg folk som går frå vest til aust, tek ofte med dyr framom seg, og gradvis vert dei ført nedover. Og så er beitet knallbra der, så det er ikkje løye at dei vil dit.

Framover på 200o-talet lærte beitebrukarane seg å leve med hytteområda, dei greidde å hefte flokkane sine lenger inne i fjellet, og sjølv om det enno skjer at nokre dyr søkjer seg inn mot hytteområda, greier dei som går tilsyn, stort sett å halde dyra derifrå. Men det går utover anna tilsyn, meiner dei, dei nyttar meir tilsynstid aust i området (altså nær hytteområda) no enn kva dei gjorde før hyttene kom, noko som går utover tida dei helst ville ha nytta lenger inne i fjella. For i beiteområdet vestom deira beiteområde har fleire flokkar forsvunne. Bønder har lagt ned, og no er

4 Ordet «heft» nytta i denne samanhengen tyder eit lauseleg definert område innanfor eit større beiteområde der ein beitebrukar prøver å få flokken sin til å beite frå år til år og gjennom heile sesongen. Å ha ein flokk som «heftar» godt, gjer tilsynet enklare og tilveksten betre. Det er ulike dialektale nemningar på dette kring om i landet, men eg vel her å nytte nemninga eg sjølv lærte frå mi eiga heimbygd på søre Sunnmøre. 
fleire av flokkane som deira flokkar brukte støyte mot, vekk. Dermed skjer det at sauene vandrar lenger vestover enn dei gjorde før. For sauen er ein slags revirhevdar, den vil gjerne ikkje sleppe inn andre flokkar på sine område, og slik bidreg dei ulike flokkane til å halde kvarandre på plass. Dei gjeter kvarandre, kan ein seie, og konsekvensen av at ein flokk forsvinn, er ofte at andre flokkar vandrar inn på det «ledige» området.

Sist på 90-talet og framover på 200o-talet merka beitebrukarane også at jamt fleire folk starta vandre i fjellet. Ikkje berre er det fleire av dei, men dei vandrar også på ein annan måte, ofte «i større grupper» og ofte «i større fart», som ein formulerte det. Alt skapte meir uro i fjellet. Men enno var det som skulle kome vinteren 2018, ukjent.

\section{Utestenginga}

Vinteren 2018, berre nokre dagar før dei skulle fornye leigekontrakten for nye 10 år, fekk beitelaget eit varsel om oppseiing av leigeavtala frå dei tre grunneigarane som eig den synste tredjedelen av beiteområdet som dei no hadde leigd i nær 50 år. Beitebrukarane forstod lite av dette og ville ha møte med grunneigarane i von om å finne ei løysing. På møtet stilte grunneigarane med advokat, og dei ga lite anna forklaring enn at dei skulle utvikle jakt-turisme i området, at dei meinte sauen fortrengde villreinen frå området, og at det derfor ikkje var mogleg å kombinere sauebeite med villreinjakt.

Beitebrukarane kom ingen veg med grunneigarane på dette, og ikkje fekk dei mykje hjelp frå korkje fylkesmannen eller andre offentlege instansar. Så gradvis har dei innsett at dette er ei tapt sak.

- Korleis kan grunneigarane berre stenge oss ute? Og i tillegg fordi det skal jaktast rein der, det har vel aldri vore noko snakk om at sau og rein ikkje går $i$ hop?

Ja, sei det, tenkjer eg. Eg er ikkje i stand til å finne nokon vitskapleg dokumentasjon for at sau fortrenger villrein. Men så er eg heller ingen villreinforskar, eg er ikkje anna enn ein vanleg villreinjeger som rett nok har jakta i terreng der sauen så vel som villreinen har levd nokolunde greitt i hop. Men eg har høyrt jegerar klage på «all sauen». Helst har eg trudd 
det har handla om at enkeltjegerar har opplevd at ein har skremt opp sau når ein har stilt på dyr, og det kan sjølvsagt spolere ein sjanse. Likevel har eg ikkje grunnlag for å tvile på grunneigarane sine motiv her. Dei fortel at jegerane med den største betalingsviljen ikkje ønskjer sau i området, og slik sett kan ein forstå argumentet. Dermed set eg att med det same spørsmålet som beitebrukaren stilte; korleis kan dei berre stenge ute beitebrukarane?

\section{Landbruk pluss og kunsten å selje landet}

Utestenginga så vel som hytteområda, dei nye og jamt fleire fjellvandrarane, laushundane og dei dårlege gjerda, er alt del av det same. Det er ein del av den nye økonomien, ein del av endra økonomiske og kulturelle forhold i samfunnet, og til saman utgjer det grunnlaget for dei politiske endringane som utmarka så vel som grendene er råka av (Flø, 2013; 2015). Skilnaden mellom den nye og den gamle økonomien ligg i relasjonen mellom produksjon og forbruk, hevdar den britiske geografen Paul Cloke (1993). Den ligg i at dei rurale områda i aukande grad har vorte gjenstand for forbruk og ikkje einast produksjon (Lowe et al., 1993). Der den gamle $ø$ konomien produserte mat og fiber til eksport ut av bygda, varer som i all hovudsak vart konsumert i byane og tettstadane, inviterer den nye økonomien folk inn i grendene for å konsumere vara der. Og vara i den nye $ø$ konomien er av eit anna slag enn vara i den gamle økonomien. Den er ikkje like eksportvenleg kan ein sei, anna enn den er stadbunden og fest i grenda. Den nye vara er det rurale, den er landskapet og den rurale kulturen, estetikken og stemninga (Flø, 2013; 2015). Utestenginga, hytteområda, fjellvandrarane og dei dårlege gjerda kjem som ein konsekvens av kommodifiseringa som Flø og Flemsæter skriv om innleiingsvis i denne boka. Og kommodifiseringa kjem som ein konsekvens av dei før nemnde økonomiske og kulturelle forholda i samfunnet som var fundamentet den tidlegare venstrestatsråden Lars Sponheim tufta sin «Landbruk +»-politikk på, då han sat som landbruks- og matminister i 2002 (St. prp. nr. 70, 2002-2003). For størstedelen av den urbane øvre middelklassa hadde alt starta etterspørje den vara Sponheim ville legge til rette for å produsere, då han la fram sine endringar i verkemidla for 
landbruket. Dei hadde starta søkje seg to tre timar ut i byane sine rurale omland for å nyte det «gode livet på landet» i feriane og dei ovale helgane. Dei hadde oppdaga Distrikts-Noreg sine kvalitetar som ein stad der dei kunne oppleve, nyte og konsumere. Og det var det Sponheim meinte bøndene måtte få lov å nytte som kjelde for økonomisk verdiskaping. «Ta heile gardens ressursar i bruk» var mantraet Sponheim stadig repeterte og meinte med det at utmarka, som så lenge no hadde mesta lege brakk som produksjonsareal for jordbruket, skulle takast i bruk på nye inntektsbringande måtar (Sponheim, 2003). No skulle arealressursar så vel som jakt og fiskerettar, alt saman ressursar som ligg til grunneigaren, utviklast til næring for å spe på fallande jordbruksinntekter (Flø, 2015). Grunneigarorganisasjonane som Bondelaget så vel som Skogeigarlaget støtta Sponheim sine planar. Dei gjekk saman med Reiselivsbedriftenes landsforening og fekk laga ein rapport som hevda at det låg eit verdipotensial i utmarka på svimlande 8 milliardar kroner årleg (Reiselivsbedriftenes Landsforening \& Norges Skogeierforbund, 2004).

Men Sponheimen er ikkje aleine ansvarleg for denne iveren til å selje både utmarka og det rurale. Like mykje lyt eg, og kanskje også du som les dette, ta vår del av ansvaret. Vanlege folk så vel som både byråkratar og forskarar var alle ein del av det same. Me likte den nye given som skjedde i Bygde-Noreg, me likte grotteostane, dei delikate og kostbare spesialskinkene, og me likte å få servert kjakekjøt frå lokalt urfe på fjellstovene.

\section{Likskap og ulikskap i den rurale idyll}

Slik vart den nye bygda. Godt hjelpt av FoU-miljøa, kunnskapsprodusentane i forskinga og utviklingsagentane i dei mange bygdeutviklingsprosjekta vart jamt fleire av oss byborgarar med eksamenspapir frå universiteta og høgskulane stimulerte til å søkje oss til bygda for å få eit glimt av det me likte å tru var det autentiske Noreg. Me sette oss til bords i ombygde føøs og sel og åt den lokale maten og høyrde på forteljingane om kor tradisjonell den var. Me fekk kjenne på kjensla av å vere knytt til lange kulturelle tidsliner som gjekk lenger attende enn vår eiga førestillingsevne. Og me opplevde gleda av å vere kulturelt knytt til noko som var større enn oss sjølve, til landbruket, fiskeriet og «det gode livet på landet». 
Den amerikanske bygdesosiologen Michael Bell (2007) hevdar at det skjedde ei «kulturell vending»5 i bygdeforskinga og seinare i bygdeutviklinga frå midten på 1990-talet og fram mot tusenårsskiftet. Her trekkjer han fram særleg dei britiske bygdeforskarane som hadde late seg inspirere av kjende franske filosofar som mellom anna Debord og Baudrillard, og starta antyde at symbolikken var i ferd med å få forrang framfor materialiteten. Og med den erkjenninga tok bygdesosiologien eit steg i retning det kultursosiologiske og vekk frå den dominerande sosioøkonomiske retninga som hadde dominert disiplinen så lenge. Frå mesta einast å ha vore opptatt av materielle faktorar som vegar, arbeidsplassar, folketal og liknande, skapte den generelle kulturelle vendinga ein bygdesosiologi som vektla omgrep som meiningsinnhald, identitet og representasjon. Og etter kvart som det vitskaplege miljøet tok opp i seg desse omgrepa, fekk dei også auka gjennomslag i bygdeutviklingsarbeidet. Bygdene og det rurale vart tydelegare knytte til nettopp førestillinga om «den rurale idyll» (Halfacree, 1995; Jones, 1995; Halfacree, 2006). Ei førestilling som ifølgje Arnljot Løseth (1991) også vart ala fram og gitt liv av nettopp forskinga, då mykje av litteraturen om sosiale relasjonar i bygdesamfunna vart skapt i eit bilete av det «like» bygdesamfunnet. Idealiseringa av bygdesamfunnet har med andre ord bidrege til å skjule faktiske ulikskapar.

Bygdefolk er ikkje likare enn anna folk, men like ulike som andre. Dei har ulike liv og ulike interesser. Og sjølv om me veit at dei fleste bøndene bur på bygda, så er ikkje dei fleste som bur på bygda, bønder. Tvert om, også der er bøndene i stort mindretal, og i takt med strukturendringane vert mindretalet jamt tydelegare. Truleg er størstedelen av bygdefolka likare byfolka enn bonden i nabolaget. Dei har sine jobbar på kontor, butikk eller sjukehus. Nokre er skodespelarar, finansfolk eller forskarar, medan andre er heimehjelper, elektrikarar eller offiserar. Og berre ein og annan er bonde. For i bygdene så vel som i byane har moderniteten fungert om lag på same måten. Me fekk industrialisering og automatisering, folk tok seg høgare og høgare utdanningar, og primærnæringane til liks med den manuelle industrien sysselset stadig færre og ein jamt mindre 
del av befolkninga. Så bygdefolk flest er i dag som byfolk flest. Dei lever sine liv mellom arbeid og fritid, dei køyrer borna på trening og går sjølve på café med c. Dei har om lag like lite å gjere med landbruket som kva byborgar som helst, for slik er den nye bygda.

\section{Fråkoplinga}

Utviklinga i det rurale Noreg dei siste 50-60 åra skil seg vesentleg frå utviklinga me kjenner frå våre kontinentale grannar og ikkje minst frå utviklinga i Storbritannia. Den skil seg også frå utviklinga i våre geografiske og politiske nære naboar i Norden som både Sverige, Finland og Danmark. Håvard Teigen (1999) forklarer dette skiljet med det han kallar «den særnorske distriktspolitikken» og meiner «målsettinga om å halde oppe hovudtrekka i busettingsmønsteret har vore eit særnorsk fenomen» (s. 203). Derfor har distriktsomsuta prega store delar av dei innanlandske politikkområda. Til skilnad frå mange av våre granneland, der distriktspolitikken har vore mesta einstydande med landbrukspolitikk, har den norske distriktspolitikken prega nærings- og industripolitikken, forsvarspolitikken, sosialpolitikken og dei fleste andre politikkområda. Det er også grunnen til at våre utanlandske turistar som reiser gjennom dette landet, anten dei sit i bubilane sine eller dei står langs rekka på dei tungoljedrivne turistmaskinene på veg inn ein av våre mange fjordarmar, vert slått av den rurale rikdomen (Vinge \& Flø, 2012; 2015). For her bur det folk utan at dei har noko som helst med korkje landbruk eller fiskeri å gjere, her ligg velstelte hus og heimar spreidd ut i landskapet busett av folk i heilt andre sektorar enn primærnæringa. Her finst det høgteknologiske småbedrifter som har heile verda som oppdragsmarknad, her finst det kunst og kulturinstitusjonar av høg kvalitet, institusjonar ein elles i verda einast finn i storbyar, her finst det små tettstadar med urbane fasilitetar, og her finst (enno) knapt rural fattigdom. Der Danmark har sin «rotne banan» langs landets bakside - kystlinja frå Nord- til Sør-Jylland inkludert Bornholm - har Sverige erkjent sine djupe sosiale utfordringar i innlandskilen som strekker seg frå Norrbotten og langt inn i det indre Dalarna. Men i Noreg rår (enno) velstanden kring om i bygdene. Rett nok finn me det eg tidlegare har omtala som «enkelte rotne druer» her til lands (Flø, 2017) - altså stadar og lokalsamfunn prega av einsidig 
næringsstruktur og tilhøyrande sosial deprivasjon - men det er ikkje like tydeleg knytt til regionar og samanhengande rurale område som hjå våre naboland.

Paradoksalt nok er dette også bakgrunnen for den utfordringa dei tradisjonelle brukarane av utmarka møter i dag. Det jamt meir mangfaldige rurale næringslivet og den relativt store offentlege sektoren har skapt ei breiare sosial og kulturell samansetjing i den norske bygde- og distriktsbefolkninga. For saman med utviklinga i landbruket dei siste par generasjonane, og særleg relasjonen mellom innmark og utmark slik det er skildra både i introduksjonskapittelet i denne boka og også i den innleiande forteljinga i dette kapittelet, er dette ei forteljing om eit jordbruk som har vorte meir og meir fråkopla lokalsamfunnet. Frå å ha vore mesta som ein alle-manns-aktivitet der så godt som alle i grenda hadde fyrstehandsrøynsler med både jordbruk og det å ha beitedyr i utmarka, er me no i ein situasjon der berre eit lite fåtal av grendas innbyggarar har slik kjennskap. I vårt konkrete tilfelle, altså i dette beiteområdet som me her snakkar om, er ikkje beitebrukarane eingong busett i lokalsamfunnet der grunneigarane og dei andre utmarksbrukarane bur. Dei bur meir enn 2 timar med bil lenger vest, på den andre sida av fjellet, bokstavleg talt. Dei har i alle år stort sett berre snakka med den grunneigaren som til ei kvar tid har vore leiar av grunneigarlaget her, dei andre grunneigarane har dei knapt sett. Derfor kjenner beitebrukarane og dei lokale utmarksbrukarane kvarandre dårleg, derfor er det lett å ignorere behova åt kvarandre, derfor er det lett å snakke forbi kvarandre, derfor er dei framande for kvarandre.

Sameleis er størstedelen av dei andre utmarksbrukarane også meir eller mindre fråkopla lokalsamfunnet. Dei er som meg - og kanskje også som deg som les dette - me reiser langt til hyttene våre, me køyrer i 2 til 3 timar, frå byar og tettstadar, til ei oval helg i naturen. Og me ser ikkje alltid røyndomen slik dei lokale ser den. Me ser ikkje alltid verdien av beitedyra, me berre skimtar dei somtid på langt hald inst inne i fjella. Me kjenner ikkje beitebrukarane, kanskje møter me dei av og til, helst når dei går tilsyn, men me kjenner dei ikkje. Me veit ikkje kven dei er, me veit ikkje kva dei gjer, me veit ikkje kva det vil seie å gå tilsyn eingong. Me er kort sagt fråkopla. Slik er den nye utmarka. 


\section{Asymmetri - makt og interessemotsetnadar}

Med den nye bygda, dei jamt meir ulike interessene og dei stadig meir ulike bakgrunnane åt sambygdingane, den nye bruken av utmarka og dei nye brukarane, har også forvaltinga av utmarka blitt langt meir komplisert. Kvar einskild har fått meir ulike interesser, og ofte står interessene mot kvarandre, ofte er det vanskeleg å sameksistere og finne gode kompromiss.

- Gamle grannar som før stod skulder til skulder med oss og gjerde utgard, står no mot oss og kranglar om kven som har ansvar for å vøle den same utgarden, fortalde ein beitebrukar i Nordland.

Liknande motsetningar finn me i alle våre caseområde, skigåarar står mot skuterkøyrarar, fjellvandrarar står mot jegerar og hytteeigarar mot beitebrukarar. Færre av utmarksbrukarane er litt av alt, færre er både skigåar, fjellvandrar og beitebrukar, og fleire er lengre frå beitebruken enn nokon gong før. Sjølv dei private eigarane av utmarka er i dag meir ulike, der så godt som alle hadde gard og husdyr, er det i dag berre mindretalet som driv med slikt. Ein gradvis aukande del av dei private grunneigarane i utmarka har lagt ned gardsdrifta, kanskje er dei også busett ein stad langt vekk der dei skjøttar sine jobbar i olje, finans eller offentleg sektor. Kanskje har dei skifta frå matproduksjon til kultivering av opplevingar i utmarka, kanskje deler dei det vesle familiesmåbruket med sine sysken, eller endåtil syskenborn, som ein rekreativ andreheim i ferier og ovale helgar. Kanskje treng dei kapital til å sikre framtida for eigne born som forlengst har fest seg til andre stadar i landet enn småbruket der mor voks opp, kapital som Fred Olsen Renewable eller andre utbyggarar er meir enn villige til å stille opp med mot ei avtale om å få utvikle arealet for sine prosjekt. Uansett er det rimeleg at fleire av dei med rettar i utmarka har jamt meir ulike interesser i utmarksbruken, interesser som ofte kan stå mot kvarandre.

Men kva gjer desse ulike motsetnadane med oss? Kva gjer det med beitebrukarane, med bygda så vel som med utmarka at stadig fleire av dei med eigedoms- eller bruksrettar får jamt meir ulike interesser? Min beinveges tanke når eg høyrer beitebrukarane snakke, går til ein 
vidgjeten artikkel av Elinor Ostrom ${ }^{6}$ frå 1998. Under tittelen «A Behavioral Approach to the Rational Choice Theory of Collective Action: Presidential Adress» (Ostrom, 1998), teiknar ho opp ein skjematisk modell for kva som avgjer utfallet av samarbeid mellom menneske. På mange måtar definerer denne artikkelen Ostrom sin vitskapsteoretiske ståstad, men det er særleg ein del av modellen eg tenkjer beitebrukarane sine forteljingar røyver ved.

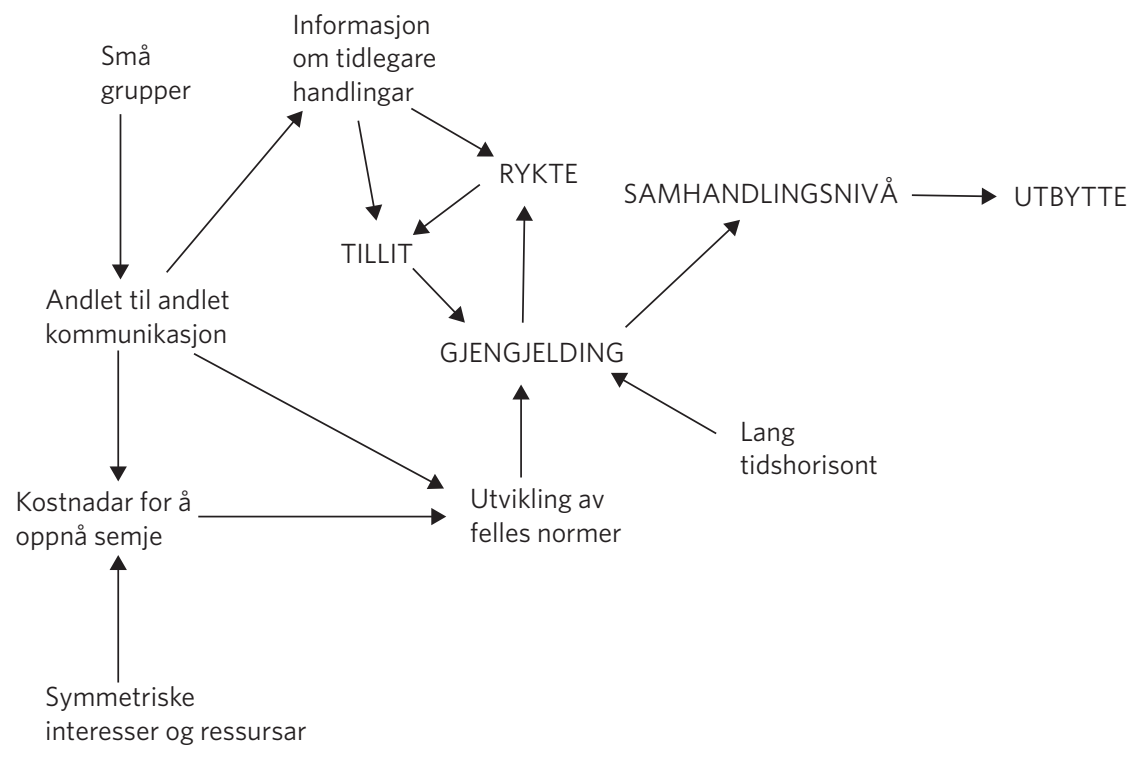

Figur 1. Med denne modellen syner Ostrom oss ei forenkla skildring over korleis ulike faktorar innverkar på eit samarbeid. Modellen er henta frå Ostrom (1998) og her omsett til norsk.

Nedst i venstre hjørne av modellen (figur 1) har Ostrom sett inn «symmetriske interesser og ressursar». For grad av symmetri mellom dei ulike aktørane sine interesser og ressursar er avgjerande for evna til å «utvikle felles normer» for korleis me ter oss i høve til kvarandre når utmarka og utmarksbruken skal forvaltast. Og det er nett det beitelagsmedlemmane, så vel som grunneigarar og andre som eg har snakka med i dette prosjektet, fortel ikkje er til stades. Tvert om er dagens utmark

6 Elinor Ostrom er kjent som ein av verdas fremste forskarar innan forvalting og styring av fellesressursar. Ho vart også tildelt den sokalla «Nobels minnepris i økonomi» i 2009 for sitt vitskaplege bidrag til samfunns- og økonomifaget. 
prega av stor asymmetri når det gjeld dei ulike aktørane i utmarka sine interesser så vel som ressursar. I tillegg fortel både historia om dei to jordbærplantene og fleire liknande historier eg har fått høyre, at viljen til å sette inn ressursar i kampen for eigne interesser kan vere uhøveleg stor til tider.

Med moderniteten, med den kulturelle vendinga i forskinga så vel som i forvaltinga, og Sponheim si satsing på å «ta heile gardens ressursar i bruk», har andre interesser teke ein sentral posisjon i «kampen» om utmarka. Fritidsinteresser, og særleg interesser som søkjer å skape næring ut av fritidsbruken, har fått ein meir sentral plass i politikk og forvalting. I dag er me vitne til at den tradisjonelle beitebruken også vert påstått å vere skadeleg for klimaet. Beitebrukarane opplever at dei tapar til fordel for andre brukarar. Dei fortel om manglande forståing frå forvaltinga så vel som frå folk flest for den kvardagen og dei utfordringane dei møter i kvardagen som følgje av auka ferdsel og bruk av utmarka til fritidsføremål. Dei opplever at dei vert tilsidesett og ignorert, samstundes som fritidsbruken og dei nye næringane som veks opp i samband med den aukande fritidsbruken, vert løfta fram som framtidsnæringar. Mange av beitebrukarane eg har snakka med i samband med dette arbeidet, fortel at fritidsbrukarane for berre få år sidan synte langt meir forståing for beitebrukarane sine kvardagsbehov enn kva dei gjer i dag. No vert bøndene jamt oftare møtt med det dei sjølve opplever som sinne og urettvise skuldingar. Og alt tærer på motivasjonen så vel som på sjølvkjensla, og når no den dagsaktuelle debatten om klima og drøvtyggarar legg seg oppå det heile, gir det lita von om endringar i beitebrukarane sin politiske posisjon. Den krympande vona røyner på motivasjonen hjå dei som heile livet har trudd det dei gjer, er rett for både oss og dei.

\section{Når det sjølvorganiserte lokale forvaltingskollektivet raknar}

Sidan eg no har introdusert Elinor Ostrom, er det freistande å halde fram i sporet av hennar forsking. Gjennom eit solid empirisk og teoretisk arbeid, mellom anna publisert i boka Governing the Commons frå 1990, irettesette ho den då dominerande oppfatninga om at allmenningar 
(commons) og andre regime for felles forvalting av sokalla fornybare fellesressursar (CPR) ${ }^{7}$ ville føre til det Garrett Hardin (1968) kalla ein tragedie. Ostrom argumenterte med at allmenningar eksisterer og dei har eksistert både lenge nok og godt nok til at dei har synt seg berekraftige over tid, ja endåtil meir berekraftige enn både privat- og offentleg eigde ressurssystem, som var Hardins svar på den påståtte tragedien. Ein av hovudgrunnane til suksessen åt allmenningen, seier Ostrom, er at allmenningsbrukarane ikkje opptrer som reine homo economicus. ${ }^{8}$ Tvert om er dei sosiale og tett vovne saman i lokale nettverk (lokalsamfunn) der dei samtalar og samhandlar, der dei overvakar og sanksjonerer kvarandre og slik produserer og formidlar dei felles normer som gjeld for korleis folk lever saman som menneske (Ostrom, 1990, s. 15-21). Og det er nett det eg har sett rakne no på mine turar kring om til lokalsamfunna i dei fire landsdelane det siste året. Dei tette sosiale banda, det sosiale livet i lokalsamfunna, er ikkje like tett i veven lenger. Og skal beitebrukarane styrke sin posisjon - sosialt så vel som politisk, økonomisk og juridisk lyt ein vere merksam på denne viktige endringa og sette inn ressursar på å vøle det og ikkje einast pønske ut korleis ein skal få ned kostnadane i samband med fjøsbygging, forbetre kvaliteten på vinterfôret eller få fleire lam på søyene, for sjølv om det òg er viktig, så løyser det ikkje dei største utfordringane for beitenæringa.

Det som skjer i utmarka om dagen, kan seiast å vere i slekt med det skiftet i dei sosiale relasjonane mellom samfunnets elite og allmenningsbrukarane som Ellen Meiksins Wood (2002) skildrar i si framstilling av privatiseringa av dei engelske allmenningane på 1600- og 1700-talet. Rett nok er det ikkje nødvendigvis einskildaktørar som private gods- eller grunneigarar som representerer eliten her heime i dag, men derimot den jamt veksande gruppa av ei velståande øvre middelklasse.

7 Ostrom studerer det som på engelsk vert kalla «commons». Sjølv om det lyt forståast som meir enn einast det me her til lands kallar allmenning, vel eg likevel å nytte omgrepet allmenning i dette essayet. Sameleis vel eg og omsetje Ostrom sitt omgrep «Common pool resource» (CPR) til fornybare fellesressursar.

8 Omgrepet «homo economicus», eller økonomisk menneske, er ei skildring av menneske som agentar som konsekvent er rasjonelle, dominert av snevre sjølvinteresser og som forfølgjer sine subjektivt definerte mål optimalt. 


\section{Middelklasseeliten og deltakardemokratiet}

For det er dei ... eller kanskje kan me seie oss, for det er fort at både den som skriv og den som les dette, høyrer til nett den klasse og stand som kan kallast den øvre middelklasseeliten. Det er me som byggjer hytter store som hus i dei beste beita langs seterdalane inn mot fjellheimen, det er me som et sunt og spring rundt i fjellet i lycra og goretex og let oss provosere av bygdeungdomar som tek scooteren til eit islagt fjellvatn for å prøve røya med pilkestikka. Me engasjerer oss i forvaltingsplanane og ropar om meir og strengare vern av naturen medan me tek til orde for fleire ulv, bjørn, gaupe og jerv.

Kanskje er også nokre av oss slike som Bühlmann et al. (2014) kallar liberale demokratar, slike som ønskjer å utvide forvaltinga til å omfamne ei breiare og større rådgivande deltaking i forvaltinga enn det me finn i dei sjølvorganiserte lokale forvaltingskollektiva, som tradisjonelt har vore dei som har drive med den aktive bruken og forvaltinga av utmarka? Kanskje ser me på det gamle lokale forvaltingskollektivet, typisk prega av at dei lokale utmarksbrukarane har fatta dei daglege operasjonelle vedtaka etter dei behova dei sjølve som brukarar har hatt, som eit system for å oppretthalde makta åt det lokale elitenivået?

Uansett har me - eller i alle fall nokre av oss - gradvis fått ein jamt sterkare posisjon i forvaltinga av utmarka. Me har organisert oss i ulike frilufts-, miljø- og interesseorganisasjonar og kravd å bli høyrt i spørsmål som mange lokale - særleg dei tradisjonelle brukarane - opplever er for dei å avgjere. Og me har hatt støtte i den rådande politiske tidsånda som har festa så godt grep om politikken etter at epoken Berge Furre ein gong kalla «den sosialdemokratiske orden» (Furre, 1992) vart erstatta av det me kan kalle «den ny-liberale orden» (Flø, 2018). Frå utpå 1980-talet og framover vart det jamt vanlegare med breiare og breiare høyringar i forvaltinga (Selle, 2004). Gjennom å utvide definisjonen av interessegrupper oppnådde forvaltinga nok sprik i høyringane til at ein kunne hevde å ha teke omsyn til alle innspela utan å måtte gjere noko med det opphavlege planutkastet.

Parallelt med denne utviklinga, og kanskje som ein reaksjon på at dei liberale demokratane fekk eit så sterkt fotfeste i forvaltinga, starta dei Bühlmann et al. (2014) kallar «dei radikale demokratane» å kome 
på banen. Med profilar som mellom anna Ernesto Laclau og Chantal Mouffe voks den radikale demokratiske rørsla fram som ein respons på det fleire såg som ei elitistisk forvalting forhandla fram av eit mangfald av sterke og godt organiserte interessegrupper. Dei var misnøgde med det dei såg som ei svekking av demokratiske prinsipp som skjedde ved denne elite-nivå-forhandlinga mellom eit mangfald av interessegrupper (Deleixhe, 2018). Dei radikale demokratane var i stor grad inspirerte av Ostrom sitt arbeid og såg på det sjølvorganiserte forvaltingskollektivet som eit essensielt verktøy for generelle demokratiske prinsipp. Samstundes kritiserte dei Ostrom for å mesta ignorere eksistensen av konflikt internt i forvaltingskollektiva. Ho teikna eit harmonisk og mesta idyllisk bilete av det sjølvorganiserte lokale forvaltingskollektivet, hevdar Mouffe (2005) og understreka den dynamiske rolla dei agonistiske eller mesta kampliknande konfliktane eit mangfald av interessemotsetningar vil ha for forvaltinga.

\section{Sterkare stemmer og svakare rettar}

Sjølv har eg ikkje sett at mangfaldet av interessemotsetnadar har betra forvaltinga. Og ikkje ser eg at Ostrom ignorerer eksistensen av konflikt heller, slik dei radikale demokratane hevdar. Tvert om presiserer ho at konfliktar eksisterer, og at det trengst effektive konfliktløysingsmekanismar. I det sjette av dei til saman åtte forvaltingsprinsippa ho dreg opp i boka Governing the commons (Ostrom, 1990), er ho også eksplisitt på nettopp det. «Rettshavarane treng rask tilgang til rimelege lokale arenaer for å løyse konfliktar både internt mellom rettshavarane og mellom rettshavarane og den offentlege forvaltinga» (s. 100-101), seier ho. Og i figuren som eg har henta frå hennar artikkel (figur 1), ser me også at når asymmetrien mellom brukarar og interessentar aukar, så aukar også «kostnadane for å oppnå semje». Sagt på ein annan måte så vert det for krevjande og for slitsamt for beitebrukarane å sjølve måtte forhandle med alle dei andre brukarane og interessentane i området for å få lov å sleppe sau på beite. Og framfor å teoretisere om alle moglege måtar å demokratisere forvaltinga av utmarka på, så tenkjer nok jamt fleire beitebrukarar slik som dei eg møtte i Trøndelag. 
- Det må då gå an å berre få nokre ekspertar inn her som kan fortelje forvaltinga kva som må gjerast om me ønskjer at det vert beita her om 25 år.

For sjølvsagt er det viktig å pønske ut måtar å gjere utmarksforvaltinga betre og meir demokratisk. Men me ser jamt oftare at sentrale så vel som regionale og lokale myndigheiter slit med å løyse konfliktar mellom tradisjonell utmarksbruk og snøscooterbruk, auka rekreasjons- og friluftsaktivitetar, hytteutbygging, etc. Men samstundes ser me - i alle fall me som les internasjonal forskingslitteratur - at dersom ein legg ressursar i å løyse slike konfliktar, der ein får dei relevante interessegruppene til å møtast til konfliktløysande samtalar, så vert det oppnådd semje, særleg om det vert nytta kompetente meklarar (Ellickson, 1991; Bergstedt et al., 1999; Vail \& Heldt, 2004; Zacharisson, 2009).

Sjølv om utmarka har vore assosiert med sjølvorganiserte lokale forvaltingssystem utan innblanding frå korkje stat eller marknad, så er det likevel viktig å hugse på at det ikkje er eit panacea (eit universelt lækjemiddel) for demokratiets mange veikskapar. Men så er det neppe demokratiets veikskapar beitebrukarane er mest uroa for om dagen heller, dei kjenner einast på kroppen at det vert jamt meir krevjande å dagstøtt merke motviljen frå sambygdingar, fjellvandrarar og rekreerande hyttegjestar. Dei ber berre om at «nokre ekspertar» skal ta ei rolle her, nokon med kompetanse på konfliktløysing, nokon som kan røyse den kapitalen som trengst for å dekke kostnadane som skal til for å løyse flokane som har oppstått mellom grannar og folk i fjellet. Så då vert spørsmålet: Kan me ta på oss den jobben?

\section{Litteraturliste}

Almås, R. (2002). Frå bondesamfunn til bioindustri: 1920-200o. Vol. IV, Norges landbrukshistorie. Det Norske Samlaget.

Bell, M. M. (2007). The two-ness of rural life and the ends of rural scholarship. Journal of Rural Studies, 23(4), 402-415.

Bergstedt, J., van den Brink, P. \& Vikman, P-Å. (1999). Vegetationsförändringar på fjällen i västra Härjedalen: en kunskapsöversikt. I Rapport Fjällforskningsinstitutet, Mitthögskolan. Fjällforskningsinstitutet, Mitthögskolan. 
Bjørkhaug, H. (2000). Ensomme bønder - myte eller virkelighet? Landbruksøkonomisk Forum (1).

Bühlmann, M., Vatter, A., Dlabac, O. \& Schaub, H-P. (2014). Liberal and Radical Democracies: The Swiss Cantons Compared, $10(2), 385$.

Cloke, P. (1993). The contryside as commodity: New rural spaces for leisure. I S. Glyptis (Red.), Leisure and the environment. Essays in honour of Professor J. A. Patmore (s. 53-65). Belhaven.

Deleixhe, M. (2018). Conflicts in common(s)? Radical democracy and the governance of the commons. Thesis Eleven, 144(1), 59-79.

Ellickson, R. C. (1991). Order without law. How neighbours settle disputes. Harvard University Press.

Flaten, O. (2017). Factors affecting exit intentions in Norwegian sheep farms. Small Ruminant Research, 150(4), 7.

Flø, B. E. (2013). Me og dei andre. Om lindukar, Framstegspartiet og bygda som sosial konstruksjon. Sosiologisk Tidsskrift, 21(2), 152-168.

Flø, B. E. (2015). Bygda som vare - om bygda, elgen og folkeskikken [Doktorgradsavhandling]. Norges teknisk-naturvitenskapelige universitet.

Flø, B. E. (2017). Det grøne skiftet og grendene - sentrum og periferi i den nye $ø$ konomien. PLAN (2), 26-29.

Flø, B. E. (2018). Av svik kom mistru sigande. Samtiden (1), 54-61.

Friedmann, H. (1982). The political economy of food: The rise and fall of the postwar international food order. American Journal of Sociology 88, S248-S286.

Furre, B. (1992). Norsk historie 1905 - 199o. Vårt hundreår. 4 vols. Vol. 4, Norsk historie. Det Norske Samlaget.

Halfacree, K. H. (1995). Talking about rurality: Social representations of the rural as expressed by residents of six English parishes. Journal of Rural Studies, 11(1), 1-20.

Halfacree, K. H. (2006). Rural space: Constructing a three-fold architecture. I P. Cloke, T. Marsden \& P. Mooney (Red.), Handbook of rural studies (s. 44-62). Sage.

Hardin, G. (1968). The tragedy of the commons. Science, 162(3859), 1243-1248.

Jones, O. (1995). Lay discourses of the rural: Developments and implications for rural studies. Journal of Rural Studies, 11(1), 35-49.

Lowe, P., Murdoch, J., Marsden, T., Munton, R. \& Flynn, A. (1993). Regulating the new rural spaces: The uneven development of land. Journal of Rural Studies, 9(3), 205-222.

Løseth, A. (1991). Nordvestlandet - egalitært eller stratifisert? I L. Marthinsen \& H. Winge (Red.), Bygdesamfunnet - en sammensatt helhet (s. 149-166). Norsk lokalhistorisk institutt.

Mouffe, C. (2005). On the political. Routledge.

Ostrom, E. (1990). Governing the commons. The evolution of institutions for collective action. Cambridge University Press. 
Ostrom, E. (1998). A behavioral approach to the rational choice theory of collective action: Presidential address. The American Political Science Review, 92(1), 1-22.

Reiselivsbedriftenes Landsforening \& Norges Skogeierforbund. (2004). Forprosjekt om Utvikling av utmarksbaserte reiselivsbedrifter - markedsmuligheter, mål, strategier og forslag til verdikjedeprogram. Reiselivsbedriftenes Landsforening og Norges Skogeierforbubd.

Rekdal, Y. (2011). Skjøtsel av fjellbjørkeskog for husdyrbeite. Skog og landskap.

Selle, P. (2004). Sterkere statsmakt og svekket lokaldemokrati. Nytt Norsk Tidsskrift, 21(1), 79-85.

Sponheim, L. (2003). Tale for Den nasjonale kongress for økologisk landbruk. 05.11. Hamar.

St. prp. nr. 70. (2002-2003). Om jordbruksoppgjøret 2003 - endringer i statsbudsjettet for 2003 m.m. Arbeids- og administrasjonsdepartementet. Oslo.

Teigen, H. (1999). Regional økonomi og politikk. Samfunnsøkonomi og økonomisk politikk. Universitetsforlaget.

Vail, D. \& Heldt, T. (2004). Governing snowmobilers in multiple-use landscapes: Swedish and Maine (USA) cases. Ecological Economics, 48(4), 469-483.

Vinge, H. \& Flø, B. E. (2012). På gjengrodde stier. I M. Rønningen \& T. Slåtten (Red.), Innovasjon og noringsutviklng i en reiselivskontekst (s. 279-296). Fagbokforlaget.

Vinge, H. \& Flø, B. E. (2015). Landscapes lost? Tourist understandings of changing Norwegian rural landscapes. Scandinavian Journal of Hospitality and Tourism, 15(1-2), 29-47.

Wood, E. M. (2002). The origin of capitalism: A longer view. Verso.

Zacharisson, A. K. E. (2009). Deliberative democracy and co-management of natural resources: The case of Funäsdalen snowmobile regulation area. International Journal of the Commons, 4(1), 273-292. 


\title{
KAPITTEL 4
}

\section{Kampen om utmarka: Hytter, beitemark eller urørt natur?}

\section{Jørund Aasetre}

\author{
Norges teknisk-naturvitenskapelige universitet (NTNU)
}

\begin{abstract}
In the Norwegian outfields (utmark), traditional agricultural use, nature conservation, tourism and second home development are opposing interests. This chapter focuses on the municipality of Oppdal and key discourses regarding future land use. Furthermore, how those discourses can lead to continuity or changes in the balance of power in relation to land-use management. The chapter is based on different sources. One is a project focusing on drawing up a master plan for destination development in Oppdal. Other sources include three years of experience holding field courses for natural resource management students at NTNU, in addition to a literature search. Four different discourses related to management of the outfields are identified. Second home development has been an important economic driving force in the local community, and one can identify this as a dominant discourse in the Oppdal community. Against this discourse, there are two other critical discourses. First, there is a discourse considering second home development as a threat to agriculture and grazing rights. The second is a nature conservation-oriented discourse that views second home development as a threat to nature values. As an attempt to bridge these opposing perspectives, a "win-win discourse" has been developed with a focus on sustainable second home development. The question is, does this represent a sufficient reorganization of land use or, on the contrary, represent a "greenwashing" of second home industry? This is an open question, but if we look at other environmental conflicts, then critical discourses often develop in opposition to such "win-win discourses". Either way, Oppdal is facing some major decisions in relation to future land management.
\end{abstract}

Keywords: sheep husbandry, second home development, recourse management conflict, nature management 


\section{Innledning}

Utmarka har gjennom lang tid vært en viktig ressurs for norske bygder. Bruken av utmarka og hvilke grupper som har interesser der har variert. I dette ligger både samforvaltning mellom ulike brukergrupper og maktkamp om hvem som skal ha tilgang til hvilke ressurser. Også i dag er det brytninger mellom ulike interesser, bruksformer og verdier i utmarka. Ulike interesser har ulik styrke og gjennomslag i samfunnet. Dette gjør makt til et viktig aspekt, ettersom resultatene fra lokale planog beslutningsprosesser ofte gjenspeiler maktforholdene i disse lokalsamfunnene.

Et slikt lokalsamfunn er Oppdal, som er en viktig hyttekommune i midtnorsk sammenheng. Samtidig er Oppdal en av de største sauekommunene i Norge (Aalbu, 2019), omgitt av store verneområder, samt har innslag av samisk reindrift. I planprosesser initiert av næringslivet er det formulert en målsetting om å bygge mer enn 100 hytter i året (Asplan Viak, 2013), samtidig som de beste hyttetomtene ofte ligger i områder som er viktige beiteressurser. Med tanke på arbeidsplasser synes det som en har gjort seg avhengig av kontinuerlig hyttebygging, med fare for å redusere arealene til andre interesser som naturvern og beitenæringer.

Oppdal er i dag en kommune med 7008 innbyggere (Statistisk sentralbyrå [SSB], 2020), og har et relativt stort sentrum med mange butikker i forhold til et tettsted av samme størrelse. I Midt-Norge er trondheimsregionen sterkt dominerende, men Oppdal har hatt en relativt positiv befolkningsutvikling sammenlignet med mange andre distriktskommuner i Trøndelag (Sliper, 2020). Ser en på befolkningsutvikling i MidtNorge fremkommer et tydelig mønster. Trondheimsregionen dominerer sterkt med positiv befolkningsutvikling, men også Innherred-byene utgjør et viktig befolkningsmessig tyngdepunkt. I Trøndelag utgjør så Oppdal, sammen med flere mindre regionalsentre (som Rørvik/Nærøysund), en gruppe kommuner som befolkningsmessig har holdt stand (Sliper, 2020). Oppdal som reiselivsdestinasjon kan nok være en viktig forklaring på dette.

I Oppdal-samfunnet betyr dette klare interessemotsetninger og diskurser om hva Oppdal skal være - hyttebygd, jordbruksbygd, naturparadis, eller kanskje er det mulig med en vinn-vinn-diskurs der en kan 
få til en bærekraftig hyttebygging som kan leve i harmoni med jordbruk og naturvern? I dette kapitlet vil jeg drøfte hvordan maktspillet i lokalsamfunnet har lagt grunnlaget for denne utviklingen, med utgangspunkt i følgende problemstillinger:

Hvilke diskurser søker å definere hovedutfordringene for fremtidig arealbruk i Oppdal kommune? Videre, hvordan kan ulike diskurser om Oppdalsamfunnets fremtid føre til kontinuitet eller eventuelle nye utviklingstrekk $i$ utmarkas maktbalanse?

Jeg vil først gjøre rede for kapitlets metodiske perspektiv og teoretiske rammeverk, et rammeverk som bygger på en politisk økologisk tradisjon. Med dette som bakgrunn ser vi nærmere på Oppdal som case, og de utfordringer Oppdal-samfunnet kan stå overfor i lys av disse ulike perspektivene. Avslutningsvis oppsummerer jeg funnene, og peker på trekk og tendenser som kan spille en rolle for fremtidens Oppdal.

\section{Metodisk perspektiv}

Dette kapitlet bygger på resultat fra eget prosjektarbeid, og erfaringene fra tre feltkurs i regi av NTNU sitt internasjonale mastergradsprogram i naturressursforvaltning. Studentene på kurset hadde enten spesialisering i biologi eller geografi. I tillegg deltok noen utvekslingsstudenter, samt noen lektorstudenter i geografi. I årene 2017, 2018 og 2019 tok feltkurset utgangspunkt i arealbrukskonflikter på Oppdal. I tillegg er det våren 2020 gjort noen supplerende litteraturanalyser. Metodisk kan kapitlet betraktes som å bygge på et såkalt «single-case-studium» (Yin, 2018), med empiri fra en kombinasjon av flere komplementære datakilder. Følgende tre kilder er benyttet:

1. Masterplan for reiselivsutvikling på Oppdal (Asplan Viak, 2013) og prosessen rundt denne er en viktig kilde for kapitlet. Arbeidet med masterplanen ble gjennomført av Asplan Viak i samarbeid med konsulentselskapet Posisjon og Menon Business Economics (nå Menon Economics). Prosjektet ble gjennomført på oppdrag av Oppdal næringsforening med finansering fra Innovasjon Norge 
og regionale og lokale næringsaktører. Oppdal kommune var også innforstått med og medvirkende i prosessen. Administrativ ansvarlig for prosjektet var Jørund Aasetre fra Asplan Viak, mens prosessledelsen var knyttet til Menon Business Economics. Prosjektet inkluderte både separate fagutredninger og flere medvirkningsseminarer. Metodisk ble prosessen gjennomført basert på Innovasjon Norge (2008) sin Hvitebok for reisemålsutvikling, dvs. en trefaset prosess: først en forstudie, deretter hovedplanleggingen etterfulgt av implementeringsfasen.

Medvirkningsdelen av prosjektet ble gjennomført ved to åpne folkemøter, samt gruppeprosesser hvor tema-utredninger ble gjennomført i mindre grupper med strategisk utvalgte aktører. Hovedtemaer var «nåsituasjon og ringvirkningsanalyse» (Enger et al., 2013), «konsept», «fellesgodefinansiering» (Sandnes et al., 2013) og «merkevare». Konseptutredningen var videre delt i undertemaene arealplanlegging, barmark og vinter. Dette medførte til sammen 6 strategisk sammensatte arbeidsgrupper med rundt 10 personer i hver gruppe. Hver arbeidsgruppe hadde i snitt 2-4 møter. Ideen var at gruppene skulle være bredt sammensatte, men representasjonen og synsvinkelen var nok noe preget av sterke næringsinteresser, dvs. ikke uavhengig av maktrelasjonene i Oppdal-samfunnet. Dette har nok til dels påvirket resultatet av prosjektet, selv om det hele tiden ble vektlagt å skape en bred tilslutning til prosessen lokalt.

Det første folkemøtet var basert på café-bord-metoden (Fouché \& Light, 2010), mens det andre var et mer tradisjonelt folkemøte. Møtene i arbeidsgruppene hadde mer preg av fokusgruppeliknende metodikk (Cameron, 2016; Krueger, 1994). Det ble utarbeidet skriftlige referat fra både folkemøtene og møtene i arbeidsgruppene. Folkemøtene ble gjort godt kjent i lokalsamfunnet, og det var godt oppmøte. Imidlertid garanterer ikke slike møter en representativ deltagelse. Det vil som regel være de mest interesserte som møter, ofte de som er «berørt» i positiv eller negativ forstand.

Informasjonen fra medvirkningsprosessen er en viktig del av grunnlaget for dette kapitlet. Der medvirkningsprosessen danner grunnlaget for utsagn, refereres det enten til Asplan Viak (2013), 
eller det henvises spesifikt til de ulike delene av medvirkningsprosessen (dokumentert gjennom møtereferat).

Fagutredningene under masterplanprosessen utarbeidet egne temarapporter, og disse refereres separat (se Enger et al., 2013; International Alpine Design, 2013; Sandnes et al., 2013).

2. Feltarbeid i naturressursforvaltning. En annen kilde til informasjon er arbeidet med tre feltkurs i naturressursforvaltning ved NTNU. Feltkursene til Oppdal varte i tre dager. Temaet for feltkursene var arealbrukskonflikter, og da spesielt knyttet til hyttebygging. Feltkursene ble gjennomført i september 2017, 2018 og 2019. I kursene hadde nøkkelinformanter presentasjoner for studentene. Dette omfattet folk i landbruks- og arealforvaltning i kommunen, i tillegg til informanter fra landbruket, hyttenæringen, skiferindustrien samt et lokalt utviklingsselskap. I snitt deltok ca. syv inviterte innledere hvert år, hvorav ca. 2/3 deltok alle tre årene. Presentasjonene fra de ulike innlederne varte omtrent 45 minutter. De ulike presentasjonene er med noen unntak dokumentert gjennom innledernes PowerPoint-filer. I samband med feltarbeidet ble det også gjennomført en rekke personlige samtaler med andre aktører i Oppdal-samfunnet, som oftest dokumentert gjennom egne notat eller studenters skriftlige semesteroppgaver. Der kilden er studentoppgaver er disse oppgitt i referanselisten.

Som ledd i feltarbeidet gjennomførte studentene også en mindre survey blant personer som oppholdt seg i Oppdal sentrum ettermiddagen 21. september 2017. Selv om undersøkelsen omfattet et begrenset antall $(\mathrm{N}=70)$, er hovedtendensene så klare at det gir et pålitelig bilde av folks oppfatninger om turisme og hyttebygging på Oppdal.

Erfaringene fra feltarbeidene ga ny kunnskap som utdyper bildet fra masterplanprosessen, og medførte nye fortolkninger av hva som kom frem under masterplanprosessen. Eksempelvis ga presentasjonene fra en sauebonde (samme person holdt innlegg i 2017, 2018 og 2019) et nytt blikk på mulige bias i masterplanprosessen. Slik sett bidrar disse kildene til bedre balanse. Aktører som er kritiske til hyttebygging og turisme kom bedre til orde under 
feltkursene. Det fikk meg også til å reflektere i hvilken grad jeg tidligere hadde vært et redskap for bestemte interesser i Oppdalsamfunnet. Dette på tross av at jeg hele tiden hadde til intensjon om å bidra til en balansert prosess.

3. Litteraturanalyse. I tillegg til erfaringene fra masterplanprosessen og studentfeltkursene, er innholdet i kapitlet supplert med søk og bruk av vitenskapelige artikler, kronikker og artikler i aktuelle aviser, samt nettsider til relevante aktører (alt fra Naturvernforbundet til regionale utviklingsaktører). Dette er informasjon som dokumenterer og underbygger utsagn og analyser i kapitlet. Dissa dataene ble dels samlet inn under masterplanprosessen og feltarbeidene med NTNU studentene, men i hovedsak supplert gjennom målretta nettsøk våren og høsten 2020.

Analysen i kapitlet lener seg i retning av en diskursanalytisk tilnærming, men da med en noe åpnere analyse av de sosiale og økonomiske valg Oppdal-samfunnet står ovenfor. Diskursanalyse rommer stor variasjon fra en streng lingvistisk tilnærming (Fairclough, 1992) til mer eklektiske tilnærminger (f.eks. Benjaminsen \& Svarstad, 2017). Tilnærmingen her er mer pragmatisk og åpen, og forsøker å identifisere ulike perspektiver på utviklingen av Oppdal-samfunnet.

Konkret er de ulike kildene til kapitlet lest og bearbeidet gjentatte ganger, og kategoriseringer og slutninger er trukket ut fra det Wadel (1991, s. 129) betegner som «Runddansen mellom teori, metode og data», dvs. noe tilsvarende en hermeneutisk tilnærming. For å sikre transparens er kilde oppgitt for alle empiriske påstander i kapitlet.

\section{Refleksjon rundt svakheter og styrker ved kapitlets datagrunnlag}

Dette kapitlet bygger på en sammensatt empiri som ikke er del av et felles prosjekt. Jeg har jobbet med spørsmål rundt arealforvaltning på Oppdal helt fra begynnelsen av 2012 og helt frem til høsten 2019. Dette gir en dypere innsikt i hvordan arealforvaltningen er rotfestet i Oppdal-samfunnet, og 
hvordan disse spørsmålene har utviklet seg. Dette langsiktige blikket oppfattes jeg styrker kapitlets datagrunnlag.

Dette innebærer samtidig at jeg har vært en aktør som er medansvarlig i de valg Oppdal-samfunnet har gjort. Likevel er mine roller under masterplanarbeidet og som ansvarlig for feltkurs i naturressursforvaltning såpass ulike at verdigrunnlaget i de to prosessene kan hevdes å «utligne» hverandre. Under feltarbeidet var oppgaven å sette et kritisk lys på maktforholda i Oppdal-samfunnet. Dette medførte også et kritisk lys til egen deltakelse i masterplanprosessen.

Valg av metode og kilder er alltid influert av forskerens perspektiv. En forsker vil alltid være posisjonert. Kapitlets metodedel beskriver nøye innsamlingen av kapitlets datagrunnlag. Denne siste delen av metodebeskrivelsen legger vekt på å gi innblikk i bakgrunnen for denne datainnsamlingen. Slik sett kan leseren reflektere over mulige koblinger mellom forskerens posisjonering og de valg som ligger til grunn for kapitlets innhold. Refleksjon over forskerens posisjonering oppfattes som mer ærlig enn det forfatteren oppfatter som et urealistisk krav på full objektivitet. Et slikt ståsted, som står i opposisjon til et positivistisk standpunkt, er også i overensstemmelse med en politisk økologisk tradisjon (Benjaminsen \& Svarstad, 2017; Robbins, 2020). Samtidig har jeg hele tiden vært tvunget til å reflektere over betydningen av egne posisjoner. En kan her også trekke paralleller til det som kalles «first person action research» (Marshall, 2016).

\section{Politisk økologi og forståelse av miljøkonflikter}

Oppdal-samfunnet formes gjennom maktkamper mellom ulike interesser og perspektiv, både på et materielt og ikke minst diskursivt plan. Dette er et perspektiv som bygger på et politisk økologisk perspektiv, og som har gitt inspirasjon til dette kapitlet (Benjaminsen \& Svarstad, 2017; Robbins, 2020). I starten av kapitlet ble det drøftet hvilke valg Oppdalsamfunnet står overfor i fremtiden. Hvordan dette spørsmålet besvares er viktig, men samtidig er det feil å se på Oppdal som et enhetlig samfunn. Selv ikke på Oppdal er alle i «samme båt». Samtidig vil mange aktører være gjensidig avhengige av hverandre, men også avhengige av eksterne 
forhold utenfor Oppdal. Det vil være motstridende interesser og meninger om hvordan goder og kostnader skal fordeles mellom ulike aktører og interessenter, og helt klart være ulike visjoner om hvordan Oppdal skal utvikle seg i fremtiden. Dette gjelder også forvaltning av arealressurser og miljø. Selv om «miljøhensyn» av mange blir sett på som noe grunnleggende positivt, er politikkområdet ikke fritatt fra normale interessemotsetninger. Også beslutninger innen dette området vil få konsekvenser for involverte aktører. For eksempel vil verning av et naturareal kunne redusere inntektene til grunneiere som ellers kunne solgt hyttetomter i det samme området.

Politisk økologi (Benjaminsen \& Svarstad, 2017; Robbins, 2020) som fagfelt har som standpunkt at miljø- og ressursforvaltning nettopp er konflikter mellom ulike aktører og interesser, og at dette som oftest fører til vinnere og tapere i kampen om goder og innflytelse. Dette er konflikter som går på den materielle fordelingen, men omfatter også konflikter på et diskursivt nivå, dvs. innen hvilke rammer ulike tema skal forstås. Hva som oppfattes som fakta, rett og galt om et tema vil være viktig også for hvilke interesser som vinner frem i en bestemt sak. Politisk økologiske analyser vil ofte søke å identifisere hvilke diskurser som har utkrystallisert seg i forhold til det konfliktområdet som analyseres (Benjaminsen \& Svarstad, 2017; Robbins, 2020). I noen sammenhenger vil det være en dominerende eller hegemonisk diskurs, mens det i andre situasjoner vil herske en diskursorden av flere diskurser med ulik gjennomslagskraft. Ofte vil det også eksistere diskurskoalisjoner (Hajer, 1995) som underbygger og støtter seg på en gitt diskurs. I dette kapitlet søkes nettopp å identifisere diskurser og diskurskoalisjoner rundt Oppdal-samfunnets fremtid og hvordan en forholder seg til arealressursene i nærområdet.

Hvem som vinner eller taper i slike konflikter gjør også selvsagt makt og maktforhold til en avgjørende faktor det vil være viktig å avdekke. Makt og maktressurser vil her dreie seg om en rekke forskjellige ting som finansielle ressurser, eiendomsrettigheter og muligheter til å påvirke politiske beslutningsprosesser. Makt i et politisk økologisk perspektiv kan både være det som faller innenfor aktørorienterte perspektiv på makt (Engelstad, 1999) og mer diskursive maktperspektiv (jf. Flyvbjerg, 1998; Foucault, 2008), samt strukturell makt i et mer marxistisk perspektiv. 
Det er da også et slikt kombinert maktbegrep Svarstad et al. (2018) fremhever.

Politisk økologiske analyser vektlegger også hvordan ulike geografiske nivå griper inn i hverandre, samt at en må se dagens situasjon i et historisk perspektiv. Dette betyr at nasjonale diskurser vil kunne få regionale og lokale konsekvenser, jamfør eksempelvis nasjonale diskurser om naturvern, og lokale diskurser vil påvirkes av regionale og nasjonale forhold. Politisk økologi vektlegger nettopp samspillet mellom ulike geografiske nivåer, og at konflikter ikke kan forstås ut fra bare å betrakte ett geografisk nivå (Benjaminsen \& Svarstad, 2017). Det er eksempelvis vanskelig å tenke seg hyttekommunen Oppdal uten å sette den inn i et regionalt perspektiv hvor Oppdal kan betraktes som en «hytteforstad» til Trondheim og andre større befolkningskonsentrasjoner i regionen. Hytteundersøkelsen (Nasjonalparken Næringshage AS, 2015) viser at majoriteten av hyttebefolkningen på Oppdal er bosatt i større regionale befolkningskonsentrasjoner (ikke minst Trondheims-området med $55 \%$ ). Uten en regionalt basert etterspørsel ville utviklingen på Oppdal ikke skjedd. Likens vil utviklingen innen jordbruket være sterkt påvirket av utviklingen i økonomien generelt, og helt spesifikt av den nasjonale jordbrukspolitikken. Videre vil også rettighetssituasjonen og juridiske eiendomsforhold spille inn. Med tanke på dagens eiendomsstruktur på Oppdal med eiendomsregimer og rettigheter i utmarka, er også historien viktig. I etterkant av innføringen av den første jordskifteloven i $1859^{1}$ skjedde det en endring $\mathrm{i}$ eiendomsstrukturen hvor teigblandingen innen landbruket ble redusert. På Oppdal resulterte det $\mathrm{i}$ at gårdene ble striper av land som strakk seg fra lavlandet og opp mot fjellet. Høyfjellet ble bevart som fellesressurs, mens områdene mellom ca. 700 moh. og 1000 moh. ble privat eiendom som samtidig fungerte som en felles beiteressurs (Aalbu, 2019). For å forstå dagens situasjon må en forstå hvordan rettighetssituasjonen har utviklet seg i en dynamisk prosess over tid. Dagens situasjon vil derfor alltid være i en brytningsfase mellom dagens forhold og strukturer fra tidligere tider.

Analyser med et politisk økologisk perspektiv viser hvordan kompleksiteten i samspillet mellom de forhold som er nevnt ovenfor kan brukes

$1 \quad$ Lov om Jords og Skovs Udskiftning af Fællesskab av 12. oktober 1857. 
til å avdekke konflikter og maktforhold i miljø- og ressursforvaltningen. Analyser som trekker på både samfunns- og naturvitenskaper, samt ulike typer av kunnskap - både vitenskapelig, men også erfaringsbasert kunnskap. I dette kapitlet bruker vi et slikt perspektiv for å se nærmere på hvordan interessekonflikter på Oppdal påvirker på de rådene diskursene om hvordan Oppdal skal forvalte sine utmarksressurser.

Vi har ovenfor beskrevet bakgrunnen for kapitlet, samt dets metodiske utgangspunkt og teoretiske grunnlag. Basert på analysene av situasjonen er det identifisert fire diskurser knyttet til hytter og arealvern i Oppdal-samfunnet. Videre i dette kapitlet vil vi ta for oss hver enkelt diskurs og grunnlaget for disse, for så å trekke noen konklusjoner til slutt om de utfordringer Oppdal står ovenfor.

\section{Oppdal: Destinasjonsutvikling med fokus på hytteutbygging}

Merkevaren Oppdal har over lang tid hatt «Oppdal så klart» som slagord og «Oppdalssola» som logo. Under arbeidet med masterplanen for Oppdal hevdet de som jobbet profesjonelt med merkevareutvikling at denne profilen burde byttes ut. Dette møtte stor motstand fra «oppdalinger» i prosjektgruppen, som syntes å ha sterk identitet til denne merkevareprofilen. Profilen har sine røtter helt tilbake til 1950-tallet, men kom først i bruk på 1970-tallet, da blant annet av Oppdal Reiselivslag (personlig kommunikasjon, Svein Schønheyder, 4. januar 2020).

Kritikken gikk dels på at profilen var lite tidsriktig, noe som kanskje ikke nødvendigvis er et så vektig argument. Et mer slagkraftig argument er derimot at det ikke er sikkert at «Oppdal så klart» er så klart lenger. Opprinnelig var Oppdal kjent som en «alpin» destinasjon, men har etter hvert møtt hard konkurranse. Åre har blitt den mer opplagte alpindestinasjonen også for folk i Midt-Norge, med 1,1 millioner gjestedøgn, hvorav 62 prosent i årets første måneder (Jämtland Härjedalen Turism, 2020). Diskusjonen rundt slagord og logo for Oppdal illustrerer den selvforståelsen en har hatt på Oppdal, og den realitetsvurdering en var nødt til å ta når en begynte å se hva slags destinasjon stedet faktisk var. 


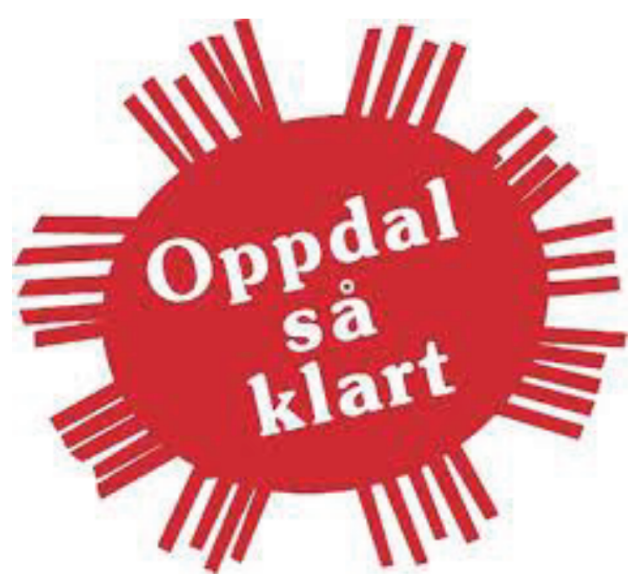

Figur 1. «Oppdal så klart» og Oppdalssola som rotfestet logo og brand for Oppdal som destinasjon. Copyright: Valdis Schønheyder, gjengitt med tillatelse.

Dette har medført at Oppdal, selv om merkevaren har lang tradisjon, likevel har måttet tenke nytt om hva som er Oppdals styrke som reiselivsdestinasjon. Under masterplanprosessen pekte Enger et al. (2013) sin ringvirkningsanalyse på at majoriteten av gjestedøgn var på hytter (ca. 75 prosent). Videre var utredningen fra det velrenommerte konsulentselskapet International Alpine Design (2013) svært skeptisk til kvaliteten på eksisterende alpinanlegg. Denne vridningen mot andre attraksjoner fremkommer også i hvordan vedlikehold av langrennsløyper ble vektlagt i forhold til fellesgodefinansiering (Sandnes et al., 2013). Alt dette pekte i retning av å fortsette en satsing på hyttebygging. Det kan ellers opplyses at Oppdal kommune i 2019 hadde 3865 hytter (SSB, 2020).

Sterke aktører i Oppdal-samfunnet ønsker videre utvikling av hyttebyggingen. Eksempelvis har det foregått en storstilt utbygging av hytter med middels til høy standard på Oppdalstoppen. Sentrale aktører som har vært involvert i dette er blant annet forretningsmannen Bjørn Ove Ansnes $^{2}$ og ulike grunneiere som ønsker å utvikle sine eiendommer. I masterplanprosessen ble det bedt om innspill til arealforvaltning, og flere ønsket å promotere egne utbyggingsplaner. Et slikt forslag var et

2 Bjørn Ove Ansnes er en sentral næringsaktør på Oppdal. Han er daglig leder for Oppdalstoppen. Videre daglig leder eller styreleder for en rekke andre selskap av betydning for Oppdal (se https://www.proff.no/rolle/bj\%C3\%B8rn-ove-ansnes/oppdal/70876/). 
utbyggingsprosjekt vest av dagens alpinbakke i Vangslia. Dette forslaget ble levert som kart og planforslag direkte til arealplangruppa under masterplanprosessen. Slik sett var det både under masterplanarbeidet, og i ettertid, et stort trykk mot realisering av eiendomsprosjekt.

Også handelsstanden har fordeler av en hyttesektor som gir mer handel på Oppdal enn steder med tilsvarende størrelse ellers ville hatt. Arbeidsplasser innen varehandel, sysselsetting og handel utgjør 32 prosent av arbeidsstyrken (SSB, 2020). Dette er høyt, og en kan tenke seg at reiselivssektoren knyttet til gjennomgangstrafikk og hyttebefolkningen bidrar sterkt til dette. Under arbeidet med masterplanen var det mye snakk om parkeringsplasser i sentrum. Dette skyldes nok ikke bare hyttebefolkningen, men også Oppdals rolle som «vegknutepunkt».

I masterplanprosessen ble det formulert et mål om 100-110 nye hytter i året (Asplan Viak, 2013). At næringsinteressene sto sterkt i en slik prosess er ikke overraskende, da Oppdal Næringsforening sto som oppdragsgiver og prosjekteier. I styringsgruppen var også sterke aktører som Oppdalsbanken og Sparebanken Midt-Norge representert, sammen med blant annet Oppdal kommune (Asplan Viak, 2013). Det gjorde at prosessen hadde et tungt økonomisk fokus. Selv om det var åpne folkemøter og arbeidsseminar med en bred deltagelse, var det nærmest per definisjon et økonomisk hegemoni i en slik «destinasjonsutviklingsprosess». Gitt bildet av eksisterende situasjon (Enger et al., 2013), var det også nærliggende å sikte mot fortsatt vekst i antall hytteovernattinger. Altså, en satset på mer av det som alt var den dominerende trenden. Tankene gikk mer i å videreutvikle dagens utviklingsmønster enn å styre mot et trendbrudd (Asplan Viak, 2013). For å ytterligere underbygge vektleggingen av hyttefolket, brukte en i diskusjonene begrepet «hytteoppdalinger» for å nærmest gjøre dem til en del av lokalbefolkning.

Det er liten grunn til å tvile på at det frem til i dag har vært relativ stor forståelse for turistnæringens betydning i Oppdal-samfunnet. Som del av feltarbeidet under ekskursjon til Oppdal gjorde studentene en spørreundersøkelse blant folk i Oppdal sentrum. Majoriteten av de spurte oppfattet at turismesektoren hadde stor betydning for Oppdal, og at den gjorde Oppdal mer «interessant». Majoriteten var også helt eller delvis uenig i at dette hadde negative effekter på natur og jordbruk. 


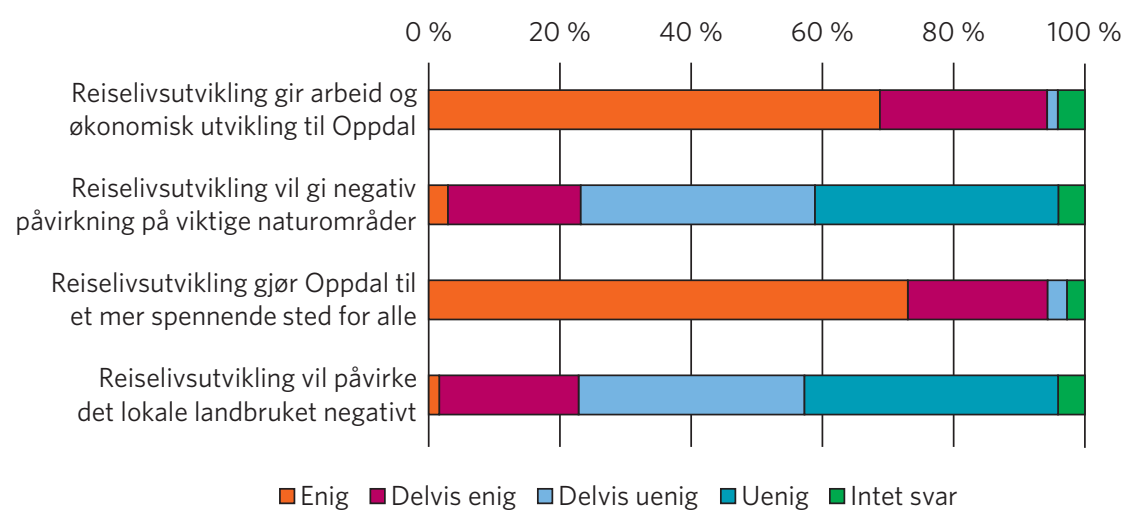

Figur 2. Holdninger til turistnæringen på Oppdal. Uformell undersøkelse september 2017. N = 70.

Majoriteten var også imot at en skulle søke å begrense reiselivsutviklingen på Oppdal. Hele 77 prosent svarte nei på spørsmålet: «Synes du Oppdal kommune bør gjennomføre tiltak som senker reiselivsutviklingen på Oppdal?» Det er et entydig svar på at en ønsket en fortsatt satsing fremover.

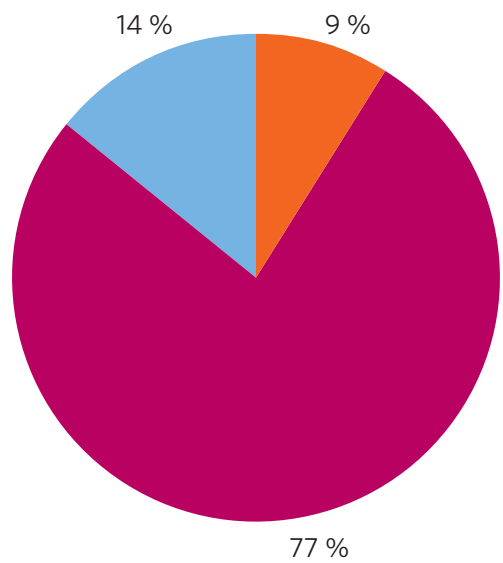

$\square$ Ja $\square$ Nei $\square$ Intet svar

Figur 3. Holdningen til spørsmålet: «Synes du Oppdal kommune bør gjennomføre tiltak som senker reiselivsutviklingen på Oppdal?» $\mathrm{N}=70$.

Denne undersøkelsen er basert på et såkalt convenience sample, samt har et relativt begrenset antall respondenter $(\mathrm{N}=70)$. Hovedtendensen er likevel såpass sterk at det nok gir et riktig bilde av holdningene $\mathrm{i}$ Oppdal-samfunnet totalt sett. Tendensen stemmer også overens med hva som er blitt kommunisert fra våre nøkkelinformanter. Siden hytter er den 
dominerende overnattingsform for tilreisende på Oppdal (Enger et al., 2013), vil oppfatninger om reiselivet generelt også i stor grad omfatte hytteturismen.

Oppsummert kan en derfor snakke om en relativt dominerende diskurs rundt hytteturisme på Oppdal. Sterke aktører innen eiendomsbransjen, banker, næringsforeninger og handelsstanden, som jo også var sterke interessenter bak masterplanprosessen, deler en oppfatning av at hytteutvikling er viktig for Oppdal og skaper mange arbeidsplasser. Også grunneiere som ønsker å selge hyttetomter må regnes med her. Denne aktørkoalisjonen har hatt aksept blant flertallet av lokalbefolkningen og kommunen, men denne har kanskje blitt noe mer betinget utenfor kjernen av diskurskoalisjonen, noe vi kommer tilbake til senere. Om en imidlertid ser på rene økonomiske tall (Enger et al., 2013), er hyttenæringen på en måte en stor «økonomisk maskin» som Oppdalsamfunnet har gjort seg avhengig av.

\section{Jordbruksbygda Oppdal og dens arealbehov}

En alternativ diskurs kan spores innen landbruket. Tradisjonelt har Oppdal vært en jordbrukskommune, og den er en av Norges største sauekommuner med rundt 48 ooo sauer på beite om sommeren. Videre er det også melkeproduksjon, og blant annet dyrking av mandelpotet. I 2019 var det 220 aktive gårdbrukere i Oppdal, noe som inkluderer 50 melkeprodusenter, 30 som har kyr uten melkeproduksjon, 124 sauegårder, 2 som driver med geit samt 15 pelsdyrfarmer. Slik sett er jordbruk en viktig del av Oppdal-samfunnet (Aalbu, 2019).

Landbruket er også interessant fordi det er en mangfoldig sektor hvor ulike aktører har motstridende interesser. I forhold til «hyttediskursen» drøftet ovenfor er det mange grunneiere som tjener på å selge hyttetomter. Det kan være grunneiere som ikke lenger er aktive drivere, eller driver innen deler av næringen som ikke trenger alle sine utmarksressurser til beite og annen landbruksrelatert virksomhet. Eksempelvis kan salg av hytter finansiere utbygging av ulike typer driftsbygninger.

På den andre siden har en de som ønsker å opprettholde tradisjonelt utmarksbeite. Et bredt spekter av landbruksorganisasjoner på Oppdal, 
dvs. Oppdal bonde- og småbrukarlag, Oppdal bondelag, Produsentlaget, Lønset bondelag og Oppdal sau og geit, stiller seg kritisk til en næringsutvikling basert på stadig forbruk av arealressurser. De oppfatter dette som lite bærekraftig (jf. innspill til Strategisk noringsplan $i$ Oppdal kommune, datert 01.11.2017). Deres uttalelse kan sees som et forsøk på å begrense hytteutbyggingen $\mathrm{i}$ arealer av stor betydning for beitenæringene. Områder attraktive for hyttebygging utgjør også områder spesielt godt egnet som beiteressurser. Dette er områder i høyfjellsskogen opp mot skoggrensen, dvs. over 600-700 meter og oppover til skoggrensen. Dette gjelder i stor grad områdene mot Trollheimen nord for Oppdal og riksveg 70, og vest av E6 nordover fra Oppdal.

Som en kan se av figur 4 er det stort overlapp mellom hva som er områder svært godt egnet til beite for sau og hva som utgjør de viktigste hytteområdene. Dette kan skape en konflikt om bruken av arealene, hvor hytteutbygging forbruker beitearealer som en ikke-fornybar ressurs.

Tamreindrifta i Trollheimen er et ytterligere kompliserende trekk i konflikten mellom beitenæringene og hyttesegmentet. For reinnæringen er det ikke direkte arealbeslaget fra hyttene som sådan som er det største problemet, men den fritidstrafikken hyttefolket skaper (Oppdalingen, 2016).

I diskusjonen om utmarksbeite ligger det også et større spørsmål om hva for slags landbruk vi skal ha. I feltkurset i naturressursforvaltning var det lagt inn et foredrag av en engasjert sauebonde ${ }^{3}$ som påpekte spenningsforholdet rundt modernisering av sauenæringa med økt bruk av innmarksbeite og kraftfor på bekostning av bruk av utmarksbeite. Litt spisst kan en her peke på en konflikt mellom et delvis økologisk landbruk versus et mer industrielt landbruk. Vår informant var her av den oppfatning at i et «bærekraftperspektiv» ville det være bedre å bruke utmarksbeite fremfor kjøpte innsatsfaktorer.

Konflikten rundt hytter er mer komplisert enn bare rene arealbeslag. En har rett til å ha beitedyr på beite mellom hyttene, men oppsetting av gjerder kan medføre problemer. For elektriske gjerder som blir slått av når hyttefolkene ikke er til stede, har det vært tilfeller der sau har satt seg fast i gjerdene og omkommet på en tragisk måte (Aalbu, 2019). 

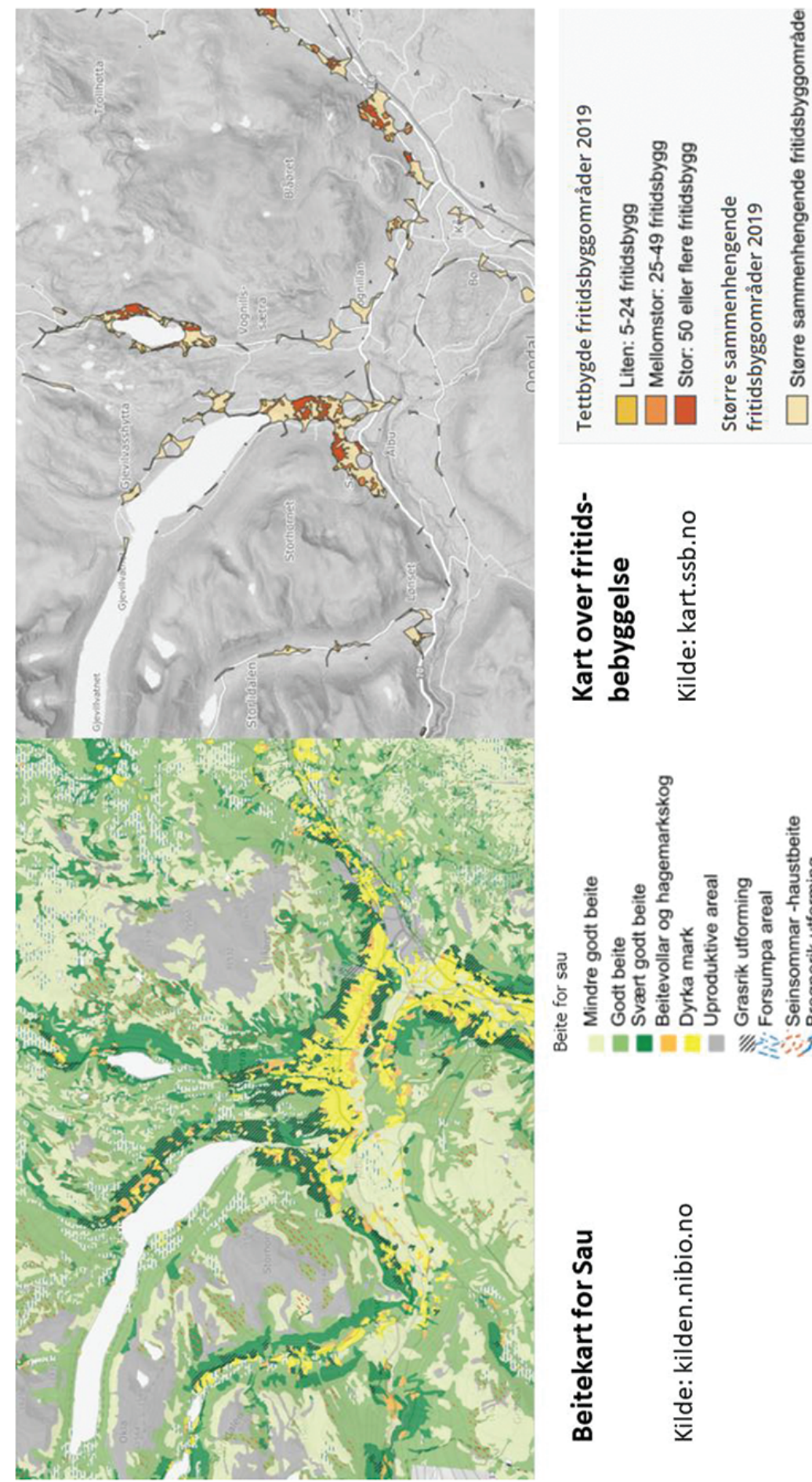

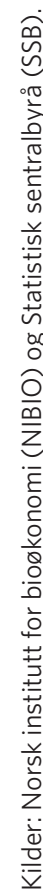
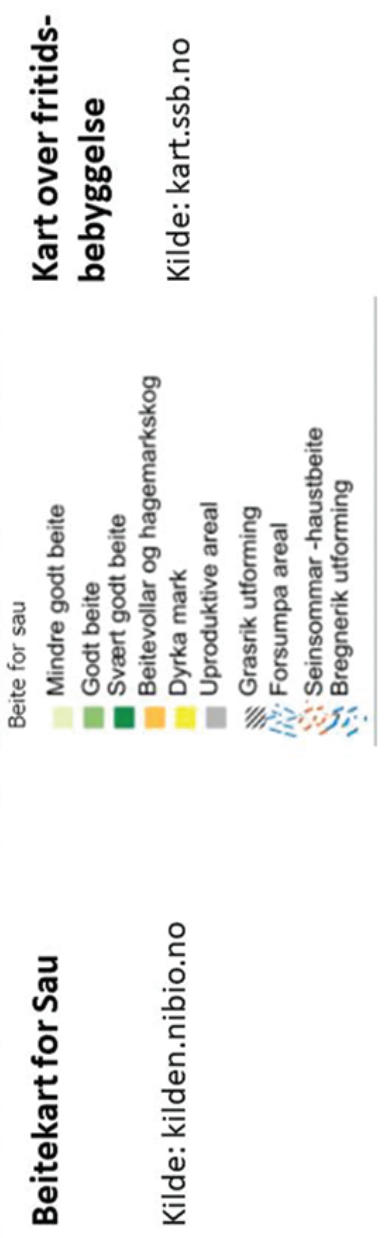

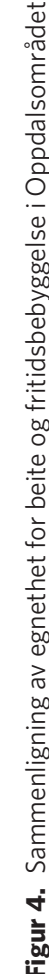




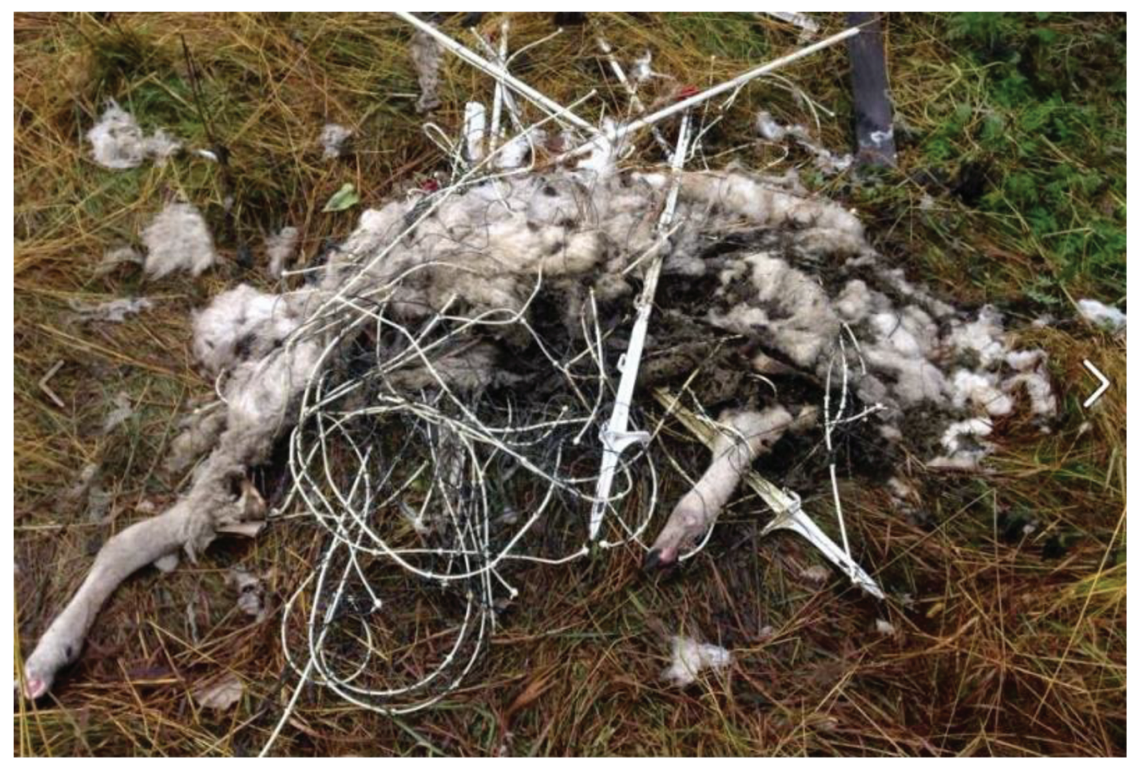

Figur 5. Sau omkommet etter å ha satt seg fast i strømgjerde (foto: Anita Schive Bjerkaas, gjengitt med tillatelse).

I møtet mellom sauebønder og hytteeiere er det også kulturkonflikter der sauebøndene oppfatter hytteeierne som uten respekt for bøndenes beiterettigheter, mens hytteeierne ser på beite som noe som ødelegger hytteopplevelsen både med lyd fra bjeller og sauebæsj på terrasser. ${ }^{4}$ Som illustrasjon på denne situasjonen fortalte vår informant en historie om en sauebonde som var blitt oppringt av en hytteeier som lurte på om det ikke var mulig å slå av sauebjellene om natta. ${ }^{5}$ Om dette er en sann historie eller en vandrehistorie vites ikke, men illustrerer likevel en stemning mellom disse partene. Historien peker på den manglende forståelsen enkelte sauebønder mener hytteeierne har for landbruket. Et slikt bilde ble også bekreftet av kommunens fagleder for kultur, landbruk og miljø (Aalbu, 2019).

Jordbruket i Oppdal er mer enn bare sauenæringen - det inkluderer også storfehold, både til melkeproduksjon og kjøtt, og produksjon av blant annet mandelpoteter. Slik sett har kommunen et mangfoldig landbruk hvor ikke alt er i konflikt med «hyttenæringen». Imidlertid kan en si

$\begin{array}{ll}4 & \text { Kilder: Ole Krokan 09.11.2019; Aalbu, } 2019 \\ 5 & \text { Muntlig presentasjon: Ola Krokan 09.11.2019 }\end{array}$ 
at det eksisterer en diskurs som hevder at den tradisjonelle utmarksbruken er truet av fritidsbruk og eiendomsutvikling i utmarka. I denne diskursen presenteres et bilde av at langsiktig, økologisk og bærekraftig bruk som står opp mot kortsiktige og ikke bærekraftige «pengeinteresser».

\section{Oppdal som natur}

Oppdal er en fjellbygd omgitt av natur og fjell. Kommunen er omkranset av store naturvernområder med Dovre-Sunndalsfjella nasjonalpark i syd og Trollheimen landskapsvernområde i nord/nordvest. Til sammen er 52 prosent av Oppdal kommune verneområder (Aalbu, 2019). Også fra naturvernhold har det vært rettet kritikk mot hyttebygging. Dette er nok en diskurs som er like mye nasjonal som knyttet til Oppdal. Oppdal blir her bare et eksempel på en generell utvikling hvor en er kritisk til hyttebyggingen i utmarka. Dette er en kritikk som rettes fra flere hold. I et oppslag på Naturvernforbundets hjemmeside sier Tor Bjarne Christensen (2019) at «Nedbygging av arealer og arealendringer er, sammen med klimaendringene, de største truslene mot natur og naturmangfold». Under overskriften «Hyttebygging truer naturen i Norge» mener Naturvernforbundet at dagens utvikling ikke kan fortsette. Også andre samfunnsaktører fremhever liknende synspunkter. Ygranes (2020) skriver i Intersport sin nettavis Lidenskap for tur at «Hytteutbygging truer norsk natur: Nordmenns hytteambisjoner fører til tapt naturmangfold» (artikkelens overskrift). Også fra forskerhold rettes det kritikk mot denne utviklingen. Carlo Aall (2017) skriver en artikkel i Syn og segn med tittelen «Hyttelivet er ikkje lenger berekraftig». Her dreier det seg ikke bare om forbruk av natur, men også energi- og ressursbruk generelt. Aall ved Vestlandsforskning påpeker imidlertid at hytteutbygging ikke nødvendigvis alltid vil være problematisk, men at hva slags hytter vi har og hvordan de brukes også er viktig. Seniorforsker ved Norsk institutt for naturforskning (NINA) Bjørn Petter Kaltenborn (2018) er enda mer kritisk, og skrev en kronikk i Aftenposten med overskriften «Hyttebyggingen har gått over alle støvleskaft».

Som vi ser, eksisterer det en kritisk diskurs rundt natur- og miljøbelastningen fra hyttebygging på nasjonalt nivå. Spørsmålet er om denne 
diskursen også er representert på det lokale nivået i Oppdal? Tor Olav Naalsund (2018), som representerer Miljøpartiet de Grønne i Oppdal og Rennebu, kommer med lignende kritiske uttalelser. Også Harald Jære (2018) fra Lønset, Oppdal, uttrykker i en artikkel i Adresseavisen at «Tiden er overmoden for å ta en vurdering om videre hyttebygging og utmarksturisme generelt». Jære argumenterer riktignok med både hensyn til naturvern og beitenæringene, slik at her vil det også være sammenfallende synspunkter mellom kritikk av «hyttekomplekset» fra en jordbruksbasert synsvinkel og en kritikk rotfestet i et natur- og miljøvernstandpunkt. Samme type kritikk kan en finne i Toftaker \& Toftaker (2015) sitt innspill til arealplan for Oppdal. De begrunner innspillet i Naturvernloven, og argumenterer ut fra konsekvenser for spesifikke arter.

En kan derfor hevde at det finnes en naturvernbasert nasjonal diskusjon som er kritisk til dagens hyttebygging, og at denne også er representert i Oppdal-samfunnet. Dette er imidlertid en nasjonal diskurs, men med lokal representasjon og lokale konsekvenser. Dette viser også tydelig viktigheten av politisk økologi sin vektlegging av at miljøkonflikter bare kan analyseres om en kobler ulike geografiske nivå (lokalt, regionalt og nasjonalt). Et utelukkende lokalt perspektiv vil medføre at en ikke ser kompleksiteten i areal- og ressurskonfliktene. Interessant er også at denne diskursen får samme «front» som den jordbruksbaserte diskursen, selv om de to diskursene er rotfestet i ulike diskursallianser og til dels bruker ulike argumenter. Forskjellen i argumenter og allianser er grunnen til at jeg her har valgt å se dette som to uavhengige diskurser.

\section{Utfordringer for Oppdal-samfunnet}

Som nevnt ovenfor har Oppdal-samfunnet hatt en relativt positiv utvikling sammenlignet med andre distriktssamfunn i Midt-Norge. Dette kan dels skyldes strukturelle forhold, som den regionale arbeidsdelingen og spesielt gunstige lokale lokaliseringsfaktorer, eller at en har hatt et vellykket valg av lokal utviklingsstrategi.

I kapitlets innledning ble viktige trekk ved Oppdal og næringslivet beskrevet. Disse trekkene har også vært med på å forme politikk og strategivalg 
i Oppdal-samfunnet. Eksempelvis har Oppdal sentrums rolle som vegkryss vært viktig i debattene rundt sentrumsutvikling. Et eksempel er ny E6 gjennom sentrum. Istedenfor å lage en omkjøringsveg ble et kort stykke av Norges hovedveg fra syd til nord flyttet inne i sentrum, noe som fikk daværende samferdselsminister Kjetil Solvik Olsen til å riste på hodet (Adresseavisen, 2014). Et annet eksempel på dette er diskusjonene rundt parkeringsplasser, der det har vært kraftig trykk for å sikre nok parkeringsplasser i Oppdal sentrum. En regneøvelse som ble gjort i debatten rundt utformingen av Oppdal sentrum var å anslå verdien av en parkeringsplass gjennom å dele omsetningen til varehandelen i sentrum på antall parkeringsplasser (personlig kommunikasjon, Tina Selbekk, sept. 2018). Disse utslagene i arealplanleggingen og debatten rundt denne viser hvor stor betydning rollen som vegkryss og stoppested for gjennomgangstrafikken har vært for handelsstanden. En kan selvsagt være kritisk til slike utspill og beslutninger, men samtidig utgjør handelsnæringen en viktig kilde til arbeidsplasser og sysselsetting for Oppdal-samfunnet. En strategisk utfordring er da hvilke verdivalg en gjør med tanke på den fremtidige utviklingen. Hva vil en med sentrum, og hvordan skal dette oppnås?

Et annet aspekt er reiselivsnæringen og hvordan utvikle denne videre. Reiselivs- og besøksnæringen har over lengre tid vært viktig for Oppdal-samfunnet, men med et varierende fokus. Som Asplan Viak (2013) viser har hytter blitt den helt dominerende overnattingsformen. Hyttebyggingen på Oppdal har en rekke ringvirkninger, også til andre deler av økonomien - som byggebransjen og handelsnæringen. Samtidig kan arealer til hytteutbygging betegnes som en ikke-fornybar ressurs. Hensyn til naturvern og bærekraftig utvikling stiller spørsmål ved en videre utvikling av denne sektoren. Et av de kanskje viktigste strategiske spørsmål for Oppdal-samfunnets veg videre, er derfor hvordan en i fremtiden skal forholde seg til denne sektoren. I tillegg til den dominerende hyttesektoren har Oppdal også forsøkt å markere seg som et sentrum for større arrangement. Oppdal har flere ganger huset Landsskytterstevnet, samt den årlige «Fjell og fårikål-festivalen». ${ }^{6}$

Selv om handel og besøksnæring er viktige for Oppdal, finnes også andre næringer og utfordringer. Tradisjonelt har fjellbygda Oppdal

6 Se https://www.fjellogfaarikaalfestivalen.no/ 
vært en jordbruksbygd hvor primærnæringene har stått sterkt. I dag er bygda en av Norges største sauekommuner, men også andre deler av jordbruket er viktig. Samtidig er utviklingen i landbruket preget av strukturrasjonalisering hvor det blir stadig færre drivere. Mange tidligere aktive gårdsbruk disponeres nå av en «eiendomsbesitter» som ikke selv driver gården. Strukturendringene i jordbruket medfører samtidig mer bruk av innsatsfaktorer som kraftfor, og mindre bruk av utmarksbeite. Dette kan skape nye utfordringer og motsetninger internt mellom ulike grunneiere og mellom landbruket og andre næringer.

Et siste aspekt er naturvern og bærekraftspørsmål. At store deler av Oppdal er vernet kan på ene siden sees som en bremsekloss for fremtidig næringsutvikling, men en skal heller ikke se bort fra betydningen av det kvalitetsstemplet som ligger i en vernestatus. Her er en igjen tilbake til strategivalg og avveininger mellom hva som skal utvikles for fremtiden.

I tillegg til de utfordringer som ligger ovenfor er det også en rekke andre næringer som bidrar til Oppdal-samfunnets økonomi og utvikling. En av de viktigste er skiferindustrien, som blant annet har større skiferbrudd i Drivdalen mot Dovre samt industribedrifter som kutter til råvaren i Oppdal sentrum. Skifer bidrar også som en kulturell markør for Oppdal-samfunnet, for eksempel har bygdas største hotell, Skifer Hotell, en markant skiferfasade. Også skiferindustriens rolle kan problematiseres, dels som kilde for arbeidsplasser og kulturell markør, men også som en industri med miljømessige konsekvenser som lager markante sår i landskapet (se også Oppdal Sten AS sin hjemmeside (http://www. oppdalsten.no/); Røskaft, 2009).

Samlet sett stiller disse næringene og utfordringene Oppdal-samfunnet fremfor en rekke valg og prioriteringer som må gjøres for fremtiden. Hva for fremtid ønsker en seg for Oppdal? Hvilke interesser skal gis prioritet? Det er sannsynligvis delte oppfatninger om hvilken veg en skal gå.

\section{Mot en vinn-vinn-diskurs om hyttebygging?}

Selv om det har vært kritiske røster, så har næringsinteressene frem til nå hatt mest gjennomslag. Bak hytteinteressene står mektige næringsinteresser som også representerer det økonomiske grunnlaget 
for Oppdal-samfunnet. Imidlertid er det som vist kommet kritikk av bærekraften til denne næringen. Natur og beite trues, hevdes det, og å bygge 100-110 hytter i året vil være å bruke arealene som en ikkefornybar ressurs som sakte, men sikkert brukes opp. Dette gir en bekymring rundt hyttenæringens utfordringer som kobles mot en erkjennelse av dens økonomiske betydning.

Utfordringer mot den dominante økonomiske modellen har kommet fra deler av landbruket og fra miljøhold. Etter hvert har lokale aktører på Oppdal søkt å bygge alternativer som tar hensyn til miljø- og landbruksinteressene samtidig som en bevarer den økonomiske motoren som ligger i hyttenæringen. Aktører bak dette er til dels Oppdal kommune, samt lokale utviklingsaktører slik som Nasjonalparken næringshage (Nasjonalparken Næringshage, Trøndelag fylkeskommune og Pir II 2018). Næringshagen er et av mange privat-offentlige utviklingsselskap som finnes i Distrikts-Norge? I tillegg er det også enkelte entreprenører og eiendomsutviklere som har engasjert seg i det en kaller «grønn hytteutbygging», uten at det er gitt noen enhetlig beskrivelse av hva det innebærer. To av disse presenterte sine prosjekter under NTNU sitt feltkurs i 2018 og 2019. På et overordnet nivå kan en betrakte dette som en diskurs der en forsøker å tilfredsstille flere motstridende interesser, eller i det minste lage et kompromiss som er akseptabelt for flere parter.

En kan betegne dette som en "vinn-vinn-diskurs om hyttebygging» hvor en søker å etablere grønn hyttebygging som et bærekraftig alternativ til den etablerte hyttebyggingen. Dette kan sees som et forsøk på å finne en måte hvor en kan videreutvikle dagens hyttebygging på en måte som opphever motsetningen mellom de tre tidligere diskursene omtalt i dette kapitlet. I en positiv fortolkning kan dette sees som en måte å finne et alternativ alle faktisk er tjent med. Noe mer konspiratorisk, kan dette sees som et retorisk grep for å nøytralisere kritikk. Benjaminsen og Svarstad (2017) har identifisert flere slike «vinn-vinn-diskurser» innen tema som naturvern, bioprospektering og kvotehandel om utslipp av klimagasser. Imidlertid er Benjaminsen og Svarstad i disse eksemplene kritiske til påstanden om vinn-vinn. De hevder at slike vinn-vinn-diskurser i stor grad er retoriske

7 Se også hjemmesiden til Nasjonalparken Næringshage: https://www.nasjonalparkhagen.no/ 
og skjeve beskrivelser av hva som «egentlig skjer». For hyttedebatten på Oppdal kan en slik vinn-vinn-diskurs beskyldes for å være et forsøk på «grønnvasking» av hyttenæringen. Grønnvasking er et begrep for hvordan eksempelvis næringslivet og offentlige aktører forholder seg til miljøkritikk ved å gi seg ut for å være mer miljøvennlig og bærekraftig enn det de egentlig er (se f.eks. Netto et al., 2020; Yu et al., 2020). Så kan en stille spørsmålet om diskurser om grønn hyttebygging er grønnvasking, bærekraftig utvikling, eller - kanskje som oftest - noe midt imellom.

Oppdal kommune var aktiv medspiller i masterplanprosessen. Imidlertid synes det som Oppdal kommune nå har satt på bremsene noe. I eksisterende arealplan er det satt av hyttetomter for fortsatt utbygging av 100 hytter i året opp mot 15 år inn i fremtiden. Kommunen har derfor satt stopp for å regulere inn flere områder til fritidsformål, begrunnet med at en har de tomtene en trenger. I kommunens reguleringer ligger det også inne krav om at maks 40 prosent av tomta kan gjerdes inn, noe som skal gjøre det mulig å beite også inne i hyttefelta (Aalbu, 2019). Slike bestemmelser og begrensinger kan ikke sees på som «grønn hytteutbygging», men som forsøk på kompromiss i retning av en vinn-vinn-strategi. Videre vil nok dette ha liten betydning i praksis, da det allerede finnes en stor reserve av arealplansikrede hyttetomter (Aalbu, 2019).

Den lokale aktøren som klarest har frontet en alternativ hyttestrategi er Nasjonalparken Næringshage, blant annet gjennom prosjektet «Grønn Fjellhageby» (Nasjonalparken Næringshage, Trøndelag fylkeskommune og Pir II 2018). Ut av dette kom et notat som beskriver konsepter for ulike typer hytteutbygging basert på en sonering av ulike konsept, fra det man kaller «urban-hytter» i tettstedsnære områder til «naturhytter» som har lav/enkel standard og som er plassert ute i naturprega områder. Utforming av de ulike hyttene er arealmessig segmentert til å redusere inngrep i mer urørte områder, og utformet for å gi mindre miljøbelastning. Neste skritt er å sette opp konkrete prosjekt for å etablere en «bærekraftig» utbygging.

På tross av noe ulik mottakelse var det likevel enkelte entreprenører som prøvde å utvikle slike prosjekt, om enn ikke direkte basert på konseptene fra «Grønn Fjellhageby». På en ekskursjon i september 2018 ble studenter på kurs i naturressursforvaltning vist lokaliteten for et slikt prosjekt plassert i landbrukslandskapet $10 \mathrm{~km}$ vest av Oppdal sentrum. 
Dette prosjektet strandet, men på ekskursjonen året etter fikk studentene se et liknende prosjekt i nabokommunen Rennebu. ${ }^{8}$ Dette prosjektet vil ha preg av «timeshare», og hyttene vil bli lokalisert i en klynge. Tegninger og prosjekt fremsto som delikate og med mindre miljøbelastning enn tradisjonelle hytter. Spørsmålet, som også mange av studentene stilte seg, er om det faktisk er marked for denne typen hytter. Dette er jo også avhengig av hvordan hyttemarkedet og folks økonomi utvikler seg. Ut fra møtet med Nasjonalparken Næringshage og involverte entreprenører er det ingen tvil om aktørenes ekte engasjement. Likevel kan en stille spørsmål ved om dette faktisk skaper en ekte vinn-vinn-situasjon. Under befaringen ble det sagt at samiske interesser på et mer generelt grunnlag er kritiske til all hytteutbygging, da den vil skape økt trafikk i utmarka - noe som også vil være tilfelle for dette konseptet. «Timesharekonseptet» kan tenkes å medføre at hyttene er «bebodd» i en lengre periode av året enn hva ellers vil være tilfelle, og slik sett skape enda mer trafikk ute i terrenget.

Slik jeg personlig kjenner de involverte aktørene fremstår ikke ideen om «Grønn Fjellhageby» som bevisst grønnvasking, men kan likevel ha en slik effekt. Videre er spørsmålet om dette vil slå igjennom hos det brede lag av utbyggere. Enkelte større utbyggere var ifølge vår informant noe kritisk, ${ }^{9}$ og en skal heller ikke glemme maktposisjonen til den etablerte hyttenæringen. Derfor er det et åpent spørsmål om vinn-vinn-diskursen om grønn hyttebygging i fremtiden vil etablere seg som en ny dominant diskurs. Ser en på miljøområdet ellers ser en ofte at «vinn-vinn-diskurser» fort blir utfordret av nye kritiske diskurser (Benjaminsen \& Svarstad, 2017). Diskursene Oppdal som natur og jordbruksbygda og Oppdal og dens arealbehov har begge potensiale for å ta denne kritiske rollen. Samtidig trengs det bærekraftige løsninger som gir levelige vilkår for alle berørte grupper. Fremtiden vil vise hvordan konflikten utvikler seg.

\footnotetext{
8 Dette prosjektet drøftes på websider utviklet av kursets studenter (Frenz et al., 2019; Kyaw et al., 2019)

9 Personlig kommunikasjon med anonym næringsutvikler på Oppdal 09.11.2019
} 


\section{Konklusjon: Fremtidens Oppdal - status quo eller ny retning?}

Oppdal-samfunnet har hatt en mer positiv utvikling enn mange andre distriktskommuner i Midt-Norge, ikke minst grunnet en destinasjonsutvikling basert på hyttebygging. Hvilke valg Oppdal-samfunnet velger for fremtiden, er uvisst og forbundet med spenning. Ulike interesser med ulike maktbaser trekker i ulike retninger. Ut fra dette er det mulig å identifisere fire ulike diskurser knyttet til arealforvaltningen på Oppdal, og da spesielt forvaltningen av utmarka.

Den fremtredende hyttekoalisjonen utgjør en til nå dominerende diskurs med sterke koblinger til viktige lokale entreprenører, til grunneierinteresser som vil tjene på tomtesalg og til lokale/regionale banker og handelsstand. Slik sett har de tradisjonelt hatt en solid maktbase til å dominere den lokale politikken. Imidlertid har denne dominante diskursen blitt utfordret av to mot-diskurser som er kritiske til forbruk og ødeleggelse av beitemarker og natur. Disse er også kritiske til kontinuerlig økonomisk vekst, og vil heller prioritere langsiktige kretsløpsressurser. For å imøtegå denne kritikken har det vokst frem diskurser rettet mot å få hytteutviklingen inn i et bærekraftig spor, dvs. skape en «bærekraftig utvikling». Dette kan sees som forsøk på å skape en «vinn-vinn-diskurs» som opphever motsetningene mellom den dominante diskursen og dens kritikere. Spørsmålet er om en slik omlegging kan la seg gjennomføre, eller om motkreftene er for sterke - eller om en faktisk velger en radikal løsning som tar avstand fra «evig økonomisk vekst».

Så hvordan vil maktbalansen mellom disse synspunktene utvikle seg videre? Selv om ingen i Oppdal-samfunnet brukte disse begrepene, kan en snakke om bærekraftig hytteutbygging som «økologisk modernisering» (Hajer, 1995; Mol et al., 2009). En bremsing av utviklingen kan i sin ytterste konsekvens peke i retning av det som ligger i tankene om «degrowth» (Demaria et al., 2013). Mest sannsynlig er nok at status quo, dvs. business as usual, eller kanskje riktigere, en økologisk justert business as usual. En fullstendig endring i retning økologisk landbruk og vern av kretsløpsressurser er nok lite sannsynlig. Hverken utviklingen innen Oppdal-samfunnet eller nasjonal politikkutforming peker i en slik retning. Eksempelvis er nasjonal landbrukspolitikk preget av 
modernisering og økt stordrift med færre og større gårdsbruk (SSB, 2019). Også virkemiddel-apparatet, som eksempelvis Innovasjon Norge, synes å støtte en eller annen form for økologisk justert business as usual. En må ikke glemme at Innovasjon Norge var den viktigste økonomiske bidragsyteren til masterplanprosessen, og at planen var utarbeidet basert på deres hvitebok for reisemålsutvikling (Innovasjon Norge, 2008). Hva som blir resultatet av rivningene mellom disse interessene vil fremtiden vise, og mye vil nok også avhenge av eksterne forhold.

Hytteutbygging er avhengig av eksterne kjøpere. Slik vil utviklingen i etterspørselen etter hytter være en viktig premiss. Som Benjaminsen og Svarstad sier må en i et politisk økologisk perspektiv alltid se på samspillet mellom ulike geografiske nivåer. Ingen forhold avgjøres bare på det lokale nivået. Her spiller marked, statlige regulering av landbruk og virkemiddelapparatet (f.eks. Innovasjon Norge) inn. Dagens situasjon i Oppdal er et resultat av samspillet mellom lokale forhold og eksterne faktorer. Det vil også fremtidens utvikling være. Den diskursive kampen vil heller ikke bare avgjøres internt på Oppdal. Hvilke diskurser som vinner vil i stor grad også avgjøres av hva som skjer utenfor det lokale nivået, eksempelvis vil diskurser rundt hytter og natur på et nasjonalt nivå slå hardt inn på det lokale planet.

Til slutt vil jeg peke på at drøftingen av konfliktene rundt hyttebygging og arealbruk på Oppdal ikke må sees som snever hytteforskning, men heller et forsøk på å utforske hvordan ulike diskurskoalisjoner og rivningene mellom disse formes av interessekampene i et lokalsamfunn, og samtidig hvordan resultatet av disse interessekampene vil kunne forme fremtidens lokalsamfunn. Lignende analyser kan overføres til en rekke areal- og ressursspørsmål, fra gruvedrift i Repparfjorden til vindkraft på Stadt.

\section{Referanser}

Adresseavisen. (2014). - Vi må rett og slett bygge bedre veier. Adresseavisen.

https://www.adressa.no/pluss/nyheter/article9842201.ece

Asplan Viak. (2013). Oppdal masterplan: Verdifulle fjellopplevelser. https://

masterplan.oppdal.com/

Benjaminsen, T. A. \& Svarstad, H. (2017). Politisk økologi: Miljø, mennesker og makt (2. utg.). Universitetsforlaget. 
Cameron, J. (2016). Focusing on the focus group. I I. Hay (Red.), Qualitative research methods in human geography (4. utg., s. 116-132). Oxford University Press.

Cristensen, T. B. (2019, 21. februar). Hyttebygging truer naturen i Norge. Naturvernforbundet. https://naturvernforbundet.no/uttalelser-fra-styrendeorganer/hyttebygging-truer-naturen-i-norge-article38933-2128.html

Demaria, F., Schneider, F., Sekulova, F. \& Martinez-Alier, J. (2013). What is degrowth? From an activist slogan to a social movement. Environmental Values, 22(2), 191-215. https://doi.org/10.3197/096327113X13581561725194

Engelstad, F. (1999). Om makt: Teori og kritikk. Gyldendal Norsk Forlag.

Enger, A., Iversen, E. K. \& Holmen, R. B. (2013). Ringvirkningsanalyse av reiselivsnoeringen i Oppdal 2011, og scenario 2018 (Menon publikasjon 7/2013). Menon Business Economics. https://www.menon.no/wp-content/uploads/ 1orapport-ringvirkningsanalyse-oppdal.pdf

Fairclough, N. (1992). Discourse and text: Linguistic and intertextual analysis within discourse analysis. Discourse and Society, 3(2), 193-217. https://doi.org/10.1177/ 0957926592003002004

Foucault, M. (2008). The birth of biopolitics: Lectures at the Collège de France, 1978-1979. Palgrave Macmillan.

Fouché, C. \& Light, G. (2010). An invitation to dialogue: 'The world café' in social work research. Qualitative Social Work, 1o(1), 28-48. https://doi.org/10.1177/ 1473325010376016

Frenz, G., Flessen, L. H., Gravelsæther, M. A., Ghimire, R. \& Fontanová, B. (2019, 15. november). Nerskogen sustainable cabins. NTNU. https://sites.google.com/ view/nerskogensustainablecabins/home

Flyvbjerg, B. (1998). Rationality and power: Democracy in practice. Chicago University Press.

Hajer, M. (1995). The politics of environmental discourse. Ecological modernization and the policy process. Oxford University Press.

Innovasjon Norge. (2008). Hvitebok for reisemålsutvikling (Innovasjon Norge rapport nr. 1/2008).

International Alpine Design. (2013). Ski area inventory + technical assessment Oppdal Skisenter, Norway. https://masterplan.oppdal.com/vedlegg/Masterplan-IAD_ Oppdal_Assessment_Report.pdf

Jære, H. (2018, 11. oktober). Hyttebygging uten bremser [Kronikk]. Adresseavisen. https://www.midtnorskdebatt.no/meninger/kronikker/2018/10/11/Hyttebygginguten-bremser-17668273.ece

Jämtland Härjedalen Turism. (2020). Gästnattsstatistik 2019 - helårsrapport. Jämtland Härjedalen Turism. https://jht.se/gastnattsstatistik-2019-helarsrapport/

Kaltenborn, B. P. (2018, 1. april). Hyttebyggingen har gått over alle støvleskaft [Kronikk]. Aftenposten. https://www.aftenposten.no/meninger/kronikk/i/ kay2nX/hyttebyggingen-har-gaatt-over-alle-stoevleskaft-bjoern-p-kaltenborn 
Krueger, R. A. (1994). Focus groups: A practical guide for applied research (2. utg.). Sage. Kyaw, H. Y., Köstenberger, S., Kvåle, E. K. \& Kongsmo, T. (2019, 15. november). Nerskogen sustainable cabin development. NTNU. https://sites.google.com/view/ nerskogen/menu

Marshall, J. (2016). First person action research: Living life as inquiry. Sage.

Mol, A. P. J., Sonnenfeld, D. A. \& Spaargaren, G. (Red.). (2009). The ecological modernisation reader: Environmental reform in theory and practice. Routledge. https://doi.org/10.4324/9781003061069

Nasjonalparken Næringshage AS. (2015). Hytteundersøkelsen i Oppdal 2015. https://oppdal.kommune.no/globalassets/pdfdokumenter/naring/rapporthytteundersokelse-2015-pdf.pdf

Nasjonalparken Næringshage, Trøndelag fylkeskommune \& Pir II. (2018). Grønn fjellhageby: Borekraftig hytteutbygging i fjellområder. Nasjonalparken næringshage. https://www.nasjonalparkhagen.no/uploads/1/1/2/o/112097601/ gfhb_hefte.pdf

Netto, S. V. F., Sobral, M. F. F., Ribeiro, A. R. B. \& Soares, G. R. L. (2020). Concepts and forms of greenwashing: A systematic review. Environmental Sciences Europe, 32. https://doi.org/10.1186/s12302-020-0300-3

Naalsund, T. O. (2018, 1. oktober). Frykter utbyggingstakten [Debattinnlegg]. OPP. https://www.opp.no/meninger/2018/10/o1/Frykter-utbyggingstakten-17610127.ece

Oppdalingen. (2016, 24. mars). Reindrift stopper hyttefelt. Oppdalingen. https:// www.opdalingen.no/nyheter/2014/o1/o3/Reindrift-stopper-hyttefelt-12507153.ece

Robbins, P. (2020). Political ecology: A critical introduction (3. utg.). Wiley Blackwell. Røskaft, M. (2009, 24. juni). Skiferindustrien i Oppdal. NRK. https://www.nrk.no/ trondelag/skiferindustrien-i-oppdal-1.6574012

Sandnes, R., Jakobsen, E. W., Enger, A. \& Iversen, E. K. (2013). Modell for fellesgodefinansiering i Oppdal (Menon-publikasjon nr. 13/2013). Menon Business Economics. https://www.menon.no/publication/modell-for-fellesgodefinansieringi-oppdal/

Sliper, J. O. (2020, 6. mars). Faktafredag - befolkning i Trøndelag per 1. januar 2020. Trøndelag fylkeskommune. https://www.trondelagfylke.no/vare-tjenester/planog-areal/kart-statistikk-og-analyse/nyhetsarkiv-kart-og-statistikk/faktafredagbefolkning-i-trondelag-per-1-januar-2020/

Statistisk sentralbyrå. (2019). Fakta om jordbruk. https://www.ssb.no/jord-skog-jaktog-fiskeri/faktaside/jordbruk

Statistisk sentralbyrå. (2020). Kommune Oppdal (Tøndelag - Trööndelage). Hentet 14.09.2020 fra https://www.ssb.no/kommunefakta/oppdal

Svarstad, H., Benjaminsen, T. A. \& Overå, R. (2018). Power theories in political ecology. Journal of Political Ecology, 25(1), 350-425. https://doi.org/10.2458/ v25i1.23044 
Toftaker, B. \& Toftaker, H. (2015). Vedr.: Innspill til Oppdal Kommunes arealplan ytterligere merknader til e-post, datert 30.01.15 [Høringsinnspill til kommunens arealplan]. http://93.89.112.77/eInnsyn/registryentry/ShowDocument?registry EntryId=114699\&documentId=165815

Wadel, C. (1991). Feltarbeid i egen kultur. SEEK AS.

Ygranes, J. E. (2020, 3. januar). Hytteutbygging truer norsk natur. Lidenskap for tur. https://lidenskapfortur.no/content/2019/10/hytteutbygging-truer-norsk-natur-2\#

Yin, R. K. (2018). Case study research: Design and methods (6. utg.). Sage.

Yu, E. P., Luu, B. V. \& Chen, C. H. (2020). Greenwashing in environmental, social and governance disclosures. Research in International Business and Finance, 52. https://doi.org/10.1016/j.ribaf.2020.101192

Aalbu, G. (2019). Oppdal - farming - possibilities and conflicts. 21.09.2018. (Oppdatert og presentert 11. september 2019). Foredrag av Gro Aalbu, Fagleder kultur, landbruk og miljø, Oppdal kommune.

Aall, C. (2017). Hyttelivet er ikkje lenger berekraftig. Syn og segn, (3). https://www. synogsegn.no/artiklar/2017/utg\%C3\%A5ve-3-17/carlo-aall/ 



\title{
Fritidsbygg i fjellområdet - en egen boligstruktur?
}

\author{
Tor Arnesen
}

Høgskolen i Innlandet

\section{Stine Kvamme}

Høgskolen i Innlandet

\begin{abstract}
There are as many leisure and second homes in the mountainous region of Southern Norway as there are primary detached house residences, and since 2000, more than three second homes have been built for every detached house. The balance in housing stock between primary and second homes is rapidly shifting towards secondary homes. More than half of the second homes in the region, and practically all those built since 2000, have high technical standards (water, sewage, road access, Internet service, electricity, etc). On average they are used 60 to 90 days a year (chiefly weekends and holidays), with frequency depending on their technical standard.

A recent demographic report reveals a declining and aging fixed population in the region and forecasts a continuing decline. Second homes in the region are mainly owned by those living in urban coastal areas outside the region, persons who are "invisible" in the local population analysis.

A good half of all second homes, particularly the high-standard ones, are in agglomerations in outlying areas, forming a "recreational sprawl" where urban and rural residences are linked by "recreational commuting". Covid-19 experiences, with widespread remote working from the second home, has also shown the elasticity between the two residential platforms.

More than just a leisure home, the second home agglomerations may be viewed more accurately as a unique housing stock being developed in mountain areas for part-time rural community inhabitants. A new demographic approach will be necessary to monitor this aspect of the population in many modern rural societies.
\end{abstract}

Keywords: second homes, demography, housing stock, recreational sprawl, recreational commuting

Sitering: Arnesen, T. \& Kvamme, S. (2021). Fritidsbygg i fjellområdet - en egen boligstruktur? I F. Flemsæter \& B. E. Flø (Red.), Utmark i endring (Kap. 5, s. 123-150). Cappelen Damm Akademisk. https://doi.org/10.23865/noasp.151.ch5

Lisens: CC BY-NC-ND 4.0 


\section{Innledning}

Nye tider er kommet. For de er her, de nye tettstedene i utmarka. De heter slikt som Sjusjøen, Hafjell, Kvitfjell, Bjorli, Beitostølen, Hemsedal, Hovden, Myrkdalen - for å nevne noen. Det finnes flere, og de vokser for tiden - i utmarka. De vegeterer på hypermobiliteten, enten den er fysisk eller digital, de samler ressurser, materielle og immaterielle, de organiserer og endrer måter å bo på, enten vi snakker arbeid eller fritid. De er nye økonomiske og politiske rom, de er nye fysiske strukturer i utmarka - og de er usynlige i innbyggerstatistikken.

I 104 kommuner i Sør-Norge klassifisert som «Fjellkommuner» og «Tilliggende fjellkommuner» (Arnesen et al., 2010), ${ }^{1}$ og lokalisert hovedsakelig på begge sider av Langfjella ${ }^{2}$ og videre nordover i Trøndelag, er det per mai 2020 vel 212500 eneboliger og vel 211 ooo fritidsboliger (Matrikkel, mai 2020). I disse kommunene har det, sett under ett og siden 200o-tallet, vært bygget om lag tre fritidsboliger for hver enebolig, så boligmassen forskyves raskt i retning av fritidsboliger. Fritidsboligene utvikles i dag så å si utelukkende som feltstrukturer i utmark (Arnesen \& Bryn, 2020; Arnesen et al., 2018), og per i dag ligger vel halvparten av fritidsboligene i det SSB karakteriserer som tettbygde fritidsbyggområder; områder med maksimalt 75 meter mellom ett bygg og det neste. Framveksten av disse fysiske fritidsboligområdene i utmarka er et signal om endrede bosettingsmønstre for en betydelig del av husholdningene i landet, en utvikling sentrale politikkområder langt på vei har vært blinde for (Arnesen et al., 2012; Ellingsen \& Arnesen, 2018; NOU 2020: 15; Skjeggedal \& Overvåg, 2015). Vi argumenterer dermed for at det er nyttig å forstå og omtale fritidsboligområdene som en egen og parallell boligstruktur til tradisjonell boligstruktur.

Er utviklingen av tettbygde fritidsbyggområder overraskende? Og hvorfor er det fruktbart å kalle disse områdene for en parallell boligstruktur? Er ikke hyttefelt mer treffende, ligger ikke det tettere opp til meningen med disse utbyggingene? Eller er det et eksempel på Ottar Brox', (2016, s. 74) påstand om at et «samfunn aldri kan bli et intendert produkt,

\footnotetext{
$1 \quad$ Klassifiseringen av kommunene er oppdatert for ny kommunestruktur som del av dette arbeidet

2 Langfjella er et samlenavn for fjellområdene fra Setesdalsheiene i sør til Dovrefjell i nord.
} 
slik en bygning kan det»? Er det grunnlag for å følge Brox videre når han hevder at et samlet utfall «kan mest fruktbart sees på som et tilfeldig sammenrasket aggregat av konsekvenser av individuelle handlinger, som hver for seg tar sikte på å oppnå noe positivt for aktøren» (Brox, 2016, s. 74)? Og er utviklingen kommet dit hen at den illustrerer Brox', poeng om at «samfunnsplanlegging kan ikke være noe annet enn forsøk på å redusere innslaget av tilfeldigheter - eller mer konkret: Unngå uønskede konsekvenser av vår individuelle jakt på det gode liv» (Brox, 2016, s. 74)? Åpenbart tar aktørene sikte på å oppnå noe positivt - men hvem er aktørene, og hva vil de oppnå? Aktør kan i denne sammenheng være byggherre, ${ }^{3}$ entreprenør ${ }^{4}$ eller myndigheter. ${ }^{5}$ Intensjonene er forskjellige for disse tre aktørkategoriene. Det vi i denne sammenheng er opptatt av er i første rekke myndighetene som gir byggene konsesjon. Vi må anta at myndighetene kan forventes å ha og ha hatt en overordnet plan eller intensjon med utviklingen av hytter/fritidsboliger i etterkrigstiden. Begrepet «individuelle handlinger» hos Brox skal forstås som at de enkelte handlinger ikke følger av en overordnet plan eller av det vi kan kalle en samfunnsplanlegging. Er det tilfelle for fritidsboligutviklingen? Er framvoksende (emergente) ansamlinger av fritidsbyggområder å forstå som et sammenrask av enkeltstående beslutninger som ikke har noen sammenheng med hverandre ut over at de dreier seg om bygninger i felt og med samme formål?

\section{Konseptualisering}

Det som gjerne kalles «konseptualisering» er en prosess for å danne begrep eller ideer som sier noe overordnet og samlende om det som refereres til. I denne sammenheng er det begrep eller ideer som sier noe mer om hyttefenomenet enn for eksempel SSBs begrep «fritidsbyggområde», eller bare hyttefelt. Vi leter etter noe som har samme kvalitet som for

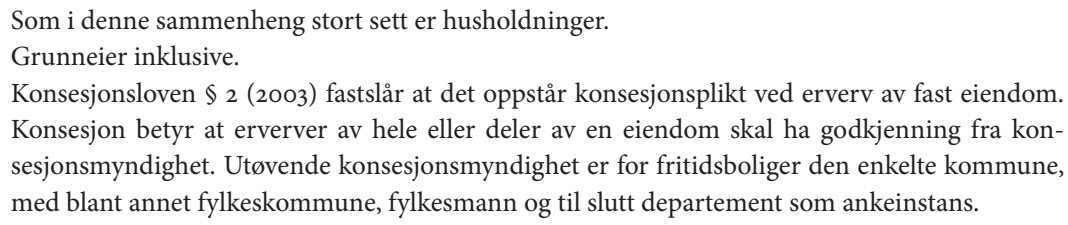
sesjonsmyndighet. Utøvende konsesjonsmyndighet er for fritidsboliger den enkelte kommune, med blant annet fylkeskommune, fylkesmann og til slutt departement som ankeinstans. 
eksempel boligområde eller boligfelt, eller sågar tettsted. Dette er begreper som har kjente konnotasjoner eller tilhørende meningsinnhold, og er mellomnivåbegreper som igjen inngår i mer overordnede teorier og ideer, som for eksempel rurale samfunn, distriktsutvikling og så videre.

Grounded theory (Strauss \& Corbin, 1997) er en i hovedsak induktiv metodikk ${ }^{6}$ som gir retningslinjer for å samle, analysere og altså danne et begrep eller en idé som sier noe overordnet om fenomenet og den sammenhengen det inngår i. Data, eller informasjonen som benyttes, kan være kvalitative og kvantitative (Glaser, 2007), men resultatet, begrepene, ideene eller konseptualiseringen, har en kvalitativ karakter i sitt forsøk på å «fange» datasettet under overordnede begrep som igjen kan inngå som del av en teoriutvikling. Ambisjonene er å levere teoribidrag som starter med et empirisk fenomen (fritidsbyggutviklingen) og så å si «trekke ut» av et begrep eller en idé som kan begrunnes med den informasjonen som det henvises til.

Data- eller informasjonstilfanget vi refererer til her er mangefasettert. Det summerer opp og viderefører en serie analyser av fritidsboligfenomenet (Arnesen \& Bryn, 2020; Arnesen et al., 2010, 2018; Overvåg \& Arnesen, 2007). Det omfatter matrikkeldata, geografiske analyser, brukeranalyser, økonomiske analyser og plan- og politikkanalyser som er utviklet gjennom en rekke år. Gitt et slikt mangefasettert datatilfang med en miks av kvantitativ og kvalitativ empiri, er oppgaven her av kvalitativ art. Artikkelen er et forsøk på å fortolke en utvikling ved en konseptualisering som binder sammen og finner en retning i datamaterialet.

Datamaterialet som undersøker fenomenet fritidsboliger har forskjellig faglig plattform, og videreutvikler begrepsmessig tidligere arbeider (Arnesen \& Ericsson, 2013; Arnesen et al., 2018; Arnesen \& Skjeggedal, 2003; Overvåg, 2009, 2011; Skjeggedal et al., 2009, 2015). Progressivt bygges mer abstrakte eller omfattende kategorier til vi når en «metning» med begrepet «grønn boligstruktur». Denne oppbyggingen av et begrepshierarki fra bygning til overordnet struktur blir behandlet i påfølgende tekst, og vist skissemessig i påfølgende tabell.

6 I denne sammenheng kan vi si at en induktiv metode går fra de enkeltobservasjoner til ideer eller begreper om hva observasjonene et uttrykk for. 
Tabell 1. Begreper på vei mot oppsummeringen i et samlebegrep

\begin{tabular}{l} 
Observasjoner og tilhørende begreper som leder fram til \\
eller inngår i et samlebegrep \\
(begrepene behandles mer utførlig i påfølgende tekst): \\
\hline - Fra hytte til fritidsbolig \\
Primært en teknisk utvikling fra enkle bygninger ikke \\
påkoblet infrastruktur som vann, avløp, vei, digital struktur \\
osv.
\end{tabular}

\section{- Fritidsbyggområde}

Følger SSBs definisjon av tettbygde fritidsbyggområder, som for eksempel maksimalt 75 meter mellom ett fritidsbygg og det neste for tettbygde fritidsbyggområder.

- Fysisk distanse til rurale sentra

Observasjon av et særegent trekk ved fritidsboligutviklingen i fjellområdet; områdene utvikles med god fysisk distanse til etablerte rurale sentra; det er ingen fortrengingseffekt hva angår boligtilgang (slik det tidvis kan være langs kysten).

\section{- Hinterlandsfenomen}

Primært fra observasjon av et utbyggingsmønster som preger rurale fjellområder i baklandet til (stor-)byregionene. For kystens del er situasjonen noe annerledes; fokus her er på fjellområdene (se figur 1).

- Økonomiske, tekniske og funksjonelle utviklingsimperativer

Primært fra observasjonen at fritidsboliger krever tilknytning til fysisk infrastruktur, noe som igjen skjer som en feltmessig utvikling for å effektivisere investeringer, inngrep og bokomfort som kan mobiliseres fra «dag 1».

\section{- Rekreativ byspredning}

Primært fra observasjon av formål med, eierskap til og lokalisering av byggene i relasjon til boligene i byregionene.

\section{- Rekreativ pendling}

Primært fra observasjon av den type mobilitet og bruksmønster som fritidsboligen skaper, ikke minst med hyppig helgebruk i tillegg til lengre ferieperioder. Mer utpreget i fjellområdene fordi det her er både en barmarksog en snødekkesesong, men langs kysten er preget av sen vår-/sommersesong.

\section{- Deltidsbeboer}

Primært fra observasjon av hyppige og samlet sett mange og regulære opphold i fritidsbyggområdene - og fordi deltidsbeboeren har investert i bolig.

\footnotetext{
- Flerhushjemmet

Primært fra observasjon av at husholdninger som fordeler sine hjemfunksjoner på, typisk, en bolig i byen og en fritidsbolig i det rurale hinterland (i alle fall hva angår fjellområdene).
}

Summeres opp i:

«Grønn boligstruktur»

(«Grønn» er her ment kun som en merkelapp for å skille fra tradisjonell boligstruktur i og utenfor tettsteder, som vi kaller «rød» boligstruktur, samt for å markere at den observerte utviklingen skjer så å si utelukkende i utmarksområder) 
Grounded theory forstått slik er egnet nettopp til å avdekke og karakterisere emergente eller framvoksende utviklingsforløp, og da særlig ikke kartlagte, betingede og dynamiske fenomen. Tilnærmingen gir rom for å drøfte gamle egenskaper ved studerte fenomen som igjen former nye forhold, og konsekvenser av disse - i denne sammenheng framvekst av en fritidsboligkultur som avviker betydelig fra hyttekulturen slik den utviklet seg i mellom- og etterkrigstiden (Arnesen \& Ericsson, 2013; Arnesen et al., 2018; Holz \& Haagensen, 2018; Haagensen, 2019; Skjeggedal \& Overvåg, 2015).

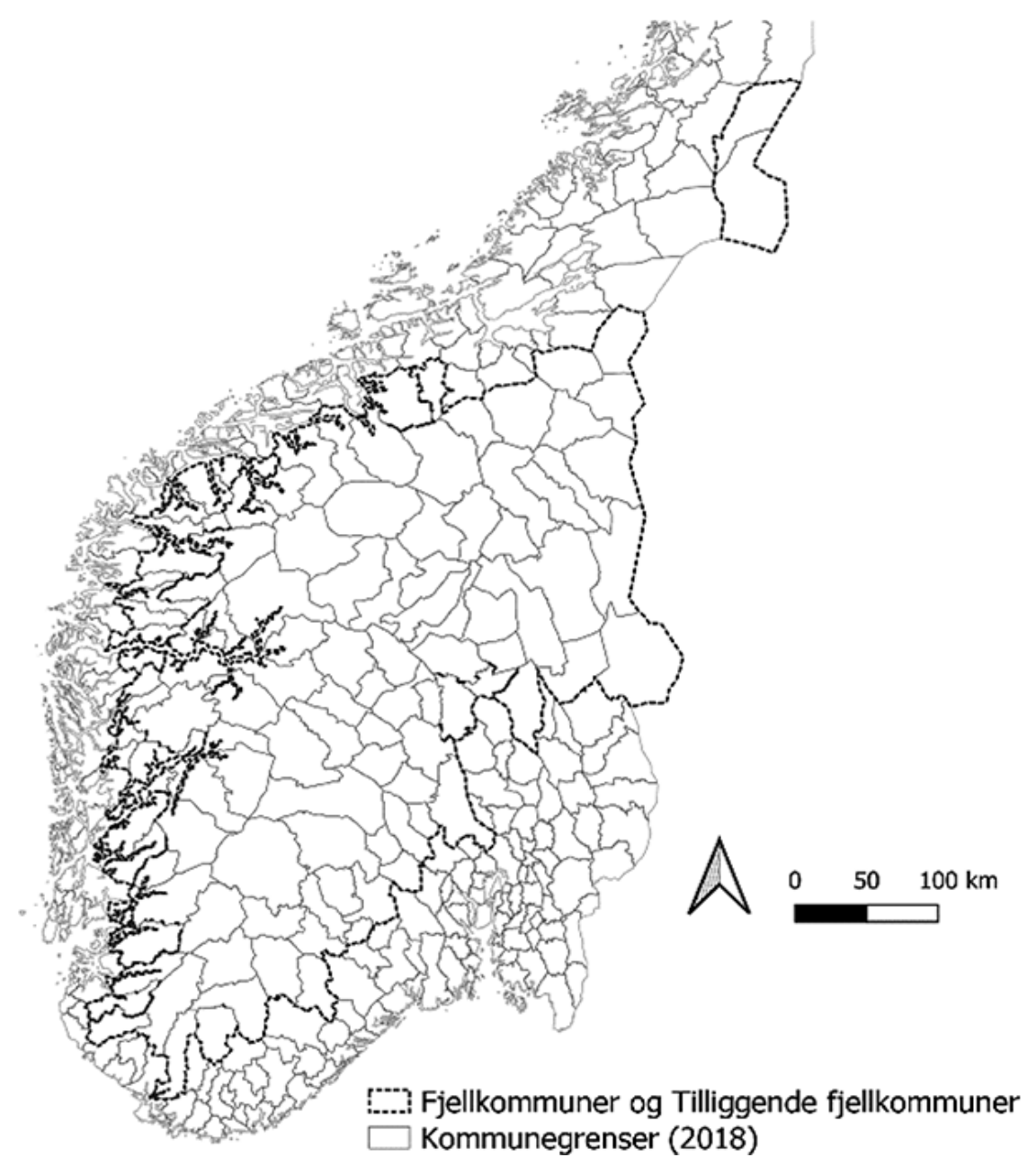

Figur 1. Det indre fjellområdet med 104 kommuner. Kilde: Arnesen et al., 2010, oppdatert for ny kommunestruktur. 
Området som observasjoner, informasjon og data primært er hentet fra, er vist i figuren som «Fjellkommuner» og «Tilliggende fjellkommuner». Det er til sammen 104 kommuner i Sør-Norge - et område som kalles for «fjellområdet» i det følgende (Arnesen et al., 2010). Med unntak av to kommuner (Lillehammer og Ringsaker) omfatter disse flertallet av distriktskommuner i Sør-Norge. Det er i denne sammenheng tilstrekkelig å peke på at disse kommunene, med svært få unntak, registrerer fraflytting og en har demografisk pyramide som er topptung med en aldrende befolkning og synkende fødselstall (NOU 2020: 15). Skal vi med et enkelt sveip over dette området karakterisere en utvikling som mer enn noe annet har preget etterkrigstiden, så er det urbanisering og befolkningsnedgang. Urbaniseringen som forenklet sagt har trukket folk og funksjoner fra fjellet til sentrale strøk, det vil si langs kysten for Norges del (Arnesen et al., 2010; McArthur et al., 2014; Rye, 2006; Schmied, 2005).

Desto mer påfallende er at i det samme fjellområdet bygges flere boliger enn noen gang, men altså som fritidsboliger i utmarka. For cirka 40 av kommunene er det i dag flere fritidsboliger enn boliger. Forholdstallet mellom bygging av «vanlige» boliger og fritidsboliger i fjellområdet sett under ett, har på 200o-tallet vært 1:3.

\section{Utbyggingsperioden fram mot slutten av 1980-tallet}

Tidlige innspill til samfunnsplanlegging for denne sektoren fulgte i hovedsak to spor, ett for fjellområdene og ett for kystområdene. I denne $^{2}$ sammenheng er tema utviklingen i fjellområdene.

Daværende kommunal- og arbeidsminister Andreas Cappelen anmodet i 1962 Axel Sømme ${ }^{8}$ om utkast til reguleringsmodeller i fjellområder

$7 \quad$ For kysten var det først og fremst tiltak som omfattet indre og ytre deler av Oslofjorden. Et tidlig tiltak i de ytre delen av Oslofjorden var etablering av skjærgårdsparken. Arbeidet ble påbegynt i 1974/75 av det da nyopprettede Miljøverndepartementet. Parken har primært som formål å sikre allmennhetens tilgang til skjærgården i 600 enkeltområder på til sammen 62 ooo dekar i strekningen fra Langesund til og med Farsund. Som en følge av det ble bruk av areal for fritidsboligformål begrenset.

8 Økonomisk geograf og professor ved Norges Handelshøyskole 1948-1969. 
av særlig interesse for fritids- og ferielivet. Dette resulterte i rapporten Fjellbygd og feriefjell (Sømme et al., 1965). Rapporten har bidrag fra åtte forskere. Det er et omfattende verk fra det som ble kalt «Fjellplanteamet». Teamet presenterer forskjellige modeller for hytteutvikling - så å si alle i form av hyttegrender. 9 I løpet av arbeidet til Fjellplanteamet ble det i 1963 også nedsatt en «Fjellplankomité» med den gang sosialminister Olav Gjerdevoll som formann - antakelig da i kraft av sin professorstilling i biologi ved Norges lærerhøgskole (1958-1986). Komiteens mandat var å lage et utkast til ny fjellplanlov, og hvor Fjellplanteamets arbeid skulle gi et kunnskapsgrunnlag. Strand- og fjellplanloven ble endelig vedtatt i 1971, og senere innarbeidet i plan og bygningsloven av 1984.

Rapporten Fjellbygd og feriefjell vender seg «først og fremst til allmennheten for å stimulere til offentlig debatt, idet vi regner med at de nødvendige nye lovbestemmelser vil komme før eller siden» (Sømme et al., 1965, s. 6). Noen omfattende debatt i allmennheten ble det vel ikke i kjølvannet av rapporten. Til det var antakelig fenomenet «hyttegrender» for abstrakt - selv om 6o-tallet opplevde en betydelig årlig vekst i antallet hytter - i størrelsesorden 10 ooo årlig (Arnesen \& Ericsson, 2013).

Men hvilke krefter er teamet opptatt av? Det er en til dels forbausende opptatthet av å tiltrekke seg innvandrere og forhindre hjerneflukt (brain drain) gjennom å legge til rette for å utvikle feriefjell. Sømme et al. skriver:

Skal vi kunne holde på våre beste folk, eller regne med innvandring av mennesker av samme kvalitet, må vi kunne by dem trivselsverdier som de ikke kan få i de store sentra: eget hus [...] og lett adkomst til vakker natur [...] $\AA$ skape trivsel for den befolkning som er sysselsatt i bynæringene og å styrke næringsgrunnlaget i fjellbygdene ved større salg av fritidsgoder, betyr etter forfatterens mening på lengre sikt å sikre Norge en større andel av den internasjonale turiststrøm. [...] Utlendinger, som kommer til vårt land fra trengselen $\mathrm{i}$ Europas storbyer, må ikke komme opp i ny trengsel for å nå sitt feriested i Norge. (Sømme et al., 1965, s. 10)

9 I tillegg behandles også den økonomiske betydningen for vertskommuner av hytteutviklingen, forholdet til landbruksvirksomhet og som naturinngrep. Disse sidene ved arbeidet lar vi ligge i denne sammenheng. 
Et overraskende perspektiv, men av mer vedvarende relevans, er det at Fjellplanteamet så på utviklingen av hyttegrender i perspektivet byland, eller urban-rural. Planperspektivet er hvordan legge til rette for at «byfolk» ved tilgang til en fritidsbolig/hytte skal nyte rurale ressurser for ferie- og fritidsformål.

Spoler vi fram til dagens situasjon, så er dette en realitet som et levd fenomen, men ikke som et planfenomen. Denne invitasjonen til en type samfunnsplanlegging, ble aldri fulgt opp. Det kommer vi tilbake til. ${ }^{10}$

Dette i dag noe fremmede perspektiv på behov for å regulere utbygging av feriefjellet ble fulgt opp i fysisk planlegging. Det skjedde med to utgangspunkt: (1) gjennom kompetanse tildelt den enkelte kommune hva angår arealbruk, og (2) en statlig politikk for verneområder (først og fremst nasjonalparker og landskapsvernområder). Et viktig grep ble å legge en planstrategi hvor enkelte områder i fjellet ble bevart, mens andre områder kunne brukes til større hyttegrender. I første rekke ble dette operasjonalisert gjennom områdevern med nasjonalparker, naturreservater og etter hvert landskapsvernområder. Fra inngangen til 1970tallet til utgangen av 1980-tallet økte vernet areal som nasjonalpark med 150 prosent, fra 5000 til $12500 \mathrm{~km}$ (Statistisk sentralbyrå, 2021). Landskapsvernområder økte med like under 1900 prosent, fra 215 til $4200 \mathrm{~km}$ allerede på 70-tallet (Miljøverndepartementet, 1977). Dette skjedde så å si utelukkende i fjellområdet (Statistisk sentralbyrå, 2021). Vi hevder ikke at verneområdepolitikken var forårsaket av Fjellbygd og feriefjell, men at utviklingen av hyttegrendene til Fjellplanteamet for så vidt var forenlig med og støttet opp under verneområdepolitikken.

Fjellplanteamets hyttegrender var ment å gi grunnlag for å organisere avløp og renovasjon for å redusere forurensing. Som det framgår av denne første generasjons hyttepolitikk var det ikke snakk om å bremse en utvikling, snarere tvert imot. Dette kommer også eksplisitt til uttrykk når Miljøverndepartementet i et rundskriv i 1977 skriver: «Målet er å legge forholdene til rette slik at flest mulig av de som ønsker det, kan skaffe seg egen hytte eller adgang til å bruke hytte» (Miljøverndepartementet, 1977). 
I 1981 leverte det såkalte Hytteutvalget sin rapport, og pekte på «behovet for et aktivt sentralt engasjement for å legge til rette for fritidshusbygging» (NOU 1981: 21, s. 77). Hva angår utbyggingsmodeller, følger utvalget i fotsporene til Fjellplanteamet. ${ }^{11}$

\section{Utviklingen fram mot dagens situasjon}

Nok et typisk trekk ved fritidsboligstrukturen i fjellet er at den er lokalisert i god avstand fra den tradisjonelle tettsteds- og boligstrukturen. Denne er gjerne lokalisert i dalbunn, mens fritidsboligstrukturen har klatret opp dalsiden og gjerne innover utmarka. Fritidsboligstrukturen er altså liggende i utmark, planteknisk med arealformål «fritidsbebyggelse» (Arnesen, 2015). Men i liten og avtagende grad er fritidsboligstrukturen lokalisert på snaufjell (Arnesen \& Bryn, 2020) eller i åpent landskap (Arnesen et al., 2018).

Et annet trekk ved utviklingen av fritidsboligstrukturen er at den i sterkt økende grad foregår som en feltmessig utvikling. Veksten i perioden 2000 til 2018 har konsolidert feltutbygging som den dominerende strukturen. Utviklingen går mot stadig færre og større felt, mens den spredte utbyggingen nærmest har stoppet opp (Arnesen et al., 2018).

Fritidsbyggområdene smelter sammen, blir større, og med det færre. Det er flere grunner til dette, grunner som kan summeres opp som økonomiske, teknologisk og funksjonelle imperativer eller føringer. Nye og etterspurte fritidsbygg er i dag, og har vært på hele 2000-tallet, teknisk på høyde med vanlige eneboliger. Det vil si tilgang til infrastruktur, som vei, strøm, vann og avløp, og som regel kommunikasjonsteknologi som bredbånd. Dette er til sammen investeringstunge forutsetninger som fører til en feltmessig utvikling. Funksjonelt er de knyttet til områder som i dagens marked må ha tilgang til stier, løyper, bakkeanlegg og liknende aktivitetsanlegg; igjen investeringstunge og institusjonskrevende forutsetninger. I tillegg er det så å si slutt på å gi tillatelse til spredt fritidsbyggutvikling.

11 Interessant i denne sammenheng er også Langdalens refleksjon noen år senere om den kontroversielle hytteutviklingen i Norge som et planleggingsproblem (se Langdalen, 1980, 1992). 
Det er med andre ord en tettstedsutvikling for fritidsformål i utmark vi snakker om her, hvor tettstedene fortettes og vokser.

\section{Overalt?}

Lokaliseringsmessig ligger feltene typisk fra to til fire kjøretimer fra sentrale byregioner: Oslo, Stavanger, Bergen og Trondheim (Ellingsen, 2016; Overvåg, 2011; Overvåg \& Arnesen, 2007) - det vi kan kalle for hinterlandseffekten. Dette er et mønster som er lett synlig i kartet i figur 4-og i figur 2 som viser hvor de bor, husholdningene som eier fritidsboliger i fjellområdet.

Arealmessig legger fritidsbygg i fjellområdet beslag på en beskjeden del av det samlede arealet:

Tabell 2. Arealbruk knyttet til fritidsbygg i fjellområdet. Hvert fritidsbygg er tildelt 4 mål, overlappende arealbeslag er slått sammen. Kilde: Arnesen et al., 2018

\begin{tabular}{lcc}
\hline & $\begin{array}{c}\text { Sum areal } \\
\mathbf{k m}^{2}\end{array}$ & $\begin{array}{c}\text { Fritidsboligfeltenes } \\
\text { andel av samlet areal } \\
\mathbf{2 0 1 0} \mid \mathbf{2 0 1 8}\end{array}$ \\
\hline Fjellkommuner og Tilliggende fjellkommuner & 110133 & $0,56 \% \mid 0,63 \%$ \\
\hline
\end{tabular}

Fritidsboligområdene er mer distribuert i landskapet enn den tradisjonelle boligstrukturen i de rurale områdene hvor dette utfolder seg, og områdene ligger gjerne ikke langs hovedfartsårene slik tettsteder gjerne gjør.

Med alle fritidsbygg i fjellområdet, kan vi gjøre følgende tankeeksperiment for å illustrere fritidsbyggenes distribusjon i landskapet: Du blir droppet fra oven på et tilfeldig sted i fjellområdet med lik sannsynlighet for å havne på ethvert punkt i fjellområdet. Det er da 82 prosent sannsynlighet («droppsannsynlighet») for at du ikke finner et eneste fritidsbygg innen en kvadratkilometer. Droppsannsynligheten for å havne på en kvadratkilometer med ett eller to fritidsbygg er 10 prosent. Droppsannsynligheten for å havne i en kvadratkilometer med fra tre til fem fritidsbygg er 4 prosent. Droppsannsynligheten for å havne i en kvadratkilometer med fra seks til ti fritidsbygg er 2 prosent. For å havne i en kvadratkilometer med mer enn 10 fritidsbygg er sannsynligheten fra 1,5 prosent til neglisjerbar. 


\section{Hvem bebor fritidsboligene, når og hvor kommer de fra?}

Husholdninger bebor fritidsboliger. Vi vet om bruksmønster og boligene i fjellområdet, at:

- Den store majoriteten eies av husholdninger i byen - og da stort sett innenfor en radius på tre til inntil fire timers kjøring fra sentrale byregioner. 80 prosent av fritidsbyggene i fjellområdet eies av husholdninger utenfor fjellområdet, og da i første rekke husholdninger med bolig i storbyregionene (Holz \& Haagensen, 2018) - se figur 4.

- Det bør skilles mellom ytterpunktene teknisk lavstandard fritidsbygg (uten veiframføring, ikke innlagt vann og avløp, ikke med strømframføring) og teknisk høystandard fritidsbygg (vei, vann, avløp, strøm). Anslagsvis er godt over halvparten av dagens fritidsbygg i fiellområdet på høystandard-siden av spekteret; og det omfatter så å si alle som er bygget siden 2000, og flertallet er bygget i felt med minst 50 fritidsbygg (Haagensen, 2019; Statistisk sentralbyrå, 2017).

- Høystandard fritidsbygg brukes typisk mye, med et gjennomsnitt som varierer mellom 60 til 90 overnattingsdøgn i året, lavstandard vesentlig mindre (Ericsson \& Flognfeldt, 2018b, 2018a; Skjeggedal et al., 2015)

- Høystandard fritidsbygg brukes hyppig på helgebasis både i snøsesong og barmarksesong, i tillegg til lengre opphold i klassiske ferieperioder som påske, og i økende omfang jul og nyttår. Lavstandard er mer konsentrert rundt lengre ferier.

Mobiliteten mellom boliger i storbyområdene og tilhørende fritidsboliger i utmarka i fjellområdet kan forstås som rekreasjonspendling. Fritidsboligstrukturen kan også ses på som en type byspredning for rekreative formål; en rekreativ byspredning (Arnesen et al., 2010, 2012; Skjeggedal et al., 2015), eller slik Ellingsen gjør, se på det som en type desentralisering 


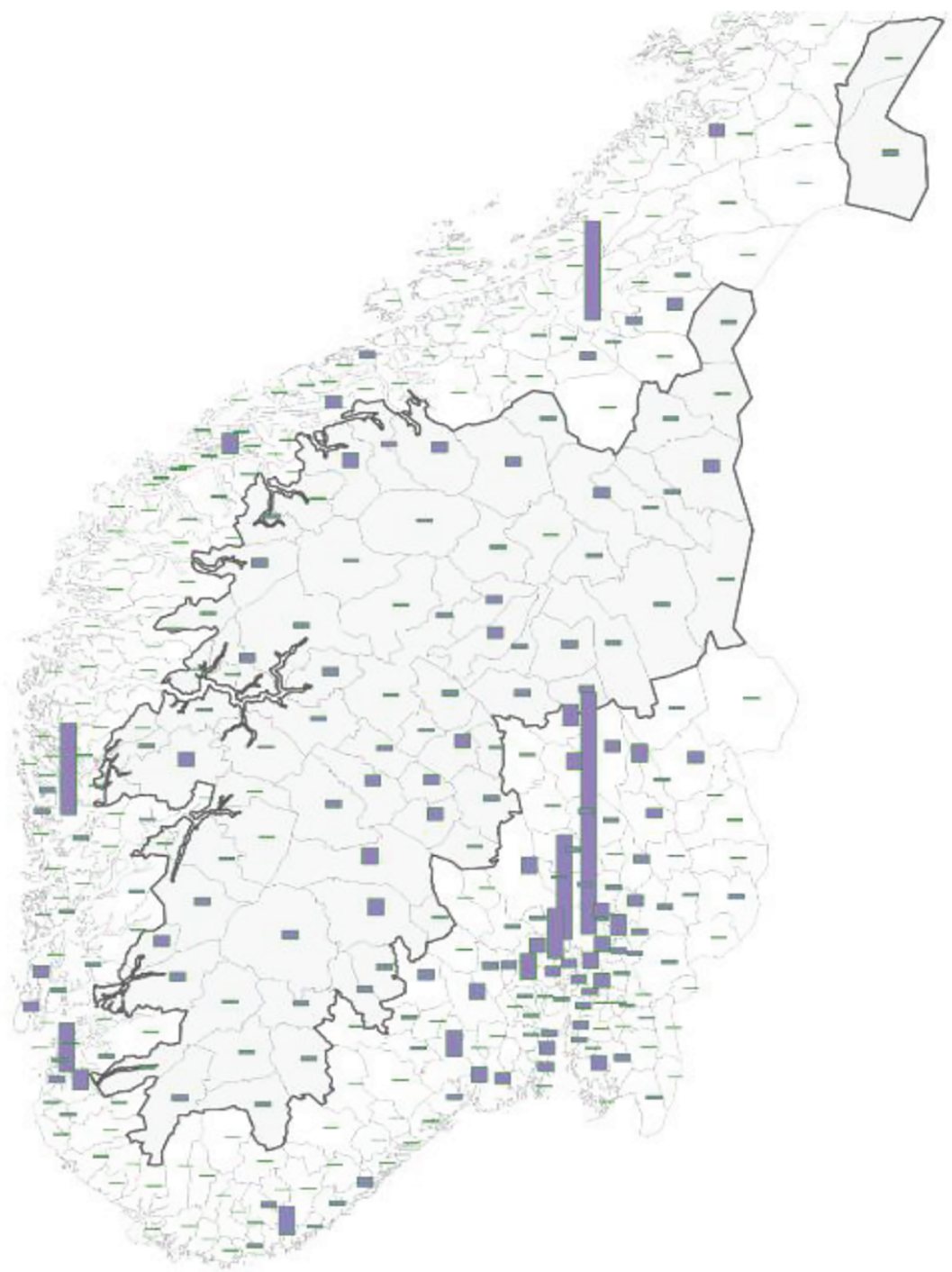

Figur 2. Stolpene viser hvor husholdningene med fritidsbolig i fjellområdet bor (fritidsbolig i egen kommune er holdt utenfor). Kilde: Kartverket. Figur: Høgskolen i Innlandet.

av husholdningers hjemfunksjoner (Ellingsen, 2016; Ellingsen \& Hidle, 2013). Ellers er denne formen for utvikling noe man finner i flere land (Duschene-Lacroix et al., 2014; Flognfeldt, 2004; Gallent, 2006; Müller, 2002). 
For tradisjonell boligstruktur har vi tilhørende begreper på plass; de er bebodd av husholdninger, de er heltidsboende, og er innbyggere med retter og plikter vedheftet. En annen avklart kategori er turisten; reiselivets klassiske aktør. Turisten, som i prinsippet kommer en gang og leier husvære, for så å reise videre. Turisten har ingen innbyggerretter eller plikter, er av alle typer fra enkeltpersoner, til grupper og til familier på tur. Turisten kommer enkeltvis eller samlet.

\section{Deltidsboende i fritidsboligene}

Heltidsboende og turisten er kjente kategorier. Inn kommer deltidsboende. Tabellen skiller ut noen sentrale spesifikasjoner for hver av de tre kategoriene, inklusive for deltidsboende som kiler seg inn mellom turisten og heltidsboende.

Tabell 3. Tre typer tilstedeværelse

\begin{tabular}{lllll}
\hline TYPE & \multicolumn{3}{c}{ I VERTSKOMMUNEN: } \\
\cline { 2 - 5 } HUSHOLDING: & Investering i bolig & Tilstedeværelse & Formål \\
\hline Heltidsboende & $\mathrm{Ja}$ & - Daglig/permanent & Fast- & Dagligliv \\
Deltidsboende & $\mathrm{Ja}$ & - Regulært gjentagende & boende & Fritid \\
Turisten & $\mathrm{Nei}$ & - En/ noen gang(er $)$ & & Fritid \\
\hline
\end{tabular}

Deltidsboende likner heltidsboende ved å ha investert i en bolig, dermed er de permanent til stede som økonomiske aktører. Deltidsboende likner turisten ved at formålet med oppholdet er rekreasjon eller fritidsaktivitet. Deltidsboende er forskjellig fra begge ved å være regulært, midlertidig men gjentagende til stede. Slike karakteristika gjør det uhensiktsmessig å redusere deltidsboende til den ene eller andre av de to øvrige kategoriene (Arnesen et al., 2010, 2012).

\section{Flerhushjemmet}

Deltidsboende blir dermed en variant av heltidsboende - men begge er like «faste» i sin innbyggerkategori. For den deltidsboende er det antakelig mer dekkende å snakke om at de bebor flerhushjemmet og at de strengt 
tatt er deltidsboende både i fritidsboligen og i boligen. ${ }^{12}$ Flerhushjemmet er da et hjem for husholdninger som organiserer hjemfunksjoner over mer enn ett hus eller en bolig. Den konfigurasjonen som er mest relevant, er en bolig i byen som primært huser dagliglivet, jobb, skole og så videre, og en bolig, en fritidsbolig (i dette tilfellet i fjellområdet) som primært fyller rekreasjons- eller fritidsfunksjon. Fordelingen mellom de to settene av funksjoner kan endres over tid, blant annet er det mulig å tenke seg at i perioder hvor jobb og skole krever mindre tilstedeværelse i by-boligen, så brukes vesentlig mer tid i fritidsboligen (Arnesen \& Skjeggedal, 2003; Skjeggedal et al., 2009, 2015). Pensjonistfasen er en slik mulig fase, men den pågående koronapandemien har vist at også andre situasjoner lett kan melde seg hvor det av mange oppfattes om et gode å forlate byen til fordel for fritidsboligen.

Situasjonen i Norge er ikke unik, slik også Flognfeldt (2004) diskuterer i en tidlig artikkel om den norske varianten av fenomenet. I flere områder, både i Europa og andre områder i verden ellers, har liknende fenomen vokst fram. Allerede i 1995 diskuterte McHugh et al. (1995) fenomenet syklisk migrasjon mellom flere boliger, da i et livsløpsperspektiv. Senere har han sammen med McIntyre og flere i et viktig verk særlig sett på relasjonen fritidsboliger og boliger (McIntyre et al., 2006) hvor begrepet «multiple dwelling» er sentralt.

Quinn (2004) diskuterte for så vidt allerede i 2004 «dwelling thorugh multiple places» nettopp med utgangspunkt i fritidsboliger. Hun videreførte det som en diskusjon om meningen med fritidsboliger.

Duval (2004) bruker begrepet «mobile migranter» for å beskrive et liknende fenomen. Müller og Marjavarra (2012) har beskrevet liknende fenomen i Sverige. Duschene-Lacroix med flere (2014) har en drøfting av «multilokales Wohnen» i Sveits hvor fritidsboligfenomenet er i fokus og hvor det trekkes sammenlikning med situasjonen i blant annet Norge. Perlik (2010) har også drøftet fenomenet slik det utfolder seg i alpeområdet.

12 Man kan nemlig innvende at det inviterer til en logisk begrepsforvirring å snakke om at en og samme husholdning kan være heltidsboende ett sted og deltidsboende et annet. Dersom deltid og heltid har samme referanse, nemlig botidsbruken som sådan, så følger at en og samme husholdning snarere bor deler av tiden i hver av boligene, og ikke heltid i noen av dem. Det er bare hvis de to har forskjellig referanse, at begrepsparet virker. Med heltidsboende menes da mer enn botiden, nemlig at adressen er registrert ved den boligen som har status som heltidsbolig. 


\section{Deltidsboende og demografien}

Husholdningene er aktørene i flerhushjemmet. I dag er det noe i overkant av en fjerdedel av husholdningene i landet som eier fritidsbolig. Andelen varierer regionalt, med inntektsgrupper, aldersgrupper og andre sosiale karakteristika (Arnesen et al., 2018).

Så et spørsmål blir: hvor er deltidsboende i tellinga av innbyggere i en kommune? Usynlige. Deltidsboende er statistisk (og fiskalt) «usynlige innbyggere» $\mathrm{i}$ en kommune. På styringsnivå er det mangel på informasjon om hvordan, av hvem og når fritidsboligstrukturen bebos.

Men deres tilstedeværelse er ikke ukjent, dog ikke mer kjent enn at den kommer som en overraskelse og et problem når det er behov for å innlemme dem i forskjellige lokalsamfunnssammenhenger. Et eksempel på det er de erfaringer flere fritidsboligkommuner gjorde under koronapandemien med utbrudd senvinter og vår 2020 (Arnesen, 2020a, 2020b). Det viste med all tydelighet at fritidsboligstrukturen er et samfunnsfenomen som på en grunnleggende måte har introdusert en ny type organisering av husholdningers familieliv og som derfor stiller samfunnet for nye utfordringer.

Demografiutvalget (NOU 2020: 15) har analysert den demografiske utviklingen $\mathrm{i}$ «de mindre sentrale områdene av landet» (s. 18), og dette omfatter særlig de indre fjellområdene i landet. Utvalget slår fast at «Fritidsboliger gir høyere faktisk innbyggertall» (s. 32), men disse husholdningene er langt på vei statistisk usynlige. For som utvalget slår fast:

Analysene av bosettingsmønsteret baserer seg på Folkeregisterets opplysninger om hvor folk bor. Folk tilbringer imidlertid en større del av tiden sin i rurale områder enn innbyggertallene skulle tilsi. Den økende byggingen av hytter og $ø k t$ bruk av fritidsboliger i helger og ferier av bybefolkningen er sett på som en sterk moturbaniseringsprosess. (NOU 2020: 15, s. 32)

«En sterk moturbaniseringsprosess» som det enøyde blikket på den tradisjonelle boligstrukturen er blindt for, og som i neste omgang ligger til grunn for utforming av grunnleggende sivil infrastruktur som helsevesen, brannvesen, politi og justisvesen og så videre. Myndighetene nedla under koronaepidemiens innledende fase i mars og april 2020 tidsbegrenset forbud ved lov om opphold på fritidsbolig på grunn av en uklar og til dels 138 
udefinert frykt for å overbelaste sentrale velferdsinstitusjoner. Dette viser at deltidsboende vel kan oppfattes som en trussel mot etablerte institusjoner; eller, for å snu på flisa, at grunnleggende institusjoner innenfor sivil infrastruktur ikke har fulgt med på utviklingen av ny boligstruktur.

\section{Konseptualisering - grønn og rød boligstruktur}

Som denne gjennomgangen viser, har utviklingen av fritidsboliger i fjellområdene elementer av overordnet planlegging, og er som en fysisk utvikling ikke et eksempel på Brox', poeng om umuligheten av samfunnsplanlegging (se innledning). Så det er ikke i første rekke den fysiske og feltmessige utviklingen av fritidsboliger som overrasker fra et planperspektiv - til en viss grad var denne allerede projisert i Fjellbygd og feriefjell og utredninger og komitearbeid på 6o-tallet og framover et par tiår. Men, det er en feilslutning å hevde at utviklingen ikke er overraskende på et annet nivå enn det fysiske. Fritidsboligutviklingen har utviklet seg på måter som ikke var forutsett på 60-, 70- og til dels 8o-tallet - som samfunnsfenomen og som et spørsmål om hvordan en stor husholdningsgruppe i samfunnet lever sine liv.

På husholdningsnivå er dette foran foreslått begrepsfestet som flerhushjemmet, en organisering av husholdninger som «lever på» hva vi vel må kunne kalle en hypermobilitet. I etterkrigstiden har husholdningene fått ekspandert sin kontroll over rom og tid (ikke minst gjennom fleksitidordninger), som også er tatt ut som nye former for å bo, for bolig og for arbeid. Nettopp flerhushjemmet har vist sin fleksibilitet i covid-19perioden med utstrakt bruk av hjemmekontoret, og fritidsbolig er her en nøkkelfaktor (Arnesen et al., 2012; Cruickshank et al., 2009; Ellingsen \& Hidle, 2013; Hidle \& Ellingsen, 2011).

Bauman (2013) har benyttet begrepet «liquid modernity» eller «flytende modernitet» for å beskrive blant annet nye bo- og boligformer. Flytende modernitet er preget av dynamiske sosiale strukturer - nettverkskapital som utvikles, oppsøkes og oppløses. Poenget i denne sammenheng er at husholdningene veksler mellom forskjellige romlige og temporære steder av bo og bolig. Prosessen, mener Bauman, er drevet av individualisme i en hypermobil verden der aktører bytter, skifter mellom og betjener flere 
arbeidssteder, boliger og sosiale nettverk. Mobilitet er da en forutsetning for arbeid, fritid og relasjoner, og kan endre karakter eller profil ikke bare gjennom livsløpet, men også gjennom året eller kortere eller lengre tidsperioder. Mobilitetsbetinget nettverkskapital kan ses på som et samlet uttrykk for de relasjoner og «stasjoner» som for eksempel en husholdning utvikler, herunder «stasjoner» som knytter seg til bolig og de sosiale, kulturelle og fysiske relasjoner som det å bebo støtter seg på.

Så, hvordan forstå denne utviklingen på samfunnsnivå, hvilke begreper kan benyttes? Vi mener det er dekkende å betrakte fritidsboligstrukturen i fjellområdene som en egen boligstruktur, «grønn» boligstruktur. ${ }^{13}$ Den er en parallell boligstruktur til tradisjonell boligstruktur eller «rød» boligstruktur.

Parallelliteten mellom rød og grønn boligstruktur er av tre grunnleggende typer. (1) Fysisk eller romlig ved at de gjennomgående bare unntaksvis krysser hverandre. (2) Teknisk ved at det i begge strukturer er snakk om høgstandard boliger. (3) Sosialt ved at de begge fyller husholdningens bolig- og bofunksjoner i et stadig tettere integrert bruksmønster.

Med vekt på fjellområdet kan de to boligstrukturene illustreres slik:

\section{«Rød» boligstruktur}

I figur 3 vises befolkning i tettstedene i Sør-Norge. For å gjøre kartet litt mindre overfylt, er grensen satt ved et registrert befolkningstall på 1000 for å vises på kartet. Det er til sammen 3298 slike tettsteder hvorav 280 $(8,4$ prosent) befinner seg i fjellområdet. Dette er «rød» boligstruktur.

Høyden på stolpene gir et bilde på befolkningsstørrelse i tettstedene, og tettheten av stolper avspeiler hvor befolkningsagglomerasjoner i landet befinner seg.

«Skogen» av stolper langs kysten har økt både i tetthet og høyde. Den tilsvarende utviklingen i fjellområdet har registrert en stagnert befolkningsutvikling (NOU 2020: 15). 


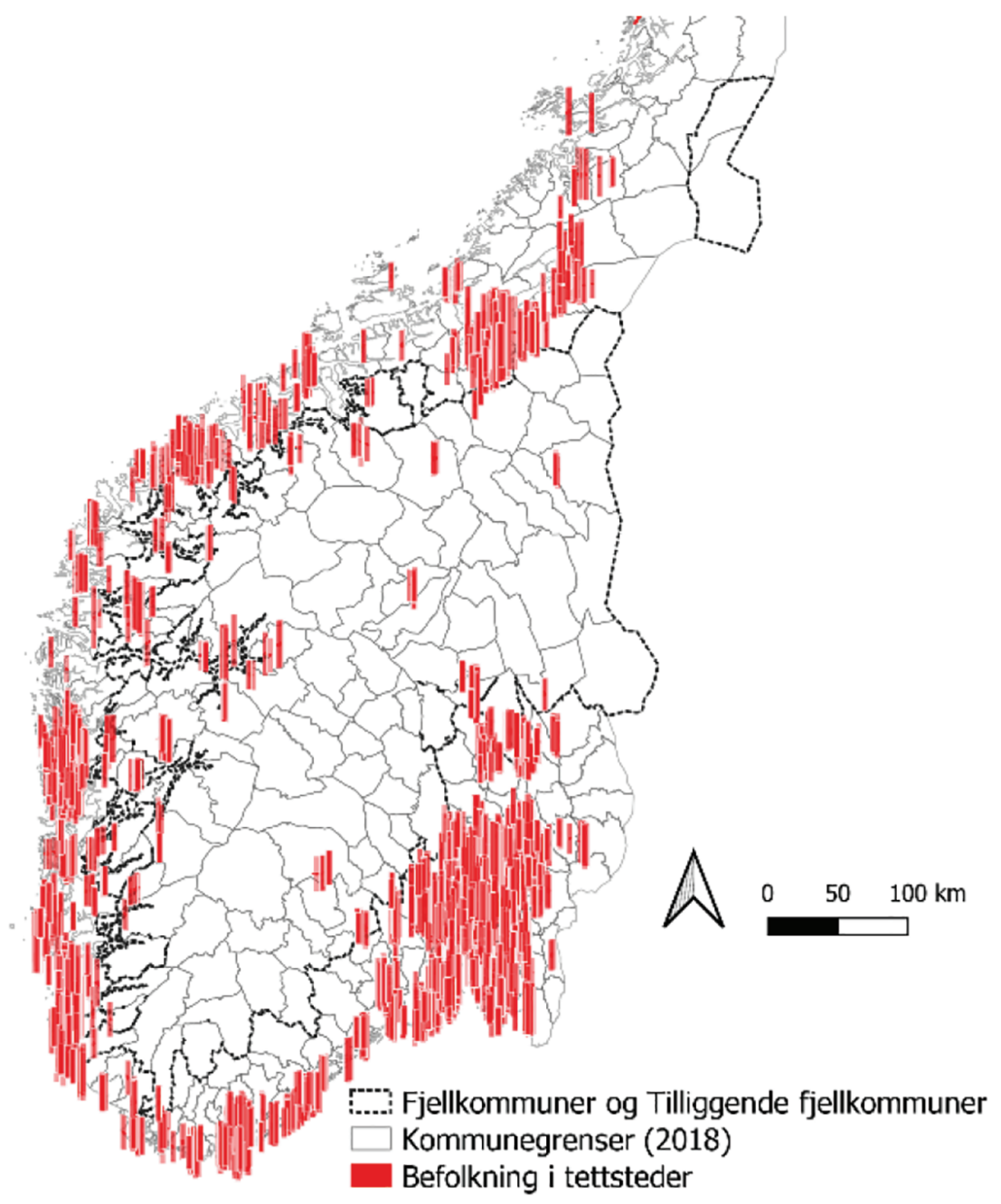

Figur 3. Tettsteder med minst 1000 heltidsboende. Kilde: SSB og Kartverket. Figur: Høgskolen i Innlandet.

\section{«Grønn» boligstruktur}

Lagt til i grønt (figur 4) er alle tettbygde fritidsbyggområder i fjellområdet som har minst 100 fritidsbygg. Sammenhengende fritidsbyggområder er ansamlinger av fritidsbygg med maksimalt 75 meter mellom ett bygg og det neste (Statistisk sentralbyrå, 2020). 
Det er til sammen vel 360 tettbygde fritidsbyggområder med minst 100 fritidsbygg, og samlet har disse cirka 150 ooo fritidsbygg. Disse er illustrert i kartet. Stolpenes lengde relativt til hverandre fordeler enheter på områdene.

I tillegg er det cirka 70 ooo fritidsbygg som ligger i så mye som 4001 fritidsbyggområder som har mindre enn 100 fritidsbygg per område. Vi kan kalle denne for «grønn» boligstruktur.

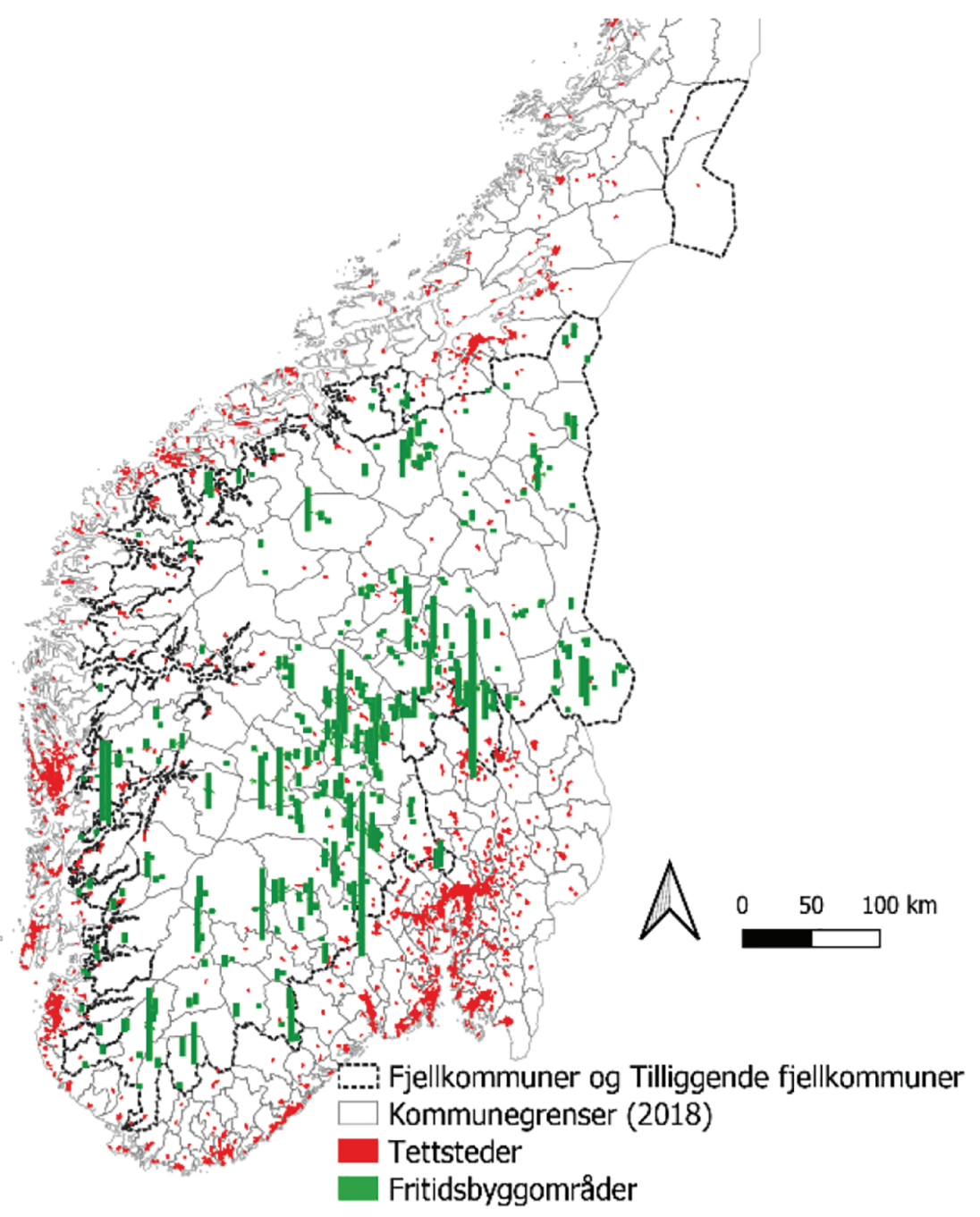

Figur 4. Sammenhengende fritidsbyggområder i fjellområdet med minst 100 fritidsbygg. Kilde: SSB og Kartverket. Figur: Høgskolen i Innlandet. 
I fjellområdet har på totusentallet grønn boligstruktur økt med vel 3500 enheter årlig (Arnesen et al., 2018) - mens det tilsvarende antall nye boliger i rød boligstruktur i samme området er om lag en tredjedel av dette. I fjellområdet er det derfor en radikalt større vekst i grønn boligstruktur enn i rød boligstruktur. I dag er det i fjellområdet så å si like mange boligenheter i grønn som i rød boligstruktur.

\section{Grønn boligstruktur som politisk rom}

Erik Brofoss formulerte engang følgende: «Byer bør bygges på landet!» (Brofoss, 1966). Sammenhengen dette ble sagt i var et Norge i endring. Argumentet her er, om ikke byer, så dukker det opp en form for (fritids-) boligstrukturer som likner på tettsteder, nettopp «på landet!».

Men det er bare knapt nok som følge av en samfunnsplan. Snarere er det en konsekvens av aktørers individuelle handlinger (myndigheter, utbyggere og husholdninger) som etter hvert manifesterer seg som tettstedsstrukturer. Det vil føre for langt i denne artikkelen å drøfte konsekvensene av dette, ut over å berøre noen hovedpunkter.

I kraft av den private kapitalopphopingen grønn boligstruktur representerer, kan den analyseres som framvoksende politiske rom i utmarka. Begrepet 'politisk rom' kan forstås som tilgang på arenaer med makt over ressurser og interesser - herunder bruk av utmarksressurser. $\AA$ utvikle et fritidsbyggområde er også å skape et politisk rom i utmark, der nye aktører (fritidsbygghusholdninger) skal formulere og fremme sine interesser i møte med landbruk, med naturverninteresser, friluftsinteresser og så videre. Det politiske rommet gir aktørene mulighet til å bestride, utfordre og påvirke måten beslutninger om interesser og bekymringer formuleres og kontrolleres. Kampen om eller i det politiske rom innebærer en brytning mellom sosiale maktforhold der aktørene benytter seg av innflytelse, legitimitet og autoritet, og der de har synlig og symbolsk komparativ fordel (Lefebvre, 1991). Aktørene kan utøve forskjellig innflytelse, legitimitet og autoritet som passer konteksten eller møtet på et bestemt tidspunkt. Det kritiske poenget her er at hvem som skaper, okkuperer og kontrollerer inngangen til forskjellige typer rom, bestemmer hvem som blir hørt og hvem som får tilgang til 
ressurser og beslutninger. Studiet av fritidsbyggområdet som politisk rom er et arbeid for framtidige analyser.

En viktig forskjell mellom rød og grønn boligstruktur, er at rød boligstruktur er innlemmet $i$ et offentligrettslig rom, mens grønn boligstruktur er et privatrettslig anliggende. Veier, plasser og liknende infrastruktur som i byer og tettsteder er offentlige rom, er i fritidsbyggområdene gjennomgående privatrettslig regulert.

Forstått som to parallelle boligstrukturer har de i dag vesentlig forskjellig plass i plansystemet, ikke minst i plan- og bygningslov-praksis. I utviklingen av rød boligstruktur vurderes boligområdenes lokalisering og utforming som sentralt element i utviklingen av lokalsamfunnet. Problemstillinger som nærhet til skole, helse- og velferdstjenester, samfunnssikkerhetstjenester, handelssentra, arbeidsplasser, nærhet til annen boligstruktur osv. - som et samlebegrep lokalisering i forhold til sivil infrastruktur - er en innarbeidet prosedyre i planprosesser når rød boligstruktur utvikles. Det er det derimot ikke når grønn boligstruktur utvikles. Nå skal ikke grønn boligstruktur utvikles etter samme formål som rød, og det gir føringer for hvilke hensyn til sivil infrastruktur som skal legges til grunn. Problemet i dag er at grønn boligstruktur sjelden vurderes i forhold til sivil infrastruktur, og i den grad det skjer, er det primært lokaløkonomi som vektlegges. Fritidsboligene går under radaren. Så, politikk og planlegging er i liten grad justert i samsvar med endringene som har foregått de siste tiårene (Skjeggedal et al., 2021). I denne sammenheng dreier det seg om grønn boligstrukturs belastning på og betydning for vare- og tjenesteetterspørsel, helse- og velferdstjenester inkludert samfunnssikkerhetstjenester.

Som framvoksende politisk rom i utmarka er grønn boligstruktur ennå i støpeskjeen hva angår hvordan politisk makt kan sluses inn i beslutningsprosesser. Det er ennå uklart hvordan den grønne boligstrukturen bidrar til å utforme eller påvirke utviklingen i utmarka, herunder hvordan den griper inn i lokal, regional og nasjonal politikk (Arnesen, 2007; Skjeggedal et al., 2021). Det er åpenbart ikke meningsfylt å tilordne det som gjerne refereres til som «hyttefolk» entydige politiske posisjoner, holdninger eller orienteringer. På samme måte som det heller ikke er meningsfylt å tilordne entydige politiske posisjoner, holdninger eller 
orienteringer til «byfolk» eller «bygdefolk». Men på samme måte som «røde tettsteder» er politiske rom, er også «grønne tettsteder» det men selve institusjonaliseringen av maktpotensialet ikke er på plass (Ringholm \& Arnesen, 2014).

Konseptuelt har vi i dag ingen klar parallell til hvordan fritidsbyggområdene skal forstås som politiske rom, inklusive hvordan deres politiske makt kan kanaliseres inn i den etablerte institusjonaliseringen av politisk påvirkning. Sigona (2015) drøfter en interessant konseptualisering av leiren som et unntaksområde, ${ }^{14}$ som et motstykke til en idealisert forestilling om borgerskap og tilhørende rettigheter - rettigheter som lokalt først og fremst utløses av status som heltidsboende. Å komme nærmere deltidsboende avslører kanskje fritidsbyggområdet som en «leir», og som paradigmatisk for stratifisering og spredning av deltakelse i politiske prosesser (bl.a. innflytelse på arealplanprosesser). Grønn boligstruktur som politisk rom representerer et sosialt og politisk terreng der rettigheter og plikter omformes, bøyes, justeres og aktiveres av og gjennom interaksjoner mellom fritidsbyggområdene og den tradisjonelle tettsteds- og bystrukturen i vertskommunene, og mellom vertskommunene og samfunnet utenfor disse hvor fritidsbolighusholdningene har sitt dagligliv.

Politiske spenningsfelt mellom grønn og rød boligstruktur, mellom deltidsboende og heltidsboende er nylig demonstrert med all tydelighet i forbindelse med covid-19-pandemien. Regjeringen innførte «hytteforbud» for å holde hyttefolket unna påskefjellet og litt til. Forbudet bunnet i en kalkyle som en rekke «hyttekommuner» målbar, nemlig at disse ikke hadde ressurser til å ta seg av «byfolk» - presumptivt oppfattet som smittebefengte husholdninger som kom til sine hytter i utmarka. Det ble vekslet ukvemsord både om hyttefolk og fra hyttefolk, både fra lokalbefolkning og til lokalbefolkning. Et av de mer utrerte overtrampene fra lokal side sto vel ansvarlig redaktør i Rjukan Arbeiderblad for, som med sin leder 14. mars 2020 slo fast at «Sjansene for at koronasmitten spres mangedobles mer enn undertegnede aner, er veldig stor», og deretter serverte følgende analyse av hyttefolket i Tinn: «Det vi ser er

14 Riktignok i en helt annen og humanitær prekær situasjon. I denne sammenhengen er det det rent konseptuelle ved analysen som adresseres. 
voksne mennesker som er ikke vant til begrensinger, og opptrer som bortskjemte og trassige umyndige. Oppførselen er ikke i tråd med hva som er til samfunnets beste.»

Men hytteforbudet var aldri fra sentralt hold begrunnet med økt smittefare, men for en uttrykt frykt fra en rekke ordførere i berørte kommuner for manglende sivil infrastruktur til å ta vare på grønn boligstruktur.

Det er ennå et stykke fram til grønn boligstruktur er oppfattet som nettopp det, en boligstruktur. Det er ennå uklart hvordan den kan bli integrert i den sivile infrastrukturen, enten det er i politisk, forvaltningsmessig, funksjonell eller økonomisk forstand (Arnesen, 2020a; Overvåg \& Skjeggedal, 2014; Skjeggedal et al., 2021). Selv i kommuner som har tunge innslag av grønn boligstruktur, finner man bare unntaksvis spor av dem i planverket ut over det mest nødtørftige som å tilvise areal for byggeformål fritidsbygg. Det finnes for tiden ikke sentral fritidsboligpolitikk ut over søkelys på arealbruk og utforming, da gjerne som enkeltbygg og felt, men behov og interesse for en slik politikk er økende.

\section{Referanser}

Arnesen, T. (2007). Involvement in outfield land use policy formation, who and why? I I. Balberg \& H. Hofstad (Red.), Authority, responsibility and justice in environmental politics (NIBR-notat 2007:112, s. 123-139). Norsk institutt for by- og regionforskning. https://hdl.handle.net/20.500.12199/2512

Arnesen, T. (2015). Utmarksnoeringer - begrep og bruk i LNFR-områder på Hardangervidda. Østlandsforskning.

Arnesen, T. (2020a, 4. mai). Meanwhile in Norway: The coronavirus crisis puts emergency preparedness in rural mountain municipalities on the agenda. Euromontana. https://www.euromontana.org/en/meanwhile-in-norwaythe-coronavirus-crisis-puts-emergency-preparedness-in-rural-mountainmunicipalities-on-the-agenda/

Arnesen, T. (2020b, 17. mars). Koronakrisen bør sette fart på utbygging av infrastruktur i hytteområder. Forskersonen. https://forskersonen.no/kronikkmeninger/koronakrisen-bor-sette-fart-pa-utbygging-av-infrastruktur-ihytteomrader/1655819

Arnesen, T. \& Bryn, A. (2020). Fritidsbygg og skoggrenser i fjellområder (Skriftserien 2-2020). Høgskolen i Innlandet. https://www.ostforsk.no/publikasjoner/ fritidsboliger-og-skoggrensen-i-fjellomrader/ 
Arnesen, T. \& Ericsson, B. (2013). Policy responses to the evolution in leisure housing: From the plain cabin to the high standard second home. The Norwegian case. I Z. Roca (Red.), Second home tourism in Europe: Lifestyle issues and policy responses (s. 285-308). Ashgate.

Arnesen, T., Overvåg, K., Gløersen, E., Schurman, C. \& Riise, Ø. (2010). Fjellområder og fjellkommuner i Sør-Norge. Definisjon, avgrensing og karakterisering (ØF-rapport 2010/o8). Østlandsforskning. https://www.ostforsk.no/ publikasjoner/fjellomrader-og-fjellkommuner-i-sor-norge-definisjon-avgrensingog-karakterisering/

Arnesen, T., Overvåg, K., Skjeggedal, T. \& Ericsson, B. (2012). Transcending orthodoxy: Leisure and the transformation of core - periphery relations. I M. Danson \& P. de Souza (Red.), Regional development in northern Europe. Peripherality, marginality and border issues in northern Europe (s. 182-195). Routledge.

Arnesen, T., Kvamme, S. \& Skjeggedal, T. (2018). Fritidsboliger og friluftsliv $i$ fiellområdene (ØF-rapport 2018/14). Østlandsforskning. https://www.ostforsk.no/ publikasjoner/fritidsboliger-og-friluftsliv-i-fjellomradene/

Arnesen, T. \& Skjeggedal, T. (2003). Rekreasjon materielle og sosiale struktur. Spekulasjoner om å bo, utmark og urbanitet. Plan, 2, 10-14.

Bauman, Z. (2013). Liquid modernity. John Wiley \& Sons.

Brofoss, E. (1966). Bosetting og lokaliseringspolitikk. Pax.

Brox, O. (2016). Samfunnsplanleggeren: Arkitekt eller doktor? Plan, 48(03-04), 74-79. https://doi-org.ezproxy1.usn.no/10.18261/ISSN1504-3045-2016-03-04-16

Cruickshank, J., Hidle, K. \& Ellingsen, W. (2009). Hyttemobilitet som samfunnslim - et innspill til norsk distriktspolitikk. UTMARK - tidsskrift for utmarksforskning, 1 .

Duschene-Lacroix, C., Schad, H., Hilti, N. \& Hugentobler, M. (2014). Multilokales Wohnen in der Schweiz - erste Einschätzungen zum Aufkommen und zu den Ausprägungen. I P. Weichhart \& P. Rumpolt (Red.), Mobil und doppelt sesshaft Studien zur residenziellen Multilokalität (s. 176-201). Institut für Geographie und Regionalforschung. http://www.academia.edu/download/47645401/Multilokales_ Wohnen_in_der_Schweiz_erst20160730-28979-qy5i8n.pdf

Duval, D. T. (2004). Mobile migrants: Travel to second homes. I C. M. Hall \& D. K. Müller (Red.), Tourism, mobility and second homes: Between elite landscape and common ground (s. 87-96). Channel View Publications.

Ellingsen, W. (2016). Rural second homes: A narrative of de-centralisation. Sociologia Ruralis, 57(2), 229-244. https://doi.org/10.1111/soru.12130

Ellingsen, W. \& Arnesen, T. (2018). Fritidsbebyggelse. Fra byggesak til stedsutvikling (ØF-notat 03/2018). Østlandsforskning. https://www.ostforsk.no/publikasjoner/ fritidsbebyggelse-fra-byggesak-til-stedsutvikling/ 
Ellingsen, W. G. \& Hidle, K. (2013). Performing home in mobility: Second homes in Norway. Tourism Geographies, 15(2), 250-267. https://doi.org/10.1080/14616688. 2011.647330

Ericsson, B. \& Flognfeldt, T. (2018a). Fritidsboligene i Sjusjøenområdet. Om eiere og bruk. (Notat Nr. 2018/o9). Østlandsforskning, Eastern Norway Research Insitute. https://www.ostforsk.no/wp-content/uploads/2018/06/201809_Fritidsboligene_i_ Sjusjoenomradet_pdf

Ericsson, B. \& Flognfeldt, T. (2018b). Fritidshusene og deres brukere (ØF-rapport 09/2018). Østlandsforskning, Eastern Norway Research Insitute. https://www. ostforsk.no/wp-content/uploads/2018/10/201809_Fritidshusene_og_deres_ brukere.pdf

Flognfeldt, T. (2004). Second homes as a part of a new rural lifestyle in Norway. I C. M. Hall \& D. K. Müller (Red.), Tourism, mobility and second homes. Between elite landscapes and common ground (s. 233-243). Channel View Publications.

Gallent, N. (2006). Second homes, community and hierarchy of dwelling. Area, 39(1), 97-106. https://doi.org/10.1080/14036096.2013.830986

Glaser, B. G. (2007). Doing formal theory. I A. Bryant \& K. Charmaz (Red.), The Sage handbook of grounded theory (s. 97-113). https://dx.doi.org/10.4135/ 9781848607941.n4

Hidle, K. \& Ellingsen, W. (2011). Hyttemobilitet som kulturfenomen. I H. J. Gansmo, T. Berker \& F. A. Jørgensen (Red.), Norske hytter i endring. Om boerekraft og behag (s. 91-106). Tapir Akademisk Forlag.

Holz, K. \& Haagensen, T. (2018). Fritidsbygg og -områder innen 4 timers kjøretid fra de største tettstedene i Norge. Geografisk analyse med status over antall fritidsbygg per 1. januar 2017 og byggeaktivitet i perioden 2012-2016 (Rapport 2018/30). SSB. https://www.ssb.no/natur-og-miljo/artikler-og-publikasjoner/_ attachment/362030?_ts $=165$ fic 81 f 88

Haagensen, T. (2019, 13. desember). Ny trend - størst vekst $i$ de store tettbygde fritidsbyggområdene. https://www.ssb.no/natur-og-miljo/artikler-ogpublikasjoner/ny-trend-storst-vekst-i-de-store-tettbygde-fritidsbyggomradene

Konsesjonsloven. (2003). Lov om konsesjon ved erverv av fast eiendom mv. (LOV2003-11-28-98). Lovdata. https://lovdata.no/lov/2003-11-28-98

Langdalen, E. (1980). Second homes in Norway - a controversial planning problem. Norsk geografisk tidsskrift - Norwegian Journal of Geography, 34(3), 139-144. https://doi.org/10.1080/00291958008552059

Langdalen, E. (1992). Fjellbygd og feriefjell 30 år etter. I M. Jones \& W. Cramer (Red.), Levekår og planlegging. Festskrift til Asbjørn Aase (s. 11-30). Tapir.

Lefebvre, H. (1991). The production of space. Blackwell Publishing. 
McArthur, D. P., Thorsen, I. \& Ubøe, J. (2014). Employment, transport infrastructure, and rural depopulation: A new spatial equilibrium model. Environment and Planning A, 46(7), 1652-1665. https://doi.org/10.1068/a46120

McHugh, K. E., Hogan, T. D. \& Happel, S. K. (1995). Multiple residence and cyclical migration: A life course perspective. The Professional Geographer, 47(3), 251-267.

McIntyre, N., Williams, D. \& McHugh, K. (2006). Multiple dwelling: Prospect and retrospect. I N. MacIntyre, D. R. Willams \& K. E. McHugh (Red.), Multiple dwelling and tourism. Negotiating place, home and identity (s. 313-322). CABI Publishing.

Miljøverndepartementet. (1977). Hytter og fritidshus [Rundskriv]. https://www. regjeringen.no/contentassets/bcbe612aefc9462abob37ofaoa8a5bb1/rundskriv1977-t-13-hytter-og-fritidshus.pdf

Müller, D. K. (2002). German second home development in Sweden. I C. C. Hall \& D. R. Willams (Red.), Tourism and migration: New relationships between production and consumption (s. 169-186). Kluwer.

Müller, D. K. \& Marjavaara, R. (2012). From second home to primary residence: Migration towards recreational properties in Sweden 1991-2005. Tijdschrift voor economische en sociale geografie, 103(1), 53-68. https://doi.org/10.1111/j.1467-9663. 2011.00674.x

NOU 1981: 21. (1981). Hytter og fritidshus. Miljøverndepartementet. https://www. nb.no/items/URN:NBN:no-nb_digibok_2013061808018?page=1

NOU 2020: 15. (2020). Det handler om Norge. Utredning om konsekvenser av demografiutfordringer i distriktene. Kommunal- og moderniseringsdepartementet. https://www.regjeringen.no/no/dokumenter/nou-2020-15/id2788079/

Overvåg, K. (2009). Second homes in eastern Norway. From marginal land to commodity [Doktorgradsavhandling, Norges teknisk-naturvitenskapelige universitet]. NTNU Open. http://hdl.handle.net/11250/265331

Overvåg, K. (2011). Second homes: Migration or circulation. Norwegian Journal of Geography, 65(3), 154-164. https://doi.org/10.1080/o0291951.2011.598237

Overvåg, K. \& Arnesen, T. (2007). Fritidsboliger og fritidseiendommer i omland til Oslo, Trondheim og Tromsø (ØF-notat 4/2007). Østlandsforskning. https://www. ostforsk.no/publikasjoner/fritidsboliger-og-fritidseiendommer-i-omland-tiloslo-trondheim-og-tromso/

Overvåg, K. \& Skjeggedal, T. (2014). Fjellkommuner i Norge: Bygdesamfunn eller verneområder? UTMARK - tidsskrift for utmarksforskning, (1-2).

Perlik, M. (2010). Leisure landscapes and urban agglomerations - disparities in the Alps. I A. Borsdorf, G. Grabherr, K. Heinrich \& J. Stötter (Red.), Challenges for mountain regions tackling complexity (s. 112-119). Böhlau Verlag. 
Quinn, B. (2004). Dwelling through multiple places: A case study of second home ownership in Ireland. I C. M. Hall \& D. K. Müller (Red.), Tourism, mobility and second homes (Kap. 8). De Gruyter. https://doi.org/10.21832/9781873150825-010

Ringholm, T. \& Arnesen, T. (2014, 10.-15. april). The democratic balance of new development initiatives in Norwegian mountain regions [Paperpresentasjon]. Sustainable Governance of Rural Areas: Changes, Challenges and Conflicts, Salamanca.

Rye, J. F. (2006). Leaving the countryside: An analysis of rural-to-urban migration and long-term capital accumulation. Acta Sociologica, 49(1), 47-65. https://doi. org/10.1177/0001699306061899

Schmied, D. (2005). Winning and losing: The changing geography of Europe's rural areas. Ashgate Publishing.

Sigona, N. (2015). Campzenship: Reimagining the camp as a social and political space. Citizenship Studies, 19(1), 1-15. https://doi.org/10.1080/13621025.2014.937643

Skjeggedal, T. \& Overvåg, K. (Red.). (2015). Fjellbygd eller feriefjell? Fagbokforlaget Vigmostad \& Bjørke.

Skjeggedal, T., Overvag, K., Arnesen, T. \& Ericsson, B. (2009). Hytteliv i endring. Plan, 41(6), 42-49. https://doi.org/10.18261/ISSN1504-3045-2009-06-11

Skjeggedal, T., Overvåg, K., Arnesen, T. \& Ericsson, B. (2015). Hytteliv i endring fra fritidsbolig til flerhushjem. I T. Skjeggedal \& K. Overvåg (Red.), Fjellbygd eller feriefjell? (s. 55-78). Fagbokforlaget Vigmostad \& Bjørke.

Skjeggedal, T., Arnesen, T. \& Overvåg, K. (2021). Hyttelivets rekreative sirkulasjon umulig å planlegge? Plan, 53(2), 10-17. https://doi.org/10.18261/issn.1504-30452021-02-03

Statistisk sentralbyrå. (2017, 1. desember). Flest nye hytter $i$ store fritidsbyggområder. https://www.ssb.no/natur-og-miljo/artikler-og-publikasjoner/flest-nye-hytter-istore-fritidsbyggomrader

Statistisk sentralbyrå. (2020). 12511: Fritidsbygg, etter høyde over havet, innenfor og utenfor tettbygd fritidsbyggområde, og størrelse på område (K) 2016-2019.

PX-Web SSB. https://www.ssb.no/statbank/table/12511/

Statistisk sentralbyrå. (2021). o8936: Vernet areal, etter statistikkvariabel, region, verneformål og år [Statistikkbanken]. https://www.ssb.no/statbank/table/o8936/ tableViewLayout2/

Strauss, A. \& Corbin, J. M. (1997). Grounded theory in practice. Sage.

Sømme, A., Langdalen, E., Einevoll, O., Aase, A., Thormodsæter, A., Ovsfedal, S., Skage, O. R. \& Sundt., H. A. (1965). Fjellbygd og feriefjell. J. W. Cappelen. 


\title{
Rettslege rammer for klimavenleg energiproduksjon i utmarka: Utfordrar klimaomsynet legitimiteten til konsesjonsregelverket?
}

\section{Katrine Broch Hauge \\ Universitetet i Oslo}

\begin{abstract}
The background for the article is the climate challenge necessitating development of renewable energy sources in the Norwegian outfields (utmark). Climate change is considered the world's leading environmental challenge and therefore also one of the greatest challenges to society. The loss of species and biodiversity is another fundamental problem, according to the UN Nature Panel IPBS. Nevertheless, climate change is somewhat absent in the context of Norwegian legislation. The article shows that climate change is relevant, however, in Norway's concession laws, reviewed in this paper. The main question is: what is the basis of legitimacy for regulations that take climate and nature into consideration? The analysis is mainly based on the doctrinal legal method and some assessments of legal politics. Various perceptions of legitimacy within a legal context are also explored. It can be argued, with regard to wind power, that projects realized in recent years suffered from a deficit of local co-determination with respect to the legislature's intentions, the explanation being that planning at a regional level is no substitute for the lack of municipal planning. In addition, from an overarching perspective, it is difficult to create a manageable legal situation for user and environmental interests in the countryside with the wide administrative discretion that appears.
\end{abstract}

Keywords: renewable energy, climate change, legitimacy, licensing, administrative discretion, outfields

Sitering: Hauge, K. B. (2021). Rettslege rammer for klimavenleg energiproduksjon i utmarka: Utfordrar klimaomsynet legitimiteten til konsesjonsregelverket? I F. Flemsæter \& B. E. Flø (Red.), Utmark i endring (Kap. 6, s. 151-189). Cappelen Damm Akademisk. https://doi.org/10.23865/noasp.151.ch6 Lisens: CC BY-NC-ND 4.0 


\section{Innleiing}

Sentrale styringsverktøy for å avvega klima- og miljøomsyn innanfor etablering av vasskraft og vindkraftverk er i dag konsesjonsreglane i vassdragsreguleringslova, vassressurslova og energilova. Tradisjonelt er konsesjonsreglar rekna som eit tenleg verkemiddel i miljø- og naturressurspolitikken (Backer, 2019, s. 38; Winge, 2013, s. 57, 65). Reglane gir vide fullmakter til forvaltninga, men dei kan ikkje sjåast isolert frå andre styringsmekanismar om ein skal få eit godt bilete av korleis ulike interesser og verdiar blir synleggjort og verdsett i konsesjonsvurderingane.

\section{Oversikt og problemstillingar}

Ambisjonen for dette kapittelet er å gi ei viss oversikt over aktuelle problemstillingar. Målet er altså meir å peika på spørsmål enn å gi dei inngåande drøftingane. Overordna problemstilling i kapittelet er om inntoget av klimaomsynet i det rettslege puslespelet konsesjonsreglane er del av, har kome med ei slik tyngd at det kan slå sprekker i biletet av opne konsesjonsreglar som tenlege og nærast sjølvsagte verkemiddel på området. Det grunnleggjande dilemmaet rettsreglane er meint å handtera, er produksjon av fornybar energi versus kostnader i form av naturtap og andre negative påverknader på lokale tilhøve. Eit hovudspørsmål er dermed om opne vide fullmakter til forvaltninga framleis er den beste metoden for å sikra legitimitet kring avvegingane av dei grunnleggjande klima- og miljøomsyna som står på spel i desse sakene. Spørsmålet er viktig for å kunna seia noko om kor føreseieleg rettssituasjonen for brukar- og miljøinteresser i utmarka er i dag. Gode og tenlege reglar for sakshandsaminga er verkemiddel for å sikre medverknad, kunnskapsgrunnlag og avveging. Slik er desse også avgjerande for om saksgangen blir oppfatta som føreseieleg og legitim. Likevel prøver eg her å setje dei materielle rammene for vedtaka i sentrum i drøftinga av kva som gir reglane legitimitet. Det er trass alt desse som først og fremst styrer kva vurderingar forvaltninga skal gjere.

Det overordna temaet er altså kva som gir ein rettsregel, som skal avvega kryssande energi/klima og naturomsyn legitimitet. Eller med 
andre ord når er det du som turgåar, bonde på sauesank eller lukkeleg sommarturist kan akseptera at naturen rundt deg blir endra? Det vi kan spørja om for å få ein peikepinn på dette, er om rettsreglane er utforma slik at dei gir grunnlag for ein føreseieleg, rettferdig og demokratisk forankra rettsbruksprosess (Mæhle \& Aarli, 2018, s. 422). Vi kan omtala desse momenta som legitimitetsmarkørar. Ei avgjerd som ikkje fell i god jord hjå einskildinteresser, kan likevel oppfattast som rettferdig. Føresetnaden er at den generelle norma synest rettferdig og rasjonell (Bernt, 2004, s. 62). Om rettsstaten skal fungera som samfunnsprosjekt, så er det nettopp desse forventningane til kvalitet i innhald rettsreglane og handhevinga retten må innfri (Bernt, 2004, s. 62). I tillegg til å handheva jussen i samsvar med den juridiske metoden kan også det juridiske fellesskapet vera med å sikra at retten blir oppfatta som legitim gjennom deltaking i diskusjonen om korleis retten kan utviklast i samspel med samfunnet (Mæhle \& Aarli, 2018, s. 428). Kapittelet kan også lesast som forsøk på å identifisera slike utviklingsmoglegheiter.

La oss sjå på den massive motstanden mot etablering av einskilde vindkraftverk, og reaksjonane mot forsøket frå styresmaktene på å laga ei nasjonal ramme for vindkraft. Er motstanden av ein slik art at den er eigna til å svekkja den allmenne legitimiteten til konsesjonssystemet? Mangel på tillit til forvaltninga og til handteringa av motstridande interesser når det gjeld kraftutbygging, er ikkje noko nytt tema (Backer, 1984, s. 165-193). Klimaomsynet på den eine sida, og kunnskap om trongen for å verna om naturgrunnlaget på den andre, gjer det likevel særleg aktuelt med ei drøfting av konsesjonsreglane. I dette kapitlet tek eg ikkje opp dei særlege spørsmåla som reiser seg når eit konsesjonstiltak støyter mot samiske interesser (sjå for eksempel Høgsterett 2021, HR-20211975-S).

Sidan eg undersøker kva plass klimaomsynet har i avvegingane etter konsesjonsreglane, er det også grunn til å sjå på kva lovgivar har sagt om klimaomsynet og arealplanlegging. Denne delen av temaet har fått ny aktualitet etter vedtaket på Stortinget hausten 2020 (Innst. 101 S (2021-21 Vindkraft på land). Kort sagt har Stortinget bedt regjeringa koma med eit framlegg for igjen å innlemma planlegging av vindkraftverk i den alminnelege kommunale arealplanlegginga. Utviklinga kan naturleg nok lesast 
som eit svar frå dei folkevalde på den nemnde motstanden mot etablering av vindkraftverk.

I det vidare skisserer eg nokre sentrale føresetnader for drøftinga. Eg ser først på utvalde internasjonale plikter, norsk klimapolitikk- og rett og einskilde utgangspunkt som styrer vern om naturmiljøet. Deretter diskuterer eg tilhøvet til plan- og bygningslova og anna rammestyring. Ei underproblemstilling her er korleis forvaltningssystemet i vassforskrifta kan påverka kva vekt klimaomsynet kan få i saker som gjeld konsesjonar til nye vasskraftverk. Eg går så vidare med drøftinga av relevans og vekt på klimaomsynet i konsesjonslovene. Etter dette seier eg noko om tilhøvet mellom klimaomsynet og naturmangfaldlova. Heilt kort peikar eg også på dei ulike rammevilkåra for verdiflyt frå vasskraft og vindkraftetableringar. Til slutt vil eg koma med nokre konklusjonar og refleksjonar med omsyn til handteringa av klimaomsynet innanfor konsesjonsreglane i lys av legitimitetsmarkørane.

\section{Føresetnader for drøftinga - frå internasjonale plikter til norsk klimapolitikk}

I diskusjonen av kva plass klimaomsynet har i konsesjonsreglane, er det grunn til å peika på nokre energi- og klimapolitiske haldepunkt. Eg presenterer desse for å visa noko av konteksten skjønnsutøving etter konsesjonslovene skjer innanfor i dag. Av omsyn til samanhengen peikar eg også på einskilde rettslege utgangspunkt for å handtera klimaomsynet innleiingsvis. Frå klimapanelet til FN går det fram at dersom utsleppa ikkje blir kraftig redusert, så risikerer vi ei gjennomsnittleg global oppvarming på mellom 3,7 og 4,8 grader innan 2100 (Klima- og miljødepartementet, 2014, avsnitt 2.1). Risikoen kan reduserast, delvis gjennom å tilpassa oss dei klimaendringane som kjem, men også ved å redusera globale utslepp. Med det kjem vi til temaet auka produksjon av fornybar energi. Auka produksjon av fornybar energi er i Noreg eit krevjande tema både politisk og juridisk. Ei årsak er at elektrisitet allereie har ei viktig rolle i det norske energisystemet. Norsk energi- og klimapolitikk kan heller ikkje sjåast lausrive frå utviklinga i EU. Gjennom EØS-avtalen 
får reguleringar i EU ein direkte påverknad både på energi- og klimapolitikk, og som vi skal sjå, også på våre rettslege rammeverk for energiog klimapolitikken. I norsk politikk finn vi blant dei prioriterte områda både satsing på lønsam utbygging av fornybar energi og næringsutvikling og verdiskaping gjennom effektiv bruk av fornybarressursar (Olje- og energidepartementet, 2015, avsnitt 1.1). Denne lina er ytterlegare framheva i den nye energimeldinga (Olje- og energidepartementet, 2021, særleg avsnitt 3). Regjeringa peikar også i den nye klimaplanen på at skal vi nå klimamåla, så må fleire sektorar elektrifiserast (Klima- og miljøverndepartementet, 2020, s. 18).

Den sentrale internasjonale avtalen for å jobba mot klimaendringane er Parisavtalen, ratifisert av Noreg 22. april 2016. Etter avtalen er målet å halde den globale oppvarminga under $2{ }^{\circ} \mathrm{C}$ over før-industrielt nivå. I Noreg har vi lovfesta pliktene våre etter Parisavtalen i klimalova (Klimalova, 2017). Klimalova skal fremja gjennomføring av klimamålet som del av omstillinga til eit lågutsleppssamfunn i Noreg i 2050. Verkeområdet til lova er «de utslipp og opptak av klimagasser som omfattes av Norges første nasjonalt fastsatte bidrag under Parisavtalen ...», jf. $\$ 2$ i lova. Kva rolle produksjon av fornybar energi i Noreg skal spela på vegen mot eit lågutsleppssamfunn, seier lova likevel ikkje noko direkte om.

Stortinget gjekk den 17. juni 2019 inn for ei felles løysing for gjennomføring av klimatiltak med EU. Fellesløysinga har tre grunnpilarar. Vi held fram med ein felles kvotemarknad, som vi har hatt sidan 2008. Det reviderte kvotedirektivet blir på vanleg måte ein del av EØSavtalen. Talet på kvotar som er tilgjengelege, blir gradvis redusert, og skal i 2030 vera 43 prosent lågare enn 2005-utsleppa frå sektorane som er omfatta. Nettopp kvoteplikt er eit hovudgrep i europeisk og norsk politikk. Eit anna viktig grep er $\mathrm{CO}_{2}$-avgift. Med fellesløysinga vil også rettsreglar som gjeld ikkje-kvotepliktig sektor, bli gjort gjeldande. Den tredje grunnpilaren er regelverket om skog og arealbruk. Regelverket set krav om at det skal vera netto-null utslepp frå skog og andre areal. Eg går ikkje nærare inn på detaljane i regelverket her. (For ei oversikt over EUs klimarett og Norges klimaavtale med EU sjå Kroepelin og Bugge, 2021.) 


\section{Grunnlova $\$ 112$ til vern om både klima og natur}

Både klima og natur er omsyn som har eit vern på eit juridisk overordna nivå i Grunnlova $\$$ 112. Her skal eg berre peika på einskilde utgangspunkt for forståinga av Grl $\$ 112$. Etter første ledd første punktum er det slik at alle har rett til eit «helsesamt miljø og ein natur der produksjonsevna og mangfaldet blir haldne ved lag». I første ledd andre punktum er det understreka at naturressursane skal forvaltast i eit langsiktig perspektiv, som også tryggjar retten for komande generasjonar. Det siste er ikkje minst viktig i klimasamanheng. Etter klimadommen er det ikkje tvilsamt at Grunnlova $\$ 112$ også femner om klimaomsyn (Høgsterett, 2020, avsnitt 147). Grunnlova $\$ 112$ andre ledd gir uttrykk for at alle borgarar i Noreg har rett på tilgang til kunnskap om naturmiljøet, og om verknader av planlagde og iverksette inngrep i naturen, for at ein skal kunna tryggja den materielle retten til eit reint miljø. Tredje ledd i grunnlovsføresegna regulerer plikta staten har til positivt å setja i verk tiltak som kan gjennomføra rettane (målsetjingane) sett ned i første og andre ledd i Grunnlova $₫ 112$.

Eit viktig spørsmål har vore om Grl $\$ 112$ verkeleg gir uttrykk for ein «rett»? I klimadommen blir det lagt til grunn at pliktene for staten etter Grl $\$ 112$ strekkjer seg lenger enn rettane individ kan fremja med grunnlag i $\$ 112$ (Høgsterett, 2020, avsnitt 91). Viktig å få med seg er det likevel at det i Høgsterett er semje om at Grl $\$ 112$ ikkje berre er ei rein prinsipperklæring (Høgsterett, 2020, avsnitt 144). Utfordringa er sjølvsagt kor langt domstolane skal kunna overprøva forvaltninga med grunnlag i Grl $\$$ 112. I saka som var oppe til Høgsterett, vart det lagt til grunn at vedtaket i realiteten var treft av Stortinget («... eit vedtak som på avgjerande vis byggjer på samtykke frå Stortinget») (Høgsterett, 2020, avsnitt 81). Dermed kom spørsmål om maktfordeling på spissen. Kor langt skal domstolane gripa inn når dei folkevalde har sagt sitt om saka? For tilfella der dette er utgangspunktet for domstolsprøvinga, seier Høgsterett at Grl $₫ 112$ berre er som ein tryggingsventil å rekna. Høgsterett understrekar tilnærminga ved å syna til at terskelen fylgjeleg er «svært høg» for spørsmål som Stortinget har teke stilling til (Høgsterett, 2020, avsnitt 81). For forvaltningsvedtak som Stortinget ikkje har vore involvert i er Grl $\$ 112$ relevant for lovtolkinga og eit tvunge omsyn i 
skjønnsutøvinga (Høgsterett, 2020, avsnitt 145). Særleg det siste er jo eit heilt sentralt poeng for temaet i artikkelen her som er kjenneteikna av breie skjønnsfullmakter til forvaltninga. For forvaltningsvedtak som Stortinget ikkje har vore involvert i, er det dessutan verdt å merka seg at Høgsterett uttrykkeleg sa at dei ikkje gjekk inn på spørsmålet om kor inngåande slik vedtak skal prøvast.

I klimasøksmålet var eit viktig spørsmål om verknadene av opning for petroleumsverksemd i eit bestemt område var for dårleg utgreidde. Høgsterett presiserer at det ikkje er same grunn for å vera tilbakehalden i om organet har gjort dei avvegingane som $\mathrm{Grl} \$ 112$ tredje ledd jf. første ledd krev (Høgsterett, 2020, avsnitt 182). I prøvinga av sakshandsaminga skal altså ikkje domstolane vera tilbakehaldne (Backer, 2021, avsnitt 4). Høgsterett framhevar også at Grl $\$ 112$ andre ledd set eit kvalitetskrav til sakshandsaminga (Høgsterett, 2020, avsnitt 183). I tillegg uttrykkjer Høgsterett eit krav til sakshandsaminga som synest som eit proporsjonalitetskrav. Kravet rettar seg både mot sakshandsaminga i forvaltninga, og mot prøvinga av sakshandsaminga i domstolane. Konkret seier Høgsterett at: «Di større konsekvensar eit vedtak har, di strengare krav må det stillast til avklaringa av konsekvensane. Tilsvarande må domstolsprøvinga av sakshandsaminga blir meir inngåande di større konsekvensar tiltaket har». Korleis konsekvensar skal vurderast, seier likevel ikkje Høgsterett noko om. Heilt klart må det likevel vera at både natur- og klimaomsyn er relevante også i denne vurderinga. Eg vil koma attende til Grl $\$ 112$ og klimasøksmålet der dommen synest å klargjera eller endra rettstilstanden for spørsmål som fell innanfor temaet i kapittelet.

\section{Internasjonale plikter til vern om naturgrunnlaget - og klimaet}

Det er ikkje berre omsynet til klimaet som er ivareteke på eit overordna internasjonalt nivå. Også naturgrunnlaget er verna gjennom ulike slag internasjonalt bindande avtaler. IPBES-rapporten frå FN sitt naturpanel som kom 6. mai 2019, understrekar alvoret for naturen (IPBES, 2019). Sentral i dag er FN-konvensjonen om biologisk mangfald frå 1992. Konvensjonen gir statane omfattande og generelle plikter til å verna om naturen 
(Bugge, 2019, s. 81). Viktige er også Den europeiske landskapskonvensjonen, Bernkonvensjonen (europeisk konvensjon om vern av ville planter og dyr og deira naturlege leveområde) og Ramsarkonvensjonen (våtmarkskonvensjonen). Døme på at også EØS-retten er viktig for naturvernet, er reglane om konsekvensutgreiingar, og for vassmiljøet, som vi snart skal sjå, vannrammedirektivet (direktiv 2011/92, seinare endra ved direktiv 2014/52, og direktiv 2001/42 og direktiv 2000/60). Andre meir allmenne EØS-rettslege krav til sakshandsaminga går eg ikkje inn på i det vidare. Ei viktig presisering er det at EØS-rettslege reglane om konsekvensutgreiingar set krav til å gjera greie for klima- og miljøomsyn både på over ordna nivå og tiltaksnivå. Sistnemnde gav også grunnlag for ein dissens i klimasøksmålet i Høgsterett. Mindretalet fann at sakshandsaminga ikkje tok tilfredsstillande omsyn til å gjera greie for klimaomsynet på opningstidspunktet. Tilnærminga til mindretalet synest å ha gode argument i rettskjeldene på området. Det å skyta ut utgreiinga av klimaverknadene nærare konsesjonstidspunktet synest $\mathrm{i}$ alle høve vanskeleg å sameine med intensjonen med plandirektivet (Høgsterett, 2020, avsnitt 269; Arnesen, 2021, s. 2-3; Bjørnebye, 2021, s. 169). I same retning trekkjer utsegner om at konsekvensutgreiing på tiltaksnivå ikkje kan koma til erstatning for konsekvensutgreiingar på plannivå (EU-domstolen, C-671/16 avsnitt 61 og 65). Det er dessutan viktig å ha med seg at klimaendringane sterkt forverrar situasjonen med omsyn til for eksempel kor mange artar som vil vera utryddingstrua, og øydelegging av økosystem. $\AA$ arbeida mot klimaendringane er altså også avgjerande av omsyn til naturgrunnlaget (IPBES, Summary for policymakers, 2019, s. 13).

\section{Tilhøvet til plan- og bygningslova og anna rammestyring}

Eg vil no undersøka korleis tilhøvet til arealplanar, eller anna planlegging, påverkar kva relevans og vekt klimaomsynet har i konsesjonsregelverket. Samanhengen med anna arealforvaltning, og særleg tilhøvet til kommunen som arealforvaltningsaktør, kan påverka i kva grad vedtak treft med heimel i konsesjonsreglane blir oppfatta som legitime. Det siste spørsmålet kjem eg tilbake til avslutningsvis i kapittelet. 


\section{Konsesjonslovene og plan- og bygningslova}

Det kommunale sjølvstyret som verdi er i dag teikna ned i Grunnlova $\S 49$. Ei viktig oppgåve for kommunen er nettopp å driva samfunns- og arealplanlegging. Det kan dessutan vera ei spenning mellom verdiane i Grl $\$ 112$ og Grl $\$ 49$. Kommunalt sjølvstyre føreset at kommunane må ha eit handlerom med fleire alternativ, medan omsynet til naturen på den andre sida kan tilseia at visse interesser må ha ei særleg prioritering og gjennomslag både ved planlegging og i einskildvedtak (Fauchald \& Myklebust, 2019, s. 201).

Som vi skal sjå, er særlege «køyrereglar» for ansvarsdelinga mellom sektorstyresmaktene og kommunane innanfor arealforvaltninga lovfesta i plan- og bygningslova (pbl.). Desse syner at det alminnelege utgangspunktet om kommunen som sentral aktør i arealforvaltninga lenge har hatt lite gjennomslag på området for energiforvaltninga. Med bakgrunn i motstand mot vindkraft, og mykje debatt landet rundt, har Stortinget, som nemnt innleiingsvis, bedt regjeringa koma med eit framlegg som igjen integrerer produksjon av vindkraft i plan- og bygningslova (Innst. $101 \mathrm{~S}$ (2021-21 Vindkraft på land).

Miljøomsyn og berekraftig utvikling er eit sentralt formål med planog bygningslova jf. $\$ 1-1$. Etter vanleg språkleg forståing i dag vil omgrepet «bærekraftig utvikling» også omfatta klimaomsynet. Ei slik forståing er i godt samsvar med at klimaproblemet er omtala som den første utfordringa om «[e]nkelte hovedproblemstillinger» i proposisjonen til lova (Miljøverndepartementet, 2007, s. 26).

Lovgivar har uttrykt at pbl. \$ 3-1 nemner dei «... viktigste hensynene som skal ivaretas med planlegging etter loven, og gjør det tydeligere hva loven skal være et virkemiddel for å oppnå, og hva som er de viktigste samfunnsoppgaver loven skal bidra til å løse. Uttrykkene som er valgt skal forstås i vid betydning, og er heller ikke en uttømmende liste over relevante formål og hensyn i forståelsen av loven» (Miljøverndepartementet, 2007, s. 179). Lova nemner klimaomsynet klarast i $\$$ 3-1 bokstav g, som seier at ein gjennom planarbeid skal ta omsyn til klimaet gjennom reduksjon av klimagassutslepp og tilpassing til forventa klimaendringar, under dette løysingar for energiforsyning, areal og transport. Ordlyden i \$3-1 bokstav g vart utvida så seint som i 2019 av pedagogiske grunnar. Ein 
rekna reduksjon av klimagassutslepp og tilpassinga til klimaendringar som relevante omsyn tidlegare også, men med lovendringa går dette direkte fram av lovteksten. (Kommunal- og moderniseringsdepartementet, 2018, s. 14; for meir allment om plan- og bygningslova og klimaspørsmålet sjå Holth, 2021.)

Sentralt i spørsmålet om bruk av areal til produksjon av fornybar energi, og spørsmålet om kva plass klimaomsynet har i arealplanlegginga, er også $₫$ 3-1 første ledd bokstav b. Her heiter det at planar skal «sikre jordressursene, kvaliteter i landskapet og vern av verdifulle landskap og kulturmiljøer». Etter proposisjonen er eit hovudformål med planlegging å fremja balanse mellom det økologiske, økonomiske, sosiale, helse- og kulturmål og verdiar. Same stad finn ein også uttrykt at i berekraftig utvikling ligg eit mål om rettferd mellom oss som lever i dag, og framtidige generasjonar (Miljøverndepartementet, 2007, s. 179). Intensjonen til lovgivar var at ein skulle få til å ta desse omsyna til for eksempel jordvern, landskap, kulturverdiar og natur gjennom «helheten i planleggingen».

I spørsmål om eit areal er aktuelt for utbygging av vind- eller vasskraftverk, har kommunen som planstyresmakt til trass for desse uttrykte ambisjonane lenge hatt ei redusert rolle i plansystemet. Og det er jo nettopp den norske utmarka, nokon sitt turområde eller kanskje beitemark, som til no har vore ressursgrunnlaget for slike utbyggingar.

Etter pbl. $\$ 1-3$ andre ledd, jf. energilova $\$ 3$-1, gjeld berre reglane om kart i kapittel 2 og krava til konsekvensutgreiinga i kapittel 14, for omformingsanlegg og overføringsleidningar. Unntaket gjeld overføringsanlegg bygt med heimel i anleggskonsesjon, jf. energilova $\$$ 3-1 første ledd (Winge, 2013, s. 389 flg.). Nettanlegg som har områdekonsesjon etter energilova, $\$$ 3-2 er ikkje omfatta av unntaket (Miljøverndepartementet, 2007, s. 249). Dette unntaket gjeld altså ikkje for produksjonsanlegg, som er temaet her (Miljøverndepartementet, 2007, s. 249).

Alle kommunar skal i utgangspunktet ha rettsleg bindande arealplanar for heile arealet i kommunen, jf. pbl. \$11-5. Eit areal der eit vindkraftverk er under planlegging, kan dermed typisk vera omfatta av ein arealplan. Er det eit utmarksareal, er det gjerne merka som LNFR-område, jf. pbl. $\$ 11-7 \mathrm{nr}$. 5. For at etablering av vindkraftverk skal koma i samsvar med dei kommunale arealplanane i eit LNFR-område, er dermed omregulering 
eller dispensasjon, jf. $\ 19-2$, frå plan naudsynt (Miljøverndepartementet, 2007, s. 41-42).

I førearbeida er uttrykksforma at kommunen «kan velje» å omregulere eller gi dispensasjon, valt. Uttrykksforma er vanskeleg å forstå om ein ikkje ser vidare på unntaksreglane vi har i dag for energisektoren, og korleis bruk av statleg plan er «normalisert» som styringsmiddel, jf. pbl. $\$ 6-4$ tredje ledd. Så langt har kommunen likevel framleis innverknad, og moglegheit for å prioritere mellom bruk som kan vera klimavenleg, anna bruk og vern om naturgrunnlaget, også ved etablering av vindkraftverk eller vasskraftverk.

Ei utfordring, sett frå ståstaden til kommunen og kanskje også dei lokale utmarksbrukarane, er altså at staten har tilgjengeleg verkemiddel som kan overstyra det kommunale planarbeidet. Etter plan- og bygningslova $\$$ 6-4 tredje ledd kan departementet (Olje- og energidepartementet, jf. forskrift av 26. juni 2009) bestemma at «endeleg konsesjon» til kraftproduksjonsanlegg etter energilova, vassressurslova og vassdragsreguleringslova skal ha verknad som statleg arealplan (Winge, 2013, s. 394 flg.). Eit vedtak om at konsesjon skal ha verknad som statleg arealplan, kan dessutan verken påklagast eller møtast med motsegn, jf. pbl. §6-4 tredje ledd andre punktum.

Bruk av statleg arealplan er ei unntaksordning i plansystemet (Miljøverndepartementet, 2007, s. 198). Motivet bak føresegna er å unngå at det blir sett i gang kommunale planprosessar i strid med gitte konsesjonar for energiproduksjonsanlegg. Det er også sagt at føresegna kan vera aktuell å bruka der det er gitt konsesjon, men kommunen likevel ikkje ynskjer å regulere i samsvar med konsesjonen eller å gi naudsynt dispensasjon frå arealplan (Miljøverndepartementet, 2007, s. 198). Blir statleg plan vedteken, går den føre ein arealplan med eventuelle motstridande arealformål, jf. plan- og bygningslova $\$ 1-5$ andre ledd. Isolert kan ein sjå det slik at ordninga på ein effektiv måte er eigna til å fremja nettopp klimaomsynet gjennom tilrettelegging for fornybar energi. Om ordninga på den andre sida er eigna til å sikra dei gode avvegingane mellom brukarinteresser, miljøinteresser og klimaomsyn på ein tillitvekkjande måte, er eit meir ope spørsmål.

Isolert synest kompetansen til å gjera konsesjon gjeldande som statleg plan seg uavhengig av dei alminnelege vilkåra for å vedta statleg plan i 
\$ 6-4 første ledd, men her er det nok rom for tolkingstvil. Vilkåra for å nytta statleg arealplan er i $₫ 6-4$ første angitt å vera «[n]år gjennomføringen av viktige statlige eller regionale utbyggings-, anleggs- eller vernetiltak gjør det nødvendig, eller når andre samfunnsmessige hensyn tilsier det ...» Til samanlikning er det $i$ andre ledd i $₫ 6-4$ nettopp presisert at vilkåra i første ledd også gjeld når departementet sjølv vil vedta statleg arealplan. Andre har hevda at dei alminnelege vilkåra i første ledd nok også må vera oppfylt ved bruk av kompetansen i $\$ 6-4$ tredje ledd (Fauchald, 2020, s. 16 og Fauchald, 2021, s. 609). Ut frå ordlyden og strukturen i $\$ 6-4$ kan ei anna forståing vera at vilkåra i første ledd nettopp $i k k j e$ gjeld for desse konsesjonssakene. Etter mi oppfatning kan dei uttalte formåla som er å unngå kommunale planprossesar i strid med gitt konsesjon eller unngå fastlåste situasjonar der kommunen ikkje vil omregulere eller dispensere frå også tala for ei slik forståing (Miljøverndepartementet, 2007, s. 198). I praksis vil ein likevel gjerne finna at vilkåra i $\$ 6-4$ første ledd er oppfylt i saker der det er gitt konsesjon etter dei nemnde lovene (Fauchald, 2020). I dei fleste tilfelle vil jo nettopp dei konsesjonsgitte tiltak vere eigna til å falle inn under vilkåra i første ledd. Etter førearbeida er det jo dessutan tale om «en vid skjønnsmessig adgang for staten til å utarbeide statlig plan» (Miljøverndepartementet, 2007, s. 198).

For å handtera utfordringar mellom prioriteringar på kommunalt og statleg nivå er motsegn («innsigelse») det alminnelege verkemiddelet, jf. pbl. $\$ \$$ 5-4 til 5-6. Reglane om motsegn i plan- og bygningslova gjeld så langt dei passar, for konsesjon etter energilova $\$$ 3-1 jf. energilova $\$$ 2-1 sjuande ledd, vassressurslova $₫ 24$ tredje ledd og vassdragsreguleringslova $\$ 12$ andre ledd. For at verkemiddelet motsegn skal vera effektivt, må det finnast styringssignal som statlege planretningsliner, regionale planar eller anna som kan gi uttrykk for kva som er rekna som nasjonale eller vesentlege regionale prioriteringar, jf. pbl. \$ 5-4 første jf. femte ledd (Klima- og miljødepartementet, 2017). Kva som ligg i at reglane om motsegn gjeld «så langt dei passar», er heller ikkje heilt godt å seia. Dynamikk og saksgang vil vera ganske ulik frå situasjonar der statleg overordna organ gir motsegn mot ein t.d. kommunal plan for å sikra interesser av nasjonal verdi. Motsegn-instituttet må altså tilpassast konsesjonsprosessen. I førearbeida er det skissert at motsegn bør varslast når saka er på 
høyring (Miljøverndepartementet, 2007, s. 248). Sjølv om det kan vera uklart kor langt reglane passar, oppfattar eg det slik at reglane medverkar til å sikra at ei større breidde av omsyn blir ivareteken også i konsesjonssakene.

Etter kvart som betre kunnskap om kva type naturområde som ikkje bør byggjast ned av klimaomsyn, veks fram, eller eventuelt eksisterande utmarksbruk, som blir oppfatta som klimavenleg og dermed ikkje bør hindrast, kan vera omsyn som er eigna å ta med i overordna retningsliner (sml. Olje- og energidepartementet, 2019, s. 67-68). Visse føringar på eit heilt overordna nivå finst alt i SPR for klima og energitilpassing (Kommunal og moderniseringsdepartementet, 2018). Kanskje kunne det å utforma noko meir konkrete retningsliner, etter modell av SPR for strandsonevernet, jf. pbl. $\$ 6-2$, for å sikra både klimaomsynet og andre naturverdiar i energisaker, vera ein alternativ veg å gå om styresmaktene ville ha ei sterkare styring av avvegingane av desse omsyna, utan at ein heilt koplar av det lokale arealforvaltningsnivåt (sml. Kommunalog moderniseringsdepartementet, 2021, SPR). I ny stortingsmelding om vindkraft er det også uttalt at ein ynskjer at avvegingane i konsesjonssaker skal bli meir transparente (Olje- og energidepartementet, 2019, s. 35-36). Samtidig vil det nok ganske sikkert by på utfordringar om ein søker å koma med meir konkrete prioriteringar på eit slikt overordna nivå. Til illustrasjon kan nemnast at Stortinget stemde ned forslag om å laga eit forbod mot nedbygging av myrområde handsaminga av vindkraftmeldinga hausten 2020 (Stortinget, 2020, voteringsoversikt). I førearbeida er det også sagt at ein ikkje legg opp til mekling hjå anna forvaltningsorgan, slik opplegget elles er etter plan- og bygningslova jf. $\$$ 5-6 første ledd første punktum i motsegn-saker. Grunngivnaden for denne løysinga byggjer på at konsesjonsstyresmakta skal gjera ei heilskapleg avveging av alle relevante omsyn av lokal, regional og nasjonal karakter (Miljøverndepartementet, 2007, s. 248). Om ei motsegn ikkje får medhald, heilt eller delvis, så kan konsesjonsstyresmaktene likevel gi konsesjon. Motsegna vil da ha den verknaden at konsesjonsvedtaket ikkje blir endeleg (Miljøverndepartementet, 2007, s. 42). Gjeld motsegna ein konsesjon etter energilova og NVE er vedtaksorgan, må dermed vedtaket oversendast til Olje- og energidepartementet (Miljøverndepartementet, 
2007, s. 248). Organ som kan gi motsegn etter desse reglane, kan dessutan gjera bruk av forvaltningsklage, jf. vassdragsreguleringslova $₫ 12$ andre ledd andre setning, energilova $\$ 2$-1 sjuande ledd fjerde setning og vassressurslova $\$ 24$ tredje ledd andre setning.

Kommunen set etter pbl. $₫ 12-1$ andre ledd krav om at det blir utarbeidd reguleringsplan, anten fordi lova krev det, eller fordi det fylgjer av arealdelen i kommuneplanen. Større byggje- og anleggstiltak krev i utgangspunktet reguleringsplan, jf. 12-1 tredje ledd. For konsesjonspliktige anlegg for produksjon av energi etter energilova, vassressurslova eller vassdragsreguleringslova, jf. også $\ 12-1$ tredje ledd, tredje setning er det unntak frå kravet om reguleringsplan.

Då plan- og bygningslova vart vedteken med desse særreglane for energiproduksjonsanlegg, var omsynet til arealplanlegginga meint ivareteken dels gjennom regional planlegging. Slik planlegging var sett på som viktig for å få til den mest eigna lokaliteten til anlegga. I førearbeida er det vist til at det er utarbeidd retningsliner for regional planlegging både for vindkraft og vasskraft (Miljøverndepartementet, 2007, s. 40-41). Førearbeida understrekar dessutan at sektorstyresmaktene må vektleggja eventuelle kommunale arealplanar eller reguleringsplanar i konsesjonsarbeidet (Miljøverndepartementet, 2007, s. 40-42). Som vi skal sjå nedanfor, kan det synast som denne føresetnaden om bruk av regional planlegging ikkje har blitt heilt som ein såg føre seg. Stortingsmeldinga for vindkraft gav ikkje bod om nokon ny giv for kommunen som arealforvaltar i område der det blir søkt om å etablera vindkraft. Ynske om sterkare involvering av kommunane var likevel uttrykt (Olje- og energidepartementet, 2019, s. 30), men framleis slik at ei sterk sektorstyring framleis var prioritert. Stortinget ville det likevel som nemnt annleis og bad regjeringa koma med eit framlegg om korleis ein kan ta handsaming av vindkraftverk inn igjen i plan- og bygningslova (Stortinget, 2020, Vedtak i korthet).

\section{Eit oppheva planverktøy: Samla plan for vassdrag}

Samla plan for vassdrag var i mange år eit sentralt forvaltningsverktøy for prioritering av vasskraftverk. Planarbeidet kom nok dels i gang som eit svar på dei mest konfliktfylte utbyggingssakene, slik som kraftutbygginga 
i Alta-vassdraget (Vinjar \& Rosvold, 2018). Målet med Samla plan var å få til ei samla, nasjonal forvaltning av vassdraga. I Samla plan var metoden at ein søkte å sortere vasskraftprosjekt ut frå konfliktgrad med ulike brukarinteresser halde saman med kraftverksøkonomi. Opplegget var at prosjekta med best økonomi, og med lågast konfliktgrad kunne konsesjonshandsamast. Dei meir konfliktfylte eller «kostbare» tiltaka kunne ikkje konsesjonshandsamast (NVE, 2020). Det var dessutan mogleg å søke om fritak frå Samla plan for prosjekt som ikkje var klarert. Både omplassering og fritak vart handsama av Miljødirektoratet i samråd med NVE.

Kroken på døra for Samla plan for vassdrag kom i 2015-16, med stortingsmeldinga Kraft til endring. Der vart det foreslått å avvikla heile Samla plan (Olje- og energidepartementet, 2015, s. 188-189). I stortingsmeldinga vart det sagt at Samla plan har vore eit nyttig verktøy for å redusera konfliktar i norsk vasskraftutbygging, og at planane har gitt ei god oversikt over ressursane. No meinte ein likevel at nytten var liten, og at planen ikkje var oppdatert på mange år. Kunnskap om miljøstatus i vassdraga som kom fram i arbeidet med "vannområdeplanar», sjå nedanfor, var trekt fram som eit argument for at behovet for Samla plan no var mindre. I stortingsmeldinga der avviklinga vart foreslått, vart det dessutan sagt at relevant kunnskap frå planarbeidet framleis kan nyttast.

Samtidig vart det fremja eit forslag om at det burde greiast ut om ein skulle ha eit lovgrunnlag for sokalla tidleg avslag på konsesjonssøknader (Olje- og energidepartementet, 2015, s. 189 og 195). Ideen var at prosjekt som ein såg kunne ha «vesentlige negative virkninger for miljø eller annen arealbruk eller har svak prosjektøkonomi», burde avvisast tidleg i prosessen. Tanken var at eit slikt opplegg med tidleg avslag fekk litt av den same funksjonen som Samla plan hadde hatt.

Etter forskrift om konsekvensutgreiingar $₫ 15$ fjerde ledd er det også vedteke ein heimel for å la vera å senda melding med forslag til utgreiingsprogram viss den vidare sakshandsaminga er stansa «i samsvar med reglene i loven» saka blir handsama etter. Så langt kan eg ikkje sjå at det i dei relevante sektorlovene finst heimlar for slik stans av sakshandsaminga tidleg i prosessen. Forslaget om å førebu ein lovheimel for tidleg avslag for vindkraftsaker er teke opp att av NVE i ein rapport frå januar 
2020, og er no fylgt opp i stortingsmelding (Bjerkestrand mfl., 2020; Oljeog energidepartementet, 2019, s. 32-33). Heimel for å stansa sakshandsaminga finst i konsekvensutgreiingsforskrifta $₫ 16$ tredje ledd. Ei slik avgjerd skal grunngivast, og er sjølvsagt alvorleg for søkar. I realiteten vil nok ei avveging og grunngiving etter denne regelen ikkje skilja seg så mykje frå eit endeleg avslag etter den aktuelle sektorlova. Ein ting er at «funksjonen» kan vera den same, mellom tidleg avslag og avslag på utbygging som fylgje av Samla plan. Oppfatningar og tillit til vedtaka kan likevel vera ulike. Samla plan var eit verktøy som låg der over tid, og som var relativt breitt forankra både lokalt og nasjonalt. Slik kunne verktøyet nettopp vera eigna til å gi legitimitet til avgjerder. Moglegheita for at det blir gitt eit slikt tidleg avslag hjå sektorstyresmakt, vil etter mi oppfatning vanskeleg kunna nå dette formålet.

\section{Regionale planar for vindkraft og småkraft}

I plan- og bygningslova kapittel 8 er det reglar for regionale planar. Fylkestinget vedtek som hovudregel dei regionale planane, jf. plan- og bygningslova $\$$ 8-2 og 8-4 første ledd jf. \$3-4. Regionale planar har, jf. pbl. $\$ 3$-4, til formål å stimulera til den «fysiske, miljømessige, helsemessige, økonomiske, sosiale og kulturelle utviklingen i en region». Både statlege organ og andre kommunar kan på nærare vilkår, jf. pbl. \$ 8-4, krevja at handsaminga av den regionale planen blir teken inn til departementet. Etter $\$ 8$-4 andre ledd har departementet kompetanse til å gjera dei endringane som «finnes påkrevd».

Regionale planar skal «legges til grunn» for både regional, statleg og kommunal planlegging, jf. $₫ 8$-2. Føresegna er meint å gi føringar for vidare planlegging (Miljøverndepartementet, 2007, s. 200). Ei utfordring er det likevel at det ikkje er heilt klart kva føringar omgrepet «legges til grunn» gir for skjønnet til forvaltninga. For vindkraftsaker og småkraftsaker spesielt har det i den seinare tid dessutan kome signal om at det skal leggjast vekt på fylkeskommunal planlegging i konsesjonsprosessar (Kommunal- og forvaltningskomiteen, 2018). Liknande signal kan lesast i den nye stortingsmeldinga om vindkraft på land. Samtidig kan det nok synast som moglegheita for å inkludera og adressera eit mangfald av interesser som ein regional plan gir, ikkje blir teken heilt 
på alvor. I alle høve blir det argumentert for at eit opplegg med «regionvis samlet behandling kan avlaste behovet for regionale planer». Korleis dette vil fungera, avheng av om ein i praksis lukkast med målet om å inkludera fylkeskommunen meir aktivt i sakshandsaminga av konkrete vindkraftsaker (Olje- og energidepartementet, 2019, s. 33). Med vedtaket om å finna ei løysing for igjen å handsama vindkraft etter plan- og bygningslova (Stortinget, 2020, Vedtak i korthet) kan også regionale planar bli viktigare for plan- og konsesjonsprosessane. Regionale planar kan, om dei fungerer etter intensjonen, spela ei rolle for å sikra klimaomsynet i avvegingane innanfor forvaltningsskjønnet til sektorstyresmaktene, og slike planar kan vera med å sikra balansen mellom bruk og vern på eit meir overordna nivå.

I 2007 vart regionale planar lansert som eit viktig verktøy for å koordinera ulike interesser og administrasjonsnivå både i småkraftsaker og i vindkraftsakene (Miljøverndepartementet, 2007, T-1458/2007). Som vi såg, var noko av forklaringa på at kommunen vart sett på «sidelinja» i vind- og vasskraftsaker, at omsynet til arealplanlegginga skulle ivaretakast gjennom regionale prioriteringar. For vindkraft har bruk av regionale planar for å styra utviklinga med omsyn til vindkraftutbygging vore ein klar intensjon frå lovgivar si side (Wiig mfl., 2019, s. 4). Likevel ser vi at berre seks av (den gong) nitten fylke utarbeidde slike planar (Wiig mfl., 2019, s. 5, 9). Ifylgje vindkraftmeldinga er det tale om sju planar (Olje- og energidepartementet, 2019, s. 33). Så langt eg er kjent med, vart regionale planar (fylkesdelplan) for småkraftverk utarbeidd i berre to fylke, og etter det eg forstår, har ikkje NVE ei full oversikt over kvar det vart utarbeidd slike planar. Dei regionale planane for vindkraft vart dessutan berre i varierande grad vektlagt i konsesjonsprosessen, og tilhøvet mellom regionale planar og konsesjonsprosessen synest uavklara (Wiig mfl., 2019, s. 5, 34).

Kommunen som talsmann for lokale omsyn har altså fått mindre å seia. Dette fråværet synest ikkje å vera erstatta av avvegingar av arealbruken på regionalt nivå. Dermed er både materielle avvegingar mellom klima- og miljøomsyn og prosessar der folkevalde på kommunalt eller regionalt nivå har det siste ordet svekte. I lys av dette er det særleg interessant at også NVE i den nemnde rapporten «Konsesjonsprosessen 
for vindkraft på land» tek til orde for at det bør vurderast korleis lokal og regional planlegging kan få ei meir sentral rolle i vindkraftsaker enn tidlegare. Forslaget er frå NVE si side særleg motivert av behovet for å sikra lokal forankring og auka tillit til konsesjonsprosessane (Bjerkestrand mfl., 2020, s. 18, 46). Det blir peika på at slike planar ikkje er ein føresetnad for konsesjonshandsaminga, ilag med at ein altså ser føre seg at konsesjonsstyresmaka si regionvise handsaming av sakene kan «avlaste behovet for regionale planer» (Olje- og energidepartementet, 2019, s. 33). Regionvis sakshandsaming med ei sterkare inkludering av fylkeskommunen kan altså vera aktuelt. Kjem slik sakshandsaming som erstatning for lokal og regional planlegging, vil framleis det demokratiske elementet $i$ at konsesjonsvedtaka blir vedtekne med grunnlag i lokale planar, mangla. Klimaomsynet kan bli vurdert også hjå sektorstyresmaktene med ei slik regionvis sakshandsaming. Avvegingar mellom klimaomsynet og andre omsyn på regionalt nivå vil slik eg ser det, framleis ha ei dårlegare forankring enn gjennom formell bruk av regionale planar. Avhengig av korleis pålegget frå Stortinget om igjen å inkludera vindkraft i plan- og bygningslova blir fylgt opp, kan det også sjå ut som desse breiare avvegingane no kan bli ivaretekne gjennom regional planlegging.

\section{Vassrammedirektivet implementert gjennom vassforskrifta}

Eg vil også heilt kort reisa spørsmål om korleis forvaltningssystemet i vassforskrifta kan påverka kva vekt klimaomsynet kan få i saker som gjeld konsesjonar til nye vasskraftverk (Vassforskrifta, 2006). Vassforskrifta implementerer vassrammedirektivet i norsk rett (EU, direktiv 2000/60/EF). Eg peikar her berre på nokre utgangspunkt for vurderinga.

Verkemiddelet for å nå miljømåla etter vassforskrifta er vassområdeplanar med tilhøyrande tiltaksprogram. Alle nye tiltak i vassdrag som kan medføra at miljømåla i $\$ \$ 4-7$ i forskrifta ikkje blir nådd, eller at miljøtilstanden blir dårlegare («tilstanden forringes»), må vurderast etter vilkåra i vassforskrifta $₫ 12$. EU-domstolen har lagt til grunn at både plikta til å hindra at miljøtilstanden blir dårlegare, og plikta til å betre miljøtilstanden er rettsleg bindande (EU-domstolen, C-461/13, Weser og Havs och vattenmyndigheten, 2016). 
Årsaka til at miljømåla ikkje blir nådd, eller at tilstanden blir «forringa» etter $\$ 12$ første ledd bokstav a, må anten skuldast nye endringar i dei fysiske eigenskapane til ein overflatevassførekomst eller endra nivå i ein grunnvassførekomst. Etablering av vasskraftverk med oppdemming, magasin, demningar, uttak av vatn og deponering av massar er døme på tiltak som kan falla inn under $\$ 12$ første ledd bokstav a (Klima- og miljøverndepartementet, 2015, S. 5).

Alternativt må årsaka etter $₫ 12$ første ledd bokstav b vera ny berekraftig aktivitet som medfører «forringelse» i miljøtilstanden i vassførekomsten. EU-domstolen har avklara at ein vassførekomst er utsett for forringing om eit av kvalitetselementa i vedlegg $\mathrm{V}$ til direktivet fell eit nivå, sjølv om ikkje denne endringa fører til at heile overflatevassområdet rykker ned ein tilstandsklasse (EU-domstolen, C-461/13, Weser avsnitt 70 og Platjouw, 2021, s, 57). Tiltak som kan føra til ein dårlegare miljøtilstand enn «god», kan ikkje tillatast etter dette alternativet, jf. forskrifta $\$ 12$ første ledd bokstav b og direktivet artikkel $4 \mathrm{nr} .7$ andre strekpunkt.

I vassforskrifta $₫ 12$ andre ledd bokstavane a til c er det tre kumulative vilkår som i tillegg må vera oppfylt for å gi løyve til tiltak som altså kan føra til «forringelse», eller at miljømåla ikkje blir nådd, jf. $\$ 12$ første ledd. Terskelen for å få konsesjon både i vassressurslova $\$ 25$ og vassdragsreguleringslova $₫ 5$ er interesseavvegingar som opnar for konsesjon om fordelane ved tiltaket er større enn ulempene. At det er større fordelar enn ulemper ved tiltaket, vil ikkje nødvendigvis vera nok for å tilfredsstilla standarden i vassforskrifta $\$ 12$ andre ledd bokstav b. I for eksempel konsesjonsheimelen i vassressurslova $\$ 25$ er det eit vidare spekter av interesser som er relevante i interesseavveginga. Etter vassforskrifta $\ 12$ andre ledd bokstav a skal i tillegg alle praktiske tiltak for å unngå ei negativ utvikling i vassførekomsten settast i verk, og etter bokstav c skal ein vurdera om det er slik at målet med tiltaket på grunn av tekniske hinder eller uforholdsmessig store kostnader ikkje «med rimelighet» kan nåast med middel som er vesentleg betre for miljøet.

Det interessante spørsmålet i denne samanhengen er om klimaomsynet kan koma inn og telja som ein del av samfunnsnytten med tiltaket i vurderinga av om vilkåra for unntak frå forbodet mot forringing er oppfylt, jf. vassforskrifta $₫ 12$ andre ledd bokstav b. Og ja, dette vart 
gjort i saka Schwarze Sulm (EU-domstolen, Østerrike mot kommisjonen, C-346/14). Kommisjonen meinte at Austerrike hadde gitt løyve til eit vasskraftverk som ville medføra ei forringing av tilstanden i overflatevatnet i elva Schwarze Sulm frå «høj» til «god». Noko som ville vera forbode etter direktivet. Vidare at vilkåra for unntaka frå forbodet ikkje var oppfylt i artikkel 4, stk. 7, sml. vassforskrifta $\$ 12$ andre ledd. I vurderinga la EU-domstolen vekt på klimaomsynet mellom anna under tilvising til energipolitikken i EU, og det vart vist til at slike etableringar var viktige for å sikra måloppnåing etter Kyoto-protokollen. Ei viktig presisering $i$ den same saka er at det ikkje er nok å seia at vasskraftverk generelt er å rekna som ein berekraftig aktivitet. Vekting av klimaomsynet som del av samfunnsnytten blir neppe mindre viktig med det ansvaret som ligg på alle land gjennom Parisavtalen og ny politikkutforming innanfor EU, som i European Green Deal (EU-kommisjonen, 2019).

Det siste vilkåret er altså at formålet med dei nye inngrepa eller aktivitetane på grunn av manglande tekniske hinder («gjennomførbarhet») eller uforholdsmessig store kostnader, ikkje med «rimelighet kan oppnås med andre midler som miljømessig er vesentlig bedre». Vilkåret kan tilsynelatande krevja meir utførlege, eller dokumenterte, vurderingar av om alternative plasseringar osv. kan gi mindre negative miljøverknader enn det som i dag går uttrykkeleg fram av konsesjonslovene. Heller ikkje vassforskrifta er altså utforma slik at ho er til hinder for å realisera ein meir klimavenleg energipolitikk. Regelverket strammar likevel først og fremst inn vernet om miljøverdiane i vassdraga.

\section{Eit forsøk på overordna planlegging: Nasjonal ramme for vindkraft}

I mars 2019 la Norges vassdrags- og energidirektorat (NVE) på oppdrag frå OED fram ei nasjonal ramme for vindkraft på land. Bakgrunnen var mellom anna eit ynske om meir føreseieleg og effektiv konsesjonshandsaming i framtida (Olje- og energidepartementet, 2015, s. 193). Forslaget inneheldt eit oppdatert kunnskapsgrunnlag for landbasert vindkraft, og det vart lagt fram kart med forslag til dei mest eigna områda for lokalisering av vindkraft. Det viste seg å vera store forskjellar mellom område utpeikt som eigna for vindkraft i Nasjonal ramme og dei områda 
som var planlagt for vindkraft i dei regionale planane (Wiig mfl., 2019, s. 38). Nasjonal ramme for vindkraft framheva at konsesjonshandsaminga av einskildsaker ikkje skulle bli mindre viktig. Det vart også trekt fram at innanfor einskildområde som var peika ut som eigna, kunne det gjerne vera område som var mindre eigna. Samtidig vart det uttala at konsesjonssøknader utanfor dei utpeika områda ikkje ville få same prioritet. Vi ser altså ein viss likskap mellom dette arbeidet og den no oppheva Samla plan for vassdrag. Sjølv om prioritetssystemet ikkje var like formalisert som i Samla plan, såg altså ramma ut til å ha eit potensial til å gjera prosessar for plassering av nye vindkraftanlegg meir føreseielege. I oktober 2019 vart det klart at regjeringa ville trekkja heile ramma. Eit mål med ramma var at det skulle vera eit konfliktdempande verktøy. Etter over 5000 høyringsinnspel, der dei fleste var kritiske, fann ein at dette målet slett ikkje vart nådd. I staden leia dei mange høyringsinnspela mellom anna til at arbeidet med betring av konsesjonsreglane vart sett i verk (Bjerkestrand mfl., 2020). Ifylgje vindkraftmeldinga skal kunnskapsgrunnlaget frå nasjonal ramme vidareutviklast, og det blir viktig $\mathrm{i}$ konsesjonshandsaminga av nye søknader (Olje- og energidepartementet, 2019, s. 32).

\section{Oppsummerande refleksjonar så langt}

Konsesjonshandsaminga av både vasskraft og vindkraft har lenge langt på veg vore fråkopla plan- og bygningslova. Ei klar og godt synleg forankring for å ivareta klimaomsynet er dermed svekt. Vi har tidlegare hatt eit overordna planverktøy for store kraftutbyggingar. Gjennom ei klar prioritering av kva kraftverk som kunne konsesjonssøkast, fremja planverktøyet ei føreseieleg sakshandsaming. Nasjonal ramme for vindkraftverk er no lagt bort etter massiv motstand. Ramma hadde etter mi vurdering eit potensial tilå bli eit verktøy som gjennom prioriteringar både la til rette for ein klimavenleg energipolitikk og gjorde lokaliseringa og sakshandsaminga i desse sakene meir føreseielege for ulike interessentar - ikkje minst for dei mangearta brukar- og miljøinteressene i utmarka. Kanskje kan ein likevel oppnå litt av den same effekten gjennom bruk av den kunnskapen som er samla inn (Bjerkestrand mfl., 2020, s. 68; Olje- og energidepartementet, 2019, s. 32). Eit spørsmål for framtida blir no korleis, 
og om den innsamla kunnskapen også kan takast i bruk av lokale og regionale planstyresmakter.

\section{Kva vekt og relevans har så klimaomsynet etter dei tre sektorlovene?}

Spørsmålet i kapittelet her er kva plass klimaomsynet har i konsesjonsregelverket for vass- og vindkraft. Eit startpunkt i drøftinga av kva plass ulike miljøomsyn har i rettsbruken, er integrasjonsprinsippet (Backer, 2012, s. 66). Prinsippet går ut på at miljøomsyn er eit rettsleg relevant omsyn innanfor alle ulike sektorar (Backer, 2012B, s. 42, 46; Bugge, 2019, s. 154). Læra har, noko forenkla uttrykt, vore at kor strengt dette kravet er, fylgjer av korleis miljøomsynet er handsama i den konkrete lovgivinga (Bugge, 2019, s. 155). Ei viktig kjelde for å leggja vekt på miljøomsyn i dag er Grl $\$ 112$ (Backer, 2012, s. 66). Integrasjonsprinsippet er forstått slik at uansett formålsparagraf, og føresegner som direkte gjeld spørsmålet, så må ei lov som regulerer verksemd som kan ha negative miljøverknader, lesast slik at forvaltninga ikkje berre har høve til, men også plikt til å greia ut miljøverknader og leggja vekt på desse i avgjerda (Bugge, 2019, s. 155). I klimadommen stadfestar Høgsterett både at Grl $\$ 112$ har relevans i lovtolkinga, og er eit tvunge omsyn ved utøvinga av skjønnet i forvaltningsavgjerder (Høgsterett, 2020, avsnitt 145). Spørsmålet er korleis denne forståinga av at miljøomsyna alltid er relevante og må takast omsyn til, påverkar vekta av klimaomsynet innanfor avvegingane (forvaltningsskjønnet) i sektorlovene vi tek føre oss. Mitt inntrykk er at så langt har merksemda om verknaden av integrasjonsprinsippet gjerne vore retta mot dei lokale miljøulempene av eit tiltak. Backer syner rett nok også til klimakonvensjonen, og peikar på denne som eit relevant argument ut frå det folkerettslege presumsjonsprinsippet, og at bruken av omgrepet i Rio-erklæringa kan trekkja i same retning (Backer, 2012B, s. 46).

Rekkevidda av integrasjonsprinsippet er likevel uklar. Framover bør det drøftast meir utførleg $k v a$ miljøomsyn som kan fremjast eller handterast i forvaltninga i tråd med dette integrasjonsprinsippet, og ikkje minst korleis motstridande miljøinteresser kan handterast. Tilnærminga til 
prinsippet med eit innhald som at «summen av de enkelte avgjørelser blir mer miljøgunstige enn de ellers ville ha vært», og miljøomsyn derfor nesten utan unntak får vega tyngst (Backer, 2012B, s. 50), kan i dag bli problematisk om ein ikkje er medviten klimaomsynet. Ei hovudutfordring for styresmaktene er jo nettopp korleis klimaomsyn skal vegast mot andre miljøomsyn. Også andre slag miljøomsyn kan i einskildsaker stå mot kvarandre. Dessutan kan brukarinteresser som ikkje fell inn under ei meir snever forståing av omgrepet miljøinteresser, også fremja bruk som gagnar miljøet. Grl $\$ 112$ er i alle høve etter klimadommen ei klar forankring for at klimaomsynet må handterast på same måte som andre miljøomsyn.

Kva seier så formålet med lovene om klimaonsynet? I vassressurslova, som heimlar konsesjon til dei mindre kraftverka, finn ein i $\$ 1$ at lova har til formål «å sikre en samfunnsmessig forsvarlig bruk og forvaltning av vassdrag og grunnvann». Verken miljø eller klima er omgrep som er nytta, sjølv om lova er av relativt ny dato. I staden finn vi omgrepet «samfunnsmessig forsvarlig bruk og utnytting». Det er likevel klart at det å sikre miljøet, ikkje berre er innanfor det som er rekna som «samfunnsmessig forsvarlig», men også er eit sentralt formål. Fleirtalet i NOU-utvalet sa: «Begrepet 'samfunnsmessig forsvarlig' omfatter både miljøhensyn, medregnet hensynet til å sikre biologisk mangfold, og hensynet til aktuelle bruksformål og økonomi» (NOU 1994: 12, s. 402). Lovmotiva understrekar at måla lova skal ivareta, også må sikrast på lang sikt. Legg vi utvalsfleirtalet si forståing til grunn, kan klimaomsynet forankrast både som eit omsyn som er direkte relevant etter ordlyden «samfunnsmessig forsvarlig bruk», og med tilvising til miljøomsyn generelt, og aktuelle bruksformål. I dag vil nok også økonomiomsynet vera ei relevant forankring for klimaomsynet. Klimapolitiske dokument kan visa oss at det samfunnsøkonomisk er meir lønsamt å gjera noko med klimaproblemet i dag enn å ta alle kostnadene med klimaendringane i framtida. I ei konkret avveging med omsyn til å tillata eit lite kraftverk kan eit slikt omsyn likevel få lita vekt i møte med lokale miljøskadar og negative verknader for ålmenta.

Vassdragsreguleringslova er kompetansegrunnlag for å gi løyve til alle kraftverk med regulering eller overføring over ein viss storleik, og i 
tillegg dei største elvekraftverka jf. $\$ 3$. Vassdragsreguleringslova frå 1917 har ikkje ei tilsvarande føresegn om formålet i lova som gir rettleiing om kva slags omsyn som er relevante (Vassdragsreguleringslova, 1917). Dette til trass for ein ganske nyleg språkleg revisjon av lova. Integrasjonsprinsippet, og ikkje minst Grl $\$ 112$, fortel oss som vist at miljøomsyn likevel er relevante.

Energilova $\$$ 1-2 framhevar at produksjon av energi skal skje på ein samfunnsmessig rasjonell måte, ein skal ta omsyn til allmenne og private interesser, og med det miljøet (Energilova, 1990, \$ 2-1). Førearbeida til energilova tek, så langt eg kan sjå, ikkje føre seg klimaomsynet som ein særleg motivasjon for lova, eller for det å gi konsesjon til vindkraftverk spesielt. Men med den vide formuleringa av formålet er det i dag vanskeleg, også utan ei tilvising til Grl $₫ 112$, å avvisa at klimaomsyn er eit relevant omsyn i bruk av dei ulike reglane i lova (Backer, 2012B, s. 44).

Både formålsføresegna i vassressurslova og energilova gjer bruk av typiske dynamiske uttrykk som er kjenneteikna av at innhaldet må «hentast utanfrå». For å bruka orda til Nils Nygaard: «Tankegangen er at lovteksten på ein måte er eit 'hylster', som må fyllast med eit stoff som lova sjølv ikkje har» (Nygaard, 2004, s. 190-191). Her må det presiserast at vi er på området for forvaltningsretten, og dermed på området for legalitetsprinsippet, og vi må forventa ein viss lojalitet til lovgivar. Samstundes er det tale om å gi løyve til verksemd som ikkje nokon har krav på. Det interessante i denne samanhengen er jo at det å fremja klimaomsynet neppe vil gå utover den som søker om løyve til høvesvis vind- eller vasskraftverk, men andre miljøomsyn og andre lokale brukarinteresser. Denne dimensjonen i avvegingane kjem også tydeleg til uttrykk i den massive motstanden ein kan registrera mot aktuelle vindkraftprosjekt. Verken det at klimaomsynet kan vera ein del av avvegingane til styresmaktene i desse sakene, eller at vindkraftverka kan vera ein del av ei klimaløysing, ser altså ut til å verka som ein slags dempar for denne motstanden. Skulle det vera tolkingstvil, må vi på dette punktet også kunna visa til Grl $\$ 112$ og forståinga som vart lagt til grunn i Høgsterett (Høgsterett, 2020, avsnitt 147). Så langt kan vi altså slå fast at klima er eit relevant omsyn i bruken av desse lovene i dag. 
Kva vekt har så klimaomsynet ved tildeling av løyve til produksjon av fornybar energi etter sektorlovene? Felles for dei to lovene som heimlar konsesjon til vasskraftanlegg, er at dei gir uttrykk for at konsesjon berre kan givast viss fordelane ved tiltaket overstig skadar og ulemper for allmenne og private interesser. Vi kan altså konstatera at det er tale om kan-reglar.

Identifiserer vi klimaomsynet med utbyggjarsida, er det altså eit klart utgangspunkt at andre omsyn ikkje må vika for klimaomsynet. Korleis den nærare avveginga skal skje, er eit meir ope spørsmål. Heller ikkje her finn vi noko i lovteksten om kva rolle den fornybare energien har i overgangen til eit lågutsleppssamfunn eller andre liknande formuleringar som vi hugsar frå dei politiske dokumenta. Vassdragslova frå 1917, som altså heimlar konsesjon til dei store regulerbare kraftverka, er i utgangspunktet frå ei tid som gjer at ein ikkje kan venta slike spor. Dei rettslege rammene er vide, og det blir fort eit politisk spørsmål om vi skal gi konsesjon. For at konsesjon skal bli gitt, må altså fordelane vera større enn ulempene for allmenne eller private interesser jf. vassdragsreguleringslova $\$$ 5. Ei retningsline for skjønnet er dessutan at ein skal ta omsyn til «andre skade- og nyttevirkninger av samfunnsmessig betydning». Dermed kan ein trekkje inn både direkte og indirekte fordelar (Bugge, 2019, s. 349).

Med kunnskap om klimavanskane, og den viktige rolla til vasskrafta, er det ikkje tvilsamt å leggja klimaomsyn i vektskåla for fordelar med tiltaket. Uansett kan ein her visa til Grl $\$ 112$ som tolkingsmoment, og som uttrykk for omsyn som skal vera med i vurderinga, sjå avsnittet over om Grl $\$ 112$. Naturinngrepa som tiltaket fører med seg, er naturleg argument mot ei slik utbygging, og Grl $₫ 112$ kan også takast til inntekt for vekta av desse interessene. Naturverdiar er dessutan, som vi såg, ivaretekne gjennom vassforskrifta. For etablering eller utvidingar av vasskraftverk kan framleis eit mangfald av negative verknader for landskap, biologi, friluftsliv osv. melde seg, sjølv om ein blir flinkare til å gjera slike utbyggingar på ein miljøskånsam måte.

Vassressurslova er konsesjonslova for dei mindre kraftverka, sml. vassdragsreguleringslova $₫ 3$. Den sentrale rolle vasskrafta har hatt i 
samfunnsbygginga i Noreg, er drøfta i førearbeida (NOU 1994: 12, kapittel 21). I drøftinga av berekraft-omgrepet kan ein lesa: «Vannressursene er i seg selv fornybare i utgangspunktet, men deler av det økologiske system langs og i vassdragene må betraktes som en ikke-fornybar kapital» (NOU 1994: 12, s. 117). Der går det også fram at ein ser at vasskrafta kan vera eit alternativ til meir «miljøbelastende energiproduksjon». Utsegna kan takast til inntekt for at klimaomsynet er eit moment som bør ha ei viss vekt også direkte etter vassressurslova. Ordet «fordeler» kan som nemnt uansett ikkje vera bunde til dei faktiske tilhøva lovgivar såg føre seg då lova vart vedteken. Klimaomsyn i nærmiljøet i form av t.d. flaumdempande effektar eller klimaomsynet i stort kan altså vera relevante omsyn. Eit spørsmål er likevel om samanhengen mellom klimafordelen og tiltaket kan bli så vag eller liten at den ikkje lenger kan reknast som ein reell og relevant fordel, eventuelt slik at den berre får lita eller vekt i den endelege avveginga.

Verken eit lite småkraftverk på Vestlandet eller eit vindkraftverk i Trøndelag løyser klimakrisa, eller? Bugge omtalar «The tyranny of small decisions» (Bugge, 2019, s. 70 flg.). Kvar for seg er inga lita forureining så skadeleg. Til saman kan likevel dei mange små avgjerdene føra oss over i eit alvorleg miljøproblem. I omstillinga til ein mindre klimaskadeleg energibruk melder det same problemet seg. Aleine vil ikkje eit småkraftverk redda klimaet, men vi må ha mange små vedtak i retning av å produsera fornybar energi om vi skal realisere ein meir klimavenleg energipolitikk. Eksempelet illustrerer utfordringa klimaproblemet gir både for forvaltning og lovgivar. Den vanlege «resipient-tenkinga» $\mathrm{i}$ miljøforvaltningsretten, eller for så vidt alminnelege krav til årsakssamanheng mellom tiltak og verknad, kan gi lite rettleiing i spørsmål som vedkjem klimaspørsmålet i einskildsaker.

Energilova er altså heimelslova for å gi konsesjon til den for tida så «omsuste» vindkrafta på land. Etter energilovforskrifta $\$$ 3-1 andre ledd må ikkje vindkraftanlegg på land med installert effekt i anlegget på mindre enn $1 \mathrm{MW}$ ha konsesjon. Har tiltaket fleire enn fem vindturbinar, skal likevel anlegget konsesjonssøkast. Desse minste tiltaka blir altså handsama etter plan- og bygningslova. Når søknad om konsesjon blir sendt inn, skal konsekvensutgreiinga fylgja søknaden, jf. energilova $₫$ 2-1 
andre ledd (Fauchald, 2018, s. 8). Konsesjonsregelen i $\$$ 3-1 er ein interessant konstruksjon med eit reint kan-skjønn til forvaltninga, utan å knyte andre vilkår eller retningsliner til vurderinga (For meir sjå Winge, 2013, kapittel 4.) Formålsparagrafen i energilova viser altså særleg til det «samfunnsmessig rasjonelle», noko som har gjort at dei samfunnsøkonomiske vurderingane er sentrale i konsesjonsvurderinga etter energilova. Som for dei andre konsesjonslovene er klimaomsynet eit relevant omsyn også etter energilova. Vekta av omsynet vil likevel også her sjølvsagt variere frå sak til sak. Den rettslege utviklinga elles kan dessutan påverka kva gjennomslagskraft klimaomsynet vil få overfor andre miljø- og brukarinteresser. For det første må ein kunna leggja til grunn at måloppnåing etter klimalova, jf. Grl $\$ 112$, kan gi auka vekt til klimaomsynet i einskildsaker. Det same kan fylgja av det vedtekne samarbeidet om felles måloppnåing med EU.

\section{Naturmangfaldlova og klimaomsynet}

For alle styresmakter som tek avgjerder som kan påverka naturmangfaldet, gjeld naturmangfaldlova. Grunnleggjande miljørettslege forvaltningsprinsipp skal vurderast i alle vedtak. Vurderingane skal dessutan gå fram av vedtaka, jf. naturmangfaldlova $\$ 7$. Det gjeld altså eit eksplisitt krav om grunngiving i tillegg til den alminnelege plikta i forvaltningslova $\$ 2$. Både formålet i naturmangfaldlova og bruken av lova elles må vi sjå i samanheng med Grl $\$ 112$. Etter førearbeida skal lova med støtte av det som var Grl $\$ 110$ b då lova vart vedteken, verka inn på både tolking og skjønnsutøving etter andre lover (Backer, 2010, s. 44).

Etter $\$ 1$ i lova er «[l] ovens formål [...] at naturen med dens biologiske mangfold og økologiske prosesser tas vare på ved bærekraftig bruk og vern, også slik at den gir grunnlag for menneskenes virksomhet, kultur, helse og trivsel, nå og i fremtiden, også som grunnlag for samisk kultur».

Kva slags miljøforvaltningsprinsipp er det så energistyresmaktene skal leggja til grunn i utøvinga av offentleg myndigheit? Er dette miljøomsyn som åleine femner om «det klassiske naturvernet» - altså dei lokale miljøverdiane? 
Eg tek her føre meg tre av forvaltningsprinsippa i lova. Kunnskapsprinsippet i $₫ 8$ set krav om at offentlege vedtak som gjeld naturmangfaldet, helst skal treffast på vitskapleg grunnlag. Føresegna supplerer det grunnleggjande prinsippet i forvaltningslova $₫ 17 \mathrm{om}$ at saka skal vera så godt opplyst som mogleg. Kva krav ein set til kunnskapsgrunnlaget, skal stå i eit rimeleg forhold til karakteren på saka og risiko for skade på naturmangfaldet (Miljøverndepartementet, 2008, s. 380). Kunnskapsgrunnlaget for eit vedtak om eit mikrokraftverk vil til dømes vera eit anna enn for ei større kraftutbygging (Miljøverndepartementet, 2008, s. 380). I juridisk teori er standpunktet at brot på retningslina i $\$ 8$, lettare enn brot på alminnelege forvaltningsrettslege reglar, kan føra til at eit vedtak er ugyldig (Backer, 2010, s. 96). Eit spørsmål er om $\$ 8$ bør supplerast med eit tilsvarande eksplisitt krav til kunnskap om eventuelle gunstige eller ugunstige effektar for klimaet av eit forvaltningsvedtak. Eit eige spørsmål er om ikkje ei slik forståing også er i betre samsvar med både det materielle og prosessuelle innhaldet i Grl \$112. Eit argument mot eit slikt allmennkrav på lovsnivå er sjølvsagt at det vil vera ressurskrevjande å handheva. På den andre sida vil kanskje eit slikt krav vera eigna til å synleggjera kva miljø- og klimaverknader som gjerne uansett skal utgreiast både på plan- og tiltaksnivå. (Sjå prosjektdirektivet art. 5 jf. vedlegg IV og plandirektivet art. 5 jf. vedlegg I. Sjå også Fauchald og Schütz, 2020.)

Føre-var-prinsippet er heimla i $\$$ 9. Prinsippet rettar seg mot korleis ein skal handtere $t v i l$ om konsekvensar for miljøet. Etter $\$ 9$ første punktum skal ein om vedtak må treffast utan tilstrekkeleg kunnskap om verknadene for naturmiljøet, søke å unngå mogleg «vesentlig skade på naturmangfoldet». Andre punktum regulerer situasjonar der det er risiko for «alvorleg eller irreversibel skade på naturmangfoldet». I desse sakene skal ikkje mangel på kunnskap nyttast som grunngivnad for å utsetta eller unnlata å treffa forvaltningstiltak. Sidan prinsippet er ei retningsline, og skal leggjast til grunn av sektorstyresmaktene i det konkrete vedtaket, er det usikkert kva innverknad prinsippet vil få i utbyggingssaker som dei vi har føre oss. I denne samanhengen er det særleg interessant om innhaldet i prinsippet blir påverka av kva type vedtak det er tale om. Kva seier naturmangfaldlova $₫ 9$ om handteringa av usikre miljøverknader ved etablering av tiltak som er rekna som gunstige for klimaet? Fell det til 
dømes innanfor skjønnet til forvaltninga å tola større uvisse for det lokale miljøet dersom klimagevinsten frå tiltaket synest særleg stor?

I $\$ 10$ finn vi prinsippet om økosystemtilnærming og samla belastning. Tanken er at eigenskapane ved eit økosystem og naturverdiane det representerer, skal vera utgangspunkt og ramme når planar og einskildtiltak som kan påverka eit økosystem, skal vurderast og avgjerast. Økosystem må ideelt sett handterast som ein heilskap, og alle vedtak som gjeld økosystemet, bør sjåast samla. I praksis er dette ei vanskeleg oppgåve, og har vore rekna som ei utfordring både rettsleg og administrativt. Truleg er det ei utvikling både i forsking og forvaltning som gjer slike økosystemvurderingar meir handterlege (Hagen mfl., 2019). Som vi såg, har ein nettopp for vassdragsforvaltninga også teke eit steg i retning av å få til ei økosystembasert forvaltning. I rapporten frå NVE til OED om endringar i konsesjonssystemet er dessutan eit av forslaga å leggja opp til handsaming av konsesjonssøknader region- eller områdevis. Både å auka lokal og regional forankring, og det å kunna sjå fleire tiltak i samanheng er nemnt som formål (Bjerkestrand mfl., 2020, s. 29; Olje- og energidepartementet, 2019, s. 33).

Kan så klimaomsynet koma inn i vurderinga av kva som skal tolast $\mathrm{i}$ eitt gitt område samla sett? Økosystemet i eitt område kan vera påverka av alt frå vegar, hyttebygging til industri - og så er spørsmålet om det skal tolast eit nytt energiproduksjonsanlegg. Backer peikar på at ei avveging best kan skje i ein generell strategi eller forvaltningsplan (Backer, 2010, s. 104). Kanskje kan slike verktøy også gjera at ein i tide seier nei til andre inngrep for å kunna prioritera for eksempel meir klimavenleg energiproduksjonen. Forslaget om områdevis sakshandsaming i rapporten frå NVE, som no også er fylgt opp i stortingsmeldinga, kan vi sjå som eit steg i ei slik retning (Olje- og energidepartementet, 2019, s. 29). For skadelidande brukar- eller miljøinteresser kan det vera ei mager trøyst at tiltaket er aldri så klimagunstig. Går ein for langt i vektleggja dei klimagunstige sidene til eit tiltak i sakshandsaminga, kan ein dessutan koma i fare for å vatna ut heile tanken om ei økosystemtilnærming. Dessutan kan også klimaendringar gjerne gjera naturmiljøet meir sårbart, slik at vurderingar av kva inngrep som kan tolast i eitt område må skje i lys av slik kunnskap. 
Forvaltningsprinsippa i naturmangfaldlova er sentrale for å sikra at viktige miljøverdiar blir tekne omsyn til i sakshandsaminga. Kravet til grunngiving er viktig for å sikra truverd og tillit til at forvaltninga av desse verdiane skjer i samsvar med lova. Mangelen på slike vurderingar er noko som kan prøvast for domstolane, og eventuelt vurderast som sakshandsamingsfeil etter forvaltningslova $₫ 41$. Prinsippet i nml. $\$ 10$ om økosystemtilnærming understrekar at det å treffa gode vedtak av omsyn til det samla ressursgrunnlaget i desse sakene er vanskeleg utan overordna styring. Eit spørsmål er som nemnt om klimaomsynet burde ivaretakast og synleggjerast på tilsvarande måte som dei ulike prinsippa i naturmangfaldlova. Ei slik lovendring vil sikra demokratisk legitimitet til ein viktig del av integrasjonsprinsippet i tida som kjem. Som vist i avsnittet over om Grl \$ 112 har Høgsterett peika på at Grl 112 - som også femner om klimaet - er eit tvunge omsyn i alle forvaltningsavgjerder. Spørsmålet handlar altså meir om synleggjering, enn å lage naudsynt heimelsgrunnlag.

\section{Ulike rammevilkår for verdiflyt frå vindkraft og vasskraft}

Rammevilkåra for verdiflyt frå vindkrafta og vasskrafta er ulike. I lang tid har vi hatt stabile ordningar som har sikra kommunar og fylke inntekter frå vasskraftverksemd utover ordinære skatteinntekter. Sentrale ordningar er konsesjonskraft og konsesjonsavgifta (Vassdragsreguleringslova, 1917, $\$ \$ 22$ og 14). Etter gamalt var konsesjonskrafta ei ordning for å sikra at distrikta der utbygginga fann stad, fekk tilgang på rimeleg kraft. Konsesjonsavgifta skulle på den andre sida vera kompensasjon for skader og ulemper som ikkje vart erstatta på anna vis, og avgifta skulle gi lokalmiljøet del i verdiskapinga som fann stad med utbygginga. I vassdragsreguleringslova $\$ 17$ er det dessutan reglar som gir heimel for at den som får konsesjon, set av pengar i fond som tilgodeser lokale formål. I tillegg kjem særlege reglar for vasskrafta om grunnrenteskatt og naturressursskatt (NOU 2019: 16, s. 148-149). For den som ferdast i utmarka, vil det altså vera mogleg å sjå ein samanheng mellom naturinngrepa, kraftproduksjonen og den økonomiske stoda lokalt. For vindkraft har ein 
til no ikkje vedteke slike særlege ordningar. Kommunane har høve til å krevja eigedomsskatt for vindkraftverka. Heller ikkje i den nye stortingsmeldinga om vindkraft på land vart det lagt fram konkrete endringar på dette punktet. Det er likevel uttala at regjeringa grundig vil vurdera fordelar og ulemper med lokal kompensasjon og koma attende til Stortinget med spørsmålet (Olje- og energidepartementet, 2019, s. 75-77). Nyleg vart dessutan ei ordning med ei moderat produksjonsavgift til kommunane sendt på høyring (Skatteetaten, 2021). Er dette starten på ein slags renessanse for den «energirettferda» lovskrivarane såg ut til å ha med seg i arbeidet då konsesjonsregelverket for vassdragsreguleringane vart utvikla? (Om energirettferd, sjå Jenkins mfl., 2016. s. 174 flg.; Salter mfl., 2018.) Framleis kan det nok vera så som så med incentiva for kommunar og fylke til å vera positive til utbygging av vindkraftverka. Skilnadene mellom det vi på overordna nivå kan omtala som verdiflyten frå vasskraft og vindkraft, bør vi nok heller ikkje oversjå i diskusjonar om kva tillit innbyggjarane har til konsesjonsreglane (NVE, 2020 s. 70). Så lenge skilnadene mellom tiltak som på mange måtar kan samanliknast, er så store i dette spørsmålet, kan det nok også vera vanskeleg å skilja mellom motstand mot vindkraftverk som kjem av engasjement og uro for naturinngrepet tiltaket medfører, og motstand som først og fremst spring ut av at ein meiner at vindkraftverket legg igjen for lite verdiar lokalt.

\section{Konklusjonar og refleksjonar om regelverket i lys av legitimitetsmarkørane}

Vi har no fått eit lite overblikk over rettsreglane som kan opna for etablering av tiltak for produksjon av fornybar energi i norsk utmark. Avstanden mellom bruken av fjellet, lukta av myr og mose, den opne utsikta og alt dette regelverket kan synast uendeleg lang. Er denne avstanden for stor, og kjensla er at regelverket ikkje seier noko om dei viktige spørsmåla for utmarka vår, ja, så kan det seia noko om legitimiteten til reglane. Omsynet til politiske målsetjingar om klimavenleg energiproduksjon gjer at forvaltning og aktørar kan få auka interesse for nyetableringar. Samtidig er vern om naturgrunnlaget, og andre brukarinteresser i utmarka, viktigare enn nokon gong. Målet med denne heilt overordna 
gjennomgangen har vore å reisa spørsmål ved om reguleringsteknikken sikrar tilstrekkeleg legitimitet kring avvegingane av dei grunnleggjande klima- og miljøomsyna som står på spel.

Poenget med ein føreseieleg rettssituasjon er at det skal vera mogleg å innretta seg (Mæhle \& Aarli, 2018, s. 105). I utmarka skulle det bety at det både for beiteinteresser, friluftsinteresser, miljøinteresser, utbyggingsinteresser og kommunar til ei viss grad er mogleg å føresjå den rettslege situasjonen som fylgjer av ei utbyggingssak. Konsesjonsreglar kjenneteikna av opne interesseavvegingar er utfordrande med omsyn til å skapa ein føreseieleg rettssituasjon. Aleine ut frå korleis rettsreglane er oppbygde, og særleg i kombinasjon med den nemnde særreguleringa i høve plan- og bygningslova, må altså interesser som desse sakene vedkjem, akseptere meir rettsuvisse enn der forvaltninga har mindre rom for vurderingar. Slike variasjonar mellom ulike rettsfelt er velkjent (Mæhle \& Aarli, 2018, s. 106). Gode reglar som sikrar føreseielege prosessar, kan bøta på rettsuvissa som fylgjer av uvisse kring utfallet av desse sakene. At det ikkje er same grunnen til å vera tilbakehalden med prøvinga av sakshandsaminga som den materielle vurderinga, og at denne må bli meir inngåande dess større konsekvensar eit tiltak har er også framheva av Høgsterett i Klimadommen (Høgsterett, 2020, avsnitt 182-183).

Er så rettssituasjonen i dag unødvendig lite føreseieleg i dei materielle spørsmåla? Fråværet av materielle prioriteringsverktøy som forvaltninga skal navigere etter, er påfallande. Samla plan vart som vi såg, oppheva. Kunnskapsgrunnlaget er under utvikling mellom anna gjennom systemet i vassforskrifta, men kompleksiteten i regelverket aleine kan nok likevel svekkja i kva grad ein opplever at rettssituasjonen blir meir føreseieleg.

Ein viktig føresetnad for å gi kommunane ei mindre viktig rolle i desse sakene var at areal- og interesseavklaringar skulle skje på regionalt nivå. Regionale planar har berre blitt utarbeidd i nokre få fylke, og gjennomslagskraft i konsesjonsprosessane synest variabel. Mogleg bruk av statleg plan, jf. pbl. \$6-4, i strid med arealbrukskategoriar kommunen tidlegare har vedteke, utfordrar også ideal om ein føreseieleg rettssituasjon.

Blir så konfliktnivået høgare som fylgje av ein lite føreseieleg rettssituasjon? Får vi fleire forvaltningsklager? Kan vi notere oss vegring frå 
utbyggjarsida? Dette er empiriske spørsmål som eg ikkje har undersøkt, men mitt inntrykk er at vi alt har sett slike verknader av det som kan oppfattast som ein lite føreseieleg rettssituasjon. Vi kan nok ikkje leggja skulda for all motstand i regelverket som er presentert her. Viktig framover er uansett å arbeida vidare med tiltak som gjer både dei materielle avvegingane og prosessane som styrer desse, meir føreseielege.

Kva meiner vi så med at retten skal vera rettferdig. Grunnleggjande er at alle er like for lova jf. Grl $₫ 98$. I eit klimaperspektiv er omsynet til komande generasjonar viktig, slik det også er uttrykt i Grl $\$$ 112. Mæhle og Aarli nemner at «[r]etten må for eksempel bidra til rettferdig fordeling av goder i form av samfunns- og naturressurser» (Mæhle \& Aarli, 2018, s. 107).

Denne dimensjonen av kva som blir oppfatta som rettferdige rettsreglar, kan hjelpa oss til å forstå at den ulike handsaminga av vasskraft- og vindkrafttiltaka når det kjem til fordeling av inntekter, i seg sjølv er eigna til å mobilisera vindkraftmotstanda landet over. Ei rettferdig fordeling vil i klimasamanheng også krevja at vi tenkjer over korleis handlingane våre i dag påverkar handlerommet til framtidige generasjonar. Behovet for ei rettferdig fordeling av gode, gjeld også naturen eller miljøet vårt, og dei negative verknadene av dei klimagunstige tiltaka slik som etablering av nye grøne energikjelder. Den som får eit vasskraftverk eller vindkraftverk plassert i sitt turområde eller utmarksområde, opplever jo dette nettopp som ei urettferdig plassering av naturinngrepet: Kvifor må vi tola dette her hjå oss? Eller som Jan Fridthjof Bernt spør: Byggjer avgjerda på ei generell norm som når alle omsyn er tekne med, synest rettferdig og rasjonell? (Bernt, 2004, s. 62). Artikkelen her svarar nok ikkje på dette spørsmålet, men eg har peika på nokre samanhengar som skaper tvil om normene på området alltid vil bli oppfatta som rettferdige og rasjonelle.

Vi kan også spørja om ikkje fråværet av overordna planar og eventuelt meir konkrete retningsliner er med på å gjera det vanskeleg for både utbyggjarar og talsmenn for motstridande interesser å oppfatta eller forstå om ein blir handsama på ein rettvis - lik måte for lova. Rettsleg autoritet krev demokratisk forankring (Mæhle \& Aarli, 2018, s. 102). Alle konsesjonar til fornybar energi blir tildelt etter lover vedtekne av Stortinget, og Grl $\$ 112$ vernar både om lokale miljøverdiar og klimaomsyn. Vi kan likevel 
spørja om graden av demokratisk forankring er tilstrekkeleg. Burde lovgivar, med kunnskap om kor påtrengjande klimaproblemet er, i større grad medverka til at forvaltninga synleggjer kva interesseavvegingar som føregår innanfor desse konsesjonsheimlane? I den nye vindkraftmeldinga er det som nemnt også teke til orde for at avvegingane må bli meir transparente (Olje- og energidepartementet, 2019, s. 35-36). Og er det mogleg å få til ei så god synleggjering av desse avvegingane at ulike interesser i større grad opplever at dei blir handsama på ein rettvis måte? Lovgivar meinte dessutan at konsesjonsprosessen etter desse lovene skulle skje i eit samspel med avveging av areal- og brukarinteresser i regionale planprosessar. I fråvære av eit slikt fungerande sampel kan ein seia at den demokratiske forankringa er redusert på to måtar. For det første fordi ein av føresetnadene frå lovgivar for å vedta lova har vist seg å ikkje stemma, og for det andre gjennom at regionale planar som blir vedtekne av demokratisk valde organ, ikkje har påverknad på statlege byråkratisk styrte konsesjonsprosessar.

\section{Litteraturliste}

Backer, I. L. (1984). Alta: Et utgangspunkt for lovendringer. I K. Haagensen \&

A. Midtun (Red.), Energi og samfunn. Kraftutbygging, konflikt og aksjoner (s. 165-193). Universitetsforlaget.

Backer, I. L. (2010). Naturmangfoldloven, Kommentarutgave. Universitetsforlaget.

Backer, I. L. (2012). Innføring i naturressurs og miljørett. Universitetsforlaget.

Backer, I. L. (2012). Integrasjonsprinsippet - er det noe bedre alternativ? I O. C.

Fauchald \& C. Voigt (Red.), Pro Natura. Festskrift til Hans Christian Bugge

(s. 42-62). Universitetsforlaget.

Backer, I. L. (2021). Plenumsdommen i klimasaken. Lov og rett, 3, 135-158.

Bernt, J. F. (2004). Normativisme og pragmatisme i rettsvitenskapen. Jussens Venner, 2, 61-73.

Bjørnebye, H. (2021). Spørsmålet om mangelfull utredning av klimavirkninger i

HR-2020-2472-P. Lov og Rett, 3, 159-178.

Bugge, H. C. (2019). Loerebok i miljøforvaltningsrett (5. utg.). Universitetsforlaget. Fauchald, O. C. \& Myklebust, I. (2019). Nedbygging av strandsona og Grunnlova $\$$ 112. I O. C. Fauchald \& E. Smith (Red.), Mellom jus og politikk, Grunnloven $\$ 112$ (s. 193-227). Fagbokforlaget. 
Fauchald, O. C. (2020). Adgangen til og prosedyrer for å fatte statlig planvedtak $i$ vindkraftsaker [Juridisk utredning til Aksjonsgruppa mot vindkraftutbygging på Faurefjell]. Fridjof Nansens Institutt.

Fauchald, O. C. (2021). Klima, vindkraft og miljø; hvordan balansere motstridende hensyn i lovverket? I H. C. Bugge (Red.), Klimarett: Internasjonal, europeisk og norsk klimarett mot 2030 (s. 591-615). Universitetsforlaget.

Holth, F. (2021). Plan- og bygningsloven. Vår viktigste klimalov? I H. C. Bugge (Red.), Klimarett: Internasjonal, europeisk og norsk klimarett mot 2030 (s. 408-432). Universitetsforlaget.

Jenkins, K., McCauley, D., Heffron, R., Stephan, H. \& Rehner, R. (2016). Energy justice: A conceptual review. Energy Research \& Social Science, 11, 174-182. https://doi.org/10.1016/j.erss.2015.10.004

Kroepelin K. og Bugge H.Chr. (2021). EUs klimarett og Norges klimaavtale med EU - en innføring. I H. C. Bugge (Red.), Klimarett: Internasjonal, europeisk og norsk klimarett mot 2030 (s. 293-323). Universitetsforlaget.

Mæhle, S. S. \& Aarli, R. (2018). Fra lov til rett (2. utg.). Gyldendal Juridisk.

Nygaard, N. (2004). Rettsgrunnlag og standpunkt (2.utg.). Universitetsforlaget.

Platjouw, F. (2021). EU og internasjonal miljørett av relevans for kystsoneforvaltning i Norge. I K. B. Hauge \& K. B. Stokke (Red.), Integrert kystsoneforvaltning, Planfaglege, samfunnsvitskaplege og juridske perspektiv (s. 52-68).

Winge, N. K. (2013). Kampen om arealene. Universitetsforlaget.

Salter, R., Gonzalez, C. G. \& Warner, E. A. K. (2018). Energy justice: Frameworks for energy law and policy. I R. Salter, C. G. Gonzalez \& E. A. K. Warner (Red.), Energy justice: US and international perspectives (s. 1-11). Edgar Elgar Publishing.

\section{Offentlege dokument}

NOU 1994: 12. (1994). Lov om vassdrag og grunnvann (vannressursloven). Næringsog energidepartementet.

NOU 2019: 16. (2019). Skattlegging av kraftverk. Finansdepartementet.

Klima- og miljødepartementet. (2014). Ny utslippsforpliktelse for 2030 - en felles løsning med EU (Meld. St. 13 (2014-2015)).

Miljøverndepartementet. (2007). Om lov om planlegging og byggesaksbehandling (plan-og bygningsloven) (plandelen) (Ot.prp. nr. 32 (2007-2008)).

Miljøverndepartementet. (2008). Om lov om forvaltning av naturens mangfold (naturmangfoldloven). (Ot.prp. nr. 52 (2008-2009)).

Bjerkestrand mfl. (2020). Konsesjonsprosessen for vindkraft på land. Beskrivelse, utfordringer og mulige tiltak (NVE rapport 3/2020). http://publikasjoner.nve.no/ rapport/2020/rapport2020_03.pdf 
Olje- og energidepartementet. (2015). Kraft til endring - Energipolitikken mot 2030 (Meld. St. 25 (2015-2016)).

Olje- og energidepartementet. (2021). Energi til arbeid - langsiktig verdiskaping fra norske energiressurser (Meld. St. 36 (2020-2021)).

Menneskerettsutvalet. (2011). Rapport til Stortingets presidentskap fra Menneskerettighetsutvalget om menneskerettigheter i Grunnloven. Dokument 16 (2011-2012).

Miljødirektoratet. (2019). Hva er Naturpanelet - IPBES? https://www. miljodirektoratet.no/globalassets/bilder/nyhetsdokumenter-old/nyhetervedlegg/faktaark-versjon-10.pdf

FN. (2019.) IPBES-rapporten. www.ipbes.net

Olje- og energidepartementet. (2019.) Vindkraft på land - Endringer $i$ konsesjonsbehandlingen (Meld. St. 28 (2019-2020)).

Miljøverndepartementet. (1984.) Om Samlet plan for vassdrag. (Meld. St. nr. 63 (1984-85)).

Miljøverndepartementet. (1986). Om Samlet plan for vassdrag. (Meld. St. nr. 53 (1986-87)).

Miljøverndepartementet. (1991). Om Samlet plan for vassdrag. (Meld. St. nr. 6o (1991-92)).

Kommunal- og forvaltningskomiteen. (2018). Om oppgaver til nye regioner (Innst. 119 S (2018-2019)).

Klima- og miljøverndepartementet. (2015). Veiledning til bruk av vannforskriften $\$ 12$ (Brev sendt frå Klima og Miljødepartementet, 23.02.2015). Brevet er utarbeidd av Klima- og Mijøverndepartementet i samarbeid med Olje- og energidepartementet, Nærings- og fiskeridepartementet, Samferdselsdepartementet, Landbruks- og matdepartementet og Kommunal og moderniseringsdepartementet.

Klima- og miljøverndepartementet. (2016). Lov om klimamål (klimaloven). (Prop. 77 L (2016-2017)).

Klima- og miljøverndepartementet. (2017). Brev sendt frå Klima og Miljødepartementet, 31. mars 2017, Retningslinjer for innsigelsespraksis i energisaker.

Klima- og miljøverndepartementet. (2020). Klimaplan for 2021-2030. (Meld. St. 13 (2020-2021)).

Kommunal- moderniseringsdepartementet. (2018). Endringen i plan- og bygningsloven m.m. (håndtering av overvann i arealplanlegging $m v$.) (Prop.32 L (2018-2019).

Skatteetaten. (2021, 22. juni). Høring - avgift på landbasert vindkraft [Brev]. 


\section{Rapportar}

Hagen, D., Eide, N. E., Evju, M., Gundersen, V., Stokke, B. G., Vistad, O. I., RødEriksen, L., Olsen, S. L. \& Fangel, K. (2019). Håndbok. Sårbarhetsvurdering av ferdselslokaliteter $i$ verneområder, for vegetasjon og dyreliv (NINA Temahefte 73.) Norsk institutt for naturforskning.

Wiig, H., Tesli, A., Stokstad, S. \& Hansen, G. S. (2019.) Intensjoner og praksis for regionale planer for vindkraft. -Hvilken rolle kan fylkeskommunene ha $i$ vindkraftforvatningen? (NIBR-rapport 2019:4).

Fauchald, O. C. (2018). Konsesjonsprosessen for vindkraftutbygginger - juridiske rammer (FNI-rapport 1/2018).

Fauchald, O. C. (2020). Unntak fra plikten til å utføre miljøkonsekvensutredning i lys av EØS-retten (FNI-rapport 2020:3).

Havs- och vatten myndigheten. (2016). Följder av Weserdomen, Analys av rättslaget med sammanställning av domar (2016:30).

\section{Lover og andre reglar}

Grunnlova. (1814). Kongeriket Noregs grunnlov (LOV-1814-05-17). Lovdata. https:// lovdata.no/lov/1814-05-17-nn

Energilova. (1990). Lov om produksjon, omforming, overføring, omsetning, fordeling og bruk av energi m.m. (LOV-1990-06-29-50). Lovdata. https://lovdata.no/lov/ 1990-06-29-50

Klimaloven. (2017). Lov om klima (LOV-2017-06-16-60). Lovdata. https://lovdata. no/lov/2017-06-16-6o

Miljøinformasjonslova. (2003). Lov om rett til miljøinformasjon og deltakelse $i$ offentlige beslutningsprosesser av betydning for miljøet (LOV-2003-05-9-31). Lovdata. https://lovdata.no/lov/2003-05-09-31

Produktkontrollova. (1976). Lov om kontroll med produkter og forbrukertjenester (LOV-1976-06-11-79). Lovdata. https://lovdata.no/lov/1976-06-11-79

Vannfallrettighetsloven. (1917). Lov om konsesjon for rettigheter til vannfall $m v$. (LOV-1917-12-14-16). https://lovdata.no/lov/1917-12-14-16

Vannforskriften. (2006). Forskrift om rammer for vannforvaltningen (FOR-2006-1215-1446). Lovdata. https://lovdata.no/forskrift/2006-12-15-1446

Vassdragsreguleringsloven. (1917). Lov om regulering og kraftutbyrring $i$ vassdrag (LOV-1917-12-14-17). Lovdata. https://lovdata.no/lov/1917-12-14-17

Plandirektivet. (2001). Plandirektivet: miljøkonsekvensvurderinger av planer og programmer Direktiv 2001/42/EF Miljøvirkningsdirektivet. 
Prosjektdirektivet. (2011). Prosjektdirektivet: Direktiv 2011/92/EF om vurdering av visse offentlige og private prosjekts miljøverknader, seinare endra ved direktiv 2014/52/EU.

Vassrammedirektivet. (2000). Direktiv 200o/60/EF.

\section{Retningsliner}

Kommunal og moderniseringsdepartementet. (2018). Statlege planretningslinjer for klima- og energiplanlegging og for klimatilpassing. Forskrift 28.09. 2018 nr. 1469 i medhald av plan- og bygningslova $\$ 6-2$.

Kommunal og moderniseringsdepartementet. (2021). Statlige planretningslinjer for differensiert forvaltning av strandsonen langs sjøen. Fastsatt ved kgl. res. av 28. mai 2021 i medhald av plan- og bygningslova $\$ 6-2$. https://www.regjeringen.no/no/ dokumenter/differensiert-forvaltning-strandsonen/id636763/

Miljøverndepartementet. (2007). Retningslinjer for planlegging og lokalisering av vindkraftanlegg. (T-1458/2007). https://www.regjeringen.no/no/dokumenter/ retningslinjer-for-vindkraft/id472954/

\section{Konvensjonar}

Den europeiske landskapskonvensjonen (Cets No. 176)

Bernkonvensjonen av 19. september 1979

Ramsarkonvensjonen av 2. februar 1971

\section{Dommar}

EU-domstolen, C-671/16

EU-domstolen, Østerrike mot kommisjonen, C-364/14 Schwarzer Sulm

EU-domstolen, C-461/13 Weser

Dom frå Borgarting lagmannsrett avsagt 23. januar 2020

Høgsterett, Staten mot Natur og Ungdom mfl., HR-2020-2472-P

Høgsterett, Fosen Vind DA og Staten (som hjelpeintervenient) mot Sør-Fosen sitje og Nord-Fosen Siida, HR-2021-1975-S

\section{Nettside frå organisasjonar}

NVE. (2020, 23.04.2019) 1986: Samla plan for vassdrag. Henta frå www.nve.no.

EU. (2019). Henta frå https://ec.europa.eu/info/strategy/priorities-2019-2024/ european-green-deal_en 
Stortinget. (2020). Voteringsoversikt over forslag nr. 4 frå Arbeiderpartiet, SV og MDG. Henta frå https://www.stortinget.no/no/Saker-og-publikasjoner/Saker/ Sak/Voteringsoversikt/?p=80343\&dnid $=1$

Stortinget. (2020). Vedtak i korthet. https://www.stortinget.no/no/Saker-ogpublikasjoner/Saker/Sak/Voteringsoversikt/?p=80343\&dnid=1

\section{Elektronisk leksikon med forfattar}

Vinvar, A. \& Rosvold, K. A. (2018, 15. januar). Samlet plan for vassdrag. I Store norske leksikon. https://snl.no/Samlet_plan_for_vassdrag 



\title{
Menneske og dyr i grenseland - om rettar, rettferd og rett ferd iutmarka
}

Frode Flemsæter

Ruralis - Institutt for rural og regionalforsking

Katrina M. Brown

The James Hutton Institute

\begin{abstract}
In this chapter, we examine how people and animals have co-created borders, land rights and practices in outfields (utmark) in Norway. Further, we examine how this plays a part when change and increasing diversity is managed. We do this by examining conflicts arising between farmers, landowners and reindeer herders in Norway, resulting from policy imperatives towards agricultural diversification. We find that different stakeholders with rights that are relevant in this context may have different capacities to respond when valuations of outfield resources change, and that the human-animal relations in reindeer herding are having a particular impact on these capacities. We argue that the current regulatory system negotiating the interests of different stakeholders with rights struggles to comprehend or deal with issues of animal agency and mobility in reindeer-herding practices. We propose that Haraway's concept of response-ability can be useful to help make more-than-human agency more visible, and therefore better accounted for, in the unsettling and resettling of property relations in the Norwegian outfields. This allows us to understand more precisely how human-animal relations, in our case relations between reindeer and reindeer herders, affect the responses available to the various stakeholders when land and land-use rights in the outfields are negotiated.
\end{abstract}

Keywords: borders, animals, rights, justice, space

Sitering: Flemsæter, F. \& Brown, K. M. (2021). Menneske og dyr i grenseland - om rettar, rettferd og rett ferd i utmarka. I F. Flemsæter \& B. E. Flø (Red.), Utmark i endring (Kap. 7, s. 191-211). Cappelen Damm Akademisk. https://doi.org/10.23865/noasp.151.ch7

Lisens: CC BY-NC-ND 4.0 


\section{Innleiing}

Grenser teikna på kart og skildra i tilhøyrande dokument er kanskje det mest brukte verktøyet i moderne arealforvaltning - for å regulere og styre aktivitet, og for å halde orden på ein elles komplisert røyndom. Men grenser kan vere så mangt. Spør vi Store norske leksikon (2021), så er grense ei linje som skil eit område frå eit tilstøytande område. Det høyrest både tilforlateleg og praktisk ut. Men så lenge det er menneske som har trekt grenselinjene, kan dei stillast spørsmål ved, diskuterast og flyttast. Grenser kan vere fysiske, dei kan være opplevd eller dei kan vere konstruert for eit bestemt formål. Nokre typar grenser er det juridisk kraft i, medan andre er symbolske. Grenser er ein forvaltningsreiskap, dei identifiserer oss og dei strukturerer rettane våre, kven vi samhandlar med, og kven vi byggjer fellesskap med. Og som historia har vist oss - kven vi kjem i konflikt med.

Grenser og grensedragingar blir meir komplisert når vi går frå det universelle og abstrakte mot det konkrete. Så lenge det er ei lita gruppe menneske som styrer kvar grensa skal gå, så kan grensedragingar vere temmeleg rett fram. Det var ikkje måte på kor «rett fram» det var for kolonimaktene å trekkje grenselinjer med kart og linjal i Afrika og Nord-Amerika så lenge dei som budde der frå før, ikkje vart tekne med på råd. Fullt så rett fram er det ikkje å følgje elveløp, fjordar og fjell, men topografien har ofte vore utgangspunkt for funksjonelle og kulturelle grenser, og etter kvart administrative grenser, mellom land, kommunar eller grender. Vanskeleg blir det når menneske er ueinige om kor grensa skal gå, og enda meir innfløkt blir det når vi òg tek mål av oss å forvalte dyr og planter ved hjelp av grenser. Da er vi nøydde til å halde oss til dei til dels nokså flytande grensene dei ulike artane praktiserer, sjølv om vi gjer vårt beste for å trekkje grenser rundt dei - anten det er ulv, reinsdyr eller raude- og svartelisteartar. «Grenselaust» krevjande blir det når grenser som er avgjerande for folk sine eigedommar og rettar, er skapt på grunnlag av eit samspel mellom menneske og dyr sin skiftande og fleksible arealbruk.

I dette kapittelet skal vi sjå nærare på nettopp dette - korleis grenser og tilhøyrande rettar kan vere skapt gjennom eit samspel mellom menneske og dyr, og vidare korleis dette kompliserer grensedragingar som vi gjerne 
ønskjer å gjere for å handtere endringar og mangfald i utmarka. Spesielt skal vi ta for oss korleis samspelet mellom dyr og menneske verkar på folk sitt høve til å respondere på endra verdsetting av utmarksressursar og tilhøyrande forvaltningspraksisar. Utgangspunktet vårt er forsking vi har gjort på møtet mellom den sør-samiske reindrifta og ei rekkje andre utmarksbrukarar og interessentar i den midt-norske utmarka.

\section{Endra utmarksferd}

Utmarka har i hundrevis av år vorte sett på som ein utvida del av gardsbruka og inngått som ein viktig del av bondefamiliane sin hushaldsøkonomi. Utmarka er definert i friluftslova (1957) som alt som ikkje er innmark. Det vil seie det aller meste av areal som ikkje er bygd på eller dyrka. Innmarka ligg tett til garden, innramma av klare grenser, og innanfor desse grensene kontrollerer eigarane i stor grad ressursane på eigedommen slik dei vil. I utmarka derimot, har ein på ulike vis organisert seg slik at fleire har hatt tilgang til å utnytte ressursar på dei same areala, uavhengig av kven som eig grunnen. I utmarka kan ulike folk ha bruksrettar til eksempelvis sauebeite, reinbeite, fiske, jakt, sanking, skogsdrift, uttak av ved og friluftsliv, nærast side om side. Men når «tida og tilhøva», som det står i fjellova, ${ }^{1}$ endrar seg, så blir det eksisterande både bruken og brukarane - utfordra.

I dei siste par tiåra har nemleg utmarka vorte verdsett på stadig nye måtar. Stadig fleire aktørar interesserer seg for utmarka, samstundes som mykje av den etablerte utmarksbruken framleis held stand. Ein kan seie at det i den seinare tida har gått føre seg ei relativt storstilt kommodifisering - varegjering - av den norske utmarka (Flø, 2011; Rønningen \& Flemsæter, 2016). Utmarksressursar blir altså på ulike måtar omgjort til ei vare. Ei slik varegjering kjem ifølgje filosofen Steven Best (1989) i tre ulike former. Den første forma for varegjering av ein ressurs er når bytteverdien overstig bruksverdien. Eit eksempel på dette er når beiteressursen går over frå å nyttast til å produsere mat til eige bruk til å produsere ei

1 Lov om utnytting av rettar og lunnende m.m. i statsallmenningane (fjellova). https://lovdata.no/ dokument/NL/lov/1975-06-06-31 
matvare for sal. Den andre forma er når folk konsumerer omgjevnadar som andre har laga - når beitelandskapet blir ei verdifull kulisse for folk som bur i lokalsamfunnet, eller for dei som bruker utmarka til rekreasjon. Den tredje forma for varegjering er når det er representasjonen, ikkje materialiteten, som blir tillagt verdi. Medan materialiteten er handfast og fysisk, så er representasjonen måten vi framstiller noko på. For eksempel gjennom bilde eller tekst. Så når vi tek eit bilde av oss sjølve i beitelandskapet og legg dette ut i sosiale medium for å framstille oss på ein bestemt måte, så er det representasjonen, framstillinga, som blir tillagt verdi. Sjølv om vi for så vidt kan sjå ei tidslinje gjennom desse formene for varegjering frå mange hundre år gamal beitebruk til dagens postar på Instagram, så er det samstundes slik at alle tre formene gjer seg gjeldande når vi ser på korleis utmarksressursane blir utnytta i dag.

Denne varegjeringa av utmarksressursar er ei sterk drivkraft for mykje av den utviklinga vi ser i utmarka (Flø, 2011; Rønningen \& Flemsæter, 2016, sjå òg introduksjonskapittelet til denne boka). Hyttebygging, energiproduksjon og eit endra friluftsliv er mellom anna eksempel på dette. Som forskarar har vi følgt med på utmarksbruk og utmarksforsking over ei tid, og ein observasjon vi har gjort oss, er at det i takt med den utvida og endra utmarksbruken ser ut som om behovet for grenser - behovet for å skilje deg frå meg, ditt frå mitt og ein ressurs frå ein annan - er aukande. Det har vore bytesteinar og -tre i utmarka i uminnelege tider, men no er det mange som ferdast rundt i utmarka og leitar etter krysset i storfurua og skrapar mose av store steinar som stikk opp frå lyngen. For med kommodifiseringa av utmarka har utmarksgrensene fått auka merksemd og ny verdi, og da oppstår det gjerne eit behov for å trekkje nye grenser eller fornye dei gamle.

Desse observasjonane, og nysgjerrigheita som dei vekte, var grunnen til at ei gruppe forskarar for nokre år sidan etablerte eit forskingsprosjekt $^{2}$ der vi ville ta ein tur utanfor skigarden i den midt-norske utmarka. Reindrifta har vore ein sentral utmarksbrukar over store areal i lang,

2 «Reindrift og kommodifisering av utmarka i sørsamiske områder - hvordan etablerte rettigheter og praksiser blir utfordret» (Rural Rein). Prosjektet vart leia av Ruralis og finansiert av Norges forskningsråd (prosjektnr. 199365). Andre relaterte publikasjonar frå prosjektet er Rønningen \& Flemsæter, 2016 og Brown et al., 2019. 
lang tid, og det er ei næring som kjem i inngrep med og i vesentleg grad blir påverka av annan utmarksbruk. Vi meinte at med å studere utmarka med utgangspunkt i ei så arealkrevjande næring som reindrifta, så ville vi kunne dekkje mange ulike aspekt av utmarksbruk og -forvaltning. I forskingsprosjektet studerte vi derfor ny og fornya utmarksbruk i Midt-Noreg og spenningane dette har ført med seg i høve til den sørsamiske reindrifta. Måten vi gjekk fram på, var først og fremst å intervjue brukarar og forvaltarar av utmarka om sitt forhold til og sitt syn på utmarka. I alt vart dette 22 interessante samtalar med representantar for både reindrifts- og bondenæringa, samt representantar frå landbruksforvaltninga, inkludert reindriftsforvaltninga, på lokalt, regionalt og statleg nivå. ${ }^{3}$ Gjennom desse intervjua fekk vi eit godt innblikk i den faktiske utmarksbruken, korleis bruken blir oppfatta av ulike aktørar, og korleis bruk, endra bruk og interessekonfliktar blir handtert av forvaltningsaktørane. I tillegg til desse intervjua har vi studert ei rekkje politiske dokument frå dei siste tiåra, om landbrukspolitikk, utmarksforvaltning og reindrift, og vi har følgt mediedebatten. Det empiriske materialet i dette kapittelet er henta frå dette forskingsprosjektet, ${ }^{4}$ og i teksta vil vi vise til sitat både frå intervjua og frå dokument vi har studert.

\section{Utmarksrettar og høve til å respondere på endring}

Samfunn har til alle tider laga system rundt eigedoms- og bruksrettar. Slike system formar relasjonane som vi menneske har til omgjevnadane våre gjennom å regulere og avgrense kven som kan utnytte og kontrollere bestemte ressursar. Dei regulerer òg kven som må ta byrdene og kostnadane med ressursbruken. I eit samfunn der verdien folk ser i ein og same ressurs både er ulik og endrar seg over tid, så er systema vi har

3 Alle vart intervjua i kraft av ei rolle som representant for anten ein forvaltningsinstitusjon, interessegruppe eller rettshavarar. Vi opplyste derfor om at full anonymitet ikkje kunne lovast, men at vi uansett ikkje skulle bruke namna deira i publikasjonane.

4 Sjølv om empirien er henta frå prosjektet Rural Rein (sjå fotnote 2), er refleksjonane og analysane i kapittelet vidareutvikla i det pågåande forskingsprosjektet Norsk utmark i endring: Mellom tradisjonelt landbruk, moderne konsum og grønn industrialisering (Govout). Dette prosjektet er òg leia av Ruralis og finansiert av Norges forskningsråd (prosjektnr. 303303). 
rundt eigedoms- og bruksrettar, til ei kvar tid gjenstand for vurdering, revurdering og dragkampar (Macpherson, 1978). Når verdien ein ser i ressursar, som utmarksressursane, blir endra, ja, så endrar ein ikkje berre korleis ein held seg til landskapet dei er ein del av, men òg korleis ein ser på rettane til ressursane. Det veks fram nye måtar å gjere ting på - nye praksisar - og desse kan kome i konflikt med andre grupper med andre praksisar og behov i det same landskapet.

Mange samfunnsforskarar har den seinare tida bevega seg i dette landskapet der synet på ressursar, bruk og rettar endrar seg, og endrar seg ulikt hos ulike grupper. Fleire av desse forskarane har peikt på kor viktig samspelet mellom menneske og dei fysiske omgjevnadane våre er for landskapet og landskapsbruken. Og ikkje minst har dei gjort oss merksame på korleis dette samspelet formar forholdet mellom menneske, og at dermed landskapet kan både forme, halde ved like og endre sosiale relasjonar, og slik skape både rett og urett (Peil \& Jones, 2005 Mitchell 2003; Flemsæter, et al., 2015). Blomley, som har vore ein pioner innanfor det som er kalla rettsgeografien, meiner at mange av konfliktane rundt eigedom og rettar botnar i ei spenning mellom å sjå det geografiske rommet rundt oss, og dermed også eigedom, som absolutt eller som relasjonelt (Blomley, 2013). Forstår vi rommet rundt oss som absolutt, så er dette noko som er målbart og asosialt, og lett å objektivere gjennom å trekkje grenser rundt. Da blir areal og ressursar lett skilt frå andre økologiske eller sosiale einingar. Derimot, forstår vi rommet rundt oss som relasjonelt, så er relasjonane mellom menneske, og, som vi peikar på i dette kapittelet, relasjonane mellom dyr og menneske heilt avgjerande for korleis ein held seg til eigedom og rettar - og til grenser. Landskap og eigedom blir da produsert og reprodusert gjennom sosiale relasjonar. I sine relativt nylege studiar av korleis samspelet mellom dyr og menneske blir spegla, eller ikkje, i lovverket har Ojalammi og Blomley (2015) og Braverman (2015) etterlyst ein betre måte å ta høgde for nettopp dyr si rolle i denne produksjonen og reproduksjonen av eigedom og rettar.

I denne samanhengen kan det vere verd å bryne seg litt på omgrepet som Donna Haraway har utvikla og skrive om i ulike samanhengar: response-ability (Haraway, 2008). Omgrepet spelar sjølvsagt på ordet responsibility, altså ansvar, men med å vri på ordet på denne måten peikar 
ho på at ikkje alle har same høve til å ta ansvar - ikkje alle har same høve, kapasitet eller evne til å respondere på endringar rundt seg. Da hjelper det kanskje ikkje så mykje å seie at ein på papiret har rett til både å utforme prosessar og delta i dei. For vi er alle i ulik stand til å respondere, reagere og aksjonere på det som skjer rundt oss - vi er i ulik stand til å ta ansvar. Dette gjeld menneske så vel som dyr. Og ikkje minst gjeld det når menneske og dyr lever og agerer i tett samspel.

Haraway sitt response-ability-omgrep har for eksempel vorte bruka til å kaste lys over korleis samspelet mellom dyr og menneske i friluftslivet, anten det er mellom hund og eigar eller mellom friluftslivsutøvarar og ville dyr, er det som skaper det handlingsrommet ein har å halde seg til når friluftslivet endrar seg og konfliktar oppstår (Brown, 2015; Brown \& Dilley, 2012). Haraway sitt omgrep kan vere ein nøkkel til forståing når det gjeld korleis menneske og dyr har høve, eller manglande høve, til å uttrykkje, tilpasse seg og respondere til kvarandre.

Vi skal no ta med desse tankane over til den norske utmarka, nærare bestemt til dei sør-samiske områda i Midt-Norge. Her møter den sørsamiske reindrifta ei rekkje andre utmarksinteresser, og utmarksforvaltninga er på leit etter gode verktøy for å styre rettar, rettferd og rett ferd i eit landskap som både er relasjonelt, jf. Blomley (2013) og konfliktfylt. Korleis ein rettar inn systemet som skal regulere utmarka, og kva for verktøy ein tek i bruk for å styre og kontrollere ressursbruk, er avgjerande for korleis fordelinga mellom fordelar og ulemper, inntekter og kostnadar, fridom og avgrensing spelar seg ut.

\section{Sør-samisk reindrift}

Sør-samane er ei minoritetsgruppe innanfor den samiske minoriteten. Dei har eit eige språk som no er trua, og ein kultur som er tett knytt til reindrifta. Reinen treng store areal og ein fleksibel bruk sidan den har sesongvariasjonar i beitebruken. Reindrifta utgjer ein heilt sentral grunnstein for sør-samisk kultur og språk, det er ei viktig næring, men òg ein viktig identitetsmarkør. Rettane til å drive reindrift er opparbeidd gjennom bruk over lang, lang tid, mykje etter same prinsipp som andre beiterettar (Bull, 2001; Ravna, 2019). Det her er altså ikkje ein rett dei har på 
grunn av at dei er samiske, det er ein rett som er utvikla gjennom alders tids bruk. Bruken er på si side definert, og avgrensa, gjennom eit tett samspel mellom menneske, reinen, vegetasjon, rovdyr, klima og topografi. Eit samspel som endrar seg frå år til år, og frå tiår til tiår. Reindriftslova stadfestar at sør-samane har rett til å utøve reindrift basert på «alders tids bruk» (\$4). Både Kirsti Strøm Bull (f.eks. 2010) og Øyvind Ravna (f.eks. 2005; 2019) har peika på korleis reindrifta sine bruksrettar til tider, og av somme, har vorte oppfatta som «tålt bruk» framfor å vere rettar på lik linje med andre bruks- og grunnrettar. Ravna (2005, s. 618-619) skriv for eksempel at

... selv om Høyesterett har fastlagt at reinbeiteretten er en rettslig beskyttet bruksrett, noe som også er nedfelt i reindriftsloven $₫ 9$, så har praksis vist at reinbeiteretten i mange sammenhenger er blitt sett på som en vikende rett som har måttet ta til takke med de ressursene grunneiere og jordbrukere ikke har behov for.

Gjennom å ha følgt utmarkdebatten over tid så slår det oss at det ofte synes som om mange oppfattar at grunneigarretten står generelt sterkare enn bruksretten i utmarka, så det er ikkje sikkert at ei tilsynelatande aukande favorisering av arealbruksinteresser basert på grunneigarretten framfor bruksrettar berre har med reindrifta å gjere. Kanskje kan dette vere del av ein trend der ein går frå ei kollektiv til ei meir individuell orientering i ressursutnyttinga (jf. kapittel 1 i denne boka).

Rettane til reindriftssamane er tett knytt til reinen si åtferd og arealbruk, og dei er slik både etablert og skjøtta gjennom samspelet mellom folk og dyr. Rettane er altså skapt like mykje på grunnlag av dyra sine behov som av folk. Men reinen sine behov og si åtferd, og dermed rettane til å drive reindrift, er ikkje nødvendigvis kompatible med kommodifisering og ny og fornya verdsetting av utmarksressursane. Hyttebygging, energiproduksjon og eit aukande og delvis endra friluftsliv legg press på reinens naturlege levesett og dermed òg arealbruken og arealbehovet til reindrifta (Risvoll \& Hovelsrud, 2016). Sumeffektane av fragmentering og tap av areal kan skape eit auka behov for å transportere reinen over lange avstandar mellom sommar- og vinterbeite, noko som både er kostbart og arbeidskrevjande, og i strid med reindriftslova (reindriftsloven 
$\$ 22$ ). Andre stader har barrierar skapt av ulike utbyggingar leia reinen inn på andre trekkruter der nye konfliktar har oppstått i møte med andre utmarksbrukarar.

Rettane er altså definert ut frå reinen sine behov, men når rettane så skal handhevast eller regulerast i møte med andre utmarksinteresser, er det, som vi no skal sjå, mest mogleg fastlagte grenser mange heller vil gripe fatt i. Det skaper problem.

\section{Ta garden i bruk}

I utmarka har ein organisert seg slik at fleire har tilgang til å utnytte ressursar på dei same areala. Forankra i eigedom, sedvane eller lovgiving kan ulike folk ha ulike rettar til ulike ressursar. I eit såkalla substansielt eigedomssyn har eigar full og eksklusiv råderett over ressursane på eigedommen. Klart definerte grenselinjer rammar inn eigedommen, og andre sin aktivitet innanfor desse grensene er å betrakte som eit inngrep i eigedomsretten. I eit praktisk-funksjonelt eigedomssyn derimot, markerer grenselinjer eit område der fleire kan ha ulike rettar gjennom kløyvd eigedomsrett (Robberstad, 1963). Ein kan litt forenkla seie at mens eigarskapet til innmarka no i stor grad er praktisert i tråd med eit substansielt eigedomssyn der eigaren har stor grad av kontroll over alle ressursane, så har utmarksbruken, i alle fall til no, i det store og heile vorte praktisert etter eit praktisk-funksjonelt eigedomssyn der det meir har vore snakk om å tilpasse bruken sin i høve til andre brukarar av det same området.

Men jordbruket kastar ikkje nødvendigvis av seg så mykje, og i lengre tid har gardbrukarar vorte oppfordra til å vere kreative og nytenkjande når det gjeld å skaffe inntekt frå garden sine ressursar. Som ein representant frå Fylkesmannens landbruksavdeling som vi intervjua sa:

... landbrukspolitikken [...] gjer at landbruket må sjå utover skigarden for å

kunne livberge seg

Og nettopp det har mange grunneigarar i landbruket gjort, og i takt med dette har interessa for og bruken av utmarka endra seg. For å forstå litt meir av bakgrunnen for desse endringane vil vi først gå eit par tiår tilbake, og henge oss opp i eit par sitat frå Stortingsmeldinga frå 1999/200o - Om 
landbruk og matproduksjon (St.meld. nr. 19. (1999-200o), s. 18): Der blir det mellom anna oppmoda til at grunneigarar skal

... ta i bruk en større del av ressursgrunnlaget på landbrukseiendommen

gjennom blant anna

...økt næringsmessig utnyttelse av utmarka

Det er neppe Stortingsmeldinga og påøølgjande politikk under dåverande landbruksminister Lars Sponheim som åleine har styrt utmarksbruken sidan årtusenskiftet, men det er nettopp ei slik utvikling vi har fått. Utmarka har fått ny og fornya ressursbruk, og grunneigarane har gradvis utvida ressursbruken og søkt å ta kontroll over fleire av ressursane gjennom for eksempel hyttebygging, tilrettelegging for friluftsliv og småkraftanlegg, ofte i samarbeid med andre aktørar. I den nemnde Stortingsmeldinga (s. 120) skriv departementet at konfliktar mellom ulike brukarinteresser i utmarka ikkje er uvanleg, og at med auka næringsverksemd i utmarka, slik meldinga legg opp til, er det:

... påregnelig at hyppigheten av slike konflikter kan øke.

Tek vi ein tur ut i utmarka, eller til avisspaltene, så ser det ut til at denne spådommen slo til. Det har vore strid om utmarka tidlegare òg, ikkje minst knytt til samisk reindrift, men med utvida bruk og fleire aktørar er det liten tvil om at striden i og om utmarka i alle fall ikkje har vorte mindre etter denne stortingsmeldinga. Så kva er det desse spenningane dreier seg om? Og ikkje minst, kvifor oppstår dei, eigentleg? Vi skal prøve å kaste i alle fall noko lys på det siste med å sjå på sør-samisk reindrift sitt møte med ny og aukande utmarksbruk. Men først vil vi reflektere litt over tre diskursive element, som ein seier på forskarspråket, i sitata frå denne stortingsmeldinga. Desse diskursive elementa er altså ord og vendingar som legg premiss for den vidare samtalen. Det ligg ei makt i språket som ein ikkje nødvendigvis ser før ein stoppar opp, ser seg tilbake, og tenkjer over samanhengen mellom tankesett, språket og korleis dette blir omsett i praksis.

Først; med å inkludere utmarksressursane som ein del av ressursgrunnlaget på landbrukseigedommen, utan ei nærare klargjering, er det fort at utmarka, i språkleg forstand, smett innanfor gjerdet der eit 
eigedomssyn basert på individuelle og eksklusive rettar, slik som på innmarka, herskar. Utmarka kan her oppfattast som ei utviding av innmarka heller enn eit areal der ein har rettar som følgje av innmarkseigedommen. Dette er ei form for territorialisering (jf. Blomley, 2019), og kan av nokon òg oppfattast som ei ny-kolonisering (Fjellheim, 2016), i den forstand at oppfatningar om privat og individuelt eigarskap gradvis lek inn på areal der rettar tradisjonelt har vorte utforma etter eit prinsipp om kløyvde og kollektive bruksrettar. Ved å ta i bruk eit språk som flyttar grenser på denne måten, både i konkret og overført forstand, blir det gitt grønt lys for å sjå som sitt eige noko som tidlegare var delt.

Vidare; ordet «ta» peikar mot ein fridom til å tileigne seg noko, utan at det blir stilt vidare spørsmål ved det. Når det gjeld problemet ein då støyter på, at ein tek noko frå nokon, så er det skjult bak vendinga «i bruk». Bak invitasjonen til «å ta i bruk» utmarksareal ligg det underforstått at arealet ikkje er i bruk frå før, eller at det i alle fall er underutnytta. Å definere noko som ubrukt eller underutnytta er ifølgje den politiske filosofen John Locke ein viktig del av taktikken bak appropriering - altså det å leggje hevd på ein ressurs gjennom bruk og dermed skaffe seg eigarskap over ressursen (Locke, 1978). Oskal (Bull, Oskal \& Sara, 2001) skriv om korleis Locke sine tankar om appropriering har gjort seg gjeldande i det samiske landskapet der areal som ikkje er nytta til jordbruk, av andre enn reindriftssamane gjerne har vorte sett på som «ikkje nytta land». Det er heller ikkje lenge sidan dåverande sametingspresident Aili Keskitalo snakka til NRK kor oppgitt reindriftssamane stadig blir over å høyre kritiske røyster om alt det «unytta» arealet som reindrifta på død og liv skal hegne om (NRK, 2014). Når ein først har fått definert noko som unytta, så står det berre att å trekkje grenser mot tilstøytande område, som det stod i leksikonet, før approprieringa kan seiast å vere fullbyrda og ressursen er klar til å nyttast.

\section{Grenser, kommodifisering og sør-samisk reindrift}

Når ein så vil «ta heile landbrukseigedommens ressursar i bruk», og kommodifisere utmarka, som for eksempel ved å byggje hyttefelt, produsere vass- og vindenergi, utvinne mineral - ja da oppstår det ofte konflikt. Og 
konfliktar, dei har vi behov for å løyse eller aller helst unngå. Og måten vi unngår konfliktar på er å vere framsynte og planleggje godt. Og når vi planlegg arealbruk, da er gjerne kartet godt å ty til. Og kva anna er eit kart enn eitt sett med grenser. Som skil eitt frå anna, og mitt frå ditt. Gjennom planlegging søkjer vi å finne den optimale grensa og tilhøyrande skrankar. Sjølv om arealplanlegginga gjennom dei siste tiåra har fått stadig meir fokus på samhandling og deltaking (Sager, 1994; 2018), så har desse konsensus-orienterte prosessane i liten grad vore i stand til å handtere konfliktar. Å skape konsensus rundt ei grense eller eit sett med reglar har vore viktigare enn å skape arenaer for samhandling der planlegging er ein kontinuerleg prosess, og der kartet i større grad kan endrast i takt med eit omskifteleg terreng (Skjeggedal et al., 2020).

Med det mål å finne gode grenselinjer mellom ulik utmarksbruk har ein strategi frå styresmaktene vore å få reindrifta til å identifisere og kartleggje areal og ruter i landskapet av spesiell interesse og viktigheit. Landbruksdirektoratet har leia dette arbeidet, og på nettsidene sine (Landbruksdirektoratet, 2020) skriv direktoratet at:

Reindriftas arealbruk er tilpasset skiftende naturgitte forhold og samfunnsmessige endringer. Det lar seg derfor ikke gjøre å kartfeste alle sider av reindriftas arealbruk på en helt nøyaktig måte. [...] Et tilgjengelig, konsistent og oppdatert reindriftskart er helt grunnleggende for dets verdi som planleggings- og beslutningsgrunnlag.

Det blir oppmoda til å synleggjere og verdsette ulike område, slik at ein kan skilje viktige område frå mindre viktige når arealbruk skal planleggjast og avgjerast, og at ein dermed kan planleggje anna aktivitet utanfor det som blir kartfesta til å vere viktigast. Sjølv om styresmaktene altså anerkjenner at reindrifta finn det vanskeleg å kartleggje arealbruken, og at reindriftskarta ikkje formelt sett er knytt til bruksrettane til reindrifta, så er like fullt dette eit heilt sentralt verkemiddel det blir tydd til for å løyse utfordringane med interesse- og arealbruksmotsetningar. Det her er andre brukargrupper òg oppfordra til å gjere, og til saman skal det her gi den inputen som moderne planverktøy er avhengig av. Som ein representant frå miljøverndepartementet sa i eit intervju: 
Det er masse ting knyttet til moderne planlegging som, som ikke umiddelbart blir sett på som greit (fra reindrifta sitt hold). Altså det å vise arealmessig på kartet (...), det å synliggjøre ting (...) det strider litt mot noen oppfatninger av hva som er riktig å gjøre da. (...) og det er veldig langt i fra en sånn rasjonalistisk planleggingsmodell som vi mer eller mindre opererer med.

De vil ikke vise det på kartet. Og det gjør jo at næringen kan bli litt sånn taper i et, i et sånt moderne samfunn hvor alt er på data, alt synliggjøres og du legger ting oppå hverandre og lissom, og hvis de er helt på siden av det så ...

Så det er metodikken med å synliggjøre ting, ja det å vise hensyn ...(...) det krever et eller annet for å få det til å fungere (...) jordbruket har jo blitt mye, mye flinkere til det.

Så er responsen frå ein reineigar vi snakka med:

Eg blir heilt gal av denne kartlegginga. Gal. 30\% prosent av arealet er meint å være nøkkelområder. Men kva med dei 70 resterande?! Du kan ikkje berre kaste bort $70 \%$ av beitearealet. (...) Dette handlar ikkje om å ta vare på reinbeiteområder.

Dette sitatet er representativt for det ei rekkje representantar frå reindrifta har sagt i andre intervju og uttrykt i den offentlege debatten. Frustrasjonen ser ut til å ligge i at dei oppfattar at bruksrettane dei har, blir sette under meir og meir press av eit aukande tal av interesser og interessentar som ønskjer å trekkje grenser, med meir eller mindre juridisk kraft, mellom reinbeiteområde og «sine» område og aktivitetar. Ein opplever at bruksrettane som går på tvers av grenser, mistar kraft i høve til rettane som er definert innanfor grensene.

Grunnen til at reineigarane reagerer på denne måten, er altså at ei slik kartlegging og ein slik tankegang bryt fullstendig med korleis utmarksbruken til reindrifta er praktisert - i eit intrikat samspel mellom menneske, dyr, klima, økologi og topografi. Reinens grenser er av natur variable og fleksible. Derfor blir det oppfatta som ei umogleg oppgåve å trekkje ei slik grense utan at ein fjernar seg frå måten reindrifta og dermed den samiske kulturen blir praktisert på (Fjellheim, 2012; Löf, 2014). 
Dette er døme på to grunnleggjande ulike syn på korleis ein ser utmarka og utmarksbruken. Planleggjarar søkjer å systematisere utmarka etter ein abstrakt kartesisk logikk, etter koordinatsystemets stamfar Rene Descartes, med så klare, konkrete og synlege grenser som mogleg. Reineigarar ønskjer å tilpasse seg reinsdyra sin respons på skiftande biologiske og fysiske forhold - og dermed halde seg til meir flytande grenser i eit skiftande terreng.

Moderne lov- og plansystem strevar altså med å handsame ein slik fleksibel utmarksbruk basert på dyrs åtferd. Men samstundes, korleis det same systemet likevel vel å handsame dette, påverkar i stor grad korleis vi både formelt og emosjonelt reagerer på dyrs åtferd.

De må finne seg i å bli med på slike prosesser. Ja, altså det må bli sammenlignbart i hvert fall, deres forvaltning med den øvrige forvaltningen. Sånn at det går an å snakke litt lettere i lag.

... seier ein representant for Fylkesmannen, som meiner det er uunngåeleg at reindrifta må tilpasse seg moderne planprosessar, ikkje minst for å betre dialogen. For dersom ikkje, så blir dei verande ei gruppe som «alltid seier nei» og dermed undergrev legitimiteten til beitebruken som dei sjølve er så avhengige av. Men reindrifta føler seg her altså nærast tvinga til å tilpasse seg spelereglar til eit spel som dei ikkje er med og spelar. Eit spel som ikkje stemmer overeins med korleis ein både brukar og oppfattar utmarka. Som Siri Veland mfl. (2014, s. 296) uttrykkjer det i ein forskingsartikkel om korleis urfolks verdsbilde ikkje nødvendigvis rimar med den forståinga av verda som ligg til grunn for notidas utvikling og bruken av digitale kartverktøy:

Although Western ontologies and spatial representations reflect Western understandings of human experience, they are often inappropriate in Indigenous contexts. In efforts to be represented in courts and land management, Indigenous groups nevertheless need to engage Western spatial representations to 'claim space'.

Grensene for utmarksbruken til den sør-samiske reindrifta er styrt av biologiske og fysiske forhold som menneske i liten grad rår over. Den grensa som reindrifta i praksis brukar for å administrere og forvalte næringa, er 
altså fundamentalt forskjellig frå den grensa som planmyndigheitene vil at dei alle skal halde seg til - og som dei meiner landbruksnæringa elles, likt andre aktørar i utmarka, har vorte «flinkare» til å halde seg til, som det vart sagt i eit av intervjua. Sjølv om dei juridiske beiterettane altså er basert på lang tids bruk der nettopp grensene har vore dynamiske og flytande.

\section{Rettar, rettferd og rett ferd i det sør-samiske landskapet}

Grenser blir trekte i beste meining, for å skape romlege skilje mellom mitt og ditt, og mellom rett og gale. I utmarka så vel som i andre landskap. Grenser, i lag med ei tekst som beskriv kva som er greitt og ikkje innanfor dei avgrensa områda, blir eit slikt verktøy bruka i eit forsøk på å skape ei slags romleg rettferd. Fleire geografar har hevda at meir merksemd retta mot det romlege aspektet av rettferd kan vise oss at rettferd er skapt i og gjennom geografien og landskapet, og at verken rettferd eller rett ferd er noko som er absolutt eller universelt (Brown et al., 2019; Harvey, 1996; Philippopoulos-Mihalopoulos, 2015; Soja, 2010).

Rettferd handlar om «kven får kva, når og korleis» (Smith, 1994), og det finst ulike typar av rettferd. Ein slik type er det som blant andre Waterstone (2010) omtalar som «procedural justice» - altså rettferd knytt til prosedyrane rundt fordeling. Dette handlar om at når rammene for prosessen er lagt av dei som er i posisjon til å gjere dette, så blir det tale om kva prosedyrar som skal gjeld når ein inviterer folk med i desse prosessane, og om korleis ulike grupper og individ får delta i avgjerande prosessar og dermed får ta val, løyse konfliktar og fordele ressursar. Dette handlar om kven som blir invitert inn i høyringsprosessar, kven som får uttale seg, og kven som blir høyrt. Det har for eksempel vorte peika på at sjølv om planprosessar i utmarka involverer reindrifta, så har representantane for reindrifta store problem med å følgje opp alle sakene på grunn av at få personar skal ta seg av mange saker over store areal (Rønningen \& Flemsæter, 2016). Dette er vel og bra, og det er relevant å diskutere korleis den sør-samiske reindrifta så vel som andre interessentar er inkludert når det gjeld korleis dei ulike aktørane blir tekne med i 
dei prosessane som blir gjennomført for å få til ei best mogleg forvaltning av utmarka. Det er for eksempel nettopp ei slik rettferd det er lagt opp til når reindrifta og andre interessentar på lik linje blir bedt om å trekkje grenser rundt det som dei ser på som dei viktigaste områda for sin utmarksbruk. Men dette perspektivet på rettferd kan fort oversjå sjølve samspelet og samskapinga av rett og urett som skjer mellom aktørane menneske og dyr - i landskapet.

For kva med sjølve føresetnadane for den rettferdige deltakinga? I eksempelet vårt er altså kartet og grensedragingar ein slik føresetnad. Og da kjem vi til ein annan type rettferd, nemleg "produktiv rettferd». Dette handlar om kven som skaper spelereglane, om kven som produserer det rammeverket som ulike partar må halde seg til (Waterstone, 2010; Young, 2011). Dei som skaper og produserer mekanismane, rammeverket og alternativa ein har å velje mellom, styrer òg dermed i stor grad kva for moglege utfall prosessane har, og dermed, i vårt fall, kven det er som set premissane for korleis utmarksforvaltninga, og deltakinga, skal gå føre seg. For i det heile å begynne å diskutere kva som er rett, rettferdig og rett ferd i utmarka, så må ein ha ein rettferdig "produksjon», og felles forståing, av dei grunnleggjande spelereglane. Ein må ha ei felles forståing og eit felles sett med omgrep, og det er her vi igjen kjem til grensene i det sør-samiske reindriftslandskapet. For når det gjeld grensedragingar i denne delen av utmarka vår, og kanskje mange andre deler av utmarka, så manglar ei slik felles grunnleggjande forståing. Medan dei grensene den sør-samiske reindrifta held seg, til er fleksible og flytande, og produsert og reprodusert gjennom denne vekselen mellom landskap og landskapsbruk, mellom dyr og folk, så tenkjer planforvaltninga at grensene som skal skilje ulik bruk frå kvarandre, og som skal definere rett og urett, kan einast om og teiknast opp på kontora og møteromma.

For å forstå implikasjonane av desse grunnleggjande ulike forståingane av kva ei grense er, så kan det å sjå på dette sakskomplekset gjennom Haraway (2008) og Brown og Dilley (2012) sitt response-ability-perspektiv hjelpe oss. Dersom utmarka sine spelereglar er bygd opp rundt den abstrakte og statiske grensa på kartet, så vil reindrifta kunne bli tvinga inn i eit spel der dei ikkje har fått vere med å forme spelereglane. Konsekvensen blir at dei ikkje har same høve som andre utmarksbrukarar til å 
respondere på og tilpasse seg endringar i utmarka. For at dei ulike aktørane skal ha ei nokolunde lik response-ability, altså likt høve til å gjere slike tilpassingar, må føresetnadane for deltaking vere basert på ein rettferdig produksjon av eit felles sett av spelereglar. På bakgrunn av dei ulike syna på utmarksgrensene, og vekta det samstundes blir lagt på desse grensene i forvaltninga, gjer at det er grunn til å stille spørsmål om ein slik rettferdig produksjon av spelereglar er til stades i dag. På vegen mot gode løysingar og rettferd i utmarksforvaltninga må vi auke merksemda på korleis eit intrikat samspel mellom menneske og dyr skaper grenser, åtferd og handlingsrom. Slik kan vi kan kanskje frigjere oss frå gamle opptrakka, konfliktfylte stiar, og heller nærme oss ei felles forståing, der alle har nokolunde likt høve til å respondere på og tilpasse seg endringar i utmarka, og dermed danne eit rettferdig grunnlag for deltakande prosessar.

\section{Å forvalte det ukjente}

I den norske utmarka ser vi altså at kommodifiseringsprosessar ikkje berre endrar korleis vi orienterer oss når det gjeld å verdsette utmarksressursane, men dei endrar òg etablerte praksisar som bind landskap, folk og dyr saman. Og sidan det er desse etablerte praksisane som har definert dei juridiske rettane som sør-samane har til å drive reindrift, så ser vi òg at kommodifiseringa utfordrar nettopp desse. Som den politiske filosofen MacPherson (1978) har hevda, så er det når behova folk ser i ein ressurs endrar seg, at retten til ressursen blir kontroversiell.

I utmarka i dei sør-samiske områda har både reindrifta, bønder og ei rekkje andre rettshavarar ein rett til ressursbruk, og dermed ein rett til ikkje å bli ekskludert. Reindriftas rettar har vore under press gjennom store delar av 18- og 1900-talet. Men som vi har sett i dette kapittelet, med den pågåande kommodifiseringa av utmarka så ser det ut til at reindrifta sitt høve til å utøve retten sin i praksis blir ytterlegare svekka. Innhaldet i rettane til dei ulike partane er og skal vere ulike, men høve til å utøve, forsvare og vedlikehalde rettane dei har, burde i utgangspunktet vere like. Men slik er det i minkande grad. Måten reindrifta har praktisert aktiviteten sin, og dermed definert rettane, har både vorte vanskelegare 
å gjennomføre og den har mista noko av den avgjerande legitimiteten. Dei juridiske rettane er intakte, men høve til å praktisere dei gjennom dyr-menneske-relasjonar har vorte redusert.

Noko av problemet knyter seg nok til at mykje av reindrifta sin utmarksbruk er usynleg - i den forstand at det kan gå lang tid mellom kvar gong reinsdyra faktisk beitar eller ferdast i dei enkelte areala. Men moglegheita og potensialet som ligg i desse beiteareala, kalvingsområda og trekkvegane, er likevel viktig for reindrifta. Vi treng altså å gjere oss betre i stand til å handtere og forvalte potensiell ferd, i staden for berre å halde oss til faktisk ferd, gjennom utmarkslandskapet med all kompleksiteten det fører med seg. Blomley (2013) skriv om eigedom som "possibilities of performance» - altså eigedom som noko som gjer handling mogleg. Kanskje bør vi og snu litt på dette og tenkje over korleis vi kan forvalte utmarka ut frå ei forståing av «performance of possibilities». Vi bør altså tenkje på korleis vi kan forvalte ein potensiell, usynleg og latent bruk som er vanskeleg å kartfeste - i alle fall om vi tenkjer at kartfesting er absolutt og konstant og ikkje kan vere flytande eller skiftande.

For å illustrere dette med reindrifta så kan det altså vere behov for å bruke areala annleis, kanskje neste år, kanskje om ti, kanskje om tjue år, avhengig av korleis reinen tilpassar arealbruken sin til skiftande beiteog kalvingsforhold. Men samstundes er nettopp bruken og utnyttinga av retten viktig for å vedlikehalde og oppretthalde rettane som ulike aktørar har (Blomley, 2013). Men kor gjentakande, kontinuerleg, føreseieleg og hyppig må ein bruk vere før ein mister legitimiteten til retten? Kva skjer med bruken, og dermed retten, etter at nye grenser for viktige område blir trekt og annan aktivitet etablerer seg i tilgrensande område? Korleis kan tid takast inn som eit element når grenser skal trekkjast i utmarka? Og korleis kan det stadig skiftande og flytande samspelet mellom dyr og menneske representerast i grensedragingane?

Nils Oskal (Bull et al., 2001; Bull, 2010) skriv at dersom ein skal følgje tradisjonen etter John Locke sine tankar om appropriering, så er eigedomsretten til land etablert gjennom arbeid definert som kroppsleg tilverknad. Ein slik tanke anerkjenner ikkje på same måte ein skiftande arealbruk skapt i samspel mellom dyr og menneske, som legg att få materielle spor. Vidare så ser vi frå måtane som reindrifta gjennom dette 
dyr-menneske-samspelet «materialiserer tida», at det her ikkje berre er snakk om romleg rettferd, men at dette ikkje gir fullstendig meining om vi ikkje òg talar om «temporær» rettferd.

Skal vi våge å ta desse temporære elementa av rettferd på alvor, må vi i tilfelle tole å leve med usikkerheit, vi må anerkjenne det usynlege og la terrenget heller enn kartet vere styrande for avgjerslene vi tek. I så fall vil vi måtte akseptere at vi ikkje alltid kan trekkje ei grense når vi føler vi har behov for det. Og at det her kanskje handlar meir om å avgrense oss enn om å trekkje nye grenser mellom oss.

Det er lærdom å hente her til andre delar av utmarka. I dette tilfellet såg vi at høve til å drive reindrift som eit samspel mellom dyr og menneske vart redusert av dei moderne spelereglane der ein avgrensar utmarka, for så å «ta den i bruk». Vi ser her ei vriding frå å sjå på rettane i utmarka ut frå eit funksjonelt og praktisk perspektiv som er kollektivt orientert, til i stadig større grad å sjå utmarka som eit areal som kan avgrensast og kontrollerast ut frå eit meir individuelt orientert og substansielt syn på eigedom, der eigarskapet til grunnen er i større grad enn før òg styrande for korleis alle ressursane på arealet blir bruka. Dette handlar i botn og grunn om kva for demokratiske modellar vi vil skal gjelde i utmarksforvaltninga. Vi treng å stille spørsmål om vi bør vidareutvikle desse modellane frå i første rekkje handle om rettferdig deltaking til i større grad å handle om rettferd når føresetnadane for deltakinga skal formast. Slik kan vi kanskje bli betre i stand til å handtere ei endra utmarksferd.

\section{Referansar}

Best, S. (1989). The commodification of reality and the reality of commodification: Jean Baudrillard and post-modernism. Current Perspectives in Social Theory, 19, 23-51.

Blomley, N. (2013). Performing property: Making the world. Canadian Journal of Law \& Jurisprudence, 26(1), 23-48.

Blomley, N. (2019). The territorialization of property in land. Territory, Politics and Governance, 7(2), 233-249.

Braverman, I. (2015). More-than-human legalities: Advocating an «animal turn» in law and society. I A. Sarat \& P. Ewick (Red.), The handbook of law and society (s. 307-321). 
Brown, K. M. (2015). The role of landscape in regulating (ir)responsible conduct: moral geographies of the 'proper control' of dogs. Landscape Research, 4o(1), $39-56$.

Brown, K. M. \& Dilley, R. (2012). Ways of knowing for 'response-ability' in morethan-human encounters: The role of anticipatory knowledges in outdoor access with dogs. Area, 44(1), 37-45.

Brown, K. M., Flemsæter, F. \& Rønningen, K. (2019). More-than-human geographies of property: Moving towards spatial justice with response-ability. Geoforum, 99, 54-62.

Bull, K. S. (2001). The right to herd reindeer in the light of the report of the Sami law committee. International Journal on Minority and Group Rights, 8(2), 223-234.

Bull, K. S. (2010). Reindriftas bruksrettigheter. Kart og Plan, 2010(3), 174-181.

Bull, K. S., Oskal, N. \& Sara, M. S. (2001). Reindrifta i Finnmark: Rettshistorie 1852-1960. Cappelen Akademisk Forlag.

Fjellheim, E. M. (2016). Vindmøller truer sørsamisk kultur. Radikal portal. https:// radikalportal.no/2016/o9/o7/vindmoller-truer-sorsamisk-kultur-1/

Fjellheim, S. (2012). Gåebrien sijte: en sameby i Rørostraktene. Røros.

Flemsæter, F., Setten, G. \& Brown, K. M. (2015). Morality, mobility and citizenship: Legitimising mobile subjectivities in a contested outdoors. Geoforum, 64, 342-350.

Flø, B. E. (2011). Sex, sprit og storokse - marknaden i møte med den østerdalske elgjaktetos. I M. S. Haugen \& E. P. Stræthe (Red.), Rurale brytningar. Tapir.

Friluftsloven. (1957). Lov om friluftslivet (friluftsloven). LOV-1957-06-28-16. https:// lovdata.no/dokument/NL/lov/1957-06-28-16

Haraway, D. (2008). When species meet. University of Minnesota Press.

Harvey, D. (1996). Justice, nature and the geography of difference. Blackwell.

Landbruksdirektoratet. (2020). Reindriftskart. https://www.landbruksdirektoratet. $\mathrm{no} / \mathrm{nb} /$ reindrift/reindriftas-arealbrukskart

Locke, J. (1978). Of property. I C. B. Macpherson (Red.), Property. Mainstream and critical positions (s. 15-28). University of Toronto Press.

Löf, A. (2014). Challenging adaptability. Analysing the governance in reindeer husbandry in Sweden. (Ph.d.). Umeå universitet.

Macpherson, C. B. (1978). The meaning of property. I C. B. Macpherson (Red.), Property. Mainstream and critical positions (s. 1-13). University of Toronto Press.

Mitchell, D. (2003). The right to the city. Social justice and the fight for public space. The Guilford Press.

NRK. (2014). Påstand om ubenyttede arealer provoserer sametingspresidenten. https:// www.nrk.no/sapmi/_-er-nord-norge-et-odeomrade_-1.12039078

Ojalammi, S. \& Blomley, N. (2015). Dancing with wolves: Making legal territory in a more-than-human world. Geoforum, 62, 51-6o. 
Peil, T. \& Jones, M. (Red.) (2005). Landscape, law and justice. Novus Forlag.

Philippopoulos-Mihalopoulos, A. (2015). Spatial justice: Body, lawscape, atmosphere. Routledge.

Ravna, Ø. (2005). Oppfatningen av samiske reinbeiterettigheter som «tålt bruk» i jordskiftesaker. Lov og Rett, 44(10), 602-619.

Ravna, Ø. (2019). Same- og reindriftsrett. Gyldendal.

Reindriftsloven. (2007). Lov om reindrift (reindriftsloven). LOV-2007-06-15-40. https://lovdata.no/dokument/NL/lov/2007-06-15-40

Risvoll, C. \& Hovelsrud, G. K. (2016). Pasture access and adaptive capacity in reindeer herding districts in Nordland, Northern Norway. The Polar Journal, 6(1), 87-111.

Robberstad, K. (1963). Kløyvd eigedomsrett. Lov og Rett, 162-166.

Rønningen, K. \& Flemsæter, F. (2016). Multifunctionality, rural diversification and the unsettlement of rural land use systems. I Routledge international handbook of rural studies (s. 312-322). Routledge.

Sager, T. (1994). Communicative planning theory. Ashgate.

Sager, T. (2018). Communicative planning. I M. Gunder, A. Mandanipour \& V. Watson (Red.), The Routledge handbook of planning theory, 93-104. Routledge.

Skjeggedal, T. (2020). Land use planning in disputed mountain areas: Conflicting interests and common arenas. Journal of Environmental Planning and Management. https://doi.org/10.1080/09640568.2020.1812379

Smith, D. M. (1994). Geography and social justice. Blackwell.

Soja, E. W. (2010). Seeking spatial justice. University of Minnesota Press.

Store norske leksikon. (2021). Grenser. Henta frå https://snl.no/grenser

St.meld. nr. 19 (1999-2000). Om norsk landbruk og matproduksjon. Landbruksog matdepartementet. http://www.regjeringen.no/nb/dep/lmd/dok/regpubl/ stmeld/1999200o/Stmeld-nr-19-1999-2000-.html

Veland, S., Lynch, A., Bischoff-Mattson, Z., Joachim, L. \& Johnston, N. (2014). All strings attached: Negotiating relationships of geographic information science. Geographical Research, 52(3).

Waterstone, M. (2010). Geography and social justice. I The Sage handbook of social geographies (s. 419-434). Sage.

Young, I. M. (2011). Responsibility for justice. Oxford University Press. 



\title{
Rovviltforvaltning og reindriftsnæringen: Hvordan kan en todelt målsetting praktiseres i samsvar med internasjonale konvensjoner?
}

Svein Morten Eilertsen

Norsk institutt for bioøkonomi (NIBIO)

Jan Åge Riseth

NORCE Norwegian Research Centre

\begin{abstract}
In Norway, both reindeer herders and sheep farmers base their meat production on natural outfield (utmark) pastures during the summer. In winter, most of the sheep are housed and fed indoors, while the reindeer survive on outfield pastures the whole year. During the last few decades, the losses of both sheep and reindeer to protected carnivores has increased in several areas in Norway. In this article, we focus on reindeer herding in the Troms and Nordland reindeer grazing area (reinbeiteområde). Due to large losses of reindeer calves, during the period from their birth in spring until late autumn, several reindeer herding districts hardly have any animals for slaughter. This has a very negative impact on both the economy and the cultural way of life. This article also discusses the reasons why it is difficult to document/prove who or what is responsible for the losses of reindeer calves. It is difficult to get permission to cull extra-active predators if the politically determined quota in each management region is not fulfilled. Documenting the correct number of predators inside each management region is therefore very important for reindeer herding and sheep farming. This has led to criticism and demonstrations by reindeer herders and sheep farmers. Norwegian predator policy formally builds on differentiated management. However, external review reveals that the management
\end{abstract}

Sitering: Eilertsen, S. M. \& Riseth, J. Å. (2021). Rovviltforvaltning og reindriftsnæringen: Hvordan kan en todelt målsetting praktiseres i samsvar med internasjonale konvensjoner? I F. Flemsæter \& B. E. Flø (Red.), Utmark $i$ endring (Kap. 8, s. 213-238). Cappelen Damm Akademisk. https://doi.org/10.23865/ noasp.151.ch8

Lisens: CC BY-NC-ND 4.0 
model builds on erroneous assumptions. Further, international law also requires that the burden created by predators does not unduly affect indigenous culture. The authors conclude that there is a need for extensive reforms in predator management in Norway.

Keywords: Bern convention, economic loss, International Covenant on Civil and Political Rights, knowledge (ways of knowing), management system, predators, reindeer herding, trust

\section{Introduksjon}

Siden 1980-tallet har det vært en økning i tap av lam til fredet rovvilt. For reindriftsnæringen ser man en tilsvarende økning i tapet av reinkalver fra begynnelsen av 2000-tallet i mange reinbeiteområder. Det er særlig i Troms, Nordland og Nord-Trøndelag at mange reinbeitedistrikter har registrert en nedgang i tilgangen på reinkalver om høsten (sett i forhold til antallet voksne simler i reinflokken). I dette kapittelet ser vi på konsekvensene dette kalvetapet har for reindriftsnæringen. Vi diskuterer også utfordringene næringen har med å klare å dokumentere hvem som er skadegjører. Dokumentasjon av antall rovvilt innenfor hvert enkelt forvaltningsområde for rovvilt er svært viktig for muligheten næringen har til å eventuelt få fellingstillatelse på aktive skadegjørere. Vi legger også fram resultatene av evalueringene av forvaltningssystemet som dokumenterer at forutsetningene for differensiert forvaltning ikke er til stede. Vi kopler analysen mot samfunnsendringer og arealinngrep og drøfter hvorfor beitenæringenes posisjon er mye mer utsatt enn for et par generasjoner siden. Vi påpeker at Norges iverksetting av Bernkonvensjonen synes å kollidere med det internasjonale urfolksvernet. Vi konkluderer med at rovdyrforvaltningen bør endres med reell delegasjon av både makt og ansvar til regionalt nivå. Det innebærer at alle beitebrukeres lokale og tradisjonelle kunnskap må anerkjennes og legges til grunn for framtidig rovdyrforvaltning.

Beregninger viser at norske husdyr i 1939 høstet rundt 700 millioner fôrenheter (f.e.) i utmarka. I dag er dette tallet redusert til 330 millioner årlig. Med en f.e.-pris på 4 kr er fortsatt verdien av denne utmarksbeitingen 1320 millioner kroner. I tillegg er det rundt 214 ooo reinsdyr (pr. 1. april 2020; Landbruksdirektoratet, 2020) som livnærer seg på 
utmarksbeiter 365 dager i året. Reindrifta har årlig produsert mellom 1388 og 1798 tonn kjøtt den siste tiårsperioden (Landbruksdirektoratet, 2020). Reindrift utøves primært i det samiske reinbeiteområdet som strekker seg fra Finnmark i nord til Hedmark i sør. Dette området er igjen inndelt i seks samiske regionale reinbeiteområder. Utenfor det samiske reinbeiteområdet utøves reindrift på særskilt grunnlag i Trollheimen og i Valdres. I Nord-Gudbrandsdalen utøver fire tamreinlag ikkesamisk reindrift. I 1998 fikk i tillegg Rendal renselskap, et foretak i NordØsterdalen, innvilget konsesjon til å utøve en særegen driftsform basert på jakt på privateide dyr (Landbruksdirektoratet, 2019). ${ }^{1}$

Deler av både saue- og reindriftsnæringen rapporterer om store årlige tap av dyr til fredet rovvilt. Dette tapet fører til redusert produksjonsresultat og økonomiske tap. For enkelte produsenter kan tapene være så store at de taper avlsmessig framgang ved at de ikke har tilstrekkelig antall lam/reinkalver av god kvalitet som kan erstatte utrangerte/ tapte produksjonsdyr. Enkelte produsenter har gitt opp produksjonen på grunn av den uholdbare situasjonen med årlige høye tap av dyr til fredet rovvilt. Høye tap av sau og reinsdyr til fredet rovvilt kan derfor føre til en redusert høsting av de tilgjengelige utmarksressursene. Dette vil føre til at deler av den biologisk viktige beitepåvirkede utmarka gror igjen og går tapt.

Et eksempel på en kommune der dette for lengst er realiteten, er Lierne kommune langt nord i Trøndelag:

Eit tydeleg eksempel er Lierne kommune som i 1995 hadde 45 aktive sauebønder, redusert til 28 i 2001 og til 5-6 i 2012 [...] Det er ingen tvil om at det er tap av sau på grunn av bjørn som er den viktigaste årsaken til denne nedgangen [...] konsekvensen av politikken er ei særs skeiv fordeling, ved at det er distrikta, og særleg fjellkommunane som må bere tapet av reinsdyr og sauar. (Teigen \& Skjeggedal, 2015, s. 49-50)

1 Se også kapittel 2, som analyserer reindriftas sårbarhet ved å fokusere de samlede effektene av inngrep og forstyrrelser. Tap forårsaket av rovdyr er en av faktorene som bidrar til å svekke reindriftas tilpasningspotensiale og forsterker effektene av arealinngrep. Kapittel 2 dokumenterer dette ved konkrete eksempler fra to reinbeitedistrikter i Nordland og Troms. 
Bakgrunnen for dagens utfordringer med rovdyrpolitikken ligger flere tiår tilbake. Mens de store rovdyrene gaupe, jerv, ulv og bjørn tidligere ble holdt i sjakk ved hjelp av skuddpremier, skjedde det fra og med 1960/70-tallet et politisk skifte som førte til at rovdyrene etter hvert ble fredet. Både kongeørn og havørn har vært fredet i Norge siden 1968. Ulven ble fredet i 1971, bjørnen i 1973, jerven i 1973 i Sør-Norge og i 1982 i Nord-Norge og sist gaupa i 1992 (Naturvernforbundet, 2019; Ree, 2008; Rovdata, 2020). Den europeiske Bernkonvensjonen, egentlig Konvensjon vedrørende vern av ville europeiske planter og dyr og deres naturlige leveområder, var medvirkende til at Norge i 1981 fikk en viltlov der alle høyerestående dyr i prinsippet er fredet, dvs. all jakt må være tillatt spesielt (Bernkonvensjonen, 1979). Denne politiske snuoperasjonen har over de etterfølgende tiårene ført til store økninger i rovdyrstammene.

I dag bygger norsk rovdyrpolitikk på en dobbel målsetting om å ivareta både levedyktige rovdyrstammer og beitedyr i utmark konkretisert i det såkalte rovdyrforliket basert på bestandsmål, kvotejakt, lisensfelling og skadefelling (Klima- og miljødepartementet, 2020). Grunnprinsippene i norsk rovdyrpolitikk ble lagt i stortingsmeldingen Rovvilt $i$ norsk natur, godkjent i statsråd 12.12.2003 (St. meld. nr. 15 (2003-2004)). Dette er senere fornyet i Stortinget flere ganger, se tekstboks 1.

Mye av både rovdyrforskningen og den offentlige debatten om rovviltforvaltningen dreier seg om ulv og har søkelys på situasjonen på Østlandet (Skogen et al., 2010).

\section{Tekstboks 1}

INNSTILLING 251 (2016-2017) Komiteen viser til Innst. 174 S (20032004), Stortingets behandling av Meld. St. 15 (2003-2004) Rovvilt i norsk natur, der det fremgår at «Komiteen vil understreke at den todelte målsettingen skal opprettholdes og mener at det fortsatt skal være mulig med levedyktig næringsvirksomhet i området med rovvilt».

Komiteen peker på at Stortinget etter dette flere ganger har påpekt den todelte målsetningen, og at det aldri har vært noe politisk vedtak som har endret dette. Komiteen legger til grunn at denne forståelsen fortsatt gjelder. 
For oss som er opptatt av reindriftas vilkår framstår mye av den typiske sørnorske rovdyrdebatten som noe perifer, bl.a. med et kanskje uforholdsmessig sterkt fokus på en relativt marginal art, ulven. I reindrifta er det rovdyr som jerv og gaupe, men også bjørn og ørneartene som har størst betydning. I dette kapittelet tar vi sikte på å bidra til å øke innsikten i reindrifta sine rovdyrproblemer. Selv om de er store og til dels godt dokumenterte, er de lite kjent for allmennheten. Dette skyldes nok både at den generelle kunnskapen om reindrift er begrenset utenom de mer eller mindre innvidde, og at en del sammenhenger er komplekse.

Reindrifta har til alle tider stått $\mathrm{i}$ et konkurranseforhold til rovdyra. Historisk har rovdyra vært en del av reindriftas rammebetingelser. Mens rovdyra har beskattet rein, har reindriftssamene beskattet rovdyra. Ettersom jakt på rovdyr har vært ressurskrevende, har det tradisjonelt vært rasjonelt for reineierne å ta ut de verste skadegjørerne. Nært samkvem og betydelig respekt for rovdyra har gitt reindriftsbefolkningen en unik kunnskap om disse dyra (Sikku \& Torp, 2008). Bjørnen hadde f.eks. en spesiell status i den gamle samiske religionen og var ansett både som et hellig dyr og et mytologisk vesen (Svendsen, 2019). Ritualene for bjørnejakt ble vist fram i den samiske filmsuksessen «Veiviseren» (Svendsen, 2020). Reindriftssamenes kunnskapsbase benyttes ikke i dagens rovdyrforvaltning (Eira \& Sara, 2017; Sletten, 1997b).

Reindrifta tok de største stegene inn i den moderne verden med utstrakt bruk av motorkjøretøyer, pengehusholdning og inkorporering i statlig næringspolitikk på 1960-70-tallet mens det enda var et relativt rovdyrfritt miljø. Situasjonen etter årtusenskiftet er en ganske annen, særlig i Nord-Trøndelag, Nordland og Troms, hvor rovdyrtrykket er blitt et av reindriftas hovedproblemer (Danell, 2010; Haugerud, 2010; Riseth, 2014).

\section{Reindriftsnæringen, produksjon og tap av rein til fredet rovvilt}

Landbruksdirektoratet publiserer hvert år rapportene Ressursregnskapet for reindriftsnoeringen og Totalregnskapet for reindriftsnoeringen. I disse finner man sentrale drifts- og regnskapstall for tamreindrifta i Norge. De ulike opplysningene er differensiert på reinbeiteområde, og for mange 
også på distriktsnivå. Gjennomgang av disse tallene kan vise utvikling $\mathrm{i}$ driftsforholdene for reindrifta over tid.

I reindrifta bruker man uttrykket «kalvetilgang». Dette er andelen (prosent) kalver i reinflokken i forhold til antall simler i vårflokk. Kalvetilgangen om seinhøst / tidlig vinter («kalvetilgang etter tap») er den andelen reinkalv som reineieren har igjen som enten går til slakt eller til påsett for å erstatte tapte voksne dyr samt dyr som skal utrangeres på grunn av alder, dårlig kondisjon eller som del av driftsopplegget. Med en større kalvetilgang vil reineieren ha mange kalver som kan sendes til slakt i tillegg til at man har mange kalver å velge imellom når man skal plukke ut kalver til nyrekruttering i flokken. Dersom kalvetilgangen er dårlig, blir situasjonen helt motsatt. Reineier kan bli nødt til å bruke middels til dårlige kalver til nyrekruttering. I tillegg resulterer få kalver til slakt i dårlig økonomi for reineieren.

Når det nærmer seg tid for kalving trekker reinsimlene mot områder de tradisjonelt bruker som kalvingsområder. De fleste simlene velger det samme kalvingsområdet hvert år. Simlene pleier å trekke seg bort fra de andre når de skal kalve, og holder seg for seg selv sammen med den nyfødte kalven like etter fødselen. Dette er viktig for at det skal danne seg sterke bånd mellom kalven og simla slik at kalven følger mora tett gjennom sommeren og fram mot vinteren. I mange reinbeitedistrikter er det tradisjon for å la simleflokken få være mest mulig uforstyrret under kalvingen. Tilsyn gjennomføres på avstand (med kikkert fra utsiktspunkter) og gjennom «kantgjeting» der man beveger seg rundt simleflokken, hele tiden på god avstand. På grunn av denne driftstilpasningen, der man ikke ønsker å forstyrre simlene, har ikke reineiere fullstendig oversikt over hvor mange simler som får kalv (kalvingsprosenten). I en simleflokk som har vært i tilfredsstillende kondisjon gjennom vinteren regner man med at over 90 prosent av simlene er drektige og får kalv. Dette støttes av Karlsson et al. (2012), som viste at 91-95 prosent av simlene (totalt 1695 undersøkte dyr) var drektige under drektighetsundesøkelse i mars i årene 2010-2012. Det er først under kalvemerking fra slutten av juni og utover at reineierne får samlet oversikt over kalvetilgangen i flokken. Reindriftsnæringen har dermed en utfordring i å dokumentere nøyaktig hvor mange reinkalver som er født, sammenlignet med f.eks. sauenæringen 
der hvert enkelt nyfødt lam får tildelt øreklips med individuelt nummer og eierforhold registrert i klipset.

En følge av dette er at reindrifta også har utfordringer med å dokumentere det «tidlige kalvetapet», dvs. det tapet som skjer mellom fødsel og kalvemerking. En svensk studie av bjørnepredasjon på rein viser imidlertid at det langt på veg er mulig å dokumentere bjørnepredasjon både i tid og rom. Studien var planlagt i nært samarbeid mellom reineierne i to samebyer og forskerne, og baserte seg på bruk av samarbeidende GPS-sendere på drektige simler og bjørner (Karlsson et al., 2012). Studien er dessuten et godt eksempel på at samskaping av kunnskap der man bygger ned skillet mellom lokal og tradisjonell kunnskap og forskerkunnskap har framtida for seg (Agrawal, 1995).

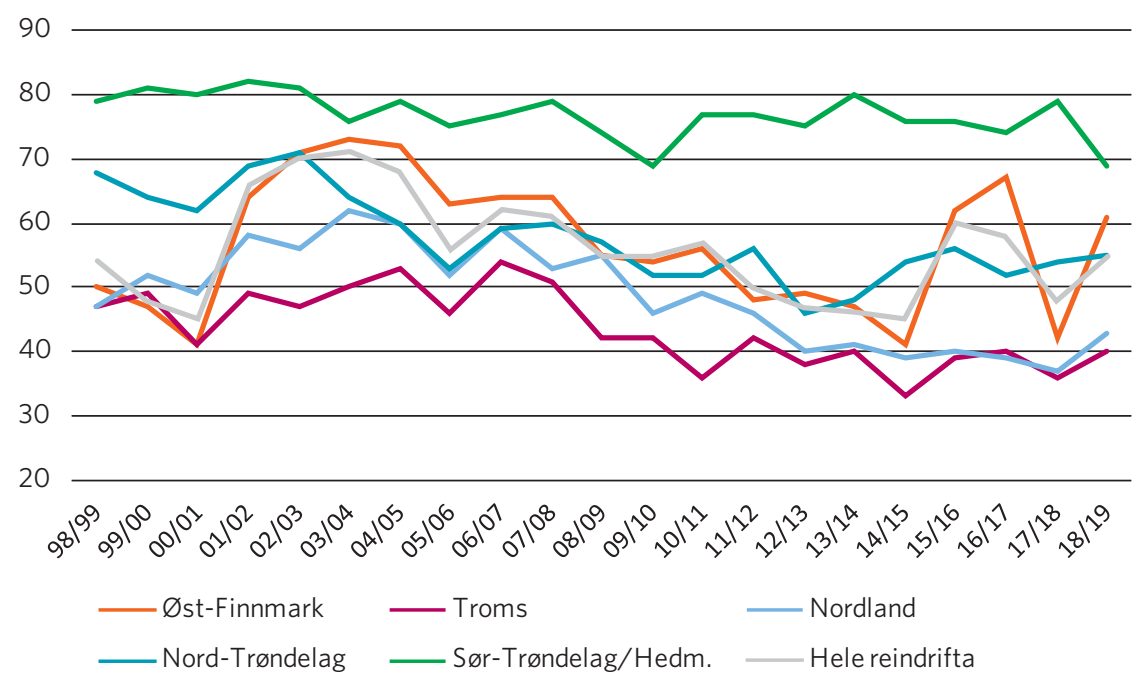

Figur 1. Kalvetilgang «etter tap» for utvalgte reinbeiteområder i Norge samt hele reindrifta for perioden 1999-2019 (Kilde: Landbruksdirektoratet, 2020).

Det har vært en jevnt fallende kalvetilgang (etter tap) for de fleste reinbeiteområdene i Norge de siste 20 årene (figur 1). Særlig for reinbeiteområdene i Nordland og Troms har kalvetilgangen vær svært lav siden ca. 2010. Kalvetilgangen har ikke vært over 50 prosent i hele denne perioden, og i enkeltår har tilgangen vært under 40 prosent. Dersom man sammenligner med reinbeitedistriktene i Sør-Trøndelag og Hedmark (figur 1), ser man at kalvetilgangen i dette reinbeiteområdet har variert mellom 70 og 
8o prosent. Når man ser på det enkelte reinbeitedistriktet, er det distrikter i både Troms og Nordland som i enkeltår har kalvetilgang helt ned mot (og under) 20 prosent.

Ifølge ressursregnskapet for reindriftsnæringen ser vi at gjennomsnittlig årlig tap av voksne rein har variert rundt 13-15 prosent både i Troms og Nordland de siste årene. Disse voksne dyrene må erstattes av reinkalver for å opprettholde størrelsen på reinflokken. Når vi vet at kalvetilgangen har vært svært lav i disse områdene, blir det svært få kalver igjen som kan sendes til slakt. Dette vises igjen i statistikken over produktiviteten (slakteuttaket i forhold til vårflokk). Det siste tiåret har den gjennomsnittlige årlige produktiviteten (slakteuttaket) i både Troms 3,9 kg/rein $(2,5-5,6)$ og Nordland 4,7 kg/rein $(3,3-5,3)$ vært svært lavt sammenlignet med Sør-Trøndelag og Hedmark 12,2 kg/rein (8,6-14,5). Det opereres med en «norm» for bærekraftig reindrift (Landbruksdirektoratet, 2019) som tilsier en årlig produksjon på $8 \mathrm{~kg} /$ livdyr. Vi ser at reindrifta i både Troms og Nordland ikke er i nærheten av å nå denne normen.

Dagens situasjon for reindriftas tap av rein til fredet rovvilt er en helt annen enn i midten av forrige århundre. Skjenneberg og Slagsvold (1968, s. 167) sier bl.a.: «Både i Skandinavia og Sovjetunionen har det vist seg at rovdyrene ikke er blant de viktigste årsaker til tap av dyr i tamreindriften». De viste til Nord-Trøndelag, der det årlige totaltapet av rein per år for perioden 1948-1956 i gjennomsnitt var 6 prosent av flokken. Av dette tapet vurderte de rovviltets andel til å være rundt 25 prosent. Dette betyr at de anslo det årlige tapet av rein til rovvilt var 1,5 prosent av reinflokken.

Generelt sies at størrelsen på reinen og slaktevektene begrenses av mattilgangen på sommeren. Produktiviteten og antall dyr som overlever begrenses av mattilgangen på vinteren (Klein, 1968). På grunn av at de fleste vinterbeiteområdene i Troms, Nordland og Nord-Trøndelag er kystnære og påvirkes av kystklimaet, opplever en ofte at beitene «låses» av islag eller svært våt og tung snø. Med de pågående klimaendringene kan en forvente at disse utfordringene er økende for reindrifta. Det er derfor ikke uventet at man forsøker å forklare den lave produktiviteten (kilo kjøtt/livdyr) i bl.a. Troms og Nordland med vanskelige beiteforhold forårsaket av vinterklimaet. På grunn av stadig hyppigere perioder med vanskelige beiteforhold, praktiserer mange reinbeitedistrikter i dette 
området derfor krise-/tilleggsfôring av reinen gjennom periodene med vanskelige beiteforhold.

Mange reinbeitedistrikter gjennomfører kalvemerking i perioden fra midtsommer og utover. I forbindelse med denne merkingen registreres kalvetilgangen i reinflokken. Etter kalvemerkingen er reinkalvene store og livskraftige og de følger reinsimla med letthet. Det er forventet at en svært liten andel av disse kalvene skal dø som følge av sykdom eller ulykker i perioden fra kalvemerking og fram til høst/vintersamling. En gjennomgang av produksjonsdataene i Ressursregnskapet for reindriftsnoeringen viser at det har vært en betydelig økning i det sene kalvetapet for den siste tiårsperioden (2010-2019) sammenlignet med perioden før (2000-2009). Særlig for Troms, med økning på 10,6 prosent-poeng (fra 15,0 til 25,6), Nordland 15,3 prosent-poeng (fra 15,9 til 31,2) og NordTrøndelag 8,0 prosent-poeng (fra 15,9 til 23,9) har det vært en stor, statistisk sikker, økning. For reindriftsnæringen samlet har økningen vært på 4,7 prosent-poeng (fra 13,8 til 18,5). Denne klare økningen i det sene kalvetapet skyldes med stor sannsynlighet økt tap til fredet rovvilt.

Reindriftsnæringen ønsker å leve av å produsere reinkjøtt basert på utmarksbeiter og ikke statlige erstatninger for rovvilttatt rein. Gjennomgang viser at andelen utbetaling av erstatninger i forhold til produksjonsverdien av reinkjøttet (med biprodukter) for perioden 2000-2008 var 27,6 prosent. I perioden 2010-2018 var erstatningene økt til 57,9 prosent av kjøttverdi. Denne utviklingen, der erstatninger utgjør en stadig større del av «inntektene», er ikke ønsket av næringen.

Som en reindriftsutøver uttrykte seg: «Når man ikke har tilstrekkelig antall gode kalver å velge mellom når man skal rekruttere til reinflokken, hjelper det ikke med all verdens erstatninger. På lang sikt blir reinflokken gradvis svakere». Eller som professor Öje Danell spissformulerte det i et foredrag i 2012: «Reindrifta i Jämtland og Trøndelag er nær en kollaps på grunn av alle rovdyrene» (Hætta, 2012). Dette utsagnet er senere dokumentert ved sammenliknende forskning på to reinflokker i Östersundområdet. De to flokkene deler et felles barmarksbeite fra vår til sein høst, men beitet i hvert sitt område om vinteren. Fem års forskning dokumenterte at mens den ene flokken (A) hadde et gjennomsnittlig årlig tap av voksne simler på 7,1 prosent, var tapet helt oppe i 18,4 prosent for den 
andre flokken (B). Selv om slakteuttaket var begrenset, gikk reintallet i flokk B jevnt nedover fra år til år. Dette bekreftet at simletapet var så stort at denne flokken faktisk var i ferd med å kollapse. Beitebelegget var ikke stort, og det var ingen merkbar forskjell på simlenes fysiske kondisjon i de to flokkene. Det var heller ingen tegn på ulykker eller sykdom. Eneste mulige forklaring var predasjon, primært av jerv og gaupe (Åhman et al., 2014).

Situasjonen for et av de hardest rammede distriktene, Duokta i Nordland, er anskueliggjort i en podkast med distriktsleder Mats Pavall: «Spiralen på antall dyr går nedover hele tiden. Det er en alvorlig situasjon. Man klarer ikke å leve med reindrifta når man har så store tap» (Lian, 2020). Bakgrunnen er ifølge Pavall at de mister 30 til 40 prosent av reinen til rovdyr. Mens oversikten fra Miljødirektoratet angir at distriktet mener å ha mistet 305 rein til rovdyr i løpet av reindriftsåret 2018/2019 fikk de økonomisk erstatning for kun 129 dyr. Resten manglet de god nok dokumentasjon på (Verstad, 2020).

Rovdyrpolitikken har lenge vært omstridt, og både bønder og reindriftssamer har prøvd å mobilisere motstand. Et eksempel er at like oppunder jul 2010 mobiliserte mellom 1500 og 2000 bønder og reineiere felles sak og leide busser for å demonstrere mot rovdyrpolitikken foran Stortinget (Auestad \& Nilsen, 2010). Foranledningen var at Stortinget på nyåret skulle vedta nye bestandsmål for rovdyr. Demonstrantene nådde i liten grad fram.

\section{Rovviltforvaltning}

Rovviltforvaltningen følger bestandsmålene vedtatt av Stortinget. Ifølge rovviltforvaltningen har det ikke vært en økning i bestandene av store rovvilt gjennom denne perioden der reindriftsnæringen har registrert $ø$ kende tap av kalv. Hva kan da skyldes dette misforholdet mellom størrelsen på rovviltbestandene og kalvetapet? Reindriftsutøvere har flere mulige forklaringer på dette. Med de pågående klimaendringene blir perioden med sporsnø i lavlandet og i fjord- og kystnære strøk stadig kortere. Dette er ofte hjemmeområde for gaupe. For å oppfylle kravene til dokumentasjon av familiegrupper av gaupe må man ha mulighet til å 
finne og følge gaupespor over en viss avstand og innen en gitt dato hvert år (28. februar). Dermed bidrar klimaendringene til å vanskeliggjøre dokumentasjonen av gaupebestanden.

Dette ble tydelig illustrert under det årlige reindriftsseminaret som fylkesmannen i Nordland arrangerte i samarbeid med Nordland reindriftssamer (NRL) i Mosjøen 11. mars 2020. Da var størrelsene på rovviltbestandene i Nordland fylke et diskusjonstema. Jonas Kindberg, leder for Rovdata (www.rovdata.no), presenterte kart som viste at kun tre kjente familiegrupper av gaupe holdt til vest for E6. Samtidig ble det informert om at bestandsmålet om ti familiegrupper av gaupe innenfor rovviltsone 7 (Nordland) ikke var oppnådd de siste årene. Konsekvensen av dette er at det ikke åpnes for lisensjakt på gaupe. Flere av reindriftsutøverne på konferansen stilte spørsmål ved ressursinnsatsen som ble satt inn for å dokumentere gaupebestanden. Bl.a. ble det pekt på at Norges Jeger- og Fiskeforbund (NJFF), som har sporing av gaupe som spesialoppdrag, har et krav om å gjennomføre minst $498 \mathrm{~km}$ sporingsinnsats årlig - noe som ikke en gang tilsvarer lengden på Nordland fylke. Det ble også pekt på at en stor del av tilsynsarbeidet som personellet til SNO gjennomfører foregår på østsiden av E6. Når man i tillegg vet at det ikke foregår mye friluftsaktivitet (skigåing) i skogområdene i lavlandet eller i fjord- og kystnære strøk i vinterperioden, forblir kunnskapen om gaupebestandene i disse områdene svært mangelfull.

Norsk institutt for naturforskning (NINA) har gjennomført undersøkelser med radiomerkede gauper (Mattisson et al., 2015) som viste at voksne gauper tok mellom 3,6 og 10 reinsdyr per måned. Dersom det oppholder seg en eller flere «udokumenterte» gauper innenfor et reinbeitedistrikt sitt område og disse gaupene viser høy drapstakt på reinsdyr, vil tapene av rein kunne bli betydelig høyere enn forventet.

Reindriftsnæringen uttrykker at kongeørn kan gjøre betydelige innhogg i reinflokken. Særlig mener de at et betydelig antall reinkalver blir tatt av kongeørn. Reinkalver som blir tatt av rovvilt forsvinner svært fort, og sannsynligheten for at reineier skal finne disse og klare å dokumentere skadegjører er svært liten. Tidligere studier viser at tap av rein til kongeørn primært skjer i år med spesielt vanskelige beiteforhold (Tveraa et al., 2012). Studiene viser også og at kongeørna hovedsakelig tar små kalver 
(Nieminen et al., 2011; Norberg et al., 2006). Radiomerking av rein på Fosen i 2014 og 2015 har imidlertid dokumentert at også voksne simler ble tatt av kongeørn. Disse tapene skjedde primært gjennom sommeren og tidlig om høsten når mattilgangen for rein generelt er ansett som god (Odden et al., 2018). Disse nye arbeidene gir støtte til reindriftsnæringen, som gjennom lang tid har hevdet at kongeørna er en betydelig skadegjører i reinflokken.

Når reindriftsnæringen søker om erstatning for rein tatt av fredet rovvilt, foretas det skjønnsmessige vurderinger hos viltforvaltere på regionalt nivå. En viktig del av denne vurderingen er kunnskap om størrelsen på rovviltbestandene og forventet drapstakt hos rovviltet. For hele reindriftsnæringen har under 30 prosent av den tapte reinen blitt erstattet de siste årene. Det er regionale forskjeller, og for Nordland har rundt 45 prosent blitt erstattet i perioden 2011-2019. Som tidligere nevnt, er det særlig problemene med å finne tapte reinkalver og klare å dokumentere skadegjører for disse. Dette bidrar til at så lav andel av omsøkt tapt rein blir erstattet. Det er flere i reindriftsnæringen som uttrykker frustrasjon rundt denne skjønnsmessige vurderingen av hvor stor andel av de omsøkt tapte reinsdyrene som skal erstattes. Et eksempel er reineier og fylkesleder i Norske Reindriftsamers Landsforbund (NRL) i Nordland, Ragnhild Sparrok Larsen, som mener at «de store tapstallene er i ferd med å ta vekk framtidstroen på næringa - spesielt blant de unge» og advarer om at «hele den samiske kulturen står på spill» (Risholm, 2017). Et tydelig eksempel på frustrasjonen og avmakten som reindriftsnæringen føler vises i den felles uttalelsen som samtlige 12 reinbeitedistrikter i Nordland sto bak. Uttalelsen kom den etter den årlige dialogsamlingen mellom Fylkesmannen i Nordland og ledere av reinbeitedistrikter i Nordland (samling på Storjord i Saltdal 13. oktober. 2020). Rovviltsituasjonen var hovedtema på samlingen. I uttalelsen etter samlingen sies bl.a.:

Reindrifta er i en dyp krise, og vi kommer ikke i posisjon til å begynne å finne løsninger. Reindriftas rammevilkår forvaltes av mange sektorer/forvaltningsorganer i statsforvaltningen. Den oppstykkede forvaltningen utgjør for oss problemer som er uløst, og som har vært uløst i mange år. Utfra signalene på møtet 
på Storjord så innser vi at det ikke er hjelp å få fra reindriftas forvaltningsorgan.

[...] Vi ser derfor ingen hensikt å fortsette dialogen med Fylkesmannen om reindriftas rammevilkår. Vi har ikke tid til å definere Fylkesmannen rolle, vi må jobbe med utenforstående aktører slik at det faktisk finnes en reindrift å forvalte i fremtiden. Vår skjebne synes å være overlatt til oss selv. (Statsforvalteren i Nordland, 2020)

Tabell 1. Prioriterte rovviltområder i Nordland og hvor stor andel av disse som overlapper med reinbeiteområder fordelt på sesongbeiter (hentet fra Strand, 2016)

\begin{tabular}{lcccccc}
\hline Sesong & Totalt daa & Jerv \% & Gaupe \% & Bjørn \% & \multicolumn{2}{c}{ Rovdyrsoner samlet } \\
\cline { 6 - 7 } & & & & & Dekar & $\%$ \\
\hline Vinter & 14329626 & 33 & 34 & 12 & 4872061 & 34 \\
Vår & 10910836 & 28 & 30 & 2 & 2231201 & 30 \\
Sommer & 14426751 & 45 & 43 & 11 & 6643988 & 46 \\
Høst & 13339259 & 42 & 40 & 9 & 5621001 & 42 \\
Høst/vinter & 12364911 & 39 & 37 & 12 & 5050991 & 41 \\
Totalt beite & 32843412 & & & & 13315891 & 41 \\
\hline
\end{tabular}

For å oppnå bestandsmålet av fredet rovvilt, er det opprettet soner som er prioriterte for rovvilt. Innenfor disse sonene er det vanskelig å få tillatelse til lisensjakt eller skadefellingstillatelse på enkeltindivider. Disse sonene er forsøkt lagt utenfor kalvingsområdene til reindrifta. I tabell 1 (Strand, 2016) ser vi hvor stor andel av de prioriterte rovviltområdene i Nordland som overlapper med de ulike sesongbeitene til reindrifta. Eksempelvis overlapper de prioriterte jerveområdene med 33 prosent av vinterbeitene i Nordland. Nyere forskning (Mattison et al., 2015) utført av NINA viser at radiomerkede gauper og jerv hadde svært store revirer. Hanngauper hadde i gjennomsnitt $2605 \mathrm{~km}^{2}$ store hjemmeområder, mens hunngaupenes revirer var noe mindre $\left(1456 \mathrm{~km}^{2}\right)$ i gjennomsnitt. Tilsvarende hadde hannjerv svært store revirer $\left(1150 \mathrm{~km}^{2}\right)$, mens hunnjervens revir var noe mindre $\left(480 \mathrm{~km}^{2}\right)$. Med så store revirer vil ikke sonene som er prioriterte for rovvilt (i f.eks. Nordland og Troms) være tilstrekkelig store. Dermed er det uunngåelig at rovviltet i perioder vil bevege seg utenfor disse sonene og inn i områder som er prioritert for beitedyr (sau og rein). Dermed kan man oppleve at individer av jerv og gaupe, som betegnes som viktige for opprettholdelse av bestanden, oppholder seg i viktige beiteområder og 
kan gjøre betydelige skade. Beitenæringen kan oppleve at det er vanskelig å få skadefellingstillatelse på slike viktige individer. De vil dermed kunne sitte med en følelse av at rovviltforvaltninga svikter. Man kan, med rette, hevde at deler av Nord-Norge er for smalt til en forvaltning basert på at det skal være plass til både prioriterte rovvilt og beitedyrområder.

Rovdyrforskere i NINA fikk i oppdrag fra Miljødirektoratet å evaluere regional rovviltforvaltning og de regionale bestandsmålene i Norge med hensyn på måloppnåelse i gjeldene rovviltpolitikk (Krange et al., 2016). Evalueringen av rovviltforvaltningen tar utgangspunkt i rammene rundt den todelte målsettingen om at vi skal ha rovvilt og beitedyr i Norge. Vi har sakset noen hovedpoenger fra denne evalueringen:

De fleste av disse utfordringene [for den regionale rovviltforvaltningen] er knyttet til rammebetingelsene, og i mindre grad til hvem som tar avgjørelsene. Det er et misforhold mellom kravene om en svært presis forvaltning og de naturlige forutsetningene. Det vil alltid være usikkerheter knyttet til forvaltning av små rovdyrbestander. (Krange et al., 2016, s. 3)

Forskerne påpeker også en rekke sviktende forutsetninger for forvaltningsmodellen:

1. Systemet fungerer best med en buffersone mellom de to områdene, der rovdyr ikke får etablere seg, og hvor man initierer enklere forebyggende tiltak eller har beredskapsplaner klar hvis konflikter oppstår [...] Videre er det en forutsetning at rovdyrene effektivt blir ekskludert fra de prioriterte beiteområdene $[\ldots]$

2. Småskala geografisk differensiering for gaupe og jerv fungerer ikke. Det er urealistiske forventinger om at små beiteprioriterte områder, ofte omringet av rovviltprioriterte områder, skal være fritt for rovvilt. Konfliktene må forvaltes over større og mer sammenhengende områder. (Krange et al., 2016)

Vi mener at begge disse problemstillingene underbygger at det i realiteten ikke er mulig med en forvaltning basert på den todelte målsettingen i deler av Nord-Norge der sonene er for små sammenlignet med rovviltets hjemmeområder. Dette støttes av sluttrapporten fra Scandlynx-prosjektet for Troms og Finnmark, som slår følgende fast om gaupe og jerv i reinbeiteland: 
Reinsdyr var den viktigste matkilden for både jerv og gaupe. ${ }^{2}$ [...] Våre resultater viser at dagens forvaltningssoner i nord bryter med de grunnleggende forutsetningene for at sonering skal fungere tapsreduserende, ved at rovdyrsonene ikke er store nok til at rovdyrene kan oppholde seg innenfor sonen året gjennom. (Mattisson et al., 2015, s. 4)

Dagens rovdyrforvaltning har som mål å sikre overlevelse for alle de store rovviltartene i norsk natur og bidra til å dempe konfliktene og motvirke utrygghet innenfor den todelte målsettingen om bestandsmål for rovvilt og levedyktig næringsvirksomhet i landbruk og reindrift. Det er dette man omtaler som en differensiert forvaltning. Forvaltningen av rovvilt har i lang tid vært preget av høyt konfliktnivå mellom ulike berørte parter og forvaltningsorganene. For å dempe konfliktnivået og tilpasse forvaltningen etter lokale forhold har ulike varianter av økt medvirkning blitt prøvd ut. Siden 2005 har man hatt regionale rovviltnemder. Man har opprettet ulike soner for ulike rovviltarter og satt nasjonale og regionale bestandsmål for de ulike artene (Krange et al., 2016, sitert i Riseth \& Johansen, 2019).

Sosialøkologiske systemer kan ha en kompleks iboende dynamikk som kan lede til vanskelige dilemmaer. En casestudie gjennomført i Saltenområdet demonstrerer at den økologiske dynamikken mellom store rovdyr, sauer og rein skaper en gjensidig avhengighet i det sosial-økologiske systemet som man må ta hensyn til når man etterstreber slike dels motstridende mål. Et viktig funn i denne studien er at forvaltningssystemet ikke går direkte inn på slike avveininger.

Rovdyrforliket forutsetter i stedet at man kan forfølge et todelt mål. I stedet for å løse et kollektivt dilemma, fører slike mekanismer til sosiale og økologiske prosesser som gjør lokalsamfunn og pastoral sektor sårbare. Dagens styringsregime fremmer verken kulturelt eller biologisk mangfold. Når man søker etter innovative synergier, må kompromisser gjøres eksplisitte og tydelige for beslutningstakerne. (Risvoll et al., 2016, vår overs.)

2 I årstidene med rein tilgjengelig drepte gaupa mellom 3,6 og 10 reinsdyr pr. måned. Jerven drepte færre reinsdyr enn gaupa, med drapsrater som varierte mellom o,8 og 5 reinsdyr pr. måned. 
En annen studie sammenlikner den regionale rovviltforvaltningen i Jämtland/Sverige og Nordland/Norge. Sjölander-Lindqvist et al. (2020) analyserer hvordan internasjonale normer har blitt inkorporert i hvert av landenes rovdyrpolitikker, og hvordan dette la rammer for desentralisering og beslutningstaking: Studien viser at internasjonale konvensjoner legitimerer delvis inkompatible kunnskapsformer (om biologisk mangfold på den ene siden og beskyttelse av tradisjonell kunnskap / urfolkskunnskap på den andre siden). Dette fører til konflikter og vanskeligheter i implementeringen av dem. De forskjellige konvensjonene har forskjellige intensjoner, og er til en viss grad motstridende. Disse motsetningene forsterkes gjennom måten konvensjonene er oversatt til nasjonal politikk ved at det skapes mangesidige mål. Dette bidrar også til konflikter mellom nivåene (nasjonalt/regionalt). Regionale organer har «fått overført ansvar uten reell beslutningsmyndighet» (Sjölander-Lindqvist et al., 2020, s. 15, vår overs.) Ulike aktører handler dessuten ut fra sine spesifikke kunnskapssfærer (enten basert på vitenskap eller lokal, erfaringsbasert kunnskap). Videre mangler aktørene gjensidig aksept for gyldigheten og påliteligheten til den kunnskapen om store rovvilt som forskere og reineiere har. Når de regionale organene prøver å treffe egne beslutninger, bl.a. ut fra lokal erfaringsbasert kunnskap, opplever de å bli overstyrt av sentralbyråkratiene.

Utfallet blir at de regionale organene forventes å fungere som utvidelser av sentralstaten, og kun sitter igjen med ansvar oppover. På sentrale nivåer aksepteres bare argumenter innenfor den vitenskapelig baserte kunnskapssfæren som gyldige. (Sjölander-Lindqvist et al., 2020, s. 15, vår overs.)

De empiriske funnene viser at integrering av forskjellige kunnskapstyper er utfordrende. Selv om demokratisk desentralisering ansees som en nøkkelkomponent i god forvaltning, dokumenterer studien en fragmentert situasjon. Lærdommen fra sammenligningen er at «det er behov for å utjevne ubalanse mellom forskjellige kunnskapssfærer, men også i forhold til ansvarlighet oppover/nedover for å unngå økt mistillit til både ledelse og politikk» (Sjölander-Lindqvist et al., 2020, s. 15, vår overs.).

To andre studier bekrefter det bildet den norsk/svenske studien gir. En nordisk studie (Sandström et al., 2018) fant at forsøkene på å styre 
og håndtere komplekse sosioøkologiske sammenhenger knyttet til store rovdyr i Finland, Norge og Sverige gjennom desentraliserte eller samarbeidende tilnærminger har vist seg å være en krevende oppgave. Et felles problem for de tre landene er vanskeligheten med å delegere eller desentralisere myndighet fra det nasjonale til regionale nivåer. Til tross for a mbisjonene om å innføre samarbeidende eller desentraliserte tiltak, viste gjennomgangen at vedkommende myndighet primært holder seg til det sentrale nivået. Eventuelle desentraliserte oppgaver fokuserer hovedsakelig på konfliktstyring, og dermed er regionale eller lokale nivåer ansvarlige for implementeringen av allerede definerte policyer. «Det er begrensede muligheter for å tilpasse disse retningslinjene til lokale behov og ønsker» (Sandström et al., 2018, s. 266, vår overs.).

En europeisk studie som i tillegg til Norge, Sverige og Finland også omfatter Nederland samt utvalgte regioner i Tyskland og Spania, viser at rovdyrpolitikken i landene har tegn på manglende vertikal og horisontal sammenheng i utformingen av politiske prosesser, svak konsistens mellom mål og utpekte politiske virkemidler, og som en konsekvens mangler helhet:

Studien konkluderer med at å skape konsekvente, sammenhengende og omfattende policy-mikser som bygger på flere mål krever at man går vekk fra sektorutviklet politikkutvikling, mot en helhetlig, systemisk tilnærming, sterke samarbeidsstrukturer på tvers av politiske grenser og regioner, inkludering av ulike interessenter og konstant omsorg og oppmerksomhet for å adressere alle mål (de Boon et al., 2020, vår overs.).

\section{Klimaendringer og tap av rein til rovvilt}

Under gode beiteforhold om vinteren kan reinflokken gå samlet og bevege seg gjennom landskapet mens den beiter på de tilgjengelige beiteressursene. Da kan reindriftsutøverne holde tilsyn med flokken gjennom «kantgjeting». Dette er å kjøre rundt reinflokken med snøskuteren mens de ser til at dyra ikke sprer seg i småflokker, men går samlet. Under denne kantgjetingen har de mulighet til å oppdage spor etter rovvilt i nærheten 
av reinflokken. Denne tilstedeværelse i nærheten av reinflokken kan også ha en tapsforebyggende effekt ved at rovviltet vil trekke seg unna. Ved vanskelige vinterbeiteforhold er et tradisjonelt tiltak å la reinflokken spre seg i småflokker over større beiteområder for å øke sannsynligheten for at samtlige dyr skal klare å finne tilstrekkelig med beite. Når reinen går spredt over store områder er det ikke mulig for reindriftsutøverne å gjennomføre effektiv «kantgjeting». Dermed vil reinsdyra være mye mer eksponert for rovvilt. I områder med aktive stammer av rovvilt vil sannsynligheten for tap av rein derfor øke betydelig. Enkelte distrikt har de siste årene, på grunn av store tap til rovvilt, gjennomført tilleggsfôring av reinen deler av vinteren for å klare å holde den samlet for å redusere disse tapene. Dermed havner de i en situasjon der de på grunn av rovviltet ikke kan la reinen livnære seg på de naturlige beiteressursene i deler av reinbeitedistriktet. Med de pågående klimaendringene kan mange reinbeitedistrikt med økende hyppighet havne i en slik situasjon der kombinasjonen vanskelige vinterbeiteforhold og rovvilt gjør driftsforholdene svært vanskelige.

\section{Tap og arealinngrep}

I vårt bidrag i kapittel 2 («Reindriftas sårbarhet») i denne boka har vi analysert hvordan summen av naturinngrep akkumuleres og bidrar til stadig mer omseggripende utfordringer i drifta. Foran har vi referert til podkast med distriktsleder Mats Pavall i Duokta reinbeitedistrikt om tap av rein til rovdyr. I samme podkast (Lian, 2020) setter Pavall tapene i sammenheng med arealinngrep, både små og store. Foruten effekten av rekreasjonsbruken til Bodøs befolkning skaper også Nordlandsbanen store problemer og dreper mange rein hvert år.

Det pågår kontinuerlig FoU-arbeid i Norge med mål å redusere omfanget av tap av rein til fredet rovvilt. GPS-sendere på rein (se figur 2) kan muligens hindre rovdyrangrep. Pavall forteller i podkasten at senderne har hatt en tapsreduserende virkning det første året klavene var på, men det spørs om virkningen vil vare. Rovviltet har en stor tilpasningsevne og vil sannsynligvis over tid finne ut at GPS-senderne ikke er «noe å bry seg om». 


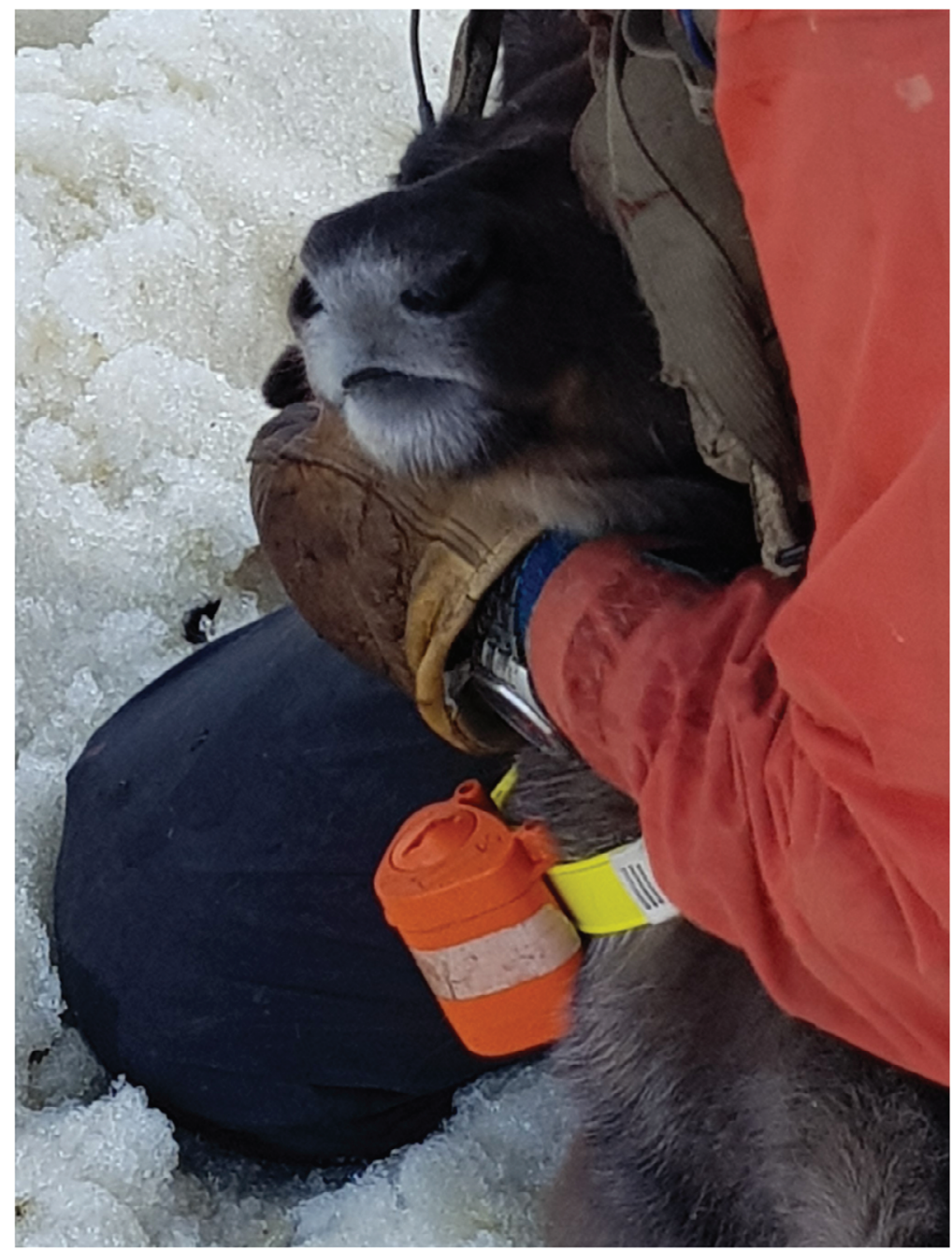

Figur 2. GPS-sender som blir hengt i plastklave rundt halsen på reinkalv (foto: Svein Morten Eilertsen).

\section{Samfunnsendring}

For å forstå konfliktene omkring rovdyrforvaltningen må man kjenne historia. Reineier Per Mathis Oskal ${ }^{3}$ har sammenliknet rovdyrsituasjonen i Troms på 1970-tallet og nå slik:

3 På intervjutidspunktet (2016) bl.a. medlem av det sentrale Rovviltutvalget nedsatt av Miljøverndepartementet. 
På 1970-tallet var det nesten ikke rovvilt. Det var vanskelige vintre da også, men selv om man kunne miste mye rein fikk man opp flokken i løpet av et par år fordi det ikke var andre farer. I dag klarer man knapt å holde reintallet med en veldig lav produksjon, med tilleggsfôring gjennom vinteren og gjeting fra november til juni, delvis døgngjeting, vi bruker veldig mye tid og ressurser, er hos flokken hver dag, likevel har man de tapene. (Riseth \& Johansen, 2019, s. 111)

Et bidrag i boka Distriktsopprør. Periferien på nytt i sentrum handler om ulvekonflikten og det norske samfunnet. Jon Nautstdalslid (2020) analyserer hvordan grunnleggende materielle strukturer i det norske samfunnet har endret seg i løpet av sju tiår:

... ei utvikling bort frå ein ressursbasert økonomi til ein økonomi og eit samfunn som i større grad er dominert av postmaterielle næringar og tilhøyrande kulturytryngar og verdiar. Dette har skjedd på kostnad av den ressursbaserte periferiens politiske og kulturelle styrke. (Naustdalslid, 2020, s. 278)

Forfatteren stiller opp to natursyn mot hverandre. Det tradisjonelle natursynet innebærer at naturen er ramme rundt menneskelig aktivitet og en kilde til bruk og høsting og grunnlag for primærnæringer og ressursutnytting. I motsetning til dette står det postmoderne natursynet, hvor naturen har sin egen eksistens utenfor samfunnet og bør få leve sitt eget liv mest mulig uberørt av mennesker med villmark som den høyeste og ideelle formen for natur. Leena Soupajärvi (2003) har gjort en liknende analyse av natursyn og naturbruk i finsk Lappland for samme periode. Riktignok opererer hun med en tredeling (se figur 3), men hun framstiller det postmoderne natursynet på samme måte som Naustdalslid.

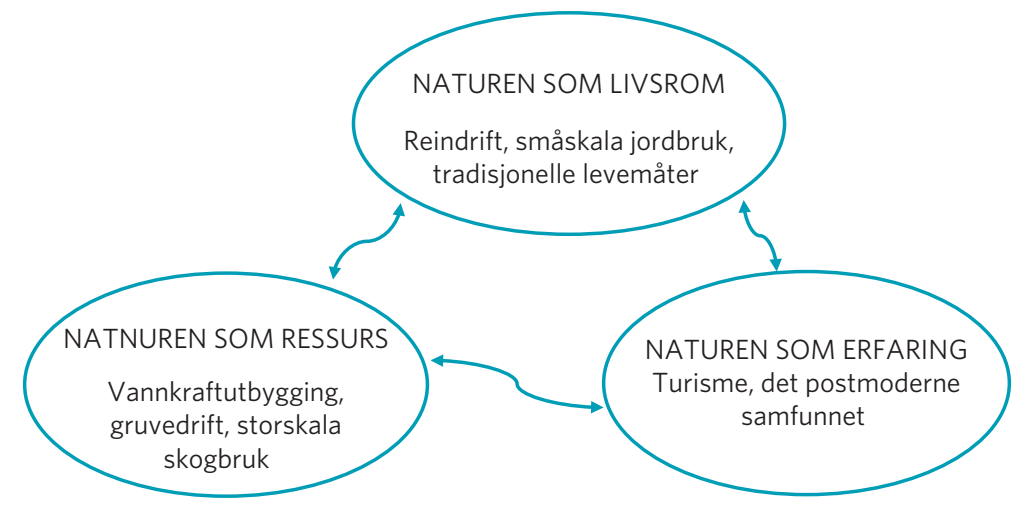

Figur 3. Konkurrerende næringer og natursyn. (Fritt etter Soupajärvi, 2003:205). 
Reindrifta og tradisjonelle bygdenæringer som bl.a. sauebeite tilhører den øvre ellipsen hos Soupajärvi (2003, s. 205, figur 3) og ser naturen som et levd rom. Sverre Fjellheim (1995) har utdypet samisk forståelse ved å si at landskapet samene bruker er et kulturlandskap skapt i en dynamisk prosess mellom mennesker, tid og rom. Det blir derfor en påfallende kontrast mellom mennesker som lever i og av naturen og mennesker som kommer på besøk for rekreasjon (nede til høyre i figur 3). I tillegg kommer reindrifta og samisk naturbruk i skvis med moderne ressursuttak av naturen (nederst til venstre i figur 3). Andre fysiske arealinngrep må sees på samme måte (Riseth, 2005).

\section{Oppsummering og konklusjon}

Som nevnt innledningsvis spilte Bernkonvensjonen en viktig rolle for at Norge fikk viltloven (nå naturmangfoldloven) og utviklet dagens rovviltforvaltning. Det er likevel viktig å være bevisst at selv om et land ratifiserer en internasjonal konvensjon, så er det intern politikk som avgjør hvordan konvensjonen forvaltes i det enkelte land. Norge har også ratifisert mange andre internasjonale konvensjoner. Vi finner grunn til å sette spørsmålstegn ved hvorvidt Norges praktisering av Bernkonvensjonen kan være i strid med andre internasjonale forpliktelser Norge har påtatt seg. En sak er at beitedyr er viktige for annet biologisk mangfold (Risvoll et al., 2016); viktigere er det nok at reindrifta er sentral for samene som urfolk. En grenseoppgang mellom urfolksvern og Bernkonvensjonen ble etterlyst for over tjue år siden (Sletten, 1997a), men er fortsatt ikke satt på den politiske dagsordenen. At det kan være slik, bekreftes også av de internordiske og europeiske studiene referert til over (særlig SjölanderLindqvist et al., 2020).

Med henvisning til FN-konvensjonen om sivile og politiske rettigheter, artikkel 27 SP 27 (1966) har juristen Jon Gauslaa (2018) gjort en folkerettslig vurdering av forholdet mellom rovviltbevaring og samisk materiell kulturutøvelse. Han anfører bl.a. at «[om] dagens norske rovdyrforvaltning i reindriftsområder er i strid med SP artikkel 27 vil bero på tapsomfanget i samisk reindrift forårsaket av rovdyr, sammenholdt med erstatningsordninger og fellingsregimer» (Gauslaa, 2018, s. 15-16). 
Kjernepunktet i en konkret vurdering er hvorvidt rovdyrbelastningen blir så stor at den «rammer kulturutøvelsen på en utilbørlig måte» (Gauslaa, 2018, s. 8). Det tapsomfanget og den frustrasjonen over det som alle 12 reinbeitedistrikter i Nordland ga uttrykk for i uttalelsen 13. oktober 2020 tyder på at tapsnivået Gauslaa stiller som krav kan være oppfylt.

Det gir grunn til ettertanke at det ikke bare er sauebønder, reindriftssamer og reindriftsforskere som kritiserer rovdyrpolitikken. Som vist peker også rovdyrforskere som har evaluert rovviltforvaltningen på oppdrag fra myndighetene at de finner at forutsetningene for forvaltningsmodellen ikke er til stede. Vi kan slå fast at det er behov for omfattende omlegginger av rovviltforvaltningen av Norge.

Vi skal ikke fremme noe konkret forslag om hvordan dette bør gjøres. Hovedpoenget er at for å sikre en levekraftig reindriftsnæring, er rovdyrstammene særlig i Nordland, Troms og Nord-Trøndelag for store. Det innebærer bl.a. at man, basert på reindriftsnæringens tradisjonelle kunnskap/observasjoner som holdes utenfor rovviltforvaltningens beslutningsgrunnlag, må erkjenne at rovdyrstammene er større enn forvaltningen har oversikt over, og at hverken jerv eller gaupe er truet. Det er også mye som tyder på at både kongeørn og havørn kan tåle betydelige reduksjoner av stammene. Det er også viktig at forvaltningen etterlever naturmangfoldlovens $₫ 8.2$, som faktisk opphever naturvitenskapens kunnskapsmonopol og benytter seg av reindriftssamenes kunnskap om rovdyrene og de skadene de påfører reindrifta (Eira \& Sara, 2017). Dette er særlig viktig i forhold til $ø$ rn, som er lite studert av rovdyrforskerne (bearbeidet fra Riseth \& Johansen, 2019:118-119).

De sammenliknende studiene referert over viser imidlertid at det spesielt to forhold som må sikres. For det første må det skje en reell delegasjon av både makt og ansvar til regionalt nivå, slik at bestemmende organer kan ivareta mangesidige hensyn basert på likeverdig dialog mellom de involverte. Det andre er nettopp at alle beitebrukeres lokalkunnskap, inklusive reineiernes tradisjonelle urfolkskunnskap, anerkjennes og legges til grunn for framtidig rovdyrforvaltning. 


\section{Referanser}

Agrawal, A. (1995). Dismantling the divide between indigenous and scientific knowledge. Development and Change, 26(3), 413-439. https://doi.org/10.1111/ j.1467-7660.1995.tboo56o.x

Auestad, G. E. \& Nilsen, A. A. (2010, 17. desember). - Må skyte fleire ulv og bjørn. NRK. https://www.nrk.no/norge/bygdefolk-demonstrerer-i-oslo-1.7429517

de Boon, A., Sandström, C., Arbieu, U., Hansen, I., Lehnen, L., Marino, A., PohjaMykrä, M., Risvoll, C., Strand, G.-H. \& Rønningen, K. (2020). Governing dual objectives within single policy mixes: An empirical analysis of large carnivore policies in six European countries. Journal of Environmental Policy \& Planning, 23(4), 399-413. https://doi.org/10.1080/1523908X.2020.1841614

Bernkonvensjonen. (1979). Konvensjon vedrørende vern av ville europeiske planter og dyr og deres naturlige leveområder ETS nr. 107 (19-09-1979). Lovdata. https:// lovdata.no/traktat/1979-09-19-1

Danell, Ö. (2010). Renskötsseln och rovdjuren (Rangifer report 14/2010:78-79).

Eira, I. M. G. \& Sara, M. N. (2017). Reindriftsnoeringens erfaringsbaserte kunnskap om reindrift og rovvilt (Rapport). Sametinget. https://samas.no/se/a/ reindriftsnaeringens-erfaringsbaserte-kunnskap-om-reindrift-og-rovvilt

Fjellheim, S. (1995). Det samiske kulturlandskapet (Foredrag Saemien Våhkoe Røros 1994). I S. Fjellheim (Red.), Fragment av samisk historie (s. 58-81). Sør-Trøndelag og Hedmark reinsamelag.

Gauslaa, J. (2018, 16. mars). Rovdyrvern og menneskerettigheter i reindriftsområder [Kurs]. Juristenes utdanningssenter, Alta.

Haugerud, R. (2010). Bærer kostnaden for økende rovdyrbestand. Reindriftsnytt, (4), 13-14.

Hætta, K. (2012, 15. november). - Reindrifta i Jämtland og Trøndelag nær en kollaps. NRK Sápmi. https://www.nrk.no/sapmi/_-reindrifta-naer-kollaps-1.8398011

Klein, D. R., (1968). The introduction, increase and crash of reindeer on St. Matthew Island. Journal of Wildlife Management, 32, 350-367.

Karlsson, J., Støen, O.-G., Segerström, P., Stokke, R., Persson, L.-T., Stokke, L.-H., Persson, S., Stokke, N. A., Persson, A., Segerström, E., Rauset, G.-R., Kindberg, J., Bischof, R., Sivertsen, T. R., Skarin, A., Åhman, B., Ängsteg, I. \& Swenson, J. (2012). Björnpredation på ren och potentiella effekter av tre förebyggande åtgärder Ett samarbetsprojekt mellan Viltskadecenter, Skandinaviska björnprojektet, Udtja skogssameby och Gällivare skogssameby (Viltskadecenter rapport 2012:6). Viltskadecenter, Grimsö Forskningsstation.

Klima- og miljødepartementet. (2020, 28. oktober). Rovdyr i Noreg [Artikkel]. https://www.regjeringen.no/no/tema/klima-og-miljo/naturmangfold/ innsiktsartikler-naturmangfold/rovvilt-og-rovviltforvaltning/id2076779/ 
Krange, O., Odden, J., Skogen, K., Linnell, J. D. C., Stokland, H. B., Vang, S. \& Mattisson, J. (2016). Evaluering av regional rovviltforvaltning (NINA rapport 1268). Norsk institutt for naturforskning. http://hdl.handle.net/11250/2391094

Landbruksdirektoratet. (2019). Ressursregnskap for reindriftsnoeringen. For reindriftsåret 1. april 2018-31. mars 2019 (Rapport 34/2019). Landbruksdirektoratet.

Landbruksdirektoratet. (2020). Ressursregnskap for reindriftsnoeringen. For reindriftsåret 1. april 2019-31. mars 2020 (Rapport 43/2020). Landbruksdirektoratet.

Lian, S. (2020, 21. august). Tett på: Den siste reineier [Podkast]. NRK Sápmi. https:// radio.nrk.no/podkast/tett_paa

Mattisson, J., Odden, J., Strømseth, T. H., Rauset, G. R., Flagstad, Ø. \& Linnell, J. D. C. (2015). Gaupe og jerv i reinbeiteland. Sluttrapport for Scandlynx Troms og Finnmark 2007-2014 (NINA rapport 1200). Norsk institutt for naturforskning. http://hdl.handle.net/11250/2367530

Naturvernforbundet. (2019, 4. januar). Rovdyr. Naturvernforbundet.no. https:// naturvernforbundet.no/naturvern/vern_av_arter/rovdyr/

Naustdalslid, J. (2020). Ulvekonflikten og periferiens politiske transformasjon. I R. Almås \& E. M. Fuglestad (Red.), Distriktsopprør. Periferien på nytt i sentrum (s. 276-294). Dreyer.

Nieminen, M., Norberg, H. \& Maijala, V. (2011). Mortality and survival of semidomesticated reindeer (Rangifer tarandus tarandus $L$.) calves in northern Finland. Rangifer, 31, 71-84.

Norberg, H., Kojola, I., Aikio, P. \& Nylund, M. (2006). Predation by golden eagle Aquila chrysaetos on semi-domesticated reindeer Rangifer tarandus calves in northeastern Finnish Lapland. Wildife Biology, 12, 393-402.

Odden, J., Mattisson, J., Langeland, K., Stien, A. Linnell, J. D. C. \& Tveraa, T. (2018). Rovdyr og rein i Midt-Norge. Sluttrapport (NINA-rapport 1380). Norsk institutt for naturforskning. https://brage.nina.no/nina-xmlui/handle/11250/2494308

Ree, M. (2008, 12. september). 40 år siden fredningen av havørn og kongeørn. Norsk ornitologisk forening. https://www.birdlife.no/fuglekunnskap/nyheter/?id=357

Riseth, J. Å. (2014). Ei bærekraftig reindrift? I Samiske tall forteller 7 (Rapport 1/2014, s. 52-100). Sámi Allaskuvla/Samisk Høgskole.

Riseth, J. Å. (2005). Nature protection and the colonial legacy - Sámi reindeer management versus urban recreation: The case of Junkerdal-Balvatn, Northern Norway. I T. Peil \& M. Jones (Red.), Landscape, law and justice. Proceedings of a conference organised by the Centre for Advanced Study at the Norwegian Academy of Science and Letters, Oslo 15-19 June (s. 173-186). The Institute for Comparative Research in Human Culture. Novus forlag.

Riseth, J. A.. \& Johansen, B. (2019). Inngrepsanalyse for reindrifta i Troms (Rapport 23/2018). Norut. https://tromsfylke.no/media/152219/rapport-inngrepsanalysetroms_very-last-final.pdf 
Risholm, T. (2017, 31. juli). Enorme tapstall: En tredjedel av all reinen blir drept på beite i Nordland. Helgelendingen. https://www.helg.no/reindrift/rovdyr/ nordland/enorme-tapstall-en-tredjedel-av-all-reinen-blir-drept-pa-beite-inordland/s/5-24-216002

Risvoll, C., Fedreheim, G. E. \& Galafassi, D. (2016). Trade-offs in pastoral governance in Norway: Challenges for biodiversity and adaptation. Pastoralism, 6. https://doi.org/10.1186/s13570-016-0051-3

Rovdata. (2020). Bestandsstatus - jerv. Rovdata.no. https://rovdata.no/Jerv/ Bestandsstatus.aspx

Sikku, O. J. \& Torp, E. (2008). Vargen är värst: Traditionell samisk kunskap om rovdjur. Jamtli förlag.

Sandström, C., Sjölander-Lindqvist, A., Pellikka, J., Hiedanpää, J., Krange, O. \& Skogen, K. (2018). Between politics and management: Governing large carnivores in Fennoscandia. I T. Hovardes (Red.), Large carnivore conservation and management: Human dimensions (s. 269-290). Routledge. https://doi.org/ $10.4324 / 9781315175454$

Sjölander-Lindqvist, A., Risvoll, C., Kaarhus, R., Lundberg, Aa. K. \& Sandström, C. (2020). Knowledge claims and struggeles in decentralized large carnivore governance: Insights from Norway and Sweden. Frontiers in Ecology and Evolution, 8. https://doi.org/10.3389/fevo.2020.00120

Skjenneberg, S. \& Slagsvold, L. (1968). Reindrifta og dens naturgrunnlag. Universitetsforlaget.

Skogen, K., Figari, H. \& Krange. O. (2010). Meninger om rovviltforvaltning (NINA rapport 607). Norsk institutt for naturforvaltning. http://hdl.handle. net/11250/2642426

Sletten, H. (1997a, 8. januar). Sørsamene - trenger vi dem? [Kronikk]. Trønder-Avisa.

Sletten, H. (1997b). Rovdyrkonflikten: Noering, forsking og forvaltning. Rapport fra fagseminar i reindrifta. Kautokeino 10.-12. oktober 1997 (s. 103-107). Reindriftas fagråd.

Soupajärvi, L. (2003). Competing industries and contested nature in Finnish Lapland after World War II. I F. Möller \& S. Pehkonen (Red.), Encountering the North (s. 203-220). Ashgate.

St. meld. nr. 15 (2003-2004). Rovvilt i norsk natur. Klima- og miljødepartementet. https://www.regjeringen.no/no/dokumenter/stmeld-nr-15-2003-2004-/id403693/

Strand, G. H. (Red.). (2016). Rovviltbestandenes betydning for landbruk og matproduksjon basert på norske ressurser (NIBIO rapport 2:63). Norsk institutt for bioøkonomi. http://hdl.handle.net/11250/2391081

Statsforvalteren i Nordland. (2020, 30. oktober). Felles uttalelse fra Reindrifta $i$ Nordland. https://www.statsforvalteren.no/siteassets/fm-nordland/dokumentfmno/landbruk-og-mat-dokumenter/reindrift-dokumenter/18-1575-uttalelse.pdf 
Svendsen, T. O. (2019, 3. mai). Bjørnekult. I Store norske leksikon. https://snl.no/ bjørnekult

Svendsen, T. O. (2020, 29. desember). Veiviseren. I Store norske leksikon. https://snl. no/Veiviseren

Teigen, H. \& Skjeggedal, T. (2015). Fjellpolitikk. Eit historisk tilbakeblikk.

I T. Skjeggedal \& K. Overvåg (Red.), Fjellbygd og Feriefjell - 50 år etter (s. 33-53). Fagbokforlaget.

Tveraa, T., Ballesteros, M., Bårdsen, B.-J., Fauchald, P., Lagergren, M., Langeland, K., Pedersen, E. \& Stien, A. (2012). Rovvilt og reindrift: Kunnskapsstatus i Finnmark (NINA Rapport 821). Norsk institutt for naturforskning. https://www.nina.no/ archive/nina/PppBasePdf/rapport/2012/821.pdf

Verstad, A. B. (2020, 22. august). Mats kan bli tvunget til å bryte med en flere hundre år gammel familiearv. NRK Sápmi. https://www.nrk.no/sapmi/xl/mats-jonaspavall-onsker-ikke-a-viderefore-reindrifta-til-sine-barn-1.15109259

Åhman, B., Svensson, K. \& Rönnegård, L. (2014). High female mortality resulting in herd collapse in free-ranging domesticated reindeer (Rangifer tarandus tarandus) in Sweden. PLoS ONE, 9(10). https://doi.org/10.1371/journal.pone.0111509 


\title{
KAPITTEL 9
}

\section{Stien i endring? Om det godes paradoks}

\author{
Odd Inge Vistad
}

\author{
Norsk institutt for naturforsking (NINA)
}

\begin{abstract}
The trail is the most important helping measure in friluftsliv (i.e. outdoor recreation or OR), mainly since walking in the neighborhood or local forest is the most frequent friluftsliv activity. Historically, trails were linear structures through the landscape to help people move from A to B for various purposes, and generally a trail was the result of systematic trampling along a preferred durable route. In OR, the activity and the experiences along the trail are often regarded as more important than moving from A to B. Preference studies in Norway have shown that a narrow, simple, dirt trail through an open, mature forest is the most attractive type of trail. Developed, graveled and broader trails are visually less attractive, likewise for wooden boardwalks. Today, new trails and restored trails seem to be systematically developed, broadened and hardened with gravel, wooden boardwalks or a stone surface. And there are many good reasons for this, like limiting erosion and ground impact, stimulating OR volume and thereby public health, helping disabled persons to access nature, building attractions for tourists, stimulating new activities (like biking), maintaining OR access in built-up areas, etc. A new "trail normality" is on the way, and I see (potential) losses: The friluftsliv culture and human-nature relation are changing, and a "graveled nature" is likely to be less attractive for children. Constant trail maintenance is needed, which takes the attention away from high quality friluftsliv landscape and replaces it with friluftsliv infrastructure. A heavy responsibility rests on the responsible OR management authorities in balancing various $\mathrm{OR}$ and trail measures.
\end{abstract}

Keywords: outdoor recreation culture, friluftsliv, dirt trail, developed trail, trail preference, public health, trail impacts and management, children and nature, trail tourism, trail maintenance

Sitering: Vistad, O. I. (2021). Stien i endring? Om det godes paradoks. I F. Flemsæter \& B. E. Flø (Red.), Utmark $i$ endring (Kap. 9, s. 239-264). Cappelen Damm Akademisk. https://doi.org/10.23865/noasp.151. ch9

Lisens: CC BY-NC-ND 4.0 


\section{Inngang}

Les med dette i tankane: Skrivaren er prega av oppveksten på garden i skogkanten i indre Telemark. Eg var mykje i skogen, men me dreiv ikkje med 'friluftsliv'. Me leika «gøymi», cowboy og indianar, bygde barhytter, lærde oss fuglar og planter, samla på fugleegg. Det var mange stiar og grasgrodde vegar i skogane, men som ungar i leik var me lite avhengige av dei. I ettertid står dei likevel fram som lokale trivselsliner, for han som meiner å vere fødd ein generasjon for seint - minst. Desse linene fortalde historiesnuttar om utmarksbruk og tidlegare tider. Dei eldre kunne forklare og fortelje. Om dette er nostalgi, interesse, preging eller berre å høyre til, spelar inga rolle for meg - det berre er der. Men det kan spele ei rolle for deg, som lesar og tolkar. Eg flytte frå bygda, studerte naturforvaltning og har forska ein god mannsalder på friluftsliv.

Det er inspirasjon i forfattar Einar Øklands programerklæring: « $\AA$ skrive godt er å trenge seg gjennom alt ein veit, fram mot det ukjende. Ein kan ikkje vite før ein veit» (Grepstad, O. 2020).

\section{Kva er ein sti?}

Far min - fødd i 1920 og etter kvart bonde på den vesle heimegarden snakka om «dei gode vegjine på heii». På heii ligg dei tre gardsstøylane våre og støylane til 8-9 andre gardar.

Etter bratte Heiberget flatar skoglendet ut. Fyrst kjem ein til Stogebu, seinare til Torsstøyl og lengst inne Herrvasstøylen (figur 1). Alle ligg høgt i skogbandet. Hit drog dei med kyrne kvar sommar og «låg der» gjennom slåttetida. Graset slo dei med stuttljå, frå støyl til støyl og slåtte til slåtte - innover, turka det helst på bakken, hesja om dei måtte, og bar høyet inn i høybuene. Så henta dei høyet med hest på ettervinteren. Dette livet tok gradvis slutt etter krigen; der heng enno bilete av kong Haakon over sengene. I 1954 vart siste hesten på garden selt, traktoren kjøpt, og eg vart fødd. Då hadde det enno ikkje kome veg (kjerreveg) til heii.

For dette er poenget: Det far min kalla veg, er det som eg og folk flest kallar sti, eller stig. Og den gjekk ikkje berre mellom støylane. «Vegjine» 
gjekk i kross og krak mellom støylar, buer, slåtter, fiskevatn - og Dansarberget (som er nett det det høyrest ut som). Og dei som gjekk der, kjende heii ut og inn og trong sjeldan 'vegen' for å finne fram, men den var lettast og tryggast å gange både for folk og fe, for å kome dit ein skulle, for å få gjort det ein skulle - slik ein hadde gjort i generasjonar. For det var jo det som var poenget; ein gjekk fordi ein hadde ærend. "Går man de gamle seterveier, kan man oppleve at føttene finner fram av seg selv, at hver stein $i$ terrenget synes å ligge på sin rette plass, formet av tusenvis av fotsteg» (Steinsland, 2020). Christensen (2002) skriv om sirklar (aktivitetsfelt) og punkt (stader som folk oppsøkjer) i landskapet, knytt i hop av liner (transportårer - her stiar). I hovudsak var det snakk om trakka råk, lagt slik at ein helst gjekk utanom myrar, gjørmehol og bratte grusrabbar. Det eg kallar veg (= skogsbilveg), kom til heii fyrst på 1970-talet. Då tok ein ikkje opp att støylslivet, men ein hogg skogen og køyrde ut tømmer. Mange støylsvollar og dei fleste «vegar» (les: stiar) var alt då tilgrodde med finnskjegg, bjørkekjerr og endå gran; sjå bileta av Herrvasstøylen (figur 1).

Stiane hadde ein funksjon. Dei var eit hjelpemiddel for å kome trygt fram for den som var ukjend, og dei gjorde det lettare å gå, ri eller klyvje også for den som var godt kjent. Men det kunne sjølvsagt vere «dårleg standard» også i gamal tid - som det var for Ivar Aasen i 1853. Me er stadig i indre Telemark, og han må kome seg frå Mo til Vinje - aleine til fots. Han skreiv minnediktet Byrte-heidi (Aasen, 1976), og byrja det slik: "Vandt er aa vita / Vegen til Vinje: / Grunnen er groen / med gras paa alla sidor; / inkje Gjeitar-gòta / ein Gong te finna! / Kvar i vide Verdi er Vegen til Vinje?» (mi utheving - veg var truleg sti).

Aasen kom på villstrå. Og ordvalet mitt er ikkje tilfeldig. "Grunnen er groen med gras paa alla sidor», skriv han så observant. Når folk, fe eller ville dyr går systematisk same ruta, så slitest plantene bort og stien blir til; ordet sti kjem jo av stig eller steg. Men det er ikkje alt planteliv som slitest like fort. Urter og lyng forsvinn fortare enn gras, og det same gjeld andre vegen: Grasvekstar kjem fortare inn att i stibanen enn lyng og urter, når det blir færre steg og stien gror til. Grasartar er nemleg stødige mot trakk (ikkje tilfeldig at det er gras som dominerer på plenen og i parkar). Ordet villstrå har minst to tydingar, og i dette tilfellet heng dei i hop: Det er eit utbreidd lokalnamn for grasarten finnskjegg (Nardus stricta) - det svært 


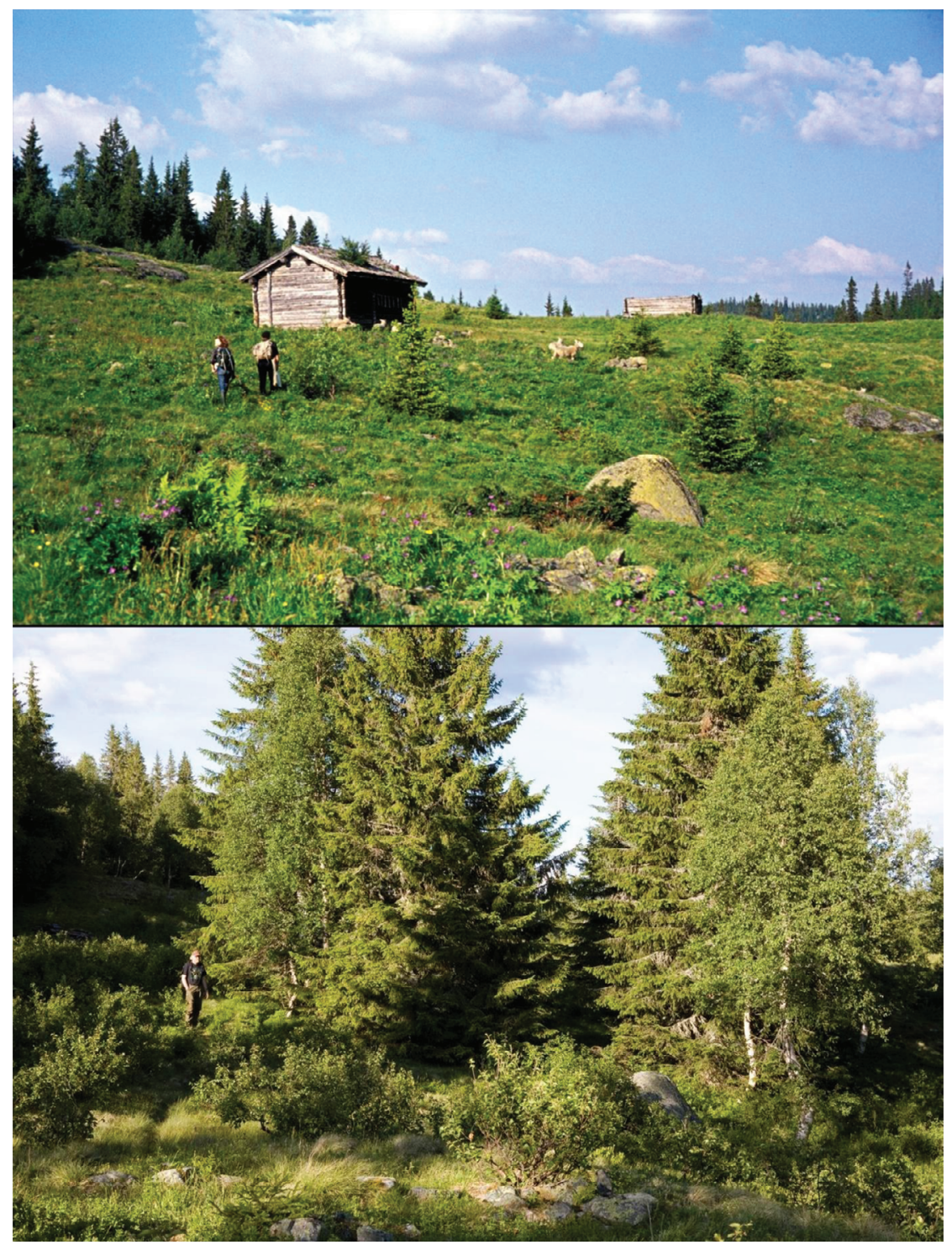

Figur 1. To bilete av Herrvasstøylen, tatt frå same punkt. Øvst 1972 (foto: Kjetil Vistad), nedst 2008 (foto: Oskar Puschman).

nøysame og vanlegaste graset i desse heitraktene i indre Telemark. Finnskjegg invaderer stien ganske fort, og det blir vanskeleg å skilje om det er ein folkesti eller eit dyretrakk som gror til; altså kan ein kome 'på villstrå' (dvs. 'på ville veier', ifylgje ordboka). Me spør av og til: Skal du den vegen eller den vegen? Og me meiner ikkje ein fysisk veg til å gå på, 
men kva retning ein skal. Kanskje var Ivar Aasen forvirra på båe plan når han spør: Kvar $i$ vide Verdi er Vegen til Vinje?

\section{Kva har særprega stien, over tid?}

Stien var ei kommunikasjonsåre, ei hjelp til å kome fram. I dag - i friluftslivet - er det mest sjølve aktiviteten på stien og opphaldet $i$ naturen som er poenget, sjeldnare det å kome fram. Det me kallar friluftsliv, blir gjerne delt inn i aktivitetar. Men det er ikkje opplagt at den viktigaste sorteringa i friluftslivet går mellom aktivitetane. Folk har ulike motiv, ulik trivsel og meiningar knytt til friluftslivet sitt, som kan gå på tvers av aktivitetar (Vistad, 1995; Svarstad, 2010). Dette er noko av bakgrunnen for å problematisere 'stien' - som eg no er i gang med. Men altså aktivitetane: Med jamne mellomrom (3-4 år) kartlegg SSB kor mange som driv med dei ulike aktivitetane, og kor hyppig (Statistisk Sentralbyrå, 2020). Dei mest utbreidde aktivitetane er korte gåturar nær der ein bur; rundt $77 \%$ (2020) av alle vaksne gjer det - ofte eller av og til - og omlag like mange går kortare turar i skogen eller på fjellet (79 \% i 2020). Turane blir gjort på stiar, turvegar, fortau og andre ferdselsårer. Det er ganske få som på måfå berre «går inn i skogen» (slik eg gjorde som liten) eller «over fjellet» - ein held seg helst til stien eller ruta (Gundersen et al., 2015). Slik sett er stien i nærmiljøet det viktigaste enkelt-tiltaket for friluftslivet. Så enkelt, så billig og så utbreidd - så lenge turmiljøet rundt stien også er attraktivt.

Utbreidd ja, men ingen har vel starta t.d. eit tidsskrift om noko så kvardagsleg, teknologifritt og sensasjonslaust som nærturen og stien? Ein aktivitet som berre dreiar seg om å halde på, og i eit miljø så kjedeleg og livsviktig som nærmiljøet; like trivielt som å skrive om 'Dørstokken heme' (Alf Prøysen starta likevel der!). Derimot finst det plenty foreiningar og glansa trykksaker når me kjem til det utstyrs- og prestasjonsbaserte friluftslivet som jakt og fiske, og etterkvart det moderne og actionprega friluftslivet med spekteret av ski, brett og syklar - under samlemerket 'Fri flyt'. Og på toppen av dette: sterke kommersielle interesser knytt til utstyr, bra med testosteron og verda som arena. Storokse i siktet er lettare å selje enn stille steg på stien. Kvardagsturen levde lenge sitt usynlege, men livsviktige liv - ein slags friluftslivets sikringskost. 
Men det skjer noko utover 2000-talet. 2005 var eit såkalla Friluftslivets år (FÅ), gjennomført av FRIFO (Friluftslivets Fellesorganisasjon, i dag Norsk Friluftsliv), under mottoet «Friluftsliv for alle - hver dag», finansiert av Miljøverndepartementet (MD). Ein prioriterte friluftsliv og nærmiljøet. Året etter var eg med og evaluerte gjennomføringa (Vistad et al., 2006). Der fekk me TNS Gallup til å stille nokre spørsmål om FÅ i sitt Natur og miljøbarometer. Kva trudde folk hadde vore hovudfokuset i Friluftslivets år, og kva meinte dei det burde ha vore - nærmiljøet eller fjellet? Førtifire prosent trudde det var nærmiljøet, medan $77 \%$ sa at det burde ha vore nærmiljøet. Førti prosent trudde det var fiellet, berre $17 \%$ meinte det burde ha vore fjellet. Eg hugsar éin svara: Sidan det er Miljøverndepartementet som står bak så var det sikkert fjellet. Men både det offentlege og organisasjonane retta seg stadig meir mot dagleglivet og nærmiljøet. DNT - sjølve fjellsymbolet innan friluftslivet - hadde starta med Barnas Turlag og si nærmiljøsatsing rundt tusenårsskiftet. Stavanger Turistforening var ei drivkraft bak "52 hverdagsturer i Stavanger» (Stavanger Turistforening, 2012), opna i 2012, og seinare t.d. Trondhjems Turistforening bak Midtby-runden i Trondheim; båe i tett samarbeid med kommunane. Her hadde ein løyst på den ganske skarpe kvalitets-lina mellom det grå og det grøne - for desse (tur-)vegane knytte i hop både det grå, det grøne og det blå. Og her skil ikkje den praktiske bruken mellom tur og transport - og båe delar er like viktig for folkehelsa. Behovet for kommunal samordning mellom friluftsliv, transport, folkehelse og arealplanlegging er poengtert i ein artikkel om 'nærturen' (Skjeggedal et al., 2019).

\section{Det offentlege}

Noreg var tidleg ute med politiske dokument og Stortingsmeldingar om friluftsliv. I 1972-73 kom den såkalla Spesialanalyse om Friluftsliv (Finansdepartementet 1972-73). Alt her vart den stadig gjeldande definisjonen på friluftsliv presentert. ${ }^{1}$ Analysen er eit 40 siders dokument om tilstand, utfordringar og behov for å sikre friluftslivet i samfunnet, særleg

$1 \quad$ Friluftsliv er «Opphald og fysisk aktivitet i naturen, i fritida, med tanke på miljøendring og naturoppleving». I tillegg skal aktiviteten vere ikkje-motorisert. 
i ei tid med sentralisering, omfattande utbygging i kystsona, hyttefelt, modernisering av skogsdrift og ulik arealbruk i utmarka. Sentralt her er kvaliteten på ulike (nær-, langtur-, ferie-)friluftsområde - når det gjeld naturtilstand og variasjon, avstand frå der folk bur, storleik på området, kor påverka/upåverka det er/bør vere, og åtkomst til områda. Analysen er ei tydeleg prioritering av det å sikre område, framfor å opparbeide område. I kapittelet om tilrettelegging legg ein vekt på åtkomst, parkering, ankerpunkt for båt, toalett og tilgang på drikkevatn (+ vedlikehald og vakthald), og tiltak for dei rørslehemma, men ikkje eitt ord om stien. Også den gong gjekk me nok mest på stiar, men kanskje dette var så sjølvsagt at det ikkje vart påtenkt og nemnt?

Statens Friluftsråd (SF) slo alt i 1968 (s. 7) fast at «turområder bør helst ligge innenfor gangavstand fra boligområder», og der «må det opparbeides stier og løyper som gir alternative turvalg og muliggjør god utnytting av områdets naturgitte kapasitet». Denne rapporten var svar på ei bestilling frå Kommunal- og arbeidsdepartementet (KAD) i 1965 om å «utarbeide et forslag om disponering av grunn til friluftsformål». Både SF-rapporten og Spesialanalysen hadde eit tydeleg område-fokus, og bestillinga frå KAD var forankra i frykta for at gode friluftsareal blir mangelvare, særleg by- og tettstadsnært og langs kysten - pga. nedbygging. Behovet var rekna størst på Austlandet og den sørlege kystlina, men SF skulle både vurdere behovet for friluftsområde og lage eit «forslag om hvilke områder som for fremtiden bør sikres for friluftsformål». Vurdert med 2020-briller: Ei radikal bestilling, men også logisk i høve til den politiske uroa på 1960-talet. Det var t.d. i 1965 at byggeforbod i 100-metersbeltet vart innført. ${ }^{2}$ Då hadde det lenge vore protestar mot den omfattande nedbygginga av strandsona. Oslofjorden friluftsråd vart oppretta alt i 1933, nettopp for å demme opp mot nedbygginga. Behovet for friluftslivslova frå 1957 var også i stor grad knytt til denne utviklinga. For det hjelper lite med allemannsrett i utmarka dersom utmarka forsvinn. Alt for 50 år sidan må ein hatt lite tiltru til friluftslivet sitt gjennomslag som samfunnsinteresse i ei prioritering mellom friluftsliv og utbygging. Ein må ha frykta at sjølve utmarka forsvinn i pressområda, særleg langs kysten og by- og tettstadnært, sidan

2 Mellombels strandlov 1965, seinare permanent strandlov i 1971, og så i plan- og bygningslova i 1989. 
desse også er så viktige for friluftslivet. Den frykta er like reell i dag. Når klarar ein så stoppe utbygging av nærskogen med friluftsliv og folkehelse som motargument? Eg påstår: Nærskogar i dalbotn i Gudbrandsdalen (der eg bur) er den mest truga naturtypen i dalføret - kva har du å stille opp mot framføring av ny E6 eller etableringa av nytt næringsareal? Nærskogar er friluftsområde, men endå meir er dei næringsareal på vent for ny utvikling og nedbygging - om dei ikkje vert friluftsprioritert gjennom lokal planlegging eller statleg sikra til friluftsformål.

\section{Sti og tiltak - i Noreg og Sverige}

Turgåarar flest fylgjer altså stiar og turruter, både i nærmiljø og på langturar (Gundersen et al., 2015). Offisielle turruter skal vere merkte, t.d. DNT-ruter, gjerne med mura vardar (i snaufjellet) og så ein raudmåla $\mathrm{T}$ på varden (som ein signatur), på ein stein eller på treleggen - i fjellet. I skogen og ved kysten skal ein bruke blå farge. Andre som merkjer turruter, skal ikkje bruke ' $T$ ', men eit merke i same fargekodane. I 2019 kom ein revidert versjon av Merkehåndboka, som presenterer kva lover og reglar som gjeld, og prinsippa for merking (DNT et al., 2019). Men boka er langt meir enn det. Ho er ein full gjennomgang av arbeidet med å etablere nye turløyper - frå planlegging til gjennomføring, fram til innmelding av ruta til Kartverket. Dette siste er eit krav. Her er også nyttige definisjonar av ulike ferdselsårer: «Sti er et tydelig, smalt og sammenhengede tråkk i terrenget, som har oppstått gjennom bruk eller aktiv tilrettelegging.» Denne er det lett å vere einig i. Vidare kjem Opparbeidd sti (fast toppdekke, lett framkomeleg), Turveg (samanhengande ferdselsåre med jamn og fast toppdekke i minst 1,2 m breidde) og Led (ferdselsåre på vatn og over bre). Ei nyttig fire-deling som bør aktiverast $i$ alt arbeid med ferdselsårer - meiner eg.

Det er sjølvsagt ein lang tradisjon for (lokal og ueinsarta) merking av stiar og turruter i landet. For kvar ny utgåve av Merkehåndboka har ein nærma seg både ein meir samordna og standardisert mal, og utan å hamne i for rigide og teoretiske føringar - slik det ser ut for meg. DNT (stifta i 1868) held fast på si ganske enkle, årlege ny-merking av vinterløyper, med (lauvtre-)kvistar eller bambus. Også dette er nedfelt i Merkehåndboka. 
Det skal vere maks $30 \mathrm{~m}$ mellom kvistane. Om me går til Sverige, så er merketradisjonen noko meir mekanisert. Her er det ikkje STF (Svenska turistföreningen) som har ansvaret, men Naturvårdsverket. Det er særleg vintermerkinga og felles sommar- og vinterruter som skil seg ut, med ein raudmåla Andreas-kross (liggande X) i toppen av ein permanent (heilårs) merkestolpe - dei kallar symbolet for 'ledstjärnan'. Og stolpane skal stå med mindre enn 40 meters mellomrom (Naturvårdsverket, 2019). Ambisjonen har heile tida vore - i Noreg og i Sverige - å få folk ut i naturen og gjerne til fjells - for å drive friluftsliv. Det var ikkje å lage kommunikasjonsårer over fjellet, frå aust til vest, sør til nord - for slike fanst alt. Men sjølvsagt vart mange gamle fjellruter merkt opp som turruter når det daglege samferdselsbehovet til fots eller med hest var borte.

På slutten av 1980-talet arbeidde eg med eit forskingsprosjekt i Femundsmarka - inntil svenskegrensa (Vistad, 1995). Mange ytra seg om skilnader mellom norsk og svensk sti-forvaltning. Ein svenske sa t.d. at Andreaskrossane var som ein kvalitetssignatur for gode turområde; nordmenn eg møtte, såg meir på dei som forstyrrande og unødige installasjonar i villmarka. Svenskane tydde også lettare til fysiske tiltak i sjølve stibanen, om dei såg det naudsynt. Der stiane kryssa myr og våtlende, bygde Naturvårdsverket gjerne langsgåande bord-gangar (spänger, på svensk) over myra. I siste rettleiaren sin skriv dei om dette viktige naturverntiltaket, men åtvarar samstundes om det kroniske (og kostbare) vedlikehaldsbehovet (Naturvårdsverket, 2019). På norsk side var slike bordgangar sjeldan på den tida, og med mykje opptrakka blaut svartmyr som resultat. Og slik sundtrakka myr vert breiare og breiare - fordi folk systematisk går utanom gjørma. Noreg har no nærma seg Sverige i bruken av bordgangar. Og det er fagleg semje om at visse fysiske tiltak i sjølve stibanen (som t.d. bordgangar over myr og blauthol) ofte er beste tiltaket for å redusere slitasjen - men avhengig av naturtypen (Hagen et al., 2019). I Noreg såg ein lenge på dette som (unødig?) service for friluftslivet, men i dag er det mest rekna som eit naturvern-tiltak. Men grunnen til at det er slitasjedempande, er jo fordi folk ikkje vil bli våte eller gjørmete på beina, difor går dei på bordgangen - service-funksjonen utløyser ein vernegevinst. I 2016 vart det gjort ei brukarundersøking i Femundsmarka, og ein svensk gjest skreiv inn ei befaling til forvaltninga på spørjeskjemaet: «Spånga, 
för fan!» (Nasjonalparkforvaltar Thyrum, pers. medd.). Og truleg kunne også ein norsk gjest ha uttalt seg slik i dag. Å legge bordgangar i stien over myra møter no stor forståing i norsk nasjonalparkforvaltning og blir meir og meir vanleg. Kanskje dette er i ferd med å bli den nye norske normalen?

\section{Stien som trivsel og stien som funksjon}

Naturtypen i norske nærmiljø er i hovudsak skog - og ofte barskog. Altså går stiane for nærturen mest i skog. Kva kjenneteiknar ein triveleg sti og eit triveleg skogmiljø? Sjølvsagt avhengig av kven ein spør, men det er (eller det var?) også dominerande mønster. Aasetre spurde om føretrekte miljøkvalitetar blant turgåarar i Oslo og Skien alt tidleg på 1990-talet, og det å "gå på en enkel skogsti» kom klart best ut; omlag 70 \% sa det var svært positivt (Aasetre, 1995). Seinare vart temaet studert vha. 15 foto av ulik infrastruktur i ulike skogmiljø, som gjekk til eit tilfeldig utval vaksne innbyggarar på Austlandet og i Trøndelag (Gundersen \& Vistad, 2016). Det biletet som var mest populært (snitt på 5,63 av maks. 7), såg slik ut (figur 2):

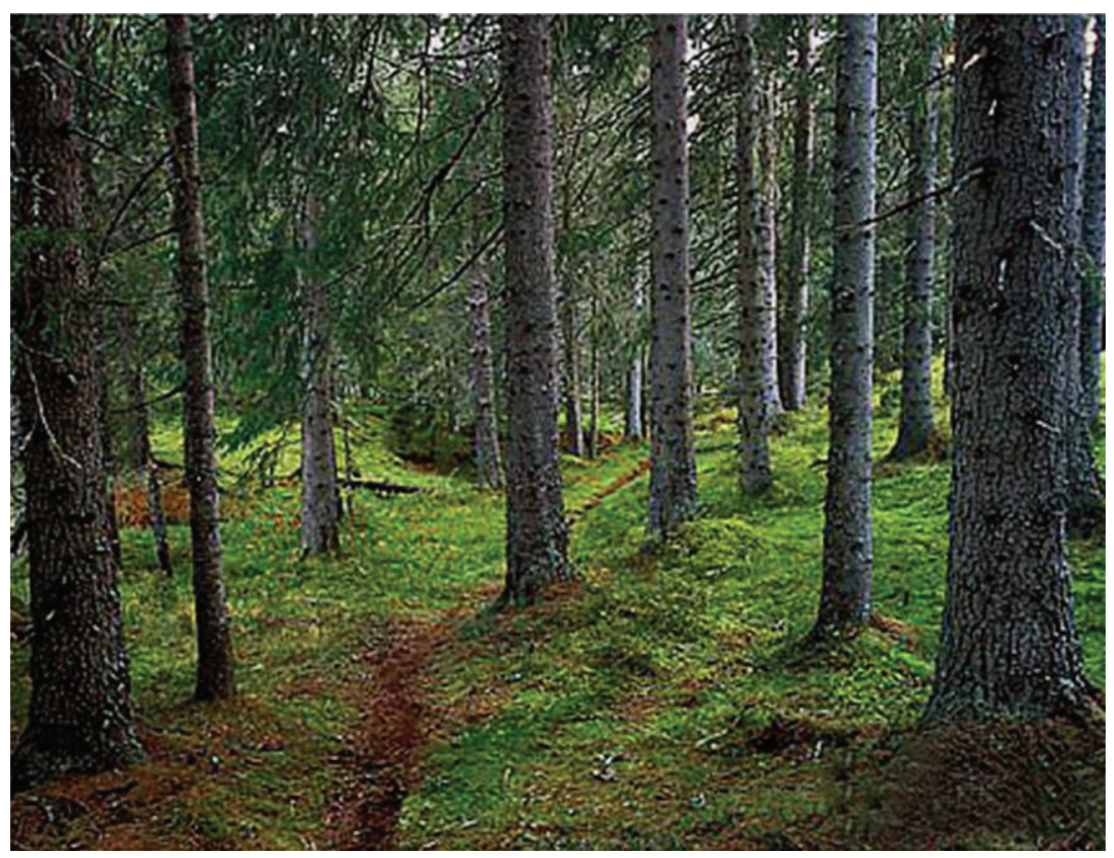

Figur 2. Det mest føretrekte sti- og skogmiljøet (foto: Vegard Gundersen). 
Den enkle og smale trakka stien i ein ganske open og godt vaksen granskog, med grøn skogbotn er favoritten. Inga tilrettelegging å sjå her. Blant dei som kom dårlegast ut, var desse to (figur 3):
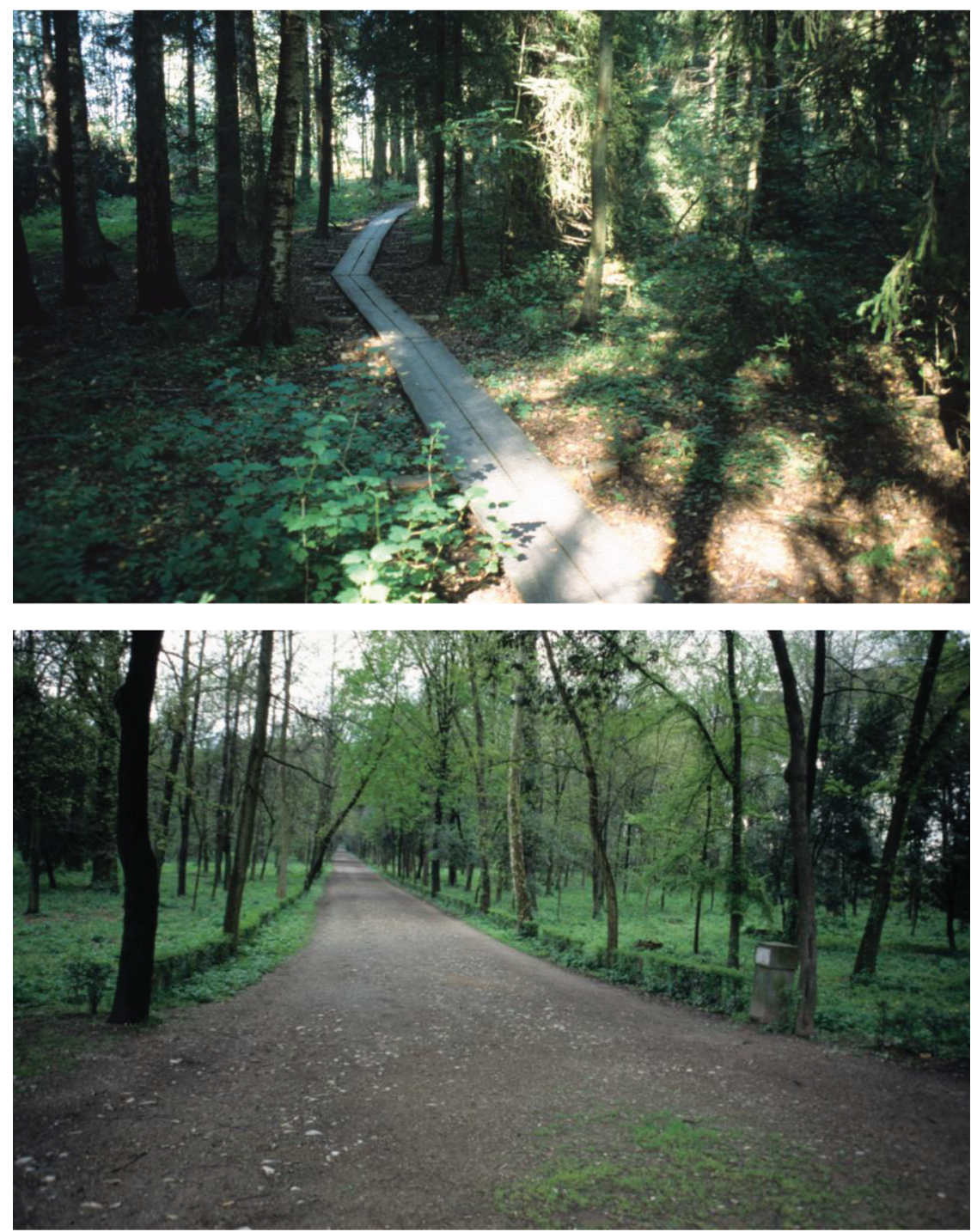

Figur 3. Dei to minst føretrekte sti/turveg- og skogmiljøa (foto: Vegard Gundersen).

I det fyrste ser me ein tettare skog, med lite vegetasjon i skogbotn og ein bordgang til å gå på, sikkert fordi skogbotn er fuktig og lett blir gjørmete og opptrakka av ferdsel (snittskåre 3,63). Slik plankelegging er, som sagt, eit 
vanleg tiltak for å skjerme rå mark mot slitasje. Det er mykje brukt i verneområde. Miljøet i det andre biletet liknar meir på ein park eller ein allé, med brei, rettlina og oppgrusa vegbane (snittskåre 3,78). Båe har tydeleg preg av tiltak og opparbeiding. Me veit jo ikkje kva som slår mest positivt/negativt ut på preferansen - infrastrukturen eller skogmiljøet. Men samspelet sti-miljø er jo udiskutabelt; å splitte dei to blir mest teoretisk, så lenge me snakkar om trivsel og oppleving. Bischoff har kalla avhandlinga si «Mellom meg og det andre finns det stier» - altså stien som bindeledd til 'miljøet' rundt (Bischoff, 2012). Ho konkluderer med at «tilretteleggingen av turstier har en grunnleggende betydning for menneskers opplevelser og forståelse av naturen. Stien utgjør i seg selv en fortolkning av landskapet, og den gir tydelige føringer for turgåerens fortolkninger av det samme landskapet». Men når stien blir verkemiddel for å nå viktige samfunnsmål som naturvern eller folkehelse, når visse prioriterte stifunksjonar trumfar individuell trivsel, så stiller det seg fort annleis. Kor langt må ein akseptere at det kollektive overstyrer, eller overser, individuell trivsel og meir «sjølvsagte» fellesgode? I den same skog-sti-preferanse-artikkelen viser me nemleg også teljardata på kva type stiar / turvegar som blir mest brukt (Gundersen \& Vistad, 2015). Og funna er som ein motsats til preferansen, men på eit logisk og forventa vis. Dei bynære og lett tilgjengelege stiane, som er breie, med plass til både hjul og fot, og har kapasitet til mykje folk, er sjølvsagt dei mest brukte. Slik sett har stiforvaltninga tilpassa seg det lokale (mengde-)behovet - og med folkehelse i tankane er dette rein logikk. Den mest føretrekte (og smale, trakka) stien har liten kapasitet og er dårleg tilpassa farkostar med hjul (med unntak av dyktige stisyklistar). Sjølvsagt treng me universelt utforma turvegar, og særleg der det bur mykje folk.

Så må kanskje trivselssøkjaren 'langt nord i skogen’ for å finne god-stien sin, eller trakke seg sin eigen? Men poenget er ikkje berre turgåarens trivsel; eg starta denne artikkelen med meg sjølv som liten, den gong eg leika i heimeskogen og var lite avhengig av stien - og lite avhengig av dei vaksne. På 8o-talet fekk eg eigne ungar, og familien var på tur i skogen. Å fylgje ein enkel, trakka sti var stas for ungane, å gå på grusveg var kjedeleg. Og sjølvsagt var det det; grusvegen baud ikkje ein unge noko anna enn grus. Stien derimot baud på trerøter å hoppe over, 'knerten-pinnar' å ta med heim, kvilesteinar, ein sving gjennom ei skjørtegran, over ein kneik, vasse ein 
siklebekk - då blir tur å likne med leik - sjå også Skar et al., (2016). Eg vart oppglødd og skisserte prosjektideen: «Jeg gikk en tur på stien - Om stien som middel og tilstand», inspirert av eigne ungar, ein tidleg NINA-rapport som sa at turgåarar føretrekkjer ein enkel skogsti (Aasetre, 1995) - og av Christian Norberg-Schulz (1991, s. 22: «Hvis vi vil, kan vi følge stien ... Den har ikke noe mål, slik som veien, men er en tilstand som lar oss glemme hvor vi kommer fra og hvor vi skal»). Det kom ikkje til eit prosjekt, men poenget er dette: Eg har mine tvil om den breie, grusa turvegen kan vekkje naturinteresse hjå ungar. Den enkle trakka stien (og skogen!) trengst, også der folk bur! Dette har Bischoff fått godt fram i doktorgraden sin, og i fleire av sine essay om stien før denne (Bischoff, 2012; 2006).

\section{Folkehelse}

«Det overordnede målet med Turskiltprosjektet har vort å fremme folkehelse ved å få flere folk ut på tur der de bor og oppholder seg, gjennom informasjon, skilting og merking. Det har også vert et delmål å bidra til økt og trygg friluftsferdsel i folks nærmiljø» (Gjensidigestiftelsen, 2019). Og NINA har testa hovudhypotesen for prosjektet, nemleg at skilting og merking av eksisterande turruter (som var premissen for turskiltprosjektet) får fleire ut på tur (Vistad et al., 2018). Og hypotesen stemmer! Noko av grunnen er at skilting/merking får folk til kjenne seg trygge på kvar dei er, kvar stien går og at dei trygt finn heim att. Ivar Aasen-tilstanden (Kvar i vide Verdi er Vegen til Vinje?) kan melde seg også i eige heimemiljø - om ein er nyinnflytt eller utrygg i nærskogen. I løpet av 5-6 år vart $37609 \mathrm{~km}$ turruter merkt og 70961 turskilt sett opp - ein nasjonal dugnad (nær 106000 dugnadstimar) hjelpt fram av 91,2 millionar kroner frå fylkeskommunane og Gjensidigestiftelsen. Og arbeidet hadde fagleg stønad, styring og rettleiing frå organisasjonane Norsk Friluftsliv, Friluftsrådenes Landsforbund og Den norske turistforening. Tal frå Helsedirektoratet (Hansen et al., 2015) viser at berre kvar tredje vaksne i landet når minstemålet for fysisk aktivitet i veka (som er 150 minutt moderat aktivitet - t.d. det å gå tur). Og friluftsfolket har truleg rett $\mathrm{i}$ at få helsetiltak er billigare enn å stimulere folk ut på tur. Og om ein dessutan lykkast, at stimuleringa får folk ut, så er vel samfunnsøkonomien udiskutabel? 


\section{Friluftsliv og naturforvaltning}

Eg har forska på naturbruk og utmark meir enn ein mannsalder. Mykje av innsatsen har retta seg mot friluftsliv og offentleg naturforvaltning - ikkje minst i fjellet. Nærmiljøet kom seinare. Og kanskje vart flest prosjekt knytt til fjellet, fordi det moderne (og «sær-norske») friluftslivet vakna i den nasjonalromantiske norske fjellheimen?3 Og det moderne naturvernet og nasjonalparkane like så: Der tek fyrste (og andre) kapittel for seg fjellet, men ikkje før hundre år seinare. Dei fyrste offentlege utgreiingane om det 'klassiske naturvernet' kom på 1960-talet. ${ }^{4}$ Også her lurar nasjonalromantikken. I naturvernlova av 1970 var det ikkje økologi og naturmangfald som skulle gje oss nasjonalparkar, men «å bevare større urørte eller $i$ det vesentlige urørte eller egenartede eller vakre naturområder ... på statens grunn ...» (\$3), ikkje minst av vitskaplege grunnar. Kanskje tenkte ein på desse som referanseområde? Og allemannsretten skulle gjelde: Ferdsel utan motor var lovleg, men friluftsliv var ikkje ein del av verneformålet. Ein kunne uansett vere trygg for friluftslivet. Desse områda var alt i bruk og skulle brukast vidare - det var berre spørsmål om måten. Områda var altså ikkje urørte, men naturverninspektør Kristen Krogh og hans samtidige og medansvarlege gav ikkje rom for bilvegar, private hytter og moderne konstruksjonar innanfor vernegrensene (Naturvernrådet, 1964). Men t.d. gamle ferdselsårer, steinbruer, støylar, fangstgroper, fiske- og tilsynsbuer vart nok meir sett som kulturminne enn som påverknad. DNT hadde alt sine løyper og hytter i fleire av desse fjella. Den gong var dette først og fremst byfolkets friluftsliv, medan andre fjell var mest merkte av husdyr, hausting og fangst, eller om ein vil, bygdefolkets brukshistorie. Naturvernlova slo fast at nasjonalparkar i prinsippet skulle leggast på statsallmenning, og der galdt allmenningsrettar forankra i fjellova (frå 1920), og med røter tilbake til mellomalderen, Magnus Lagabøtes landslov (1274) og dei endå eldre landskapslovene (Stang, 2004). Seinare kom fjellova av 1975, som enno står ved lag, men nyleg vart det lagt fram ein NOU (2018) om ei ny fjellov. Sjølvsagt måtte

3 Jf. stiftinga av DNT i 1868.

4 Me kunne også starta før, men forhistoria blir for lang. Rondane var fyrste norske nasjonalparken i 1962. 
ferdsel aksepterast, men oftast avgrensa til den som var forankra i allemannsrettane og friluftslova frå 1957.

Stien var viktig for nær sagt all fjellbruk og difor også viktig i naturforvaltninga - som inngang til å forvalte bruken og brukarane, ved behov (sjå t.d. Kling, 2019). Å forvalte natur er jo mest å forvalte folk! Men verneideologien endra og utvikla seg, og det 'urørte' og særleg det 'vakre' er no meir borte - formelt sett. I 2009 fekk me den 'moderne naturvernlova', naturmangfaldlova. Der heiter det i $\$$ 35: «Som nasjonalpark kan vernes større naturområder som inneholder saregne eller representative økosystemer eller landskap og som er uten tyngre naturinngrep. I nasjonalparker skal ingen varig påvirkning av naturmiljø eller kulturminner finne sted, med mindre slik påvirkning er en forutsetning for å ivareta verneformålet. Forskriften skal verne landskapet med planter, dyr, geologiske forekomster og kulturminner mot utbygging, anlegg, forurensning og annen aktivitet som kan skade formålet med vernet, og sikre en uforstyrret opplevelse av naturen. Ferdsel til fots i samsvar med friluftslovens regler er tillatt.»

Og nasjonalparkane har blitt større - ikkje minst fordi det vart viktigare å verne natur mot ny utbygging enn å hegne om små 'villmarksområde’ der det knapt var merke etter øksehogg. Dei ulike forslags- og vernefasane i Femundsmarka kan illustrere dette Det gjekk frå ein liten 'urørt' trekant mellom Grøtåa, Røa og riksgrensa («som lenge har vort betraktet som fredet» (Naturvernrådet, 1964), rett utanfor Circumferensen - Røros Kobberverks privilegieområde frå 1646), til det utvida for-

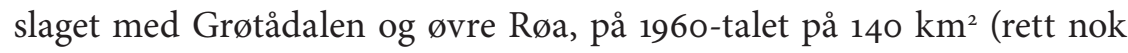
med hogstspor!), via fredinga i 1971 på $345 \mathrm{~km}^{2}$, til siste utvidinga i 2003 til $573 \mathrm{~km}^{2}$ som omfattar det meste mellom Femunden og svenskegrensa, mellom Feragen-Viglen i nord og Elgå-Valdalen i sør. Og her i sør kom altså kravet: 'Spånga, för fan!' i 2016. Om svensken i 2016 helst ville gå tørrskodd, eller hadde omtanke for myra, veit me ikkje. Men poenget er at 'spänger' er eit viktig verkemiddel for å ta vare på naturen, og då kan ein også kompromisse med prinsippet mot fysiske tiltak: «I nasjonalparker skal ingen varig påvirkning av naturmiljø eller kulturminner finne sted, med mindre slik påvirkning er en forutsetning for å ivareta verneformålet» (sjå ovanfor). 
I fleire år no har NINA arbeidd med å utvikle ein metodikk for vurdere kor sårbare ferdselslokalitetar i ulike naturtypar er for påverknad frå ferdsel, og laga ei handbok (Hagen et al., 2019). I denne føreslår me også tiltak for å stoppe eller redusere uønskt påverknad. For å ikkje uroe dyreliv er tiltaket gjerne å omdirigere folk vekk frå det me kallar den 'sensitive eininga' (t.d. hekkeområde, beiteområde), t.d. å legge om stien. Sjølv om allemannsretten gjeld, så har ein høve til å forby ferdsel i ein nasjonalpark dersom viktige naturkvalitetar er trua. Dette er visstnok berre gjort ein gong (for å skjerme eit kartfesta rein-kalvingsområde på Hardangervidda, for perioden 25. april til 31. mai) - og det ferdselsforbodet er seinare oppheva. ${ }^{5}$ Det sit altså langt inne å «tukle med» ferdselsretten. For å redusere slitasje og erosjon på bakke og vegetasjon er tiltaket ofte å forsterke den 'sensitive eininga' (t.d. myr, blauthol), dvs. sjølve stibanen - med steinsetjing eller plankelegging som det vanlegaste. Men har me no kome i ein fase der stiforsterkings-tiltak skjer på autopilot i norsk nasjonalparkforvaltning? Den same paragrafen $(\$ 35)$ seier at «Ferdsel til fots $i$ samsvar med friluftslovens regler er tillatt». Dette er jamgodt med å seie at ein viss påverknad må ein akseptere, og det å legge bordgangar eller stein i stien er også ein påverknad, som kanskje ikkje er spesielt attraktiv, og som attpåtil krev vedlikehald. I Sverige åtvarar som sagt Naturvårdsverket mot den store kostnaden og vedlikehaldsbehovet ved omfattande stokklegging, og dei har lang erfaring (Naturvårdsverket, 2019). Ein amerikansk forvaltningsmodell har det treffande namnet LAC (Limits of acceptable change), sjå Stankey et al. (1985). Kjernespørsmålet er kor mykje av ulik påverknad og endring me vil tole, t.d. frå uunngåeleg trakk, før me set i verk tiltak? Når naturforholda ligg til rette, er det gjerne betre å legge om stien - inn på meir robust mark. Om det blir gjort godt, så er tiltaket både attraktivt og vedlikehaldsfritt. Temaet 'påverknad og (mot-)tiltak' er særleg aktuelt no når alle store verneområde skal lage sin eigen besøksstrategi, utan å svekke vernekvalitetane.

5 Sjå Forskrift for Hardangervidda nasjonalpark av 6. juni 1997 (4.5.1, pkt. c), jamført med dagens forskrift. 


\section{Stein}

I dag gjev vel 'steinsette stiar' mest assosiasjon til sherpastiar - altså stiar bygde eller restaurerte av sherpaer, i sherpatradisjon. Om eigna lokal stein finst, så brukar dei den, og dei arbeider i hovudsak med handmakt og spett. Når steinarbeidet er godt utført, trengst det lite vedlikehald. Ofte er desse stiane kalla 'sherpatrapper', fordi mange av dei er nettopp det: steintrapper. Stien opp frå Gjendesheim mot Besseggen var blant dei fyrste (frå $2005 \mathrm{og}$ framover) som fekk trappetrin og steinsetjing. Formålet var blant anna å kanalisere ferdselen, drenere vekk vatn og redusere erosjon, kombinert med revegetering av 'villstiar', altså eit tydeleg miljøtiltak på ein mykje brukt sti som fører inn i Jotunheimen nasjonalpark. Andre stader blir sherpa-kompetansen brukt til å restaurere gamle murar og vegar. I t.d. Mørkridsdalen landskapsvernområde (inn mot Breheimen nasjonalpark) finst det gamle mura bufarsvegar. Her lyfter forvaltninga fram at restaurering ikkje skal gjerast på sherpa-måten - fordi dette er kulturminne som krev vedlikehald i ein lokal steinbyggar-tradisjon (Evju et al., (2018). Det er sjølvsagt mange slike bygde/mura historiske vegar (stiar) rundt om i landet som krev steinarbeid i ulike tradisjonar. I statsbudsjettet for 2019 kom det ei lita nasjonal «satsing» (1,17 millionar) på Historiske vandreruter - som eit samarbeid mellom DNT og Riksantikvaren.

Hausten 2019 skreiv redaktøren i Fjell og Vidde (medlemsbladet til DNT) at det no er omlag 300 sherpatrapper i Noreg (Kolderup, 2019). Og dette er ikkje berre for restaurering, slitasjedemping og naturvern. Sherpastiar har vorte ein attraksjon i seg sjølv. Og då er ei ny drivkraft på plass, for no vil «alle» ha ein sherpasti. Ofte er dette trapper til eit utsiktspunkt eller ein spesifikk attraksjon. Det er legitimt å trekkje til seg gjester - turistnæring dreiar seg jo om det. Og det er ein mjuk overgang frå friluftsliv til turisme - merk namnet Den norske turistforening. Mang ein distriktskommune har eit håp om at turisme skal gje nye arbeidsplassar og inntekter. Artikkelen til Kolderup hadde overskrifta: «Vi trenger stibyggere», men han åtvarar samstundes mot tendensen av i dag: «... på et tidspunkt er det nok steintrapper i norske fjell». Men altså «stibyggere», det treng me. Argumentet hans er at visse stiar både treng å byggjast og vedlikehaldast (der det er mykje bruk og mykje slitasje) og me manglar profesjonen 'stibyggar'. 
Men stibyggarar (i moderne forstand) har jo vore på banen ei stund (i bokstavleg forstand); kanskje ikkje fordi dei har vore så kvalifiserte, men fordi dei har ønskje og behov. Og av og til byggjer dei faktisk 'banar'. Me snakkar om sti- og terrengsyklistar, og særleg dei som driv med utforsykling. Norsk Organisasjon for Terrengsykling (NOTS) har gjeve ut ei stibyggarhandbok (NOTS, 2017). Den er praktisk retta, med alt frå kontakt med grunneigar og kommune til lineføring i terreng, innfestingsteknikk av plankar og rundstokk, steinsetjing og tørrmuring. Handboka byggjer på opparbeidde handverkserfaringar og kunnskap om god lineføring - både for syklisten og for å dempe vassgraving og erosjon. Ambisjonen til NOTS er ikkje primært å byggje sti for sine syklistar, men å reparere slitasje, forhindre ny slitasje og dempe tendensane til konflikt med andre brukargrupper. NOTS er imot tanken om eigne sykkelstiar. Dei vil at ulike brukargrupper delar dei same stiane, og at allemannsrettane (og -pliktene) skal gjelde (slik dei gjer i dag); «... et ... unntak kan vore fartsfylte utforetapper» (s. 8).

Dei fleste vinterdestinasjonar (alpinanlegg) har i dag eigne sykkelløyper, ikkje minst utforløyper. Dette kan vere inngangen til heilårsdrift og utvida aktivitet, men det krev besøksvolum. Det overordna er at ein kan byggje nye attraksjonar forankra i stien, retta mot bestemte brukargrupper, for å utvikle ny næring, eller forlenge brukssesongen. 'Sykling i naturen' var ein tydeleg vekstaktivitet på 1990- og tidleg 2000-talet (Odden, 2008). Men dette har flata ut. Tal frå SSB (2017) viser at $35 \%$ sykla i naturen i løpet av siste året; det var ein liten nedgang frå 2011 (42\%) og 2014 (40 \%). Ein del av dei som syklar i naturen, syklar på sti eller $i$ terrenget (fyrste gong målt av SSB i 2001). Denne gruppa låg ganske stabilt fram til 2007-målinga (8 \%) og fekk eit solid oppsving til 2011 (25\%). Etter den tid har det igjen vore stabilt; $24 \%$ i 2014 og $23 \%$ i $2017 .{ }^{6}$ I alt syklar $16 \%$ 1-10 turar i året, og dei siste $7 \% 11$ eller fleire turar i 2017.

No skal ei offisiell norsk stibyggarutdanning i gang, som del av det europeiske Erasmus+ programmet (DIRTT - «Developing InterEuropean Resources for Trail builder Training»).? Det er eit samarbeid

\footnotetext{
6 Min eigen analyse av Levekårsundersøkinga 2017, med løyve frå NSD, sidan dette ikkje er publisert av SSB.

7 https://diku.no/aktuelt/verdens-foerste-sykkelsti-utdanning\# 
mellom fleire aktørar, både offentlege og frivillige, m.a. det norske Opplysningskontoret for Terrengsykling. Seks europeiske land er med, og initiativet kjem frå sykkelmiljøet i Europa. Ambisjonen skal også vere å få ei meir berekraftig skjøtting av stiar generelt i landet.

\section{Det offentlege - og politiske føringar}

For 10-20 år sidan snakka og skreiv entusiastar og forskarar om det store helsepotensialet i (særleg) nær-friluftslivet, om kor billig det er å førebyggje og dyrt å reparere, om kor lite det offentlege investerer i friluftslivet, om kor viktig infrastrukturen 'sti' er (Breivik \& Rafoss, 2012), men at stiane og utmarka gror til (sjå figur 1, og Slapgard (2010)). Og me klaga over politikarar som ikkje «forstod» potensialet, og at vår opphaussa allemannsrett kanskje var ei sovepute (Vistad, 2010). Alt dette er stadig gyldig, og likevel har det skjedd vesentlege endringar. Ein nasjonal Handlingsplan og ein Strategi frå 2013 peika ut ei retning og (tilsynelatande?) ein politisk vilje til satsing (Miljøverndepartementet, 2013a; 2013b). I Handlingsplanen for statleg sikring grip ein «tilbake til» (mi tolking!) bodskapen i Spesialanalysen frå 1972-73 (Finansdepartementet 1972-73): Ein vil generere mest mogleg friluftslivsaktivitet og satse sterkare på byar og tettstader. Då må ein av og til kunne sikre nykjel-område ved hjelp av statleg sikring, når nedbygginga har gått for langt og på kostnad av friluftslivet. Ved behov må områda også gjerast attraktive for friluftsliv vha. tilrettelegging. Alle eksisterande statleg sikra friluftslivsområde må oppgraderast med «grunnleggende tilrettelegging». Men kunnskapen om behovet er for liten, og arbeidet med kommunal kartlegging og verdsetjing av friluftslivsområde må fortsetje (Miljødirektoratet, 2013). I Strategien er hovudmålet å auke talet aktive som driv friluftsliv i og ved byar og tettstader. Og ein er tydeleg på ein romsleg definisjon av friluftsliv, av friluft, og av naturoppleving: Grøne omgjevnader i byar og tettstader gjev naturoppleving! Den raud-grøne regjeringa ville sikre friluftsområde (særleg by og tettstadsnært), auke sektorsamarbeidet for å etablere ferdselsårer og løypenett, auke tilskotssatsane (spelemiddel) for turvegar, stiar og løyper, satse på kulturminne som motivasjonsfaktor, og stimulere til skilting og merking. 
Så: ny regjering og ny stortingsmelding om friluftsliv (Meld. St. 18 (2015-2016)). Her er det viktigaste grepet: Å forenkle friluftslivslovverket, la alle ikkje-motoriserte utmarksaktivitetar få eit generelt ferdselsløyve, og "stimulere til tilrettelegging og informasjon som konfliktreduserende tiltak, fremfor strengere reguleringer som avgrenser allemannsretten». Det generelle ferdselsløyvet skulle gjelde kiting, klatring, bruk av rulleski, paragliding og betre høve til å sykle i utmark. Grønstruktursplanar for byar og tettstader er prioritert og generelt verdiskaping basert på naturog kulturarven. Vidare vil ein fjerne restriksjonar på sykling og riding i nasjonalparkar og i landskapsvernområde (på eksisterande vegar, stiar og køyrespor). Same året (2015) vart også Merkevarestrategien for nasjonalparkar lansert og ambisjonen om at kvar nasjonalpark skulle utarbeide sin Besøksstrategi innan 2020 (Miljødirektoratet, 2015).

Regjeringa realiserte no «Handlingsplan for friluftsliv» med ei lang tiltakspakke (Klima og miljødepartementet, 2018). Her vart det lagt opp til at ordninga med sikring av friluftsområde skulle vurderast, for å finne ut om dette «er den mest hensiktsmessige måten for staten til å bidra til ivaretakelse og utvikling av friluftslivsområder». Ordninga er omtalt slik: «En kommune eller et interkommunalt friluftsråd kan søke staten om økonomisk støtte til å sikre området for allmennhetens friluftsliv. Området kan vore eid av det offentlige eller private». ${ }^{8}$ Sikringa kan skje gjennom kjøp eller bruksavtale. Ordninga kom i 1958, og så langt er omlag 2000 område sikra. I Handlingsplanen stilte ein spørsmålet: Skulle ordninga vere som før, endrast eller avviklast? Det vart sett ned ei ekstern arbeidsgruppe med representantar frå kommunar, fylkeskommune, DNT og friluftsråd. Gruppa meinte ordninga måtte vidareførast, og forslaget vart innlemma i statsbudsjettet for 2020 (s. 95). ${ }^{9}$ Handlingsplanen vidarefører elles forslaga om å endre friluftslivslova, og forslaga om utvida bruk av nasjonalparkane (sykkel, hest). Relevant for stiar og ferdselsårer er særleg at ein i 2019 starta eit fleirårig prosjekt med planlegging, opparbeiding, skilting og merking av turstiar i kommunane. Miljødirektoratet har laga ein eigen rettleiar for dette arbeidet (Miljødirektoratet, 2019). Og dette

\footnotetext{
8 www.miljodirektoratet.no/ansvarsomrader/friluftsliv/statlig-sikrede-friluftslivsomrader/

$9 \quad$ KLD Prop. 1 S (2019-2020). Proposisjon til Stortinget. 
sitatet frå Handlingplanen (s. 17) må jo få applaus, i alle fall frå meg: «Tiltaket skal bidra til at den enkleste og vanligste form for friluftsliv, vandring i grøntområder og naturomgivelser, blir lett tilgjengelig for alle grupper $i$ befolkningen. Tiltaket skal legge til rette for å kombinere turgåing og gåing som ledd $i$ daglige gjøremål.» Alle kommunar og fylkeskommunar blir oppmoda om å lage eller revidere sti- og løypeplanar, og ein vil stø opp om «etablering av stier, turløyper og turveger. Turveger skal som utgangspunkt voere tilrettelagt for personer med nedsatt funksjonsevne». Som innleiing til tiltakslista i kapittel 3 har Handlingsplanen denne føringa: «Det er viktig med fysisk tilrettelegging for friluftsliv, men graden av tilrettelegging må differensieres.» Nettopp! Dei økonomiske rammene for KLDs friluftsarbeid har ikkje auka radikalt over åra. Norsk Friluftsliv skriv at omlag 3 \% av KLDs årsbudsjett går til friluftslivsfeltet. ${ }^{10}$ Konkrete og tidsavgrensa tiltaksforslag i budsjetta er oftast fylgt opp økonomisk. Av figur 4 ser vi ei fordelingsendring, som kanskje er politisk forankra og knytt til regjeringsskiftet i 2013/14? Solberg-regjeringa har gjeve mindre til sikring av område (arealtiltak) og meir til aktivitetstiltak og tilrettelegging enn Stoltenberg-regjeringa før.

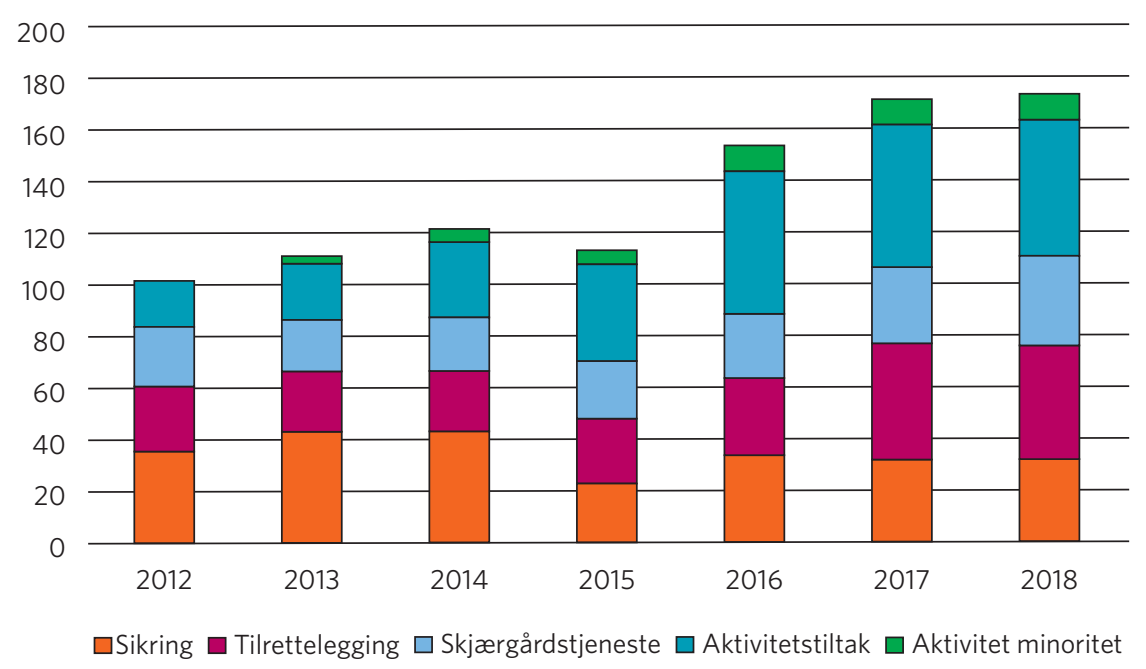

Figur 4. Samanstilling av KLDs budsjett for friluftsliv-området 2012-2018 (Friluftsrådenes Landsforbund, 2019). 
Friluftsorganisasjonane, særleg FL og NF (Norsk Friluftsliv - paraplyorganisasjon for 17 medlemsorganisasjonar) har stått bak, stått på og også vore sterkt involvert med innspel til og ikkje minst gjennomføring av friluftspolitikk - ofte for det enkle og nære friluftslivet. Dei frivillige og deira organisasjonsapparat er på mange måtar avgjerande for å få mykje ut av lite middel, og ikkje minst for å få mykje gjort også utan offentleg stønad (Thorén et al., 2016). Slik har det vore, og slik vil det bli. I 2015 arrangerte DNT og FL (Friluftsrådenes Landsforbund) ein todagars STI-konferanse på Fornebu. Kan stien ha sterk nok appell til ein heil konferanse? Det hadde stien, og 210 deltok. Så kom ein ny STI-konferanse i 2017 på Hamar (med 230) og 2019 i Bergen (med 285). Desse åra vart det omtalte Turskiltprosjektet gjennomført, med organisasjonane som heilt sentrale - både i organisering (DNT) og lokal gjennomføring. Sluttrapporten for dette prosjektet vart lagt fram på siste STI-konferansen (Gjensidigestiftelsen, 2019). Stien er verkeleg «oppdaga»!

\section{Kva så?}

Mykje godt og viktig arbeid er i gang. Medgangstider treng kritiske spørsmål. Kva er dei store mønster, kva er tendensar og trendar, kva er drivkreftene, og er det behov for varsko-rop? Sjølv om ein no kartlegg og verdset friluftsområde i kommunane, så ser eg ein tendens til meir (politisk) merksemd mot bygging av god infrastruktur enn mot sikring av viktige friluftsareal. Ein bryt (heldigvis) ned grensa mellom grøne og grå område, og slik sett mellom nærfriluftsliv og transport, men kan dette også undergrave verdien av å sikre gode, grøne natur- og friluftsområde i nærmiljøet? Me har t.d. aldri greidd å stoppe nedbygginga av strandsona, sjølv om byggeforbodet har eksistert i meir enn 50 år. Då er det vel berre god og eintydig infrastruktur som står att som verkemiddel for å sikre ålmenn tilgang til å ferdast langs (den smale ubygde) strandkanten? (Vistad et al., 2013).

Vi veit at folk flest set mest pris på den enkle trakka stien i vaksen open skog. Men om ein tenkjer funksjon for dei mange, så trengs det gjerne både opparbeidd sti og turveg (jf. Merkehåndboka si inndeling)! Kanskje er det å gjere stien til eit «byggeprosjekt» noko som lyfter den lokale statusen til det turområdet som stien går gjennom? Kanskje det blir vanskelegare 
å ta hundremeterskogen til industriområde eller parkeringsplass når stiane er universelt utforma, merkte og skilta, digitaliserte og tilgjengelege i Kartverkets turstibase, når blauthøla er plankelagt, og når kommunen offisielt har identifisert skogen som eit verdifullt friluftsområde - sjølv om den ikkje er statleg sikra eller plan-regulert som friluftslivsområde?

Og drivkreftene er langt fleire: Om ein vil etablere noko nytt, må gjerne preferansestien vike for funksjonsstien, for å få økonomisk stønad. I folkehelsas namn er nok volum overordna individuell trivsel. Sterke kommersielle krefter pressar på, både næringsaktørar og utstyrsprodusentar. Med referanse til det som skjedde med utstyrs- og aktivitetsspekteret i og rundt alpinbakkane for nokre tiår sidan, ser me no parallellar med sykkel-spekteret og sykling (Odden, 2008). Stadig nyutvikla sykkeltypar gjer det både mogleg, spennande og artig, for den dyktige, å sykle ned bratte stiar - gjerne med merkelapp 'ekstremsport'. Lokale produktutviklarar vil supplere det ekstreme, byggje enklare downhill-trasear (frå vanskegrad svart og raudt, til blått?) slik at fleire vågar seg utfor - då blir det volum, som må til for å forsvare opne heisar i sommarsesongen!?

Det offentlege er sjølvsagt pådrivar for produktutvikling, ikkje minst i såkalla næringssvake strøk. Prosjektet «Naturarven (og kulturarven) som verdiskaper» stimulerer attraksjonsbygging både i og utanfor verneområde. Nasjonale turiststiar skal vere ikoniske turruter (i praksis ofte opparbeidde med stein eller tre), med høge besøkstal, fram til spektakulære naturattraksjonar. Og nasjonalparkane i seg sjølve er gjort til merkevare for reiselivet, og lokale besøksstrategiar vil stimulere tiltak rundt innfallsportar og stiar. Der det er sårbart, tilrår me gjerne stiforsterking med bordgangar eller steinsetjing, og dei same verkemidla tyr me til når bruken blir større enn tenkt. Det er spennande og viktig å fylgje den nye stibyggarutdanninga. Vil den utvikle seg primært til arenabygging for variantar av stisykling, eller vil det også bli arbeidsplassar for nøkternt vedlikehald av eksisterande stiar?

Byggjer eg ein konspirasjonsteori her, eller ser me ein variant av at «det beste er det godes fiende»? Som det står i Handlingsplanen for friluftsliv: «Det er viktig med fysisk tilrettelegging for friluftsliv, men graden av tilrettelegging må differensieres» (KLD, 2018). Eg ville nok også føye til: Mange stader skal me ikkje tilrettelegge, av omsyn til det mangfaldige og enkle friluftslivet forankra i allemannsretten. Klarar me av og til å stå 
imot tiltakspresset, eller er me i ferd med å «byggje» ei ny normal-forståing av 'sti'? Kva blir vårt indre bilete av ein sti - om 10-20 år? Blir det berre område med opparbeidde stiar og turvegar som i framtida vil bli

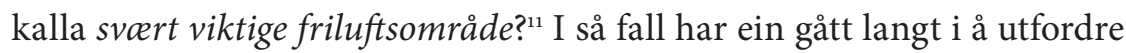
ein heil ferdselskultur, og allemannsretten blir ikkje så viktig lenger? «Ein kan ikkje vite før ein veit», men kanskje er stien inne i eit stort hamskifte.

Til så lenge kan me minne om det som skjedde med snø- og skiløyper, for der er hamskiftet utført. I løpet av 50 år har skituren gått gjennom sine fasar, frå 1960-70-talsnormalen med treski i laus nysnø til dagens skirenn i ‘Snø’-hallen i Lørenskog, med stabil vintertemperatur og god kunstsnø. Dette siste er ikkje den nye normalen. Det er ekstremt og foreløpig unormalt. Som Gudmund Skjeldal skriv om dei ansvarlege: «Eg veit at denne idrettsklubben meiner det beste for ungane, eg har ikkje lyst til å seia eitt vondt ord om dei» (Skjeldal, 2020). Men me treng ikkje sjå til denne ekstremvarianten med ski innomhus: Skiløype-normalen har gått ifrå noko me trakka opp, til noko som er oppkøyrt med maskin, både bortover og nedover. Dette er ikkje å overdrive.

\section{Litteratur}

Bischoff, A. (2006). Fornemmelse for stien. Rapport fra konferansen Forskning $i$ friluft 2005, 108-117.

Bischoff, A. (2012). Mellom meg og det andre finns det stier. En avhandling om stier, mennesker og naturopplevelse [Doktorgradsavhandling]. Universitetet for miljøog biovitenskap.

Breivik, G. \& Rafoss, T. (2012). Fysisk aktivitet; omfang, tilrettelegging og sosial ulikhet en oppdatering og revisjon. Norges Idrettshøgskole \& Høgskolen i Finnmark.

Christensen, A. L. (2002). Den norske landskapet. Om landskap og landskapsforståelse i kulturhistorisk perspektiv. Pax forlag.

Den Norske Turistforening, Innovasjon Norge og Friluftsrådenes Landsforbund. (2019). Merkehåndboka. Tilrettelegging og synliggjøring av turruter.

Evju, M., Eide, N. E., Vistad, O. I. \& Rød-Eriksen, L. (2018). Sårbarhetsvurdering av utvalgte lokaliteter i Breheimen nasjonalpark og Mørkridsdalen landskapsvernområde. Stier i innfallsportene Dumdalen, Hødnevollen og Mørkri (NINA Rapport 1589). Norsk institutt for naturforskning.

11 Sjå dagens kriteriesett i Miljødirektoratet, 2013. 
Friluftsrådenes Landsforbund. (2019). Årsmelding 2018/2019. www.friluftsrad.no Gjensidigestiftelsen. (2019). Turskiltprosjektet 2013-2019 Sluttrapport.

Grepstad, O. (2020). Einar Økland. Allkunne. https://www.allkunne.no/framside/ biografiar/o/einar-okland//111/1325/

Gundersen, V., Mehmetoglu, M., Vistad, O. I. \& Andersen, O. (2015). Linking visitor motivation with attitude towards management restrictions on use in a national park. Journal of Outdoor Recreation and Tourism 9, 77-86.

Gundersen, V. \& Vistad, O. I. (2016). Public opinions and use of various types of trails in boreal forest setting. Forests, 7 (113), 1-18. https://doi.org/10.3390/f7060113

Hagen, D., Eide, N. E., Evju, M., Gundersen, V., Stokke, B., Vistad, O. I., RødEriksen, L., Olsen, S. L. \& Fangel, K. (2019). Håndbok. Sårbarhetsvurdering av ferdselslokaliteter i verneområder, for vegetasjon og dyreliv (NINA Temahefte 73). Norsk institutt for naturforskning.

Hansen, B. H., Anderssen, S. A., Steene-Johannessen, J., Ekelund, U., Nilsen, A. K., Dehli Andersen, I., Dalene, K. E. \& Kolle, E. (2015). Fysisk aktivitet og sedat tid blant voksne og eldre i Norge. Nasjonal kartlegging 2014-2015. Helsedirektoratet.

Klima og miljødepartementet. (2018). Handlingsplan for friluftsliv. Natur som kilde til helse og livskvalitet (T-1564 B).

Kolderup, T. S. (2019). Vi trenger stibyggere. Leder. Fjell og Vidde, 5.

Miljødirektoratet. (2013). Kartlegging og verdsetting av friluftslivsområder (Veileder M98).

Miljødirektoratet. (2015). Veileder for besøksforvaltning i norske verneområder (Veileder M-415).

Miljødirektoratet. (2019). Plan for friluftslivets ferdselsårer (Veileder M-1292).

Miljøverndepartementet. (2013a). Nasjonal handlingsplan for statlig sikring og tilrettelegging av friluftslivsområder (T-1534).

Miljøverndepartementet. (2013b). Nasjonal strategi for et aktivt friluftsliv. En satsing på friluftsliv i hverdagen; 2014-2020 (T-1535).

Naturvernrådet. (1964). Innstilling om landsplan for natur-og nasjonalparker i Norge. Kirke- og undervisningsdepartementet.

Naturvårdsverket. (2019). Vägledning om förvaltning av det statliga ledsystemet $i$ fiällen. www.naturvardsverket.se

Nordberg-Schulz, C. (1991). Minnesjord. Gyldendal.

NOTS (2017). Stibyggerhåndbok. Norsk organisasjon for terrengsykling. Kolofon Forlag. NOU 2018: 11. (2018). Ny fjellov. Landbruks- og matdepartementet.

Odden, A. (2008). Hva skjer med norsk friluftsliv? En studie av utviklingstrekk i norsk friluftsliv 1970-2004 [Doktorgradsavhandling]. Norges teknisk-naturvitenskapelige universitet.

Skar, M., Gundersen, V. \& O’Brien, L. (2016). How to engage children with nature: Why not just let them play? Childrens's Geographies, 14 (5), 527-540. 
Skjeggedal, T., Vistad, O. I. \& Thoren, K. (2019). Planlegging for nærtur og folkehelse. Kart og Plan, 4, 241-257.

Skjeldal, G. (2020, 8. februar). Eit horehus og ein hall med snø. NRK. https://www. nrk.no/ytring/eit-horehus-og-ein-hall-med-sno-1.14888785

Slapgard, S. (2010, august). På attgrodde stiar. Gudbrandsdølen Dagningen, Debatt.

Statistisk Sentralbyrå. (2020). Idrett og friluftsliv, levekårsundersøkelsen. https://www. ssb.no/kultur-og-fritid/statistikker/fritid

Stang, C. (2004). Rettigheter i utmark - i historiske perspektiv. Landbruksforlaget.

Stankey, G. H., Cole, D. N., Lucas, R. C., Petersen, M. E. \& Frissell, S. S. (1985). The limits of acceptable change (LAC) system for wilderness planning (Rapport INT-176). GTR, Intermountain Forest and Range Experiment Station, USDA Forest Service.

Statens Friluftsråd. (1968). Områder for friluftsliv i Norge. 1. Behovet for områder.

Stavanger Turistforening. (2012). Lofta vedet. 52 hverdagsturer i Stavanger.

Steinsland, G. (2020, 24. februar). Veienes historie. Klassekampen.

St. meld. nr. 71 (1972-73). Langtidsprogrammet 1974-1977. Spesialanalyse 6 Friluftsliv. Finansdepartementet.

Svarstad, H. (2010). Why hiking? Rationality and reflexivity within three categories of meaning construction. Journal of Leisure Research, 42(1), 91-110.

Thorén, K. H., Skjeggedal, T. \& Vistad, O. I. (2016). Kommunale planer for idrett og fysisk aktivitet. Om spillemidlenes betydning for å etablere turveier og turstier $i$ normiljøet (NINA Kortrapport 26).

Vistad, O. I. (1995). I skogen og i skolten - ein analyse av friluftsliv, miljøoppleving, påverknad og forvaltning i Femundsmarka, med jamføringar til Rogen og Långfjället [Doktorgradsavhandling]. Universitetet i Trondheim.

Vistad, O. I. (2010, september). Det sjølvsagte friluftslivet. Gudbrandsdølen Dagningen, Debatt.

Vistad, O. I., Tennøy, A., Svarstad, H. \& Andersen, O. (2006). Evaluering av Friluftslivets År 2005 (NINA 170). https://www.norskfriluftsliv.no/wp-content/ uploads/2015/o1/NINA-Rapport-170-Evaluering-av-Friluftslivets-r-2005.pdf

Vistad, O. I., Skår, M., Wold, L. C. \& Mehmetoglu, M. (2013). Balancing public access and privacy in developed coastal zones. Factors influencing attitudes towards potential management options. Journal of Outdoor Recreation and Tourism, 1(3-4), 7-18.

Vaage, O. F. (2015). Fritidsaktiviteter 1997-2014. Barn og voksnes idrettsaktiviteter, friluftsliv og kulturaktiviteter. Resultater fra Levekårsundersøkelsene (Rapporter 2015/25). Statistisk sentralbyrå.

Aasen, I. (1976). Skrifter: Eit uval. Det Norske Samlaget.

Aasetre, J. (1995). Friluftsliv i bynœere skogområder - en undersøkelse blant turgåere i Skien og Oslo. Norsk Institutt for Naturforskning. 


\title{
KAPITTEL 10
}

\section{Har utmarka blitt historie?}

\section{Knut Fageraas}

MiA - Museene i Akershus og Norsk institutt for naturforskning (NINA)

\begin{abstract}
Over the past hundred years we have seen a wide-ranging agricultural land abandonment process and land-use transformation with respect to the outfields of rural areas. In addition, large outfield areas have been protected as nature reserves and national parks, concealing their cultural legacy. Despite a shift in the landscape's status and its diminished importance to rural livelihoods, we have witnessed a broadened interest in the cultural heritage of outlying fields. This is apparent not least in the fact that the historical remains and cultural landscape of outfield areas have come to the forefront of national cultural heritage policy, are targets for tourism initiatives, and have been at the core of local identity struggles. This chapter takes as its point of departure the growing field of heritage politics in present day society through a focus on the many actors' engagement with different aspects of the past in relation to landscape characteristics and historical remains in outfield areas. The aim is to provide insight into ways the past is managed and engaged in certain political, economic and social contexts, as a background to reflect on diverse aspects of cultural heritage, social justice related to its management, and its value for local communities. Cultural heritage policy and practices contribute to the varying uses of outfield areas, affecting ways people perceive the landscape, dwell within it, and despite the potential for conflict of interest - see future opportunities.
\end{abstract}

Keywords: cultural heritage, environmental politics, national parks, outfields

\section{Innledning}

Samfunnet er i endring - og dermed også det fysiske landskapet, så vel som folks oppfatninger om det. Utmarka er et godt eksempel. Nær sagt overalt der det er skog og fjell er det spor etter menneskers utmarksbruk, men bygninger forfaller og landskapet gror igjen, og minner etter tidligere bruk forsvinner. Samtidig har utmarkas kulturminner og kulturmiljøer fått større oppmerksomhet enn før, og blitt en viktig del av samfunnets

Sitering: Fageraas, K. (2021). Har utmarka blitt historie? I F. Flemsæter \& B. E. Flø (Red.), Utmark $i$ endring (Kap. 10 s. 265-283). Cappelen Damm Akademisk. https://doi.org/10.23865/noasp.151.ch10 Lisens: CC BY-NC-ND 4.0 
kulturarv. Det betyr ikke at kulturhistoriske verdier var uten betydning i utmark før, men det har skjedd et skifte, som må ses i lys av en økt interesse for kulturarv i samfunnet mer generelt. Kulturarv er viktig både i nasjonal politikk, for reiseliv og for lokal identitet. «Kulturminner i utmark» var for eksempel en av de tre høyest rangerte temaene i Riksantikvarens Fredningsstrategi mot 2020, hvor kulturminner knyttet til jakt, fangst og fiske, setring og skogbruk, skulle være prioritet (Riksantikvaren [RA], 2015, s. 9-10). Mange av disse kulturminnene kan være ganske unnselige spor etter menneskelig virksomhet. Kontrasten er stor i forhold til hvordan Riksantikvarens fredningspraksis opprinnelig var, med vekt på det som var eldst, mest sjelden, monumentalt og estetisk fint. Det som var oppfattet som høyverdig, var også verneverdig (Christensen, 2011, s. 72).

Dette kapitlet handler om hvordan den økte interessen for kulturarv i samfunnet også har påvirket utmarkas verdi. For også utmarkas kulturarv har fått økt oppmerksomhet. En vesentlig årsak er selvsagt at mange av de fysiske kulturminnene og det kulturpregete landskapet er i ferd med å forsvinne som et resultat av nedlegging av konvensjonell landbruksdrift og endrete bruksmønstre. Det har også noe med vår nostalgi for hvordan ting var før, og personlige tilknytninger til steder og landskap som er viktig for identitet. Men det handler ikke bare om en redningsaksjon for noe gammelt, satt i gang av forfall og kulturlandskap som gror igjen, eller folks sterke bånd til kjente og kjære steder. Engasjement for kulturarv har vært et sterkt voksende fenomen, som omfatter stadig flere ting og måter å minnes og markere fortiden på. Det skal blant annet være en ressurs både for verdiskaping og samfunnsutvikling mer bredt. Kulturarvsforsker Rodney Harrison (2013, s. 68-70, 95) kalte det en kulturarvsboom. Den kjente historikeren og geografen David Lowenthal (1998, s. 3) skrev ved årtusenskiftet at det aldri noen gang har vært så mange som har engasjert seg i så mange forskjellige sider ved fortiden. Det har åpenbart også nådd utmarka. «Heritage is everywhere», skriver kulturarvsforsker Rodney Harrison (2013, s. 1, 6), blant annet med referanse til Lowenthal.

Hva har dette betydd for utmarka? Har avviklingen av utmarksbruken kommet så langt at utmarka snart er historie, eller er kulturarv noe som bidrar til at utmarka får ny verdi? Hvordan kan i så fall 
et kulturarvsperspektiv gi en forståelse for hvordan utmarka er i endring? Dette er spørsmål jeg har vært opptatt av, og som jeg vil forsøke å gi noen svar på her. Formålet med denne artikkelen er å rette søkelys på den endrete statusen som utmarkas kulturarv har fått, og vise noen eksempler på hvordan kulturarv får betydning for forvaltning og bruk av utmarka. For å forstå betydningen av kulturarv i utmark, er det nødvendig å forholde seg til et utvidet kulturarvsbegrep. Det har skjedd en konseptuell endring av begrepet, som både gjenspeiler det at kulturarv også er noe som assosieres til natur - mange kulturminner får verdi i relasjon til landskap og miljø, og at kulturarv favner stor kulturell diversitet, gjennom de mange måtene kulturarv gir mening og verdi for ulike grupper i samfunnet. Det handler om noe så grunnleggende som demokratisering og sosial rettferdighet, hvor alle sosiale gruppers kulturarv er anerkjent. Kulturarv må med andre ord forstås som noe innholdsrikt og variert.

\section{Hvordan kan vi utforske en slik variasjon?}

I min tid som kulturarvsforsker har jeg fătt innsikt i forskjellige aspekter ved den økende interessen for kulturarv. Også utviklingen innenfor kulturarvsforskning har vært markant. Et viktig bidrag har kommet fra en ny forskningsinteresse, for en mer kritisk-refleksiv kulturarvsforskning, som fikk noen definerende bokutgivelser omkring årtusenskiftet, med A Geography of Heritage. Power, Culture and Economy (Graham et al., 2000) og Uses of Heritage (Smith, 2006). Den sistnevnte boken, skrevet av Laurajane Smith, var basert på en diskursteoretisk tilnærming som har hatt avgjørende betydning for den sentrale posisjonen denne forskningsretningen har fått. Kulturarvsforskningen gjennomgikk en diskursiv vending, i likhet med samfunnsforskning generelt. Nå handlet det ikke om forvaltning, bevaring og identifisering av kulturminner, men om hvem som definerer hva som er kulturarv, og hvilken betydning kulturarv har for samfunnet. Forskning på forvaltning kom i søkelyset, ekspertenes vurdering av kulturminners verdi ble satt under lupen, og mer folkelige verdsettinger ble satt i kontrast. Who Needs Experts? titulerte kulturarvsforsker John Schofield sin bok fra 2014, med undertittelen Countermapping Cultural Heritage. En tydelig makt- og konfliktdimensjon var 
skrevet inn i kulturarvsforskningen - og i den kritiske retningen, et aktivistisk, sosialt program for å løfte fram de alternative måtene som kulturarv blir verdsatt på av ulike folk (Association of Critical Heritage Studies [ACHS], 2012).

En viktig inngang til å forske på kulturarv på denne måten ble å studere hvordan kulturarv skrives om og omtales - ikke nødvendigvis med en systematisk diskursteoretisk metodikk, men inspirert av ulike diskursteoretiske tilnærminger. Det har også vært inngangen i en del av min forskning og i det kapitlet jeg skriver her. Sentralt i internasjonal kulturarvsforskning står de internasjonale konvensjonene og chartrene på feltet. I min forskning har først og fremst studier av norske policy- og forvaltningsdokumenter vært sentralt. I tillegg kommer dokumentstudier av fagrapporter og annen relevant litteratur som berører de områdene jeg har studert, samt analyse av relevante mediesaker og debatter i aviser og sosiale medier. Kulturminnedata fra offentlige registre og kartframstillinger har jeg brukt som et utgangspunkt for å sammenlikne helt konkret hva som er offisielt identifisert som kulturminner med hva som er verdsatt lokalt, i bruk og del av lokalkunnskap.

Det diskursive forskningsperspektivet har imidlertid skapt en reaksjon, fordi det ikke på noe godt vis inkluderer de affektive kvalitetene kulturarv har for folk (Fageraas, 2019, s. 30-32; Harrison, 2013, s. 112; Tolia-Kelly et al., 2018). Derfor har nå en god del kulturarvsforskning støttet seg på ny metodologi, med røtter i fenomenologien, som ligger nærmere min fagbakgrunn med utgangspunkt i etnografiske feltarbeid og kulturstudier, hvor kulturarvsverdier slik de erfares står i sentrum. Det dreier seg både om turisters opplevelser, og om kulturarvsverdier som har å gjøre med identitet og som berører folk personlig og emosjonelt. Som etnolog har intervjuer vært det typiske kildematerialet når jeg forsker på folks oppfatninger om kulturarv. Den empirien som ligger til grunn for eksemplene jeg bruker i dette kapitlet, har imidlertid først og fremst vært uformelle samtaler i ulike sammenhenger og observasjoner under befaring og forskningsfeltarbeid. Dette er imidlertid uvurderlige kilder i kvalitativ forskningspraksis, og nødvendig i kombinasjon med dokumentstudier for å få kunnskap om både offisielle og folkelige kulturarvsverdier. 


\section{En inngang til verna utmark}

Kulturarv i grenseland mellom natur og kultur, og kulturminner som ikke nødvendigvis har hatt særlig høy status, har av en eller annen grunn blitt mitt forskningsfelt. Derfor er kulturarv i utmark interessant. Gjennom arbeid med skjøtsels- og kulturminneplaner i verneområder, og forskning på verdensarv og nasjonalparkforvaltning, har jeg fått kunnskap om kulturarv som både er vanskelig å forvalte og som skaper til dels sterk konflikt. I dette kapitlet skal jeg bruke eksempler fra Hardangervidda og Dovrefjell, som kan være illustrerende både for hvordan kulturarv i utmark kan komme i spill når det må prioriteres mellom ulike miljøverdier knyttet til natur og kultur, og hvor forskjellig verdsettingen av denne kulturarven kan være. Nasjonalparker er interessante studieobjekter blant annet fordi de omfattes av mange forskjellige politikkfelt, både natur- og kulturmiljøvern, landbruk, friluftsliv, helse, reiseliv og distrikt. Hardangervidda og Dovrefjell er brukt som eksempler fordi de representerer områder med fortsatt utmarksbruk, og hvor interessemotsetninger mellom bruk og vern på ulike måter har kommet til uttrykk, og slik framhever hvilke kulturarvsverdier som kan komme i spill.

Mange steder i landet har den norske utmarka strukket seg langt innover fjellet, blant annet i områder som i dag har status som verna natur. Selv nasjonalparkene har en brukshistorie og mange kulturhistoriske spor. Mange av dagens verneområder har vært avgjørende for livnæring i bygdesamfunnene rundt, gjennom omfattende, ekstensiv ressursbruk. Noen verneområder er i dag fortsatt viktige for konvensjonelt landbruk. Samtidig legges det til rette for ny bruk. Nasjonalparkene har ikke nødvendigvis skilt seg mye fra øvrige utmarksområder i landet når det gjelder økt turisme og næringsutvikling, som i og rundt nasjonalparker lenge har vært en internasjonal trend (Aas et al., 2003, s. 3, 11). Noen mener at vi ikke engang har ordentlige nasjonalparker i Norge, i betydningen store, urørte naturområder, fordi de nettopp er så sterkt preget av bruk, og fordi beiting og jakt er tillatt i så stor grad, som det ikke er i nasjonalparker i mange andre land. Selv om vern av urørt, eller tilnærmet urørt, natur har vært et hovedmål med etablering av nasjonalparker i Norge, er det samtidig en utbredt erkjennelse at det bare unntaksvis finnes områder i landet 
som er helt urørt av menneskelig virksomhet (Meld. St. 64 (1965-1966); Meld. St. 62 (1991-1992), s. 37).

Vern av utmark er likevel et tegn på at mye av den konvensjonelle ressursbruken og kulturpreget er borte. Isteden har det skjedd en sterk framvekst av næringsmuligheter i form av post-produktiv økonomi gjennom natur- og kulturbasert reiseliv. Riksantikvaren har i samarbeid med Miljødirektoratet hatt en egen satsing for å bedre vernet av kulturminner og skape økt interesse for kulturhistorien i verneområder, nettopp med tanke på at det skal være en ressurs for et slikt reiseliv (Miljødirektoratet [Mdir] \& RA, 2015). Dette kan kanskje virke paradoksalt, fordi det jo dreier seg om områder som er dominert av en forvaltning hvor naturhensyn står i sentrum. Men den offentlige kulturminneforvaltningen har i stadig større grad blitt integrert i en helhetlig ressursforvaltning og et bredere miljøpolitisk felt. Samtidig er fredningslistens tematiske og geografiske representativitet et sentralt politisk mål som Riksantikvaren skal følge opp (Klima- og miljødepartementet [KMD], 2020a, s. 4; Prop. $1 \mathrm{~S}$ (2019-2020), s. 178). Dette er noe av grunnen til at også nasjonalparkenes kulturminner, kulturmiljøer og kulturpregete arter og naturtyper har kommet i søkelyset mer enn før.

\section{Kulturarv som praksis}

Samtidig er ikke kulturarv hva det en gang var. Vi skal ikke mange tiår tilbake før begrepet kulturarv var relativt lite i bruk. I norsk offentlig politikk og forvaltning er fortsatt kulturminner det juridiske begrepet på historiske spor i terrenget og gamle fysiske levninger. Lenge var begrepet kulturarv basert på en juridisk tenkning om historiske monumenter, bygninger og steder ut fra et eiendomsrettslig perspektiv (Logan et al., 2016, s. 4; Ronström, 2007, s. 74, 76). Fortsatt ligger det i begrepet at det dreier seg om en arv av kultur. Det brukes som en samlebetegnelse for både materiell og immateriell kultur, og ble særlig utbredt etter etableringen av UNESCOs verdensarvkonvensjon fra 1972 og utviklingen av verdensarvlisten (Davison, 2008, s. 31-32; se også Harrison, 2013, s. 88-89). Internasjonalt, i engelskspråklig sammenheng, blir det dessuten ofte bare brukt heritage, som kan bety både natur- og kulturarv. 
Som en slags arv i en eller annen form, kan begrepet bli assosiert med noe materielt og konkret, men kulturarv kan ikke forstås uten en immateriell dimensjon. I den kritisk-refleksive retningen innenfor kulturarvsforskning, handler kulturarv om bruk av fortiden i ulike sosiale, økonomiske og politiske kontekster. Kulturarv er sporene etter fortiden som mennesker velger å verdsette i nåtiden. Det handler om å skape mening $i$ og for sin samtid (Graham et al., 2000; Smith, 2006). Derfor er kulturarv også alltid i forandring, relativ og situert i ulike kontekster. Det handler med andre ord ikke bare om noe fortidig, selv om det også gjør det. Kulturarv handler om noe relatert til fortiden, som verdsettes og gis mening i nåtiden, og med tanke på bevaring for framtiden. Kulturarv kan defineres som performativ praksis, som produseres og utøves gjennom forskjellige måter å identifisere, markere og minnes noe som har med fortiden å gjøre (Smith, 2006, s. 3).

Innenfor kritisk kulturarvsforskning framstår kulturarv, kanskje mer enn noe annet, likevel som politiske handlinger (ACHS, 2012). Til tross for en demokratisk fundert politikk for å sikre mangfold, involvering og legitimitet, vil det eksistere en offisiell og ekspertbasert forståelse av hva kulturarv er og bør være, og som framholdes av samfunnsinstitusjoner med myndighet (Smith, 2006). Riksantikvaren er en slik typisk autoritativ myndighet på kulturarvsfeltet, og blir en toneangivende aktør for å definere og forsvare hva som har mest verdi. I samfunnet vil det imidlertid finnes andre kulturarvsforståelser med utspring i ulike sosiale gruppers behov for å skape mening og tilhørighet (Smith, 2006). Da handler det isteden om et identitetspolitisk aspekt. Vi kan derfor snakke om forskjellige former for kulturarvspraksiser. Kulturarv forstås og verdsettes på ulikt vis, og i så måte trenger vi et kulturarvsbegrep som kan romme en slik diversitet. Samtidig handler det også om natur.

\section{Kulturarv som miljøressurs}

Norsk kulturmiljøforvaltning er underlagt miljøpolitikken, et politikkfelt som fikk økt betydning og ble uavhengig av sektortilknytning fra 1960årene, manifestert formelt og reelt da Miljøverndepartementet ble opprettet i 1972. Ressurs var et nøkkelord, og det nye departementet skulle 
arbeide for å finne «best mulig balanse mellom utnytting av ressurser for økonomisk vekst, og vern om naturressursene» (KMD, 202ob). Kulturminner var helt fra starten en del av det nye departementets ansvarsfelt, og ble stadig tettere integrert i denne ressursforvaltningen. Rapporten fra FNs World Commission on Environment and Development (1987), Our Common Future, i Norge kjent som Brundtland-rapporten, fikk særlig stor betydning for tenkningen om en helhetlig ressursforvaltning hvor natur og kultur ble sett i sammenheng. Det påvirket også forståelsen av kulturminners verdier, og dermed kulturminnefeltets arbeid (Molaug et al., 2004, s. 9). Kulturminnevern ble koblet til natur og miljø, og kulturlandskap og kulturmiljø ble helt sentrale begreper.

Brundtland-rapporten bidro samtidig til ny tenkning om miljøgoder som ressurser, ved å sette bærekraftig utvikling på dagsorden. Vern og bruk skulle kunne forenes gjennom et bærekraftperspektiv som ble koblet til utvikling, og det ble en klarere kobling mellom miljøpolitikk og nærings- og distriktspolitikken (Nærings- og handelsdepartementet, 2012). Dette utviklings- og bærekraftperspektivet kom til uttrykk på kulturminnefeltet ved at politikken la vekt på at kulturminner ikke bare skulle vernes, men brukes, og også skape verdier gjennom et verdiskapingsparadigme, som fortsatt ligger til grunn for mye av politikken på feltet. Kulturminner er mer enn en kilde til historien, og kan brukes til næring og verdiskaping som del av en miljøressursøkonomi som skal bidra til samfunnsutvikling.

På begynnelsen av 2000-tallet ønsket Stortinget satsing på næringsutvikling knyttet til utmarka og fjellområdene. Den såkalte «Fjellteksten» fra 2003 (St.prp. nr. 65 (2002-2003), s. 140-153) var et svar på dette, som representerte et politikkskifte i forvaltningen av de norske nasjonalparkene ved at det ble åpnet for større grad av lokal verdiskaping og kommersiell reiselivsvirksomhet (Lundberg et al., 2013, s. 3). Målet var bærekraftig utvikling gjennom økt bruk, som også skulle være et middel til økt legitimitet til naturvernet, etter mange år med konflikt knyttet til gjennomføringen av nasjonalparkplanene (Lundberg et al., 2013, s. 3). Det samme kan sies om kulturminnevernet, som gjennom parolen vern gjennom bruk både har søkt å få økt legitimitet, sikre bevaring og bidra til verdiskaping. Vi finner dette også i Riksantikvarens og Miljødirektoratets 
satsing på kulturminner i verneområdene, som er satt i gang for å sikre vern gjennom at «kulturminnene kan knyttes til videreføring av dagens bruk og danne grunnlag for ny verdiskaping og endret bruk» (Mdir \& RA, 2015, s. 23).

\section{Mellom vern og bruk}

Hardangervidda er et interessant eksempel på en nasjonalpark med både konvensjonell og ny bruk, samtidig som dette høyfjellsområdet er svært rikt på kulturminner og bevisstheten om kulturarv er sentralt. I tillegg skiller den seg fra andre nasjonalparker på flere vis, som gjør at noen aspekter ved forvaltning, verdsetting og bruk - som jeg fokuserer på - blir tydeliggjort. Hardangervidda nasjonalpark betegnes både som villmark, utmark og ideell for friluftsliv. Da nasjonalparken ble etablert i 1981, var det svært kontroversielt, og ble gjort på særskilte vilkår fordi over halvparten av arealet var privat eiendom, og på grunn av de mange bruksrettighetene som fortsatt ble holdt i hevd. I den siste forvaltningsplanen som er laget for Hardangervidda nasjonalpark (Fylkesmannen i Hordaland, Buskerud og Telemark [FHBT], 2011, s. 4) er det konstatert at de lokale bruksinteressene samlet sett er langt større enn for noen annen nasjonalpark i landet. Der vises det også til at det er et av landets mest brukte fjellområder til friluftsliv, noe som har dannet grunnlag for en omfattende turistnæring med stor betydning for bosetting og sysselsetting i bygdene rundt (FHBT, 2011, s. 11).

De fleste med lokal tilhørighet har en sterk tilknytning til Hardangervidda gjennom landbruk, jakt, fiske og annen høstingsbruk, noe som har vært viktig for forming av lokal identitet (FHBT, 2011, s. 11). Betydningen av bruksrettigheter knyttet til denne bruken, både når det gjelder tradisjon og økonomi, gjorde at forvaltningen av Hardangervidda skulle være mer liberal enn for andre nasjonalparker i landet, tilpasset både bruksinteressene og eiendomsforholdene (Meld. St. 62 (1991-1992), s. 24). Likevel førte det til sterk konflikt. Fortsatt er konfliktnivået i mange tilfeller høyt, blant annet i saker hvor kulturminner står sentralt. På grunn av den rike kulturhistorien og de mange kulturminnene som er registrert, ble Hardangervidda ansett for å stå i en særstilling blant 
fjellområdene i Norge (Meld. St. 43 (1978-1979), s. 16). Forut for etableringen ble nasjonalparken omtalt som et «naturområde og kulturdokument» i de offentlige utredningene (NOU 1974: 30A, s. 8). Forvaltning av området handler derfor om vanskelige avveininger mellom både natur og kultur, vern og bruk.

Det som imidlertid ofte ikke tas stor nok høyde for å forstå slik konflikt, er tradisjoners betydning og kulturarvens sterke personlige, affektive verdi. Karakteristisk for Hardangervidda er alle de mange gamle buene for husly i stein og tre som eksisterer rundt om i fjellet. Mange har falt i ruin, men mange er også fortsatt i bruk. Karakteristisk er i tillegg slepene, som i århundrer har vært brukt til ferdsel, føring av buskap og til driftetrafikk - og som i dag brukes både av fotturister og er nødvendige til lokal transport. Dette er kulturminner som har høy verdi både i et lokalt og nasjonalt perspektiv. Kulturminnemyndighetene rangerer dem som nasjonalparkens viktigste kulturhistoriske verneverdier (FHBT, 2011, s. 11). Vern prioriteres framfor bruk, hvor antikvarisk verdi og opplevelse av fysisk form og estetikk skal veie tungt. Som hovedregel er det ikke lov å gjenreise gamle buer som bare er en ruin, eller å endre stående buer når det gjelder tradisjonell form og materialbruk. Det skal i prinsippet heller ikke bygges noe nytt. Ferdselen på slepene er også strengt regulert, selv om det ikke er uvanlig å møte traktorer langt inne i nasjonalparken i forbindelse med reinjakt og annen virksomhet, noe som viser at forvaltningen er tilpasset lokale behov, og at området er i aktiv bruk.

Kulturminneforvaltningen har opp igjennom blitt kritisert for å legge altfor stor vekt på vern framfor bruk, noe som fører til en død kulturarv frosset i tid og rom. Den historiske bruken og brukssammenhengen i landskapet kommer ikke fram. Mange lokalt rundt Hardangervidda har vært frustrerte over restriksjoner som har kommet som følge av nasjonalparkens vern, som de mener har tatt fra dem rettigheter og muligheter for konvensjonell drift, har gått ut over økonomi, ført til at bygninger forfaller og at landskapet er grodd igjen. Til tross for dette er lokalbefolkningens bruk av Hardangervidda - om enn endret - likevel stor. Det er blant annet flere titalls tusen sauer på beite, og jakt og fiske drives i utbredt grad. Det er ressursbruk som har røtter i en svært lang tradisjon. Selv om mye av landskapets gamle kulturpreg er borte, og kulturbetingete 
arter og naturtyper forsvinner, finnes det fortsatt en sterk tilknytning til landskapet som oppleves å ha kontinuitet. Dette blir del av en vital kulturforståelse og lokal identitet, sammenvevd med erfaringer gjennom nåtidig bruk.

Samtidig finnes et variert kulturhistorisk engasjement. I et område jeg kjenner godt, som er utpekt som satsingsområde for kulturbasert reiseliv, er også det gamle åpne kulturlandskapet fortsatt grovt sett å kjenne igjen, selv om det er relativt få dyr på beite og bare én støl i drift. Folk lokalt har et engasjement for å vise fram og formidle områdets kultur, knyttet som den er til både nasjonal historie og egen tidligere drift, egne bygningers byggeskikk og det som har vært eget levd liv. For de som har tilknytning til området gjennom nåtidig eller tidligere virksomhet, vil landskapet, kulturminner og kulturhistorie ha en sterk affektiv verdi. Det er knyttet til mange erfaringer og minner som gjør opplevelsen personlig og betydningsfull fordi det oppleves nært og familiært. Innenfor kulturarvsforskning har dette nære perspektivet blitt en sentral inngang for å forstå kulturarvsengasjement og hva kulturarv betyr for folk i en hverdagslivssammenheng (f.eks. Auclair \& Fairclough, 2015; Byrne, 2008; Giaccardi, 2012; Gibson \& Pendlebury, 2009; Robertson, 2012; Schofield, 2014). Det viser spennet i hva kulturarv er, og hvorfor kulturarv skaper det som i faglitteraturen kalles dissonans (Robertson, 2012, f.eks. s. 8; Smith, 2006; Tunbridge \& Ashworth, 1996).

\section{Kulturell dissonans}

I mange saker knyttet til konflikt mellom vern og bruk, kommer kulturarvens dissonans tydelig fram. Ulike grupper knytter ofte ulike fortellinger og verdier til samme historiske objekt, landskap eller tradisjon. I 2019 raste en heftig debatt om en setergrend i Vesllie på Dovre, som året før var blitt besluttet revet i forbindelse med utvidelsen av Dovre-Sunndalsfjella nasjonalpark, og nå var i ferd med å bli effektuert. Det militære skytefeltet på Hjerkinn var avviklet i 1999, og et enormt oppryddings- og naturrestaureringsprosjekt var blitt satt i gang for å tilbakeføre arealet til en mest mulig naturlig tilstand og innlemme det i den eksisterende nasjonalparken. Normalt er eldre setre som disse av høy kulturminneverdi, slik det 
også er en prioritet i Riksantikvarens fredningsstrategi (RA, 2015). De eldste bygningene var fra 1870-årene, da seterdriften i Vesllie opprinnelig ble etablert. I 2018 hadde Riksantikvaren imidlertid avvist en forespørsel om å frede setrene (KMD, 2019). I avveining mellom kulturminneverdier og villrein, var det hensynet til villreinen som veide tyngst (KMD, 2019). Det var viktig å sikre en av de siste villreinstammene i Europa, som Norge har et spesielt ansvar for å ivareta. Det ble framholdt at riving av setrene ville redusere ferdsel, noe som skal ha vært nødvendig for å ta vare på villreinen fordi dyrene påvirkes sterkt negativt av menneskelige forstyrrelser.

Beslutningen om å rive setrene møtte sterk motstand fra lokalt hold. Det ble gitt uttrykk for at setrene var viktige kulturminner for lokalsamfunnet. En aksjonsgruppe samlet 16 ooo underskrifter for bevaring av setrene, og 100 demonstranter møtte opp for å vise motstand mot riving. Dovre nasjonalparkstyre ville bevare setrene. Det ville også foreningene Norsk Kulturarv og Fortidsminneforeningen. Mange krevde at Riksantikvaren skulle vurdere fredning. Klima- og miljødepartementet fastholdt imidlertid vedtaket om riving på grunn av villreinen, og Riksantikvaren ville heller ikke sette i gang noen fredningssak. Forkjemperne skrev blant annet: «Elvestuen [statsråden i KMD] har nok ikke skjønt hva kulturarv og lokalhistorie som seterbruk og sameksistens mellom folk og fjell, betyr for Norge og de som bor her» (Facebook-post, 19.8.2019), «Seterbruket har lange og sterke tradisjoner i Fjell-Norge» og «en viktig del av vår kulturhistorie» (Jordhøy \& Botheim, 2019). Det ble også sterkt understreket at setrene kunne få viktig bruksverdi for beitebruk eller fjelloppsyn.

Det er likevel påfallende at et vedtak om riving av setergrenda skapte så stor oppmerksomhet og motstand. Bygningene hadde ikke vært i bruk til setring siden 1960, da Forsvaret overtok dem, og de var heller ikke særlig godt bevart (Jerpåsen et al., 2003, s. 31). Motstanden viser hvilken betydning de likevel kan ha. Lokal verdsetting handler ikke nødvendigvis om antikvarisk verdi, eller i hvilken grad seterpreget var forringet av offentlig eie, som var sterkt medvirkende til at bygningenes kulturminneverdi ikke ble høyt verdsatt av eksperter på feltet (Jerpåsen et al., 2003, s. 31). Som del av lokal verdsetting og kulturarvsforståelse kan verdien være 
mer knyttet til lokal historie, stedsidentitet og bruksverdi. Det er åpenbart at lokale behov og lokal verdsetting av setrene som kulturminner ble undervurdert fra nasjonale myndigheters side. De underslo også kraften som ligger i kulturminners bruksverdi, og dermed også forholdet til lokal $ø$ konomi. Til dette kom også en provokasjon mot lokalsamfunnene, idet veien forbi setrene skulle få bli liggende for å frakte turister som ledd i det naturbaserte reiselivet på stedet med tusenvis av besøkende hvert år.

Under overflaten av slike motsetninger finnes mange faktorer som kan samvirke og spille en rolle for hvordan kulturarv får mening og forstås. Kulturarv kan bli dissonant når den produseres i ulike sosiale, kulturelle og politiske kontekster. For under overflaten av konflikter knyttet til kulturarv, ligger nettopp at kulturarv har ulik verdi og betydning for ulike grupper. Samtidig viser nok konflikten om setrene på Dovre at den blandes inn i gamle samfunnsmessige skillelinjer, slik som en dypereliggende sentrum-periferi-problematikk. Et poeng for dette kapitlet, er at konflikten og engasjementet om setergrenda Vesllie viser at kulturarv ikke nødvendigvis er noe gitt, men kan blir formet og bli noe aktivt når noe som har med fortiden å gjøre faktisk kommer i spill. Økt oppmerksomhet og betydning av kulturminner kan dermed ha som en nedside at konfliktnivået går opp. Samtidig er det også et tegn på at kulturarv kan engasjere stort. Konflikten om setrene i Vesllie endte med at én av de to setrene i setergrenda ble bevart, som følge av den store, lokale motstanden. Dette kan ses som uttrykk for at autoriteter på kulturarvsfeltet og dominerende diskurs ikke nødvendigvis vinner fram - lokalt baserte måter å verdsette kulturarv på kan ha en like stor rett.

\section{Retten til egen kulturarv}

Konflikter knyttet til kulturminner, og kulturarvens iboende dissonans, peker mot et spørsmål om hva kulturarv er og kan være som demokratisk ressurs. Demokratisk medvirkning har blitt sentralt for offentlig kulturmiljøforvaltning, basert som den er på internasjonale avtaler som FARO-konvensjonen (2005) og Den europeiske landskapskonvensjonen (ELC) (Europarådet, 2004), som knytter kulturarv til demokratibygging. FARO-konvensjonen tar utgangspunkt i menneskers rett til kulturarv, og 
retten til å kunne tolke egen historie og egne kulturminner (Europarådet, 2009). Det nyskapende med denne konvensjonen var at den flytter perspektivet fra de fysiske kulturminnene til kulturarvens verdi for mennesker og dens funksjon i samfunnet. Konvensjonen slår fast at alle kulturarvsfellesskap (heritage communities) skal kunne få sine kulturminner beskyttet. Den går imidlertid videre, og retter oppmerksomheten mot enhvers mulighet til å være med å kunne å identifisere, fortolke og bevare kulturarv. Som en miljøressurs skal kulturarv bidra til bærekraftig utvikling, både i sosial, kulturell og økonomisk forstand. Men som demokratisk ressurs, handler det om at kulturarv er en viktig del av en rett folk skal ha til å delta i samfunnets kulturelle liv (Europarådet, 2009).

Dette betyr i realiteten å ikke bare åpne for, men også aktivt legge til rette for, mange og et mangfold av kulturarvspraksiser. Det handler både om å bevare mange forskjellige kulturminner, tradisjoner og kulturelle uttrykksformer, og gi rom for tolkninger og verdsetting som kan bygge identitet, skape engasjement og føre til et rikt kulturelt liv. Kulturarv har i lang tid vært knyttet til store og mindre kollektiv, være seg nasjonale fellesskap eller etniske og religiøse grupper. UNESCO har dessuten bidratt til en globalisering av kulturarv, og pekt ut kulturarv som er fellesmenneskelig og universell. De siste par tiårene har det imidlertid vokst fram en forståelse av at kulturarvsfellesskap også kan være alle mulige andre kulturelle og sosiale fellesskap, men også at en viktig dimensjon ved kulturarv er relasjonen til folks egne måter å skape mening, verdsette og oppleve sine omgivelser. Da er det kulturarv på det private og personlige plan. Dette har fått generalsekretæren for den norske Fortidsminneforeningen - med henvisning til FARO-konvensjonen og den retten enhver skal ha til en kulturarv - til å snakke om «enhver manns verdier» (Fjeldheim, 2021).

Også den Den europeiske landskapskonvensjonen (ELC) fra 2004 setter det menneskelige perspektivet og prinsippet om demokratisk medvirkning i sentrum. Konvensjonen (Europarådet, 2004) definerer et landskap på et svært relativistisk vis - som et område slik folk oppfatter det («an area, as perceived by people»). Et landskap er kulturelt, uansett hvor naturlig det måtte være, fordi det erfares av mennesker. Dette essensielt kulturelle aspektet, som konvensjonen er bygget på, handler 
om betydningen av menneskers stedsbaserte identitet (Fairclough, 2016, s. 149). Det er med andre ord knyttet til kulturarvsverdi. Når konvensjonen, som den gjør, også legger opp til en bred forankring og folkelig deltakelse i forvaltningen av landskap, hvor tradisjonell, lokal og erfaringsbasert kunnskap om natur- og kulturforhold skal være inkludert, er kulturarvens immaterielle dimensjon helt sentral.

Det brede miljøpolitiske feltets lovverk, utvikling og trender vitner om hvordan kulturarvsbegrepet har vokst i betydning og også blitt tett koblet til oppfatning, bevaring og forvaltning av natur. Dette har endret både kulturminneforvaltningen og naturforvaltningen på grunnleggende vis. Brundtland-rapporten ble et veiskille i tenkningen om sammenhengen mellom natur og kultur. Fem år senere ble kulturmiljøbegrepet introdusert i kulturminneloven, for, som det heter, å bevare «områder hvor kulturminner inngår som del av en større helhet og sammenheng» (Kulturminneloven, 1978, \$2). I tillegg ble kulturlandskap et annet sentralt forvaltningsbegrep. Med den nye naturmangfoldloven av 2009, som erstattet naturvernloven fra 1970, ble dessuten kulturverdier og kulturminner nevnt og del av naturforvaltningens ansvarsfelt. Natur og kultur hadde ikke lenger et klart skille. Med den siste stortingsmeldingen på feltet, hvor kulturminnepolitikken har fătt endret navn til kulturmiljøpolitikk, er en integrert forståelse av natur og kultur blitt manifestert (Meld. St. 16 (2019-2020)). Utmarka er et godt eksempel på et landskap hvor grensen mellom natur og kultur vanskelig kan trekkes, som er arealer som kan framstå som mye natur, men som er definert som landskap ut fra å være del av landbrukskultur. Formålet i dette kapitlet har imidlertid vært å vise at selv om utmarka er i endring med redusert konvensjonell bruk, og i så måte kan assosieres i større grad med natur, har kulturarvsverdiene fått økt oppmerksomhet og kommer til uttrykk på mange forskjellige vis.

\section{Kulturarv i utmark}

Det er betimelig å spørre om utmarka har blitt historie. Den konvensjonelle bruken knyttet til landbruk har gått drastisk ned. Store områder som før var nødvendige i næring og for livsopphold, har blitt verna på grunn av at de anses å ha helt unik naturverdi. Utmarka er likevel ikke 
historie. Mange steder er utmarksbruken fortsatt stor, selv om den har endret betydelig karakter. Det er et landskap i endring, både fordi det mange steder gror igjen, og fordi det er gjenstand for en annen kulturforståelse og har fått et annet kulturelt preg. Ikke minst peker interessen for kulturminnene og kulturhistorien i utmarka mot en ny tid, som kan erstatte noe av det som har vært utmarkas tidligere primære bruk. Det gjøres både offentlig og privat innsats for å tilby opplevelser og verdiskaping for lokalsamfunnenes sosiale, kulturelle og økonomiske bærekraft.

Om dette ikke gir aktivitet i samme omfang som tidligere land- og høstingsbruk, er utmarkas kulturarv uansett i søkelyset som aldri før. Lowenthal $(1998$, s. 10) konstaterte at kulturarv er et økende fenomen fordi det er flere mennesker som er opptatt av det. Det er kulturarv også fordi det er så mye mer som forbindes og får betydning som kulturarv nå enn før. Rodney Harrison (2013, s. 69) skriver: «We have seen a dramatic and exponential growth in the number and rage of objects, places and practices that are defined, conserved and exhibited as 'heritage'». Det gjelder også i utmarka. Selv de mest unnselige og nedfalte buer og oppkjørte veier, slik vi for eksempel kan finne på Hardangervidda, er blitt en viktig del av det som er definert som kulturarv, i like med rivningstruete setre på Dovrefjell. Det finnes betydningsfull kulturarv selv i områder som først og fremst er verna og kjent på grunn av sin natur. Utmark er et landskap i endring, og forandres gjennom både bruksendring og skiftende politiske mål. Det er opprettelse av naturvernområder et tydelig eksempel på. Det er samtidig landskap som endrer seg konseptuelt, slik som når offentlige myndigheter bidrar gjennom sin forvaltningspolicy og praksis til å framheve dets kulturhistoriske karakter, og i praksis gjøre det til et kulturarvsted, selv når det har fått nasjonalparkstatus. Det skjer også på lokalplan, når utmarkas kulturarv får økt betydning for folk, og når kulturarv ikke bare peker bakover, men framover - mot en tid der utmarkas kulturminner forventes å skulle ha et stort utviklingspotensial.

\section{Referanser}

Association of Critical Heritage Studies. (2012). History. 2012 Manifesto. https://www. criticalheritagestudies.org/history 
Auclair, E. \& Fairclough, G. (2015). Living between past and future: An introduction to heritage and sustainability. I E. Auclair \& G. Fairclough (Red.), Theory and practice in heritage and sustainability. Between past and future (s. 1-20). Routledge.

Byrne, D. (2008). Heritage and social action. I G. Fairclough, R. Harrison, J. Schofield \& J. J. Jameson (Red.), The heritage reader (s. 149-173). Routledge.

Christensen, A. L. (2011). Kunsten å bevare. Om kulturminnevern og fortidsinteresse $i$ Norge. Pax Forlag.

Davison, G. (2008). Heritage. From patrimony to pastiche. I G. Fairclough, R. Harrison, J. Schofield \& J. J. Jameson (Red.), The heritage reader (s. 31-41). Routledge.

Europarådet. (2004). European landscape convention. Council of Europe. https:// www.coe.int/en/web/conventions/full-list/-/conventions/treaty/176

Europarådet. (2009). Heritage and beyond. Council of Europe.

Fageraas, K. (2019). Verdensarven på Vega-mellom internasjonale konvensjoner, nasjonal politikk og lokale praksiser i et nordnorsk øysamfunn [Doktorgradsavhandling]. Universitetet i Oslo.

Fairclough, G. (2016). Essentially cultural: Perspectives on landscape from Europe. Landscape Journal: Design, Planning, and Management of the Land, 35(2), 149-166.

Fjeldheim, O. H. (2021, 30. januar). Kulturminnevernets verdier. Vi trenger en diskusjon. Fortidsminneforeningen. https://fortidsminneforeningen.no/aktuelt/ verdier-i-kulturminnevernet/

Fylkesmannen i Hordaland, Buskerud og Telemark. (2011). Forvaltningsplan. Hardangervidda nasjonalpark med landskapsvernområde. https://felles.naturbase. no/api/dokument/hent/9039.PDF

Giaccardi, E. (Red.). (2012). Heritage and social media. Understanding heritage in a participatory culture. Routledge.

Gibson, L. \& Pendlebury, J. (Red.). (2009). Valuing historic environments. Ashgate.

Graham, B. J., Ashworth, G. J. \& Tunbridge, J. E. (2000). A geography of heritage: Power, culture and economy. Arnold Press.

Harrison, R. (2013). Heritage. Critical approaches. Routledge.

Jerpåsen, G. B., Risåsen, G. T. \& Binns, K. S. (2003). Tilbakeføring av Hjerkinn skytefelt til sivile formål. Tema kulturmiljø og kulturminner (NIKU-rapport 02/03). Norsk institutt for kulturminneforskning.

Jordhøy, P. \& Botheim, O. J. (2019, 24. juli). «Kanoner mot spurv» på Dovrefjell [Kronikk]. Nationen. https://www.nationen.no/motkultur/kronikk/kanoner-motspurv-pa-dovrefjell/

Klima- og miljødepartementet. (2019, 12. august). Hensynet til villreinen prioriteres på Hjerkinn. https://www.regjeringen.no/no/dokumentarkiv/regjeringen-solberg/ aktuelt-regjeringen-solberg/kld/nyheter/2019-nyheter/hensynet-til-villreinenprioriteres-pa-hjerkinn/id2663835/ 
Klima- og miljødepartementet. (2020a). Tildelingsbrev 2020 for Riksantikvaren. https://www.regjeringen.no/contentassets/ofdb7d48c07849eea3749623dc4c59b9/ riksantikvaren-2020.pdf

Klima- og miljødepartementet. (2020b). Klima- og miljødepartementets historikk. https://www.regjeringen.no/no/dep/kld/dep/historikk/id696/

Kulturminneloven. (1978). Lov om kulturminner (LOV-1978-06-09-50). Lovdata. https://lovdata.no/lov/1978-06-09-50

Logan, W., Kockel, U. \& Craith, M. N. (2016). The new heritage studies. Origins and evolution, problems and prospects. I W. Logan, M. N. Craith \& U. Kockel (Red.), A companion to heritage studies (s. 1-26). Wiley Blackwell.

Lowenthal, D. (1998). The heritage crusade and the spoils of history. Cambridge University Press.

Lundberg, A. K., Hongslo, E., Hovik, S. \& Bay-Larsen, I. (2013). Hva skjer i den nye lokale forvaltningsmodellen for verneområder? En forskningsstatus. Utmark tidsskrift for utmarksforskning, (1).

Meld. St. 64 (1965-1966). Om Naturvernrådets innstilling om landsplan for natur- og nasjonalparker i Norge. Kommunal- og arbeidsdepartementet.

Meld. St. 43 (1978-1979). Om Hardangervidda. Miljøverndepartementet.

Meld. St. 62 (1991-1992). Ny landsplan for nasjonalparker og andre større verneområder $i$ Norge. Miljøverndepartementet.

Meld. St. 16 (2019-2020). Nye mål i kulturmiljøpolitikken - Engasjement, borekraft og mangfold. Klima- og miljødepartementet.

Miljødirektoratet \& Riksantikvaren. (2015). Kulturminner i områder vernet etter naturmangfoldloven. Veileder/rapport, M-420, 2015. https://www.miljodirektoratet. no/globalassets/publikasjoner/m420/m420.pdf

Molaug, P. B., Sollund, M.-L. B. \& Sæterdal, A. (Red.). (2004). Kulturmiljøbegrepet som teoretisk/analytisk begrep og som praktisk begrep for forvaltningen? Rapport fra NIKUs forskerverksted 30.08.2004 (NIKU-rapport 29). Norsk institutt for kulturminneforskning.

NOU 1974: 30A. (1974). Bruken av Hardangervidda. Miljøverndepartementet.

Nærings- og handelsdepartementet. (2012). Destinasjon Norge. Nasjonal strategi for reiselivsnoringen. https://www.regjeringen.no/globalassets/upload/nhd/vedlegg/ rapporter_2012/reiselivsstrategien_april2012.pdf

Prop. 1 S (2019-2020). Proposisjon til Stortinget (forslag til stortingsvedtak). Klima- og miljødepartementet.

Riksantikvaren. (2015). Riksantikvarens fredningsstrategi mot 2020/Vedlegg 1. Riksantikvaren.

Robertson, I. (Red.). (2012). Heritage from below. Routledge.

Ronström, O. (2007). Kulturarvspolitik. Visby, från sliten småstad till medeltidsikon. Carlssons. 
Schofield, J. (2014). Who needs experts? Counter-mapping cultural heritage. Ashgate. Smith, L. (2006). Uses of Heritage. Routledge.

St.prp. nr. 65 (2002-2003). Tilleggbevilgninger og omprioriteringer i statdsbudsjettet medregnet folketrygden 2003. Finansdepartementet. https://www.regjeringen.no/ no/dokumenter/stprp-nr-65-2002-2003-/id138427/

Tolia-Kelly, T., Waterton, E. \& Watson, S. (2018). Heritage, affect and emotion: Politics, practices and infrastructures. Routledge.

Tunbridge, J. E. \& Ashworth, G. J. (1996). Dissonant heritage. The management of the past as a resource in conflict. Wiley.

World Commission on Environment and Development. (1987). Our common future. Oxford University Press.

Aas, Ø., Vistad, O. I., Dervo, B., Eide, N. E., Kaltenborn, B. P., Haaland, H., Andersen, O., Svarstad, H., Skår, M. \& Nellemann, C. (2003). Bruk og forvaltning av nasjonalparker i fjellet (NINA fagrapport 72). Norsk institutt for naturforskning. 



\title{
KAPITTEL 11
}

\section{Utmarksetikk i endring?}

\author{
May Thorseth \\ Norges teknisk-naturvitenskapelige universitet (NTNU)
}

\begin{abstract}
Established ethical norms and standards are challenged by the changed use of the outfields (utmark). This chapter undertakes some basic ethical reflections of sustainable governance, strong sustainability and intergenerational justice with respect to the outfields. Basic assumptions about the quality of the outfields are presented. Most importantly, it is argued that sustainability should take its point of departure in a concept of strong sustainability, which implies that the outfields should be conceived of as commons rather than commodities. A critique with a Lockean, liberal understanding of natural resources is put forth, aimed at showing why an individual and anthropocentric framework is insufficient for true sustainable governance. The main reason for this is that nature and natural resources embed values that are complementary to, but not interchangeable with, economic values. A couple of examples of contested commons are presented, in order to demonstrate why commons rich in natural resources must be governed as global property. Fundamentally, this is due to intergenerational justice, which has received worldwide support ever since the UN report Our Common Future was published in 1987.
\end{abstract}

Keywords: commons, intergenerational justice, outfields, strong sustainability, sustainable governance

\section{Innledning}

Endringer i bruken av utmarka utfordrer etablerte etiske standarder for bruken. Fra opprinnelig å være mark som ingen behøvde å konkurrere om, er utmarka i vår tid under sterkt press fra ulike interessenter. Det er ikke lenger nok med selvregulering, og det juridiske systemet for regulering av bruken er omfattende. Men regulering løser ikke alle problemer, 
spesielt ikke når det hersker uenighet om legitim bruk av utmarka. Etiske standarder for bruken var tidligere nedfelt i kulturen. Med endret bruk er det behov for eksplisitt debatt om etiske standarder for bruken. Mens juridifiseringen har kommet langt, vitner stor uenighet om at den etiske refleksjonen i samfunnet har kommet for kort. Dette kapitlet har som mål å utdype forståelsen av noen etiske dilemma som ikke løses ved juridisk regulering alene.

Men aller først må vi avklare hva vi mener med «utmarka»: «Utmark er alt som ikke regnes for innmark etter friluftsloven, slik som skog, fjell og kystområder [...] [Fra] 2012 regnes skogplantefelt som utmark. Etter allemannsretten har allmenheten rett til fri ferdsel, opphold og høsting i utmark» («Utmark», 2021).

Ut fra friluftslovens tolkning har Høyesterett i noen saker bl.a. definert inn også nedfart til alpinanlegg (selv om terrenget er bearbeidet), og har ellers avgjort i hver enkelt sak hvor grensen skal trekkes mellom innmark og utmark. I mange saker dreier det seg om grensedragninger i strandsonen. Sentralt i mange saker er at grunneiere har krav på privat sone rundt bebyggelse. Loven om motorferdsel (1977) har en videre definisjon enn friluftsloven, som omfatter setervoll, hustomt, engslått og kulturbeite.

I dette kapitlet følger vi friluftslovens definisjon uten å gjøre spissfindige grensedragninger. De viktigste momentene er (1) skog, fjell, vann og strandsoner som ikke er definert som innmark, og (2) områder der allemannsretten gjelder.

Andre kapitler i boka drøfter juridiske, biologiske, kulturelle og organisatoriske aspekter, noen med spesielt søkelys på rein eller sau. En overordnet problemstilling gjelder hva slags verdier samfunnet ønsker å tilskrive utmarka. En viktig skillelinje i endret bruk gjelder enten vern eller verdiskaping. Spørsmål om vern, bruk og (økonomisk) verdiskaping kan imidlertid ikke alene avklares gjennom presiseringer av det juridiske regelverket. Hvordan skal vi håndtere områder som tilhører fellesskapet, samtidig som det f.eks. kan ligge på privat grunn? Standardbegreper om eiendomsrett passer ikke helt, for det er ikke kun opp til f.eks. grunneieren å forvalte utmarka etter eget forgodtbefinnende. Noe som også tilhører fellesskapet kan ikke uten videre selges for helt andre formål på et fritt marked. Men hva slags rettigheter skal gjelde da? Grunnleggende 
etiske intuisjoner utfordres, og etiske normer og prinsipper står på spill. Hvordan skal vi prioritere når kulturminner står i veien for utbygging, og hva med retten til kulturelt betinget husdyrhold som trues av andre næringsinteresser, som utbygging av hyttefelt eller vindmølleparker? Og hva skal veie tyngst når hensynet til bærekraft og framtidige generasjoner trues av kortsiktig økonomisk gevinst? Disse spørsmålene peker på noen av de mange etiske utfordringene og dilemmaene som ulike myndigheter og allmennheten må ta stilling til. Her skal vi se nærmere på noen grunnleggende områder for etisk refleksjon og noen etiske dilemmaer knyttet til boerekraftig bruk, eiendom, grenser og rettferdighet. Noen av dilemmaene tydeliggjøres ved å sammenlikne med allmenninger også andre steder i verden.

\section{Bærekraftig bruk av utmarka}

Bruken av utmarka har aldri vært friksjonsfri, det ligger i sakens natur: jakt og fiske, husdyrhold, fritidsinteresser og verneinteresser har også tidligere skapt konfliktlinjer av ulike slag. Som flere av kapitlene i boka her peker på, har det likevel vært etablerte standarder for bruk som har vært akseptert av de fleste - eksempelvis har bønder som driver med husdyrhold i uminnelige tider sendt dyrene på utmarksbeite, mens allmenningen også har vært brukt til jakt og matsanking uten at det har skapt nevneverdig konflikt. Nye momenter som har skapt konflikter er ofte knyttet til oppfordringen om å bruke utmarka til verdiskaping ut over tradisjonell bruk, tydelig eksemplifisert gjennom utbygging av vassdrag, store hyttefelt og vindmølleparker. Vern eller utbygging er én av de grunnleggende konfliktlinjene som krysser etablerte skillelinjer mellom by og land, mellom grunneier og myndigheter, mellom forvaltning og sårbare næringer som sauehold og spesielt reindrift.

Likevel, på tvers av disse dels gamle og mange nye frontene er det likevel utbredt enighet om viktigheten av bærekraftig forvaltning av ressursene i utmarka. Men hva innebærer det?

Definisjonen av bærekraft i Brundtland-rapporten Vår felles framtid fra 1987 identifiserte tre viktige dimensjoner: økologisk, sosial og økonomisk bærekraft, med vekt på at behovene til dagens mennesker dekkes 
uten at det svekker grunnlaget for framtidige generasjoner. De aller fleste er enig $i$ at alle tre dimensjoner er viktig, men ikke alle er enig $i$ at alle tre er like viktige: Fra grunneierperspektiv mener mange at næringsinteressene er viktigst, og plasserer økonomisk bærekraft i sentrum. Andre vektlegger mest retten til å opprettholde tradisjonell bruk av utmarka, og fokuserer heller på sosial bærekraft. En god del mener imidlertid at hensynet til bevaring av naturmangfold og vern om allmenningen for alle er viktigst, og vektlegger mest økologisk bærekraft. Som mange av kapitlene i denne boka viser, er det nettopp uenigheten om tyngden av de ulike dimensjonene som ofte skaper konflikt. Mens reindriftseieren er opptatt av å bevare egen næringsvei, kan begrunnelsen være både sosial/kulturell og økonomisk - å bevare identitet og kultur kan ikke skilles fra behovet for økonomisk bærekraft. I kontrast til dette kan også kommunene som ønsker hytteutbygging være interessert i økologisk og kulturell bærekraft, men tyngdepunktet ligger utvilsomt på økonomisk bærekraft for kommunen og innbyggerne. Hvem sine interesser skal veie tyngst? I likhet med reineieren som ikke ønsker hytteutbygging på sommer- eller vinterbeiter for reinen, er det også andre grunner til å ikke ønske utbygging av store hyttefelt; for eksempel verneinteresser og bevaring av uberørt natur. Men selv ut fra verneinteresser kan begrunnelsen variere: Mens noen setter søkelys på bevaring av utmarka som allmenning for eksisterende og kommende generasjoner, er det andre som heller vektlegger verdien av ubearbeidet natur fra et biologisk eller økologisk perspektiv. Verdien av bevaring kan dermed begrunnes fra to nokså ulike perspektiver - et antroposentrisk eller et bio-/økosentrisk perspektiv.

Uten å gå nærmere inn på de ulike perspektivene her, er det viktig å fremholde at det er stor forskjell på etisk begrunnelse som setter mennesket i sentrum i naturen (antroposentrisk), til forskjell fra å la naturen eller økosystemet selv i sentrum når verdier skal tilskrives (økosentrisk). Mens mange mener disse perspektivene er uforenlige, peker John Dryzek på at enhver slik «sentrisme» er problematisk (1995, s. 16-17). Ut fra en modell basert på deliberativt demokrati peker han på behovet for en mer egalitær utveksling mellom menneske og natur.

For diskusjonen om utmarka står ulike «sentriske» interesser ofte i konflikt. Om konflikten står om vern i motsetning til utbygging av et 
område kan begge partene være enig i et antroposentrisk perspektiv: Eksempelvis vil grunneieren verne sonen rundt egen innmark, mens utbyggeren vil være opptatt av veibygging til nytt hyttefelt. Verneinteresser kan imidlertid også være begrunnet i en annen type «sentrisme», som heller tar utgangspunkt i naturens egenverdi og behov for beskyttelse ut fra et mer helhetlig perspektiv.

Enighet om bærekraftig utvikling og bruk av naturressurser som utmarka innebærer dermed mange motsetninger og konfliktlinjer som dels bunner i ulike vektlegginger av de ulike dimensjonene av bærekraft, og hvorvidt perspektivet er antroposentrisk eller øko-/biosentrisk. De empiriske analysene i denne boka viser noe av mangfoldet i debatten om bruk av utmarka. Når vi i dette kapitlet ser debatten fra et etiskfilosofisk perspektiv, er det i stedet normative sider ved debatten vi er interessert i. Hvordan bør vi handle for å ivareta hva slags bærekraft? Da må vi begrunne hvorfor eksempelvis et antroposentrisk perspektiv skal trumfe et økosentrisk, eller om det er riktig å se disse som motstridende. En kjent konflikt i forståelsen av bærekraftig utvikling er dessuten om vi legger til grunn et begrep om svak eller sterk bærekraft. Svak bærekraft innebærer at «menneskelig kapital» kan erstatte «naturlig kapital», ${ }^{1}$ og betyr at man kan begrunne inngrep i naturen ved hjelp av teknologi så lenge summen av kapital er intakt. En slik økonomisk begrunnelse forutsetter at økonomiske, sosial-kulturelle og økologiske hensyn kan måles på samme skala, og at det er akseptabelt at naturlig kapital forringes så lenge økonomisk kapital styrkes. Utbygging av utmarka, vassdrag eller etablering av vindmølleparker kan enkelt begrunnes ut fra et begrep om svak borekraft.

I motsetning til svak bærekraft, innebærer sterk borekraft at økonomisk og miljømessig kapital er komplementære, men ikke utbyttbare. Sterk bærekraft kjennetegnes ved at de enkelte godene er uerstattelige; godene skal hver for seg være bærekraftige. Det betyr at man ikke må forbruke ikke-fornybare naturressurser, selv om det skulle føre til økonomisk gevinst.

1 Opprinnelig introdusert av nobelprisvinnerne Robert Solow og John Hartwick. 
Et klart eksempel på en ikke-fornybar naturressurs er ozonlaget, som ikke kan erstattes av menneskelig, økonomisk kapital (selv om man har lyktes i å reparere hull). Den grunnleggende uenigheten gjelder hvorvidt man tror at problemet med begrensede ressurser kan løses ved hjelp av teknologi eller ikke, og hvorvidt man anerkjenner at det fins grenser for vekst. Det økologiske perspektivet trumfer her det økonomiske, noe som først og fremst uttrykker et verdivalg. Om vi betrakter bruken av utmarka fra et svakt eller sterkt bærekraftbegrep kan dermed begrunne svært ulike verdivalg. Tap av beiteland for reineiere eller sauebønder er mye mer enn økonomisk tap som kan kompenseres, og er derfor vanskelig å begrunne ut fra et sterkt bærekraftbegrep. Med utgangspunkt i svak bærekraft vil det imidlertid være langt enklere å begrunne at tapet kan kompenseres økonomisk, fordi økonomisk kapital kan erstatte naturlig (miljømessig) kapital.

I tillegg til de tre dimensjonene (økologisk, økonomisk, sosial) og to definisjonene (sterk og svak) av bærekraft omtalt ovenfor, er det viktige juridiske og politiske sider ved bruk av utmarka som diskuteres i de øvrige kapitlene i denne boka. Her skal vi først se nærmere på eiendom og rettigheter med et kritisk blikk på et klassisk liberalt eiendomsbegrep.

\section{Eiendom og rettigheter}

Først vil vi klargjøre et viktig skille i synet på natur generelt, og utmarka mer spesielt. Mens svak bærekraft langt på vei betrakter naturen som en vare (commodity), vil sterk bærekraft legge vekt på natur og utmark som allmenning (common). Mens varer kan kjøpes og selges fordi noen eier varen, er en allmenning ikke til salgs fordi den tilhører fellesskapet. Selv om dette er en grov forenkling, peker det like fullt mot en viktig uenighet i synet på menneskets forvaltning av naturen. Dersom markeieren betrakter utmarka som privat eiendom kan vedkommende fritt selge den til høystbydende utbygger, selv om forvaltningen ofte er regulert av myndighetene. Poenget her er å vise at vareperspektivet skiller seg fra allmenningperspektivet ved at sistnevnte ikke kan kjøpes og selges på linje med andre varer ut fra en sterk bærekraftbegrunnelse: Den representerer verdier som ikke kan byttes ut med andre, som økonomisk 
kapital. Imidlertid vil en allmenning (common) kunne gjøres om til en vare (commodity) gjennom kultivering, og dermed gjøre krav på eiendomsrett. Et viktig spørsmål er om slike endringer i utmarka, forårsaket av kultivering av allmenningen, også kan gjøre krav på å være moralsk akseptable? Med utgangspunkt i et bærekraftbegrep som anerkjenner at visse ressurser ikke kan fornyes, og derfor ikke kan erstattes av andre, kan vi begrunne at utmarka ikke bør eies uten ansvar for å forvalte den til fellesskapets beste. Mye er skrevet om dilemmaer rundt overforbruk av allmenningen, spesielt godt kjent under betegnelsen «allmenningens tragedie» (tragedy of the commons), se bl.a. Hardin (1968). I korthet skisserer tragedien et paradoks dersom alle som bruker et område, f.eks. til beite, ønsker å øke sin profitt ved å ha bare ett dyr til på beite. Dersom alle tenker likt, vil imidlertid fellesgodet, altså allmenningen, forringes, og alle taper på at hver enkelt øker sin del. Det fører med andre ord til tap både for den enkelte og for fellesskapet.

Hvorvidt løsningen på tragedien krever statlig eller privat forvaltning, er et stort tema vi ikke skal utdype her. Hvorvidt politisk styring skal være generell med lokale tilpasninger, som Agenda $21^{2}$ eller som lokal selvstyring (jf. Ostrom, 1990/2015) skal vi heller ikke diskutere her. Vårt fokus er i stedet et mer grunnleggende etisk-filosofisk spørsmål om all ikke-menneskelig natur, som utmarka, skal betraktes som eiendom, og om retten til å styre den.

Når vi diskuterer endringer i bruk av utmarka, og endringer i etiske begrunnelse for disse endringene, er det interessant å se på en klassisk begrunnelse for tilskriving av rettigheter. Ifølge filosofen Locke oppstår eiendom ved at noen først har tatt noe i besittelse gjennom bearbeiding. Helt konkret kan vi her tenke på dyrking av marka. Isak Sellanraa i Knut Hamsuns roman Markens grøde (1917) kan tjene som illustrasjon. Hovedpersonen Isak bearbeider utmarka slik at den endres til dyrkbar jord, og skaffer seg derigjennom en eiendom. Trekker vi paralleller til utmarka i dag, er det bare delvis sammenliknbart. Ulike interessenter bruker i dag utmarka for ulike formål: jakt, fiske, beite, rekreasjon,

2 Agenda 21 er en ikke-bindende aksjonsplan under FN mht. bærekraftig utvikling. Planen er et produkt av FNs 1992 Earth Summit (Rio-konferansen). 
hyttebygging eller vassdragsutbygging. Tillatelsen til bruk av utmarka er fra gammelt av en hevdvunnen rettighet. Ingen har tenkt på den som en eiendom i Lockes forstand, men snarere som en allmenning.

Endringen som skjer når utmarksområder bearbeides gjennom utbyggingsformål gjør derimot at rettighetene ikke lenger styres av hevdvunne rettigheter, men av markedsliberalistiske prinsipper for kjøp og salg. Utmarka er i utgangspunktet ubearbeidet natur som sakte endrer seg fra allmenning til vare. Med innføring av pengeøkonomi ble det mulig å transformere både bearbeidet og ubearbeidet natur til salgbar vare. Men det betyr også at utmarka derigjennom mister sin opprinnelige verdi som noe ikke-utbyttbart. Endret bruk av utmarka, som denne boka handler om, viser at kampen i dag nettopp står om forståelsen av utmarka som vare eller ikke. Det er lett å påvise at markeiere, utbyggere, reiselivsnæringer og friluftslivsentusiaster har dels motstridende interesser. Vanskeligere er det å begrunne at noen interesser bør prioriteres høyere enn andre. Med det spørsmålet beveger vi oss ut over hevdvunne rettigheter og jus og over til filosofien og etikken, som heller spør om legitimitet. Både hevdvunne rettigheter og moderne jus kan skille rett fra urett med referanse til hevd eller lovverk. Alle vet imidlertid at både hevd og lovverk kan være omstridt: Det er ikke sikkert det er riktig at vindmøller bør etableres i et bestemt område selv om det er gitt konsesjon, og det er heller ikke sikkert at salg av jordeiendom for utbyggingsformål i et område skal trumfe reineierens behov for beitemark i samme område. Spørsmålet er hvordan vi skal begrunne at et valg har høyere legitimitet enn et annet og derfor bør velges.

\section{Tre ulike begrunnelser}

I et illustrerende eksempel reflekterer filosofen og økonomen Amartya Sen (2009) over hvordan man skal fordele et knapt gode. Utgangspunktet er tre barn og bare én fløyte. Det ene barnet har laget fløyta, men kan ikke spille. Det andre barnet kan spille, mens det tredje barnet ikke har noen andre leker. Sen spør hvem som bør ha rett til fløyta. Her kan man grunngi tre ulike svar: (1) Den som har laget fløyta bør eie og fritt selge den, begrunnet ut fra prinsippet omfri handel. (2) Den som kan spille på 
fløyta bør eie den, begrunnet med evne. (3) Det siste barnet har ingen andre leker, og har dermed et behov for fløyta. Her skal vi avstå fra å konkludere, og i stedet trekke noen linjer fra fløyta til utmarka. Om vi ser utmarka som en salgbar vare, blir det viktig å tilskrive eierskap, jf. (1). Om vi derimot legger vekt på at tilgangen bør reguleres av de som har mest kunnskap, er vi nærmere begrunnelse (2). Ut fra (3) blir imidlertid begrunnelsen at utmarka er et knapt gode som ulike interessenter har behov for, og da bør vi prioritere de som har størst behov.

Vi kan da se for oss tre ulike utfall i henhold til de tre ulike begrunnelsene: Enten at de med størst kjøpekraft, eksempelvis markeieren eller kommunen, har størst rett; at de som har best kunnskap om bruken av utmarka, bl.a. ulike fagfolk, bestemmer; eller at de som ellers mangler og har størst behov for tilgang til fri natur for rekreasjon, bør prioriteres. Selv om vi vet at mange av disse interessene krysser hverandre, og vi kan finne en god del overlapp mellom ulike brukere, gjør det likevel stor forskjell hva slags prinsipp(er) vi legger til grunn. Den største utfordringen for utmarka - til forskjell fra fløyta - er kanskje ikke hvem som eier den, men snarere hvordan den brukes. En grunneier trenger ikke nødvendigvis å være mer interessert i økonomisk profitt på bekostning av vern, og en ihuga friluftslivsentusiast er heller ikke nødvendigvis imot enhver annen bruk av utmarka. Og mange sauebønder lever godt med hyttefelt så lenge det fins tilstrekkelig utmark til beiting. Utmarka er til for mange ulike interessenter - det avgjørende spørsmålet er hvordan vi regulerer bruken. I fortsettelsen skal vi derfor konsentrere oss om bruk framfor eierskap. Hva slags bruk bør vi stimulere, og hvilke grenser bør vi sette?

\section{Grenser for bruk = grenser for vekst?}

De fleste anerkjenner at utmarka er en allmenning til mangfoldig bruk. Så lenge det er nok til alle oppstår ingen større problem for hver enkelt interessent. Men i det øyeblikket allmenningen blir et knapt gode, oppstår behovet for grenser. For å unngå allmenningens tragedie må enten hver enkelt begrense sin bruk, eller vi må stenge ute visse typer bruk. Den politiske filosofen Locke, som ellers er en klassisk liberal tenker, er 
opptatt av hva som disponerer for retten til land forståt som bearbeidet natur: Når noen legger ned arbeid i å dyrke mark, gir dette rett til å eie marka. Dette gjelder så lenge det er nok til alle. Denne retten er imidlertid begrenset av to viktige premisser: 1) Det må være nok igjen til andre, den såkalte «enough and as good»-betingelsen, og 2) ingen må ta mer enn det man trenger, dvs. man skal bare tilegne seg det man kan bruke (Libell, 2011; Locke, 1690/2014, 2. T, kap. V, \$ 33). Ingen har rett til opphopning av ressurser som vil gå til spille før de blir brukt. Noe blir til eiendom ved «mixing labor with it» (Locke, 1690/2014, 2. T, kap. V, \$ 27), fordi enhver eier sin egen kropp og arbeidskraft. Likevel; ingen er fri til å utnytte ressursene betingelsesløst. Det må være nok igjen til andre, og man skal ikke kaste vrak på ressurser.

På Lockes tid er det primært snakk om tilgangen til land forstått som ubearbeidet natur, så lenge ingen har «mix[ed] labor with it». Locke kaller slik natur «unimproved», mens bearbeidet natur er «improved» ved hjelp av noens arbeid eller teknologi. Den grunnleggende tanken vi kan gripe fatt $\mathrm{i}$ for vår diskusjon om utmarka er imidlertid denne: Utmark som ennå ikke er tatt i bruk av noen er i prinsippet åpen for å bearbeides, eller tas i bruk for bestemte formål. Begrensningen er at man ikke legger marka øde, eller sløser med ressursene, og ikke hindrer andres bruk. Men hva betyr det?

Fra et utbyggerperspektiv vil mange mene at man sløser med ubrukt (ut)mark som potensielt kan transformeres til hyttefelt, vannkraft eller profitt for utbygger. Fra et naturvernperspektiv vil man i stedet forstå utbygging som krenkelse av «enough and as good»-betingelsen, tydeliggjort gjennom begrensninger for mange reineiere som mister tilgang til sommer- eller vinterbeite. Selv om Lockes politiske liberalisme klargjør hvorfor noen begrensninger på bruk av naturen er nødvendig, er det likevel uproblematisk, så lenge man tenker ut fra en dvs. eierskapsorientert (possessive) individualisme (Bailey \& Thorseth, 2017). De to betingelsene hos Locke viser at man kan finne et vern for allmenningen også innenfor en klassisk, liberalistisk tankegang. Men det forutsetter at man tar utgangspunkt i et menneskesentrert, såkalt antroposentrisk, perspektiv. Også fra et øko- eller biosentrisk perspektiv vil man akseptere at man må unngå å sløse med naturressursene, og sikre at det er nok igjen til andre. 
Begrunnelsen er imidlertid en helt annen. Fra et økosentrisk perspektiv er all natur av like stor verdi, og mennesket er selv en del av den samme naturen. Samtidig er det bare mennesker som har muligheten til å bearbeide naturen for egne eller felles formål. Kortsiktig økonomisk gevinst gjennom forbruk av ikke-fornybare naturressurser er uforenlig med sikring av tilstrekkelig tilgang for andre, og spesielt framtidige generasjoner. Dette kan man imidlertid være enig i enten man begrunner det antroposentrisk eller øko-/biosentrisk.

Endret bruk av utmarka er i flere av kapitlene i denne boka beskrevet som dreiningen mot å skape mer verdi, gjerne knyttet til endringen som skjedde under Sponheim (se kap. 1 og 7). I stedet for bare å la utmarka ligge brakk og dermed sløses bort, kom viktige insentiver om å maksimere verdien gjennom utbygging: turisme som hittil uutnyttet næring skulle stimuleres, og bønder skulle drive næring ut over å slippe dyrene på beite. Utbygging av turistnæringen krevde ny infrastruktur, som nye veier, tilgang til vann og kloakk med mer. Konsesjoner til vann- og vindkraftutbygging er også eksempler på utvidet bruk av utmarka, og dermed bidrag til å skape merverdi. Endret bruk av utmarka har dermed kastet mer av seg og medført merverdi både privat (for bønder og markeiere) og offentlig (for kommuner). Det prinsipielt nye er i begge tilfeller styrt av et overordnet ønske om å skape merverdi gjennom bearbeiding av natur, og føyer seg inn i en klassisk antroposentrisk liberalisme av Lockes type.

Et sentralt spørsmål er imidlertid hvorvidt (deler av) den endrede bruken ivaretar hensynet til andre, jf. Lockes «enough and as good»-proviso. Svaret kommer an på perspektivet man inntar: menneske- eller øko-/ biosentrert; lokalt/nasjonalt eller globalt; nålevende eller framtidige generasjoner? Utbygging av et hyttefelt i en norsk kommune bidrar utvilsomt både til flere arbeidsplasser og styrket kommuneøkonomi lokalt, men det er ikke like klart at det er lønnsomt ut fra et globalt klimaperspektiv. Utbygging av nye vannkraftverk eller annen industri i utmarka er kanskje enda klarere enn hytteutbygging eksempler på bearbeidet natur hvis konsekvenser er mer uklare i et langsiktig perspektiv.

To hensyn er spesielt relevant i situasjoner der vi må fatte beslutninger under usikkerhet: føre var-prinsippet og hensynet til framtidige 
generasjoner. Føre var-prinsippet ${ }^{3}$ ber oss om å unngå vesentlig skade på natur og miljø, og manglende kunnskap kan ikke brukes til å begrunne at vi unnlater å treffe tiltak. Der vi er i tvil om en utbygging eller endret bruk av utmarka er til gode for miljøet og naturen, tilsier prinsippet at vi skal la være. Grenser for vekst setter samtidig grenser for bruk: Dersom det hersker tvil, eller er omstridt, om en bestemt endret bruk av utmarka er bærekraftig, tilsier føre var-prinsippet at vi skal la være.

I tillegg til føre var-prinsippet, er det spesielt to andre forhold vi skal se nærmere på. Det ene handler om bærekraftig forvaltning, mens det andre gjelder rettferdighet innen og mellom generasjonene. Bærekraftig forvaltning er et normativt begrep, og konklusjonene man trekker avhenger av hva slags begrep om bærekraft man forsvarer. Vi tar utgangspunkt i et sterkt bærekraftbegrep som betyr at ikke-fornybare naturressurser ikke kan erstattes av menneskelig, økonomisk kapital. En riktig forvaltning av ikke-fornybare ressurser må ta økologiske, økonomiske og sosialt bærekraftige hensyn. I tillegg må den være rettferdig: Bærekraft kan ikke gjelde bare lokalt, eller for bare en liten gruppe, eller for bare en liten del av naturen. Og vi kan ikke snakke om bærekraftig forvaltning av ressursene uten å kreve at forvaltningen også må være rettferdig.

\section{Bærekraft og rettferdig forvaltning}

På overordnet nivå er det stor enighet om at naturinngrep må være både bærekraftige og rettferdige. Men hva innebærer det? For å kunne gi et etisk velbegrunnet svar er det nødvendig å foreta en analyse av konkrete saker.

Vi skal se på et par eksempel som reiser prinsipielle spørsmål om hvem som bør holdes ansvarlig for bærekraftig utvikling. Selv om disse eksemplene ikke er fra en norsk kontekst, er det nyttig for å løfte blikket ut over den norske utmarka når vi diskuterer begrunnelser for bruk av allmenninger.

Et inngrep som fremstår bærekraftig og rettferdig i én kontekst kan ikke alltid kopieres til enhver annen. Et typisk eksempel som illustrerer

3 Se f.eks. Holland (200o) om bærekraft. 
det er Agenda 21, som har som mål å bidra til bedre bærekraft, gi makt til lokalbefolkningen gjennom deltakelse og skape lokalt eierskap til prosjektene (se note 2). Fravær av demokratiske institusjoner eller dårlig koordinering mellom ulike lokale og nasjonale styringsnivå er typiske eksempler på det.

\section{Guangdong og lokal Agenda 21}

I Guangdong, en liten fiskeriprovins i Sør-Kinahavet, skulle lokal Agenda 21 løse problemet med overfiske og forurensning pga. rask økonomisk vekst (Ferraro, G. \& Bran, M., 2000 og Thorseth, 2015). En slående konflikt mellom beskyttelse av miljøet og økonomisk utvikling krevde handling. Et grunnproblem i dette tilfellet var imidlertid at ansvaret for miljøbeskyttelse ble delegert til Fisheries Management Bureau (FMB), som samtidig var eiere av den største fiskeribedriften. Bukken skulle altså vokte havresekken. En annen forklaring på hvorfor bærekrafttiltaket (lokal Agenda 21) ikke fungerte, handler om et annet grunnleggende problem: Behovet for økt bærekraft (mindre overfiske) konkurrerte med behovet for overlevelse. Den åpenbare grunnen er at fiske er den viktigste næringsveien i dette samfunnet.

En etisk utfordring her er hvorvidt man kan kreve at et lite lokalsamfunn skal velge å satse på bærekraftig utvikling på bekostning av overlevelse for innbyggerne. Overfiske og forurensing som skyldes strukturell urettferdighet og dårlig lokal styring av ressursene har konsekvenser av global rekkevidde. Det reiser et spørsmål om hvem som skal betale prisen: De som har skapt problemet, eller de som har best evne til å bøte på problemet? Mange inngrep - eller fravær av inngrep - har ofte konsekvenser som rekker langt ut over den lokale konteksten der problemet har oppstått. Går vi tilbake til fløyte-eksemplet, spurte vi hva som var mest rettferdig: den som har produsert fløyta bør eie den; den som kan spille bør eie den, eller den som har størst behov (har ingen andre leker) bør eie den. På liknende vis kan vi spørre hvem som skal bære ansvaret for dårlig bærekraft. På lokalt nivå i Guangdong er det kanskje ikke de fattige fiskerne som strever for å overleve; og antakelig er fraværet av tilstrekkelig koordinering mellom de nasjonale, regionale og lokale styringsnivåene 
mer ansvarlig enn de som har fått delegert ansvaret lokalt. Alle har et behov for miljømessig bærekraft, mens bare noen har evne til å bidra til det. Det er imidlertid lett å forstå at vi her snakker om en ikke-fornybar ressurs, nemlig havet med fisk, som ikke oppnår bærekraftig utvikling ut fra prinsippet om fri handel. Hovedgrunnen er at penger ikke kan erstatte rent hav og fisk - de er med andre ord komplementære, men ikke utbyttbare verdier (i henhold til sterk bærekraft). Penger kan ikke løse problemet, men de som har mest penger og makt bør pålegges et større ansvar.

Vi skal se på et annet eksempel som reiser liknende prinsipielle spørsmål om hvem som bør holdes ansvarlig for bærekraftig utvikling.

\section{Yasuni Ishpingo-Tambococha-Tiputini (Yasuni ITTI) $^{4}$}

Yasuni er en stor nasjonalpark i regnskogen i Ecuador, som absorberer karbondioksid fra atmosfæren og dermed er en viktig karbonbeholder. Nasjonalparken er viktig for å bevare biodiversitet, og den er viktig for å beskytte urbefolkningen som lever der. Da Ecuador oppdaget store oljereserver under Yasuni bestemte regjerningen seg i 2010 for å opprette Yasuni ITTI. Dette initiativet gikk ut på å opprette et fond for å dekke tap ved ikke å hente ut oljen. Målet var å få det internasjonale samfunnet til å være med på å betale prisen, gjennom økonomisk støtte fra NGO-er og andre lands regjeringer til et fond, som vilkår for ikke å hente ut oljen. Målet var å bevare biodiversitet, beskytte urbefolkningen og unngå frigjøring av $\mathrm{CO}_{2}$. Valget sto mellom å bevare regnskogen eller hente ut oljen. Begrunnelsen for initiativet var at valget hadde en rekkevidde av globalt omfang, og ikke burde være Ecuadors eneansvar.

Yasuni ITTI reiser flere etiske problemstillinger:

- Er dette initiativet eksempel på økologisk gisseltaking, dvs. trusselen om å sette i gang boring etter olje dersom det internasjonale samfunnet ikke vil betale?

4 Dette eksemplet er mer utførlig diskutert i Thorseth \& Schuppert, 2018. 
- Har Ecuador en rettferdighetsplikt til å bevare sin tropiske regnskog?

- Hvem skal styre/forvalte slike globale allmenninger (commons) på nasjonal grunn?

- Skal de som har bidratt mest til antropogenisk klimaendring, dvs. utslipp fra det globale Nord, bære kostnadene, eller skal fattige land som Ecuador betale prisen for utslipp de hittil ikke har bidratt til?

- Og hva med intergenerasjonell rettferdighet og ansvaret for framtidige generasjoner - kan det være et nasjonalt ansvar?

- Bør vi forstå oljeboring i regnskogen i Ecuador som brudd på miljøog andre rettigheter (naturen selv, urbefolkningen, eller menneskeheten globalt)?

Her skal vi konsentrere oss om tre forhold:

(1) Hvem skal forvalte nasjonale allmenninger som Yasuni - landet selv, eller det internasjonale samfunnet?

Sterk bærekraft setter et klart skille mellom allmenninger og utbyttbare varer, der bare sistnevnte kan være gjenstand for fri handel. Allmenninger som Yasuni innebærer med andre ord verdier som ikke kan innløses gjennom en pengetransaksjon. Både Ecuador og verdenssamfunnet anerkjenner dette, tydeliggjort ved Yasuni ITTI-initiativet. I denne saken er det snakk om å avstå fra ytterligere forurensing for å bevare en viktig natur- og kulturressurs. Flere har ment at Ecuador har plikt til å bevare regnskogen fordi den er del av den globale karbonsirkelen. Mot dette står argumentet at Yasuni er én av flere naturressurser under nasjonal kontroll, noe som innebærer rett til suveren kontroll over egne ressurser. Samtidig er et viktig hovedargument at innbyggerne har rett til beskyttelse mot risker av ulike slag: framtidig klima, økonomisk utarming, og krenkelse av urbefolkningens rettigheter.

(2) Skal ansvaret fordeles ut fra evne, behov eller prinsippet om fri og utbyttbar handel?

Dette angår helt grunnleggende spørsmål om et globalt rettferdighetsperspektiv, noe som allerede ligger implisitt i den globale 
allmenningen. Det viktigste særpreget er at reguleringer og inngrep ikke kan avgrenses til mindre nasjonale eller lokale områder. Det som skjer med regnskogen i Ecuador har konsekvenser globalt. Fattige land som er rike på naturressurser støtter seg på argumentet at det ikke er de selv som er skyld i problemet med f.eks. $\mathrm{CO}_{2}$ utslipp dersom de ikke får internasjonal hjelp til å kompensere for tapet av uutnyttede ressurser.

Her er det to typer appell til rettferdighet: For det første at Ecuador ikke har økonomisk evne til å håndtere problemet selv, og for det andre at det er rimelig at de får bestemme over egne naturressurser selv. Men fordi de ikke har økonomisk evne til å bære kostnadene ved å avstå fra å utnytte egne ressurser for seg selv, er det rimelig at det internasjonale samfunnet også bidrar.

(3) Skal de som har bidratt mest til klimaproblemet også holdes mest ansvarlig for å minske problemet?

For å unngå en uendelig sirkel av argumenter er det nødvendig å holde fast ved hva som følger av de grunnleggende prinsippene vi har lagt til grunn ovenfor. Allmenninger er ikke som andre varer; menneskelig utnyttelse av allmenninger som Yasuni har global rekkevidde; føre var-prinsippet tilsier at vi ikke bør ødelegge regnskogen ved oljeboring fordi vi vil ødelegge en global ressurs som tilhører det globale fellesskapet. Men hva følger av dette resonnementet? Yasuni kan ikke både være en ressurs som ensidig forvaltes av Ecuador alene, og samtidig tilhøre menneskeheten globalt. Hele tankegangen om skillet mellom lokalt, nasjonalt og globalt forvaltningsnivå (governance) fungerer med andre ord dårlig når vi diskuterer etiske argumenter og legitimitet for allmenninger.

Selv om vi blir enig om prinsipper for fordeling av kostnader og ansvar mellom Ecuador og det internasjonale samfunnet, gjenstår fortsatt spørsmålet om fordelingen skal baseres på matematiske kalkyler for hvem som bidrar mest med naturressurser og hvem som bidrar mest til store fotavtrykk. Vi ser uten videre at kabalen ikke går opp ut fra en slik tenkemåte: Oljen slumper til å befinne seg under Yusani, og det er ingens fortjeneste at den ligger der - på liknende vis som store fotavtrykk og mer forurensning naturlig følger 
av livsstilen, kulturen og infrastrukturen som gjelder der mennesker slumper til å leve. ${ }^{5}$ På liknende vis som Ecuador eier ressurser det er problematisk å utnytte, har fiskerne som driver overfiske og forurenser i Sør-Kinahavet i realiteten få valgmuligheter dersom valget står mellom overlevelse eller beskyttelse av miljøet.

\section{Guangdong, Yasuni og utmarka}

Her skal vi se at argumenter og prinsipper som gjelder for allmenninger som regnskog og fiske i havet, også gjelder for utmarka. Det er fordi alle tre - havet og fisken i havet rundt Guangdong, regnskogen med underliggende olje i Yasuni og utmarka i Norge - er eksempler på allmenninger som trenger bærekraftig forvaltning. Regulering av bruken må ta hensyn at de er knappe og ikke-fornybare ressurser som må fordeles rettferdig. For noen allmenninger, som den norske utmarka, gjelder det avveiningen mellom ulike interessenter og hensynet til fremtidige generasjoner. Ut fra et sterkt bærekraftbegrep har vi imidlertid liknende forpliktelser å ivareta som Guangdong og Yasuni. Ikke-fornybare ressurser står på spill, og dersom vi både skal ha rettferdig forvaltning og unngå overforbruk har vi samme type etiske dilemma å håndtere: Hvordan skal vi sørge for bærekraftig forvaltning som både er rettferdig og opprettholder eiendomsforhold som passer for allmenningen? Hevdvunne rettigheter knyttet til fisken i havet er tuftet på samme etiske begrunnelse som hevdvunne rettigheter på land. Disse hevdvunne rettighetene utfordres av nye interessenter både lokalt og globalt. Derfor er det viktig å sammenlikne ulike allmenninger når begrunner rettferdig forvaltning av den norske utmarka.

Sammenlikningen med fløyta til Sen fungerer bare delvis for allmenninger: Noen har større behov og noen har bedre evne, mens alle trenger tilgang, til forskjell fra eksemplet med fløyta. Tilgangen kan bare sikres dersom forvaltningen er rettferdig, dvs. at ingen særinteresser (lokale eller nasjonale) kan overstyre fellesskapets behov.

5 Kerri Woods (2015, s. 99) peker på at miljøforurensning ikke primært skyldes den enkeltes valg, men er et resultat av en livsstil, av millioner av menneskers ukoordinerte individuelle handlinger. 
I vår tid med covid-19 er det også interessant å se på mulige paralleller i argumentene for hvordan vi skal prioritere og fordele knappe goder. Når vaksiner er klare til bruk vil det ikke være nok til alle. Alle smittede har behov, men ikke alle behov kan dekkes. Mens vaksinen imidlertid kan fordeles individuelt, gjelder ikke det samme for tilgangen til knappe naturressurser, selv om prioriteringstanken likner et stykke på vei: For covid-19-vaksinen prioriterer man de som trenger det mest, altså etter behov, til forskjell fra betalingsevne. På liknende vis er allmenningen et gode som ikke er til salgs til høystbydende. Et liberalt eiendomsbegrep i Lockes forstand kan derfor ikke gjelde, fordi det åpner for en urettferdig fordeling av viktige fellesgoder.

\section{Rettferdighet innen og mellom generasjonene}

Rettferdighet er et omfattende etisk-filosofisk tema, men her begrenser vi oss til den konteksten som gjelder ikke-fornybare naturressurser som inkluderer mange allmenninger, ikke bare de globale (som Yasuni). Også norsk utmark er en allmenning i samme forstand: Den tilhører fellesskapet, og er noe som deles av et mangfold av ulike interessenter. At allmenninger eies av noen (privat eller offentlig) fritar ikke fra etiske forpliktelser knyttet til rettferdighet. Men hva slags rettferdighet er viktigst?

I faglitteraturen om rettferdighet knyttet til knappe, ikke-fornybare ressurser, er det særlig ett forhold som har fătt mye oppmerksomhet, nemlig intergenerasjonell rettferdighet. Dette er spørsmålet om hva vi skylder framtidige generasjoner. I Brundtland-rapporten Our Common Future (World Commission on Environment and Development, 1987, del 1) uttrykkes forpliktelsene overfor kommende generasjoner slik: «Sustainable development is development that meets the needs of the present without compromising the ability of future generations too meet their own needs.»

Det innebærer at vi må «spare» for framtidige generasjoner. John Rawls kaller dette «just savings», altså rettferdig sparing (Rawls, 1971, seksjon 44). Rettferdig sparing bygger på at vi har en plikt overfor våre etterkommere til å spare tilstrekkelig til å opprettholde stabile institusjoner over tid. Denne formen for gjensidighet (reciprocity) omfatter derfor 
et prinsipp om forhåndsbetaling («paying forward», Alvarez \& Thorseth, 2020; Meyer, 2008; Gosseries 2009)). En slik gjensidighet er imidlertid omstridt. De mest kritiske spør hvorfor vi skal ha større eller like store forpliktelser overfor framtidige mennesker som vi ikke kjenner (fordi de ikke er født ennå), på bekostning av forpliktelser overfor den nålevende generasjon?' Av samme grunn mener mange at vi først og fremst bør ha forpliktelser overfor de vi kjenner, noe som svekker heller enn styrker forpliktelsen overfor de som ikke inngår i vår nære krets. På ulike nivå kan det være egen familie, eget lokalsamfunn, egen nasjon, egen klasse osv.

Prinsippet om «framoverbetalende gjensidighet» virker høyst rimelig når vi snakker om allmenninger - til forskjell fra f.eks. personlig arv. Den viktigste grunnen er at allmenninger ikke er utbyttbare varer (commodities), de er nettopp allmenne (commons). Noen som arver en privat formue står fritt til å spare pengene, forbruke til eget formål eller donere til veldedige formål. Ingen av disse valgene truer i utgangspunktet våre felles ikke-fornybare ressurser. Når derimot korrupte statsledere behandler fattige lands rike og ikke-fornybare naturressurser som egen gevinst, trues både nålevende fattige og generasjonene etter oss. Ut fra samme resonnement er ikke den norske utmarka en vare som kan selges fritt, dvs. transaksjonen angår både nålevende og framtidige generasjoner. Det betyr at selv om privatpersoner eier slike allmenninger, kan ikke kjøp og salg skje ut fra egeninteresse alene.

Selv en liberal tenker som Locke mener at det fins begrensninger: man skal bare ta det man trenger, man skal ikke sløse med ressursene, og man skal sikre (i alle fall) eget avkom (Locke, 1690/2014, 2. T). For å sikre at allmenninger ikke svekkes, trenger vi imidlertid et sterkere vern enn en klassisk liberalistisk, antroposentrisk begrunnelse kan yte. For å sikre at allmenninger ikke ødelegges eller går tapt, er det nødvendig å supplere det antroposentriske perspektivet med et mer omfattende, for å sikre hele naturen. Da må vi også inkludere dyr og naturen/miljøet selv. For å sikre framtidige generasjoner har mange foreslått at vi trenger miljørettigheter (Boyle, 2007; Cullet, 1995). I likhet med framtidige generasjoner, dvs. de som ennå ikke er født, kan heller ikke naturen selv ha stemmerett.

6 Jf. ikke-identitetsproblemet (non-identity problem), Parfit, 1986. 
Miljørettigheter kan derfor ikke forstås som individuelle rettigheter på linje med menneskerettigheter. De må i stedet forstås som kollektive rettigheter, der kollektivet er summen av alt og alle som kan tenkes å bli berørt av endringer i utmarka. Det er med andre ord fellesskapets tilgang til fornybare naturressurser og naturmangfold som står på spill. Å sikre slike verdier for framtiden omfatter individuelle menneskerettigheter, men kan ikke reduseres til slike.

\section{Avsluttende bemerkninger}

Hvordan skal vi navigere, og hvilke etiske prinsipper bør gjelde for styring av utmarka? I andre kapitler i denne boka er endringer i utmarka belyst med mange konkrete eksempler - ny bruk for stadig flere grupper av befolkningen viser klart at utmarka er en begrenset ressurs. Ulike typer av interesser står mot hverandre. Beiteområder trues av ulike typer utbygging - vei til hyttefelt eller kraftutbygging. Behovet for økonomisk vekst står mot rekreasjons- eller verneinteresser. Opprinnelig bruk av utmarka, som skogsdrift, seterdrift, jakt, fangst og fiske konkurrerer med nye næringsinteresser. Høyesterett kan avgjøre i alle konkrete konflikter som kommer opp. Men vi trenger også en dypere etisk refleksjon over hvilke prinsipper og prioriteringer vi bør følge.

Vi står overfor mange verdikonflikter, hvorav noen er belyst ovenfor gjennom eksemplene med Sens fløyte, fiskerisamfunnet Guangdong i Sør-Kinahavet og Yasuni nasjonalpark i Ecuador. Gjennom en kort analyse av Lockes individbaserte liberalisme, basert på et antroposentrisk grunnsyn, har vi forsøkt å vise at vi trenger et sterkere vern for alle ikke-fornybare ressurser, inklusive allmenninger som utmarka. Det er fordi allmenninger ikke kan sammenliknes med varer på et marked, og forvaltningen kan derfor ikke styres av eiers særinteresser alene.

Ikke alle etiske prinsipper vi har diskutert er like enkle å forvalte. Føre var-prinsippet ber oss om å unngå vesentlig skade på natur og miljø, men vi kan jo ikke vite sikkert hva framtiden vil bringe - om f.eks. ny teknologi kan reparere skadet natur. Her har vi argumentert ut fra et begrep om sterk borekraft: økonomisk og miljømessig kapital er komplementære, men ikke utbyttbare. Vi kan ikke erstatte en tapt regnskog i bytte 
mot økonomisk kapital, jf. Yasuni-eksemplet omtalt ovenfor. Og ansvaret for framtidige generasjoner krever at vi må sørge for neste generasjons evne til å overdra ressursene til kommende generasjoner, jf. Brundtland-rapporten Vår felles framtid. Rapporten og ansvaret for framtidige generasjoner forutsetter et prinsipp om «framoverbetalende gjensidighet» (paying it forward). Vi har med andre ord ingen rett til å forbruke ikke-fornybare ressurser fordi vi enten eier et bestemt område, er født inn i en bestemt generasjon eller bor i et rikt land med demokratisk styresett. Sagt med andre ord har ikke fattige under korrupte styresett mindre rett til de samme ressursene, og framtidige mennesker som ennå ikke er født har ikke mindre rett enn nålevende. Det betyr at det er rettferdig at de som disponerer over allmenninger har en plikt til å sørge for bærekraftig forvaltning, til felleskapets beste.

\section{Referanser}

Alvarez, A. \& Thorseth, M. (2020). Intergenerational justice and obligations to future generations: Towards environmental rights and land use policy. I H. Bjørkhaug, P. McMichael \& B. Muirhead (Red.), Finance or food. The role of cultures, values, and ethics in land use negotiations (s. 243-270). University of Toronto Press.

Bailey, J. \& Thorseth, M. (2017). Value and growth - rethinking basic concepts in Lockean liberalism. Etikk i praksis, 11(1), 107-129. https://doi.org/10.5324/eip. v11i1.1967

Boyle, A. (1995). Human rights or environmental rights - a reassessment. Fordham Environmental Law Review, 18(3), 471-511.

Cullett, P. (1995). Definition of an environmental right in a human context. Netherlands Quarterly of Human Rights, 13(1), 25-40. https://doi.org/10.1177/ 016934419501300103

Dryzek, J. (1995). Political and ecological communication. Environmental Politics, 4(4), 13-3o. https://doi.org/10.108o/o9644019508414226

Ferraro, G. \& Bran, M. (2000). Trade-offs between environmental protection and economic development in China's fisheries policy: A political analysis in the adoption and implementation of the Fisheries Law. Natural Resources Forum, 36(1), 38-49. https://doi.org/10.1111/j.1477-8947.2012.01443.x

Gosseries, A. (2009). Three models of intergenerational reciprocity. I A. Gosseries \& L. H. Meyer (Red.), Intergenerational justice (s. 119-146). Oxford University Publishing.

Hamsun, K. (1917). Markens grøde. Gyldendalske Boghandel, Nordisk forlag. 
Hardin, G. (1968). The tragedy of the commons. Science, 162(3859), 1243-1248. https://doi.org/10.1126/science.162.3859.1243

Holland, A. (2000). Sustainability. I Routledge encyclopedia of philosophy. Taylor \& Francis. https://doi.org/10.4324/9780415249126-S100-1

Libell, S. P. (2011). The text and context of 'enough and as good': John Locke as the foundation of an environmental liberalism. Polity, 43(2), 210-241. https://doi.org/ $10.1057 /$ pol.2010.28

Locke, J. (2014). Second treatise of government. Project Gutenberg Ebook. Hentet 15. mars 2015 fra http://www.gutenberg.ofg/files/737o/7370-h/7370-h.htm (Opprinnelig utgitt 1690)

Meyer, L. (2008). Intergenerational justice. http://plato.stanford.edu/entries/justiceintergenerational

Ostrom, E. (2015). Governing the commons: The evolution for collective action. Cambridge University Press. (Opprinnelig utgitt 1990)

Parfit, D. (1986). Reasons and persons. Oxford University Press.

Rawls, J. (1971). A theory of justice. Cambridge University Press.

Sen, A. (2009). The idea of justice. Harvard University Press.

Thorseth, M. (2015). Limitations to democratic governance of natural resources. I D. Birnbacher \& M. Thorseth (Red.), The politics of sustainability: Philosophical perspectives (s. 36-53). Routledge Earthscan.

Thorseth, M. \& Schuppert, F. (2018). Governance towards a green future.

I M. Düwell, G. Bos \& N. van Steenbergen (Red.), Towards the ethics of a green future. The theory and practice of human rights for future people (s. 167-190). Routledge.

Utmark. (2021, 26. februar). I Store norske leksikon. https://snl.no/utmark Woods, K. (2015). Climate justice, motivation and harm. I D. Birnbacher \& M. Thorseth (Red.), The politics of sustainability: Philosophical perspectives (s. 92-109). Routledge Earthscan.

World Commission on Environment and Development. (1987). Report of the World Commission on Environment and Development: Our common future (Rapport). http://www.un-documents.net/wced-ocf.htm 


\section{Bidragsytarar}

Tor Arnesen, forskar ved Høgskulen i Innlandet

Katrina M. Brown, forskar ved The James Hutton Institute

Svein Morten Eilertsen, forskar ved Norsk institutt for bioøkonomi (NIBIO)

Knut Fageraas, fyrstekonservator ved MiA - Musea i Akershus

Frode Flemsæter, seniorforskar ved Ruralis - Institutt for rural og regionalforsking

Bjørn Egil Flø, seniorforskar ved Norsk institutt for bioøkonomi (NIBIO)

Katrine Broch Hauge, fyrsteamanuensis ved Universitetet i Oslo

Bernt Johansen, seniorforskar ved NORCE Norwegian Research Centre

Stine Kvamme, forskar ved Høgskulen i Innlandet

Jan Åge Riseth, sjefsforskar ved NORCE Norwegian Research Centre

May Thorseth, professor ved Noregs teknisk-naturvitskaplege universitet (NTNU)

Odd Inge Vistad, seniorforskar ved Norsk institutt for naturforsking (NINA)

Jørund Aasetre, fyrsteamanuensis ved Noregs teknisk-naturvitskaplege universitet (NTNU) 
